SÉRGIO DE SOUZA GABRIEL

\title{
ENSINANDO O FUTURO NO ENSINO MÉDIO: UMA INVESTIGAÇÃO
}




\section{SÉRGIO DE SOUZA GABRIEL}

\section{ENSINANDO O FUTURO NO ENSINO MÉDIO: UMA INVESTIGAÇÃO}

Tese apresentada à Escola de Comunicações e Artes da Universidade de São Paulo, para obtenção do título de Doutor junto ao programa de Ciências da Comunicação - Área de Concentração: Interfaces Sociais da Comunicação.

Orientador: Prof. Dr. Fredric Michael Litto

São Paulo 
Banca Examinadora: 
A mudança é uma das leis da vida. E aqueles que se prendem somente ao passado e ao presente certamente perderão o futuro.

John F. Kennedy 


\section{AGRADECIMENTOS}

Ao Professor Litto, pela orientação prestada no desenvolvimento deste trabalho, pelo acesso à sua biblioteca e pela inesgotável fonte de inspiração.

A Richard Slaughter e David Hicks, pela generosidade na colaboração com essa pesquisa e pelo empréstimo de diversos de seus trabalhos, mesmo através de oceanos e continentes.

Às diretorias e coordenações das escolas que serviram como fonte de dados para a execução desta pesquisa e, em especial, à Professora Cinília, cuja partida prematura não impediu que ela deixasse as sementes do futuro junto a seus alunos.

Aos professores participantes da pesquisa, cujo compromisso com o trabalho de preparar e educar jovens ainda é uma de nossas maiores garantias de futuro.

À minha família, sempre presente no seu carinho e apoio.

A todos os colegas e amigos pelo apoio e incentivo constantes, e pelo auxílio inestimável nessa jornada.

A Paulo Amaral Gonçalves, por provar que não existe futuro tecnológico que seja páreo para o espírito humano. 
GABRIEL, Sérgio de Souza. Ensinando o Futuro no Ensino Médio; Uma Investigação.

São Paulo, 2008.

Tese (Doutorado) - Escola de Comunicações e Artes, Universidade de São Paulo.

RESUMO: Descreve uma investigação realizada junto a professores do Ensino Médio sobre percepções relacionadas à inovação curriculares na forma de estudos do futuro.

Objetivo: Em primeiro lugar, identificar de que maneira os professores entendem o conceito de "futuro" em suas vidas. Em segundo lugar, identificar percepções e atitudes em relação aos estudos do futuro e à implementação destes junto a alunos do Ensino Médio da cidade de São Paulo. Em terceiro, orientar projetos nas escolas locais que adotassem essa abordagem. Método: Em sua primeira fase, questionário estruturado enviado a 200 professores participantes, no período de março a junho de 2007. Em sua segunda fase, oficina de apresentação realizada nas escolas investigadas e outro questionário estruturado enviado a 80 professores, no período de junho a agosto de 2007. Em sua terceira fase, reuniões com professores e coordenadores das escolas adotantes. Resultados: A primeira fase mostrou que os professores percebem o futuro como um período de tempo entre 10 a 20 anos do presente. Existe uma mistura de otimismo e preocupação em relação ao futuro e a crença de que é necessário um alto grau de preparação para este. A segunda fase mostrou que os professores percebem a relevância em estudar o futuro, principalmente para si mesmos. Entre as ferramentas apresentadas na oficina, técnicas como elaboração de cenários e consulta a especialistas lhes pareceram mais claras e de maior facilidade e relevância para a introdução junto a seus alunos. A terceira fase incluiu a adoção projetos multidisciplinares, propostas curriculares e atividades isoladas, por parte de algumas das escolas. Conclusão: Os professores mostram um grau de preocupação e interesse elevado na preparação de seus alunos para o futuro. Os estudos do futuro oferecem uma alternativa viável para a introdução de projetos e atividades de caráter multidisciplinar que ajudam os jovens a planejar e se preparar para o futuro.

Descritores: estudos do futuro; ensino médio; inovação curricular; projetos multidisciplinares; temas transversais 
GABRIEL, Sérgio de Souza. Ensinando o Futuro no Ensino Médio; Uma Investigação. São Paulo, 2008.

Tese (Doutorado) - Escola de Comunicações e Artes, Universidade de São Paulo.

ABSTRACT: It describes an investigation carried out with Secondary School teachers on their perceptions regarding curriculum innovations using a futures studies approach.

Aim: Firstly, to identify the ways in which teachers view the concept of "future" in their lives. Secondly, identify the perceptions and attitudes regarding futures studies and their introduction in the Secondary School classroom in the city of São Paulo. Thirdly, supervise projects in the local schools which adopted such approach. Methodology: In its first phase, a structured questionnaire was sent to the 200 participant teachers, between March and June 2007. In its second phase, a workshop to introduce future studies in the schools under investigation was held, followed by another structured questionnaire, between June and August 2007. In its third phase, meetings with teachers and pedagogical coordinators were held. Results: The first phase showed teachers perceive the future as a period between 10 and 20 years from the present. There is a mix of optimism and worry and a belief that a high level of preparation is required for this future. The second phase showed that teachers perceive the relevance of future studies, particularly for themselves. Among the tools presented in the workshop, the creation of scenarios and the use of expert opinion were those which seemed clearer, more relevant and of easier introduction in the classroom. The third phase included the adoption of cross curricular projects, proposals for curriculum change and attempts at different activities by some of the schools. Conclusion: Teachers show a high level of interest and worry in the preparation of their students for the future. Future studies offer a viable alternative for the introduction of projects and classroom activities of a cross curricular nature that will help young people to plan and prepare for the future.

Key words: Future studies. Secondary School. Curriculum Innovation. Cross curricular projects. Education for citizenship. 


\section{SUMÁRIO}

RESUMO

ABSTRACT

\section{INTRODUÇÃO}

$1.1 \quad$ Necessidade Do Estudo......................................................

1.2 Propósito Do Estudo...........................................................

1.3 Desenho E Abrangência Do Estudo.................................... 4

1.4 Importância Do Estudo.............................................................

1.5 Delimitação Do Estudo........................................................

2. HISTÓRICO E NATUREZA DOS ESTUDOS DO FUTURO

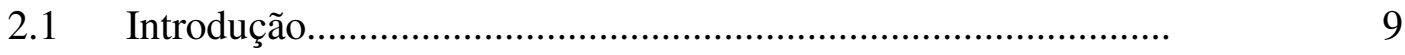

2.2 Estudos Do Futuro- Um Panorama Histórico............................... 10

2.3 Desenvolvimento Dos Estudos Do Futuro A Partir De 1945...... 14

2.4 Termos Utilizados E Seu Significado........................................ 21

2.5 Estudos Do Futuro E Seu Objeto De Estudo........................... 23

2.6 Estudos Do Futuro: Qual Futuro?.............................................. 27

2.7 Ferramentas Para O Estudo Do Futuro..................................... 32

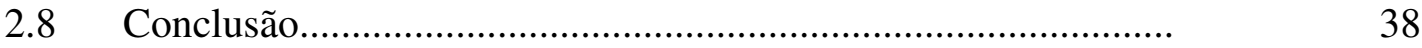

3. INOVAÇÃO CURRICULAR NA EDUCAÇÃO BRASILEIRA

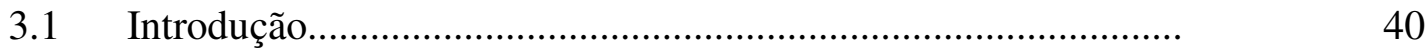

3.2 Da Natureza Da Educação E Seus Processos.............................. 41

3.3 O Brasil Colonial................................................................... 43

3.4 O Brasil Imperial......................................................................

3.5 Da Primeira República Ao Estado Novo....................................... 49

3.6 O Estado Novo E A República Populista..................................... 56

3.7 O Golpe Militar E Os Últimos Anos Do Século XX....................... 62

3.8 O Momento Atual E A Questão Da Inovação Curricular.............. 68

3.9 Agentes E Modelos De Inovação Curricular................................ 72

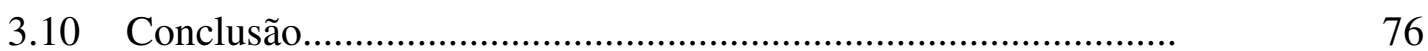




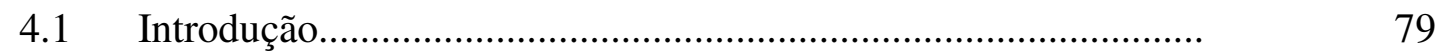

4.2 A Universidade E O Ensino Do Futuro....................................... 81

4.3 Ensinando O Futuro Para Crianças E Jovens: Por Quê?............. 87

4.4 Ensinando O Futuro Para Crianças E Jovens:Como?................. 93

4.5 Ensinando O Futuro Para Crianças E Jovens: Ferramentas........ 98

4.6 Por Uma Psicologia Do Futuro?................................................... 102

4.7 Conclusão........................................................................ 105

\section{ENSINANDO O FUTURO}

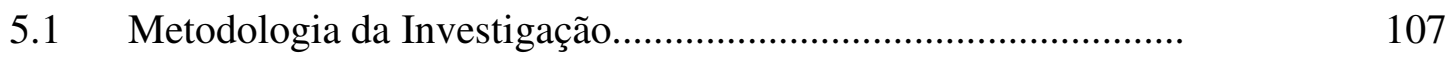

5.2 Atitudes Dos Professores Em Relação Às Questões do Futuro: Instrumento de Pesquisa.

5.3 Apresentando Os Estudos do Futuro Para Os Professores Do Ensino Médio......................................................................... 122

5.4 Identificando As Percepções Dos Professores Do Ensino Médio Em Relação Aos Estudos Do Futuro:Instrumento de Pesquisa ................................................................................ 131

5.5 Acompanhando A Implementação De Projetos Envolvendo Os Estudos Do Futuro Nas Escolas: Coleta De Dados.

\section{DESCRIÇÃO DA INVESTIGAÇÃO E RESULTADOS}

6.1 Contato Com Diferentes Estabelecimentos De Ensino Médio na Cidade de São Paulo.

6.2 Distribuição De Questionários E Coleta De Dados...................... 139

6.2.1 Resultados Do $1^{\circ}$ Questionário.................................................. 140

6.2.2 Respondentes....................................................................... 142

6.2.3 Discussão Dos Resultados Do $1^{\circ}$ Questionário............................. 147 
6.3 Realização Das Oficinas Para Apresentação Dos Estudos Do Futuro Nas Escolas: Coleta De Dados Adicionais.................. 175

6.3.1 Resultados Do 2 ${ }^{\circ}$ Questionário.................................................. 177

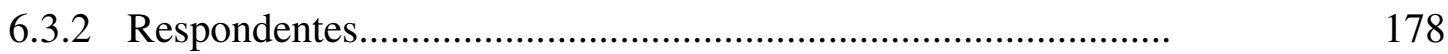

6.3.3 Discussão Dos Resultados Do $2^{\circ}$ Questionário........................... 182

6.4 Acompanhando A Implementação De Projetos Envolvendo Os Estudos Do Futuro Nas Escolas - Discussão Dos Resultados....

7. CONCLUSÕES E RECOMENDAÇÕES 199

REFERÊNCIAS BIBLIOGRÁFICAS

BIBLIOGRAFIA ADICIONAL

ANEXOS 


\section{LISTA DE TABELAS}

Tabela 1 - Mudanças nas Estrutura Curricular do Ensino Brasileiro (1)... 55

Tabela 2 - Mudanças na Estrutura Curricular do Ensino Brasileiro (2).....

Tabela 3 - Quadro com a organização dos diferentes tipos de estudos do futuro sugerido por Gidley................................................... $\quad 97$

Tabela 4- Questionário usado na $1^{\mathrm{a}}$ fase da investigação (página 1)...... $\quad 120$

Tabela 5 - Questionário usado na $1^{\mathrm{a}}$ fase da investigação (página 2)...... 121

Tabela 6 - Plano de Apresentação da Oficina.......................................... 125

Tabela 7 - Material utilizado na apresentação da oficina ( $1^{\mathrm{a}}$ parte).......... 126

Tabela 8 - Material utilizado na apresentação da oficina (2 $2^{\mathrm{a}}$ parte).......... 127

Tabela 9 - Material utilizado na apresentação da oficina ( $3^{\mathrm{a}}$ parte).......... 128

Tabela 10 - Material utilizado na apresentação da oficina (4 ${ }^{\mathrm{a}}$ parte)........ 129

Tabela 11 - Material utilizado na apresentação da oficina ( $5^{\mathrm{a}}$ parte)......... 130

Tabela 12 - Questionário usado na $2^{\mathrm{a}}$ fase da investigação...................... 134

Tabela 13 - Distribuição por Instituição.................................................... 144

Tabela 14 - Distribuição Demográfica..................................................... 145

Tabela 15 - “Ao ouvir a palavra 'futuro', você pensa aproximadamente em... ?"..........................................................................

Tabela 16 - "Com que frequiência você pensa em como sua vida será daqui...?".......................................................................... 151

Tabela 17 - "Qual seu grau de preocupação com sua vida daqui a...?”..... 153

Tabela 18 - "Com que clareza consegue visualizar o futuro daqui a... ?”... 155

Tabela 19- "Como se sente com relação ao futuro daqui a ... ?"................ 157

Tabela 20- "Qual deveria ser o grau de preparação ativa da humanidade para o futuro daqui a....?"..................................................... 159

Tabela 21- "Como julgaria o grau de responsabilidade atual da humanidade no que diz respeito a questões futuras como...?".

Tabela 22- "Na sua opinião, qual o grau de preparação dos jovens em idade escolar para lidar com essas questões do futuro?"

Tabela 23- "Na sua opinião, a educação escolar oferece essa preparação aos jovens para lidar com questões do futuro?". 
Tabela 24- Por favor, indique o seu grau de concordância ou discordância das afirmações abaixo:

Tabela 25- "Caso pudesse nascer no futuro, indique quando gostaria de nascer: daqui a

Tabela 26- "Acredita que a humanidade um dia se extinguirá?” (\%).......

Tabela 27- "Quando a humanidade se extinguirá?".

Tabela 28- "Por que a humanidade se extinguirá?"

(Assinale uma ou mais respostas)

Tabela 29- Distribuição por Instituição

Tabela 30- Distribuição Demográfica da Amostra

Tabela 31- 'Em relação à natureza dos 'estudos do futuro', posso dizer que... ?"

Tabela 32- 'Em relação à relevância dos 'estudos do futuro' posso dizer que são:... ?"

Tabela 33- "Baseado na apresentação, em relação aos conceitos envolvidos nos estudos do futuro, posso dizer que:... ?".......

Tabela 34- "Baseado na apresentação, em relação ao aprendizado dos conceitos envolvidos nos estudos do futuro, posso dizer que meus alunos:.... ?"

Tabela 35- "Como vê a relevância do aprendizado das seguintes habilidades por parte dos alunos do ensino médio?"

Tabela 36- "Como vê o interesse pelo aprendizado das seguintes habilidades por parte dos alunos do ensino médio?"

Tabela 37- "Como julgaria o grau de dificuldade na introdução das seguintes atividades relacionadas aos estudos do futuro junto aos alunos do ensino médio?”.

Tabela 38- "Na sua opinião, qual o grau de preparação dos alunos do ensino médio para lidar com as seguintes áreas de interesse relacionadas aos estudos do futuro?". 


\section{INTRODUÇÃO}

\subsection{NECESSIDADE DO ESTUDO}

Poucos negariam a importância do estudo do passado do homem como ferramenta necessária para a compreensão da sua história e, por conseqüência, da importância desta na compreensão do momento atual, já que tal estudo provavelmente facilitaria o desenvolvimento e o conhecimento da própria humanidade. No entanto, as razões de tal estudo provavelmente não se resumem a isso. O que talvez esteja implícito nesse estudo do passado (e conseqüentemente, do presente) é igualmente uma necessidade de se entender o futuro. Afinal, é perfeitamente aceitável que atitudes conscientes ou inconscientes em relação ao futuro tenham influenciado grupos humanos e suas ações por toda a história, e certamente com diferentes conseqüências. Assim, estudar o futuro torna-se também necessário para se compreender a dimensão histórica do futuro e do que ele poderá trazer. Esta é uma necessidade que vem aumentando consideravelmente, e parece ficar especialmente evidente na educação, já que essas imagens do futuro, aceitas por educadores e passadas a seus alunos podem dar forma às atitudes e percepções destes em relação ao futuro. (Norris, 1983)

A segunda metade do século 20 e os primeiros anos do século 21 mostram uma taxa de mudança cada vez mais acelerada, onde diversos problemas de complexidade e magnitude crescentes convergem cada vez mais, exemplificando aquilo que o sociólogo francês Raymond Aron chamou de 'mutação histórica': segundo ele, após o período das duas grandes guerras (1914-1945), as civilizações industriais mais avançadas vivenciaram a mesma história pela primeira vez, causando o nascimento da "história universal" (Aron, 1961). Tal convergência mostra-se ainda mais acentuada com o fim dos 'blocos de poder' (EUA e URSS) que dominaram a política mundial na segunda metade do século $X X$, o que resultou num modelo econômico de desenvolvimento mais semelhante adotado entre as diversas nações do planeta. 
Essa aceleração de mudanças, segundo alguns futuristas, parece crescer em ritmo exponencial (particularmente na capacidade do homem em afetar seu meio-ambiente) e acentuar os efeitos daquilo comumente descrito como 'globalização': interdependência global, um histórico e um destino comuns, e estruturas sociais globais. Mais do que isso, ele aproxima as sociedades industriais de uma encruzilhada onde as estas crescentes pressões colocam em xeque a viabilidade de instituições e valores ${ }^{1}$.

Essa situação onde poucos indivíduos ou nações podem realmente se isolar dos efeitos globais difere de períodos históricos anteriores e assim, nos parece ainda mais imperativo que as questões relacionadas ao futuro ganhem um espaço ainda maior em diversos setores da sociedade. Um setor da sociedade onde a discussão do futuro pareceria encontrar sua aplicação mais lógica seria o da educação, uma vez que as futuras gerações seriam as maiores beneficiadas por algum tipo de ação voltada à preservação de seu futuro. $\mathrm{Na}$ verdade, desde a segunda metade do século passado, diversos observadores de diferentes áreas de conhecimento já vêm indicando a necessidade de se estudar o futuro nas escolas. (Marien, 1973)

Em sua história, a educação brasileira reflete as diversas mudanças ocorridas na formação brasileira atual, percorrendo uma longa jornada desde seu berço colonial. Considerando-se somente o século $\mathrm{XX}$, palco dessa aceleração histórica mencionada anteriormente, poderemos notar que a estrutura do ensino brasileiro procurou se adaptar às necessidades sociais da nação emergente (Piletti, 2006). No entanto, tais re-estruturações apontam para a formação de cidadãos atuantes no futuro, mas, em sua estrutura curricular, partem da premissa que o paradigma passado-presente seja suficiente para a educação desses mesmos jovens em relação a esse futuro, ou seja, não parecem explicitar conteúdo ou abordagem diretamente voltados às necessidades do futuro do país

\footnotetext{
Vários historiadores discutem a questão da globalização da história, em particular L. S. Stavrianos e Lee Anderson. Ver Stavrianos L. S. The World Since 1500; A Global History. Englewood Cliffs, Prentice Hall, NJ 1971, Stavrianos L. S. The Promise of the Coming of the Dark Age San Francisco Wilt Freeman \& Co. 1976 e Anderson, Lee Schooling and Citizenship in a Global Age: An Exploration of the Meaning and of the Significance of Global Education, Bloomington: Social Studies Development Center, 1979)
} 
ou dos alunos.

Por um lado, não seria difícil afirmar que, de uma forma ou de outra, nossos educadores ajudem a moldar a percepção dos alunos em relação ao futuro, quer estas sejam abordadas de maneira explícita ou não dentro de sua prática diária. Por outro lado, existe pouca evidência se essa questão do futuro é abordada, explícita ou implicitamente nas escolas e, em caso afirmativo, quais seriam as metodologias usadas nessa abordagem.

Por que introduzir tal abordagem explicitamente então? Norris (p.5) acredita que:

(...)o futurismo fornece uma perspectiva e um número de ferramentas para a solução de problemas que podem ajudar a esclarecer e resolver diversos dilemas sociais. Introduzir o futurismo nas escolas pode também ajudar a diminuir uma necessidade pedagógica básica, mas há muito negligenciada, que todo profissional da educação tem de enfrentar: as atitudes e premissas controladoras que este traz a seu trabalho.... a visão do futuro que o educador adota deveria ser explicitamente reconhecida como um aspecto fundamental de sua visão de mundo. Como tal, deveria ser cuidadosamente explorada para revelar o papel que ela desempenha na determinação de suas atitudes e percepções.

Assim, o autor também acredita que a educação brasileira poderia aprender com a introdução de abordagens mais explícitas voltadas ao ensino do futuro. Ela poderia representar uma inovação na prática diária do professor sem prejuízo do sistema ao qual ele pertence. Poderia também se transformar em um instrumento para o próprio professor melhor compreender suas próprias atitudes e percepções em relação ao futuro e, gradativamente, transformar sua prática profissional, quebrando o paradigma passado-presente existente na visão histórica que é passada aos alunos. Por fim, 'não é missão da educação preparar os alunos agora para viver num contexto futuro, pensando não apenas nas suas vidas pessoais e profissionais, assim como nas sociedades em que pretendem viver?' (Litto in Siqueira, 2005, p.218)

\subsection{PROPÓSITO DO ESTUDO}

Este estudo irá explorar o papel do 'futuro' na educação brasileira de 
Ensino Médio, uma vez que aprender sobre futuros alternativos nos parece essencial para uma compreensão significativa do desenvolvimento do indivíduo e da sociedade. Portanto, acreditamos que o estudo do futuro deveria tornar-se uma parte cada vez mais explícita do nosso sistema educacional.

O propósito deste estudo é o de investigar as atitudes e percepções dos professores de Ensino Médio em relação ao futuro e aos estudos do futuro. A partir daí, possivelmente orientar atividades para a introdução de abordagens relacionadas aos estudos do futuro nas escolas. A investigação das atitudes e percepções em relação ao futuro e ao estudo deste se dará principalmente através da análise de resultados obtidos através da distribuição de questionários em diferentes instituições. Em seguida, a sugestão de atividades relevantes se dará a partir de um processo de inovação curricular, visando um grau de flexibilidade em sua adoção, de maneira que este se adapte aos conteúdos, necessidades e interesses de alunos e professores.

\subsection{DESENHO E ABRANGÊNCIA DO ESTUDO}

Três perguntas fornecerão as direções gerais para este estudo:

1- Quais seriam, de maneira genérica, as atitudes e percepções dos educadores do Ensino Médio brasileiro em relação ao futuro?

2- $\quad$ Uma vez mais familiarizados com abordagens explícitas para os estudos do futuro, os professores, a partir de suas necessidades, reconheceriam a relevância destas e escolheriam as maneiras mais eficazes para introduzir esse estudo de futuros alternativos na estrutura de Ensino Médio brasileira?

3- Quais as mudanças que poderiam ocorrer na percepção de professores e alunos caso uma abordagem relacionada aos estudos do futuro fosse introduzida em sua prática diária? 
Este estudo foi desenhado para encontrar respostas a estas perguntas através de três objetivos correspondentes:

1. Investigar o papel das questões do futuro (e do estudo deste) nas atitudes e percepções dos professores de Ensino Médio e como estas podem moldar sua atuação;

2. Explorar, junto aos professores, as abordagens utilizadas nos estudos do futuro de modo a oferecer a professores modelos de introdução destes estudos através de atividades em sala de aula, onde os alunos encontrem oportunidades significativas para a adoção destes estudos;

3. Avaliar os efeitos possíveis da introdução (ou não) dos estudos do futuro junto aos professores e alunos através do acompanhamento de projetos que utilizem a abordagem ou da detecção de causas e condições refratárias à adoção de tais abordagens.

Este estudo é baseado em informações obtidas (1) na análise da literatura voltada aos estudos do futuro, dentro de um panorama da evolução histórica destes como disciplina; (2) na análise da literatura referente à implementação de programas educacionais voltados aos estudos do futuro, tanto do ponto de vista da formação de professores como de experimentos realizados nessa área junto a alunos; (3) na análise histórica do ensino brasileiro dentro de uma perspectiva de experimentação e inovação curricular; (4) nas informações qualitativas e quantitativas provenientes de questionários aplicados junto a professores e alunos participantes das diferentes fases do estudo.

Este estudo procura equilibrar a análise da literatura específica com os dados obtidos pelos questionários, no intuito de revelar de que forma a percepção e as atitudes dos professores em relação ao futuro e ao estudo deste podem interferir na introdução de estudos do futuro no Ensino Médio de uma forma especulativa, oferecendo subsídios para futuros trabalhos. Portanto, a 
abrangência deste estudo fica demonstrada através da dedicação de capítulos separados para cada uma de suas áreas de investigação. O Capítulo 2 conterá então uma análise da literatura voltada aos estudos do futuro, dentro de um panorama histórico e de seu surgimento como disciplina específica. O Capítulo 3 fará uma análise da educação brasileira e os processos de mudança curricular ocorridos, sob a ótica de experimentação e inovação curricular. O Capítulo 4 discutirá de que maneiras tais estudos do futuro vêm sendo adotados em diversos países e apresentará ferramentas para a introdução destes junto a alunos de ensino médio.

O Capítulo 5 fornecerá o desenho detalhado das diferentes fases do estudo, justificando o uso das metodologias adotadas dentro dessa perspectiva de investigação e inovação. O Capítulo 6 incluirá a discussão dos resultados obtidos na nas diferentes fases da pesquisa. Conclusões e recomendações constituem o conteúdo do Capítulo 7 e, porventura, este será seguido de uma seção com Anexos, que incluirá o relato da aplicação dos conteúdos apresentados em projetos e atividades desenvolvidos por professores e alunos.

\subsection{IMPORTÂNCIA DO ESTUDO}

A importância deste estudo reside especialmente na investigação das atitudes e percepções dos professores em relação aos estudos do futuro e na experimentação com diferentes atividades para a introdução destes estudos no Ensino Médio brasileiro. As evidências disponíveis indicam que esta é a primeira tentativa específica de investigação das atitudes dos professores em relação ao futuro e aos estudos do futuro, e também de introdução de práticas educacionais explícitas relacionadas a estes estudos no Ensino Médio brasileiro. Ela poderá fornecer o apoio prático e teórico necessário para que outros educadores possam 
mudar a orientação existente em seus programas. Por conseqüência, este estudo também poderá fornecer elementos para a reflexão relativa à novas abordagens em aspectos relacionados à organização, instrução e administração da educação brasileira atual.

Através da reflexão resultante das etapas do estudo, educadores podem re-examinar suas percepções e atitudes, buscando soluções que levem a um novo conceito na organização de conteúdos (o futuro) e por fim, à revisão de conteúdos ou à criação de novos materiais instrucionais. Os futuristas podem se valer da discussão dos resultados para alimentar o debate sobre a abrangência e as perspectivas desta área de estudo. Mais importante, no entanto, é a criação de uma base para discussão em âmbito brasileiro das questões voltadas ao papel do futurismo na educação brasileira.

\subsection{DELIMITAÇÃO DO ESTUDO}

A abrangência deste estudo tem de ser limitada de modo fundamental. Embora inclua a investigação junto a professores do Ensino Médio, as questões relativas à amostragem sugerem que o resultado dos questionários irá representar as percepções e atitudes de um grupo de professores de Ensino Médio atuando em diferentes escolas. Certamente, uma pesquisa mais abrangente dessas percepções e atitudes envolveria um número maior de participantes. No entanto, os resultados obtidos nesta investigação servem para revelar quais as percepções e dificuldades encontradas para a introdução dos estudos do futuro por parte do grupo de professores investigados. Portanto, os diferentes grupos a serem investigados poderão fornecer outros critérios para o escopo e conteúdos existentes nas atividades sugeridas, sendo que ambos, em si, deverão ser adaptáveis e flexíveis às necessidades dos professores, dos alunos e das instituições que adotem tais atividades.

Uma outra perspectiva (talvez preferível) seria a de criação de um currículo cuja organização como um todo refletisse o estudo do futuro em todas as áreas 
de educação. No entanto, são muitas as dificuldades de natureza prática envolvidas, sejam elas as restrições impostas pelo sistema escolar brasileiro em relação a uma alteração curricular; a formação pregressa de professores para aplicação de tal currículo (o que em si já é um dos focos de investigação deste estudo), a disponibilidade dos alunos para um curso 'em separado' dentro de suas cargas horárias atuais. Como uma estrutura curricular convencional será utilizada, a 'futurização' das áreas existentes de conteúdo seria preferível às opções do curso em separado ou de uma mudança estrutural de maior porte.

O estudo também se concentra no Ensino Médio, ao invés do ensino Fundamental ou Superior. Isso não implica em nenhuma visão do valor destes ou de quaisquer outros setores de educação. Na verdade, muito já foi dito em relação à importância da introdução destes estudos do futuro nos graus mais elementares e alguns programas são comumente encontrados no nível superior. Coincidentemente, boa parte das pesquisas já efetuadas concentra-se nos níveis secundários e terciários de educação, o que permite a legitimação das referências relacionadas ao desenho do modelo e de sua estrutura. 


\section{HISTÓRICO E NATUREZA DOS ESTUDOS DO FUTURO}

\subsection{INTRODUÇÃO}

Toda a educação surge a partir de alguma imagem do futuro. Se a imagem do futuro visado por uma sociedade for imprecisa em excesso, seu sistema educacional trairá seus jovens. (Toffler, 1974, p.3)

Este capítulo serve vários propósitos dentro deste estudo. Em sua primeira parte, ele discute algumas das noções relacionadas à palavra futuro procurando mostrar que o futuro tem sido constante objeto de interesse e preocupação do homem. Deste ponto de partida, a segunda parte do capítulo passa a atender uma necessidade inicial de melhor compreensão das informações relativas ao desenvolvimento do campo dos estudos do futuro dentro de um panorama histórico; mostrando que, no século $X X$, o desenvolvimento de processos oriundos de diferentes ciências sociais propiciaram o surgimento tanto de uma disciplina específica como o de profissionais que, fazendo uso de diferentes metodologias, promoveram e difundiram uma sistematização maior para que o futuro pudesse ser "estudado".

Em sua terceira parte, ele aborda e discute as diferentes denominações dadas a esses estudos e a seus profissionais, cuja diversidade é freqüentemente resultado da evolução desse campo de estudo e das diferentes abordagens utilizadas para tais estudos. Além de complementar o panorama histórico exposto nas primeiras duas partes do capítulo, esta abordagem e discussão servirão para a construção de um pequeno glossário, que tem o intuito de simplificar e sistematizar o uso dos termos escolhidos para este trabalho.

Em sua quarta parte, passamos a uma discussão mais detalhada do objeto de estudo dos estudos do futuro e de como este objeto afeta a percepção destes 
estudos como disciplina. A seção seguinte procura mostrar como a dicotomia "ciência ou arte?", forjada a partir da visão de futuro buscada pelos profissionais da área gerou um conjunto de abordagens relacionadas aos estudos do futuro que muitas vezes, é mesclada com outras atividades semelhantes, como o planejamento e a análise de políticas sociais ou empresariais. E, por fim, a seção final traz uma exposição mais detalhada das diferentes técnicas e ferramentas utilizadas para estudar o futuro adotadas pelos profissionais do setor, a despeito de suas visões em relação ao objeto de estudo em questão.

\subsection{ESTUDOS DO FUTURO - UM PANORAMA HISTÓRICO}

Antes de adentrarmos mais detalhadamente no panorama histórico dos estudos do futuro, cabe aqui uma observação em relação ao objeto de estudo desses estudos em si, o conceito de futuro. Com apenas uma breve pesquisa no dicionário Houaiss, obtemos a seguinte definição:

futuro $\square$ substantivo masculino;

1 tempo que se segue ao presente;

2 conjunto de fatos, acontecimentos relacionados a um tempo que há de vir;

3 existência futura;

4 destino; sorte

A própria acepção da palavra dá margens à interpretações de elementos causais (é o "tempo que se segue ao presente"), de elementos sistêmicos (o conjunto de fatos e acontecimentos relacionados a um tempo que há de vir"), da elaboração de conjecturas sobre esse período ("existência futura") e do acaso. Como pode então o futuro ser objeto de estudo uma vez que ele ainda não ocorreu? 
Uma rápida reflexão sobre o paradigma utilizado no estudo de fatos históricos poderia servir para responder a essa pergunta: como objeto de estudo, o registro de fatos históricos serve há séculos como fonte de referência (ainda que a confiabilidade de tais registros possa muitas vezes ser discutível como "objeto científico" de estudo, pois o passado, no caso, apesar de registrado, não é mais "observável", a não ser pela ótica daqueles que o registraram) no estabelecimento de relações causais, na descrição de elementos sistêmicos e na elaboração de conjecturas sobre esse período (ou seja, a "existência passada"). Nem mesmo os aspectos relacionados ao acaso (como por exemplo, catástrofes naturais) são por vezes descartados na compreensão de determinado fato histórico. De fato, dentro de uma visão histórica, poucos questionariam a relevância de estudar o passado para compreender o presente.

Não seria possível presumir então que o estudo desses mesmos elementos e relações serviria de alguma forma para compreendermos "um tempo que está por vir"? Considerando-se que determinados fatos e circunstâncias passadas "geraram" o momento presente, tais fatos e circunstâncias não apontariam para o "tempo que se segue ao presente"?

Entretanto, o futuro, por sua própria definição, ainda está por vir. E, como tal, parece ter sempre sido objeto de interesse (se não de estudo) do homem. $\mathrm{Na}$ realidade, não é difícil presumir que interesses individuais em relação ao futuro existam há milhares de anos. Diferente métodos de prever o destino de um indivíduo - desde a consulta à entranhas de animais, leitura da palma da mão ou folhas de chá, até a consulta a oráculos, videntes, profetas, pajés, ciganos, bolas de cristal e mapas astrológicos foram usados para atender à tais preocupações (Polak, 1971,pp. 24-26) Referências ao futuro também são encontradas em diversos ritos de passagem em diferentes sociedades, nas quais as cerimônias reconhecem as transições para futuros papéis sociais, ou em rituais religiosos que buscavam controlar a caça ou a colheita. Ainda, o desenvolvimento de calendários e relógios serve como indicação não só do interesse do homem no movimento celeste que acabou se tornando uma medida universal de tempo 
(Bell, 2005). Em diversos momentos da história da civilização ocidental a religião, a filosofia, a ciência e os estudos de utopias também forneceram encorajadores perspectivas da condição humana (Polak, pp. 38-141, 185-221). Curiosamente, o conceito original de utopia, literalmente "qualquer lugar", parece, ao final do século XVIII, ter sido substituído radicalmente por outro, o de outro tempo, o futuro (Bell, 2005).

A recente experiência humana de aceleração rápida nas mudanças cientificas, tecnológicas, sociais e culturais que parecem ocorrer nos últimos séculos levaram diversos futuristas a escrever os estudos do futuro como um fenômeno "distintamente moderno". Segundo Edward Cornish:

(...) o futurismo foi desenvolvido por cientistas e estudiosos que desejavam aplicar o conhecimento à solução de problemas. O estudo do futuro leva em consideração o fato histórico e o conhecimento cientifico e adiciona a estes valores humanos e imaginação para criar imagens do que pode acontecer no futuro. O estudo do futuro é a ciência na ponta dos pés; é a história tentando olhar para frente ao invés de para trás. (Cornish et al., 1977, p. 51).

Durante uma palestra patrocinada pela Royal Institution in 1902, Herbert George Wells (um dos primeiros e mais influentes escritores futuristas), mais uma vez buscava por um fim às dúvidas daqueles que acreditavam ser impossível saber qualquer coisa a respeito do futuro e conclamava pela criação de uma "ciência do futuro":

É para o futuro que vamos, no amanhã está o acontecimento que nos interessa. Lá está o que resta a ser vivido por nós e por nossos filhos e tudo que nos é caro. Muitas pessoas acreditam que não pode existir nenhum tipo de certeza em relação ao futuro. Pode-se conhecer tanto sobre o futuro, como um amigo recentemente me garantiu, quanto se pode saber da direção para qual um gatinho irá saltar (..) É na nossa ignorância do futuro e na nossa convicção que tal ignorância é absolutamente incurável que sozinhas dão ao passado sua enorme predominância na nossa maneira de pensar. No entanto através dos tempos, uma longa e ininterrupta sucessão de videntes - que ainda estão a prosperar - serve de testemunho para a sensação perene que ainda arde de que, afinal, pode existir um tipo melhor de conhecimento - um tipo de conhecimento mais útil do que aquele que possuímos atualmente (..) Realmente é, afinal, algo tão extravagante e sem esperança sugerir que, 
ao buscar causas operacionais ao invés de fósseis e ao criticá-las intensa e persistentemente como os dados geológicos foram criticados, talvez seja possível lançar algum tipo de luz vinda da inferência ao que virá ao invés do que veio e obter um senso comum claro daquilo que está por vir, que seja tão universalmente convincente e infinitamente mais importante para a humanidade do que uma visão clara do passado que a geologia nos ofereceu no século XIX?(...) Eu acredito com convicção que um conhecimento indutivo de um grande número de coisas no futuro está se tornando uma possibilidade para o homem. Acredito que está chegando o momento onde será possível sugerir a exploração sistemática do futuro. (Wells, 1902, pp. 327-329)

Entretanto o aparente entusiasmo em relação a essas novas idéias parece ter diminuído intensamente com o advento da Primeira Guerra Mundial e a conseqüente desilusão de milhares de pessoas com a sociedade, caracterizada pelos anos de depressão econômica que se seguiram e se, anteriormente, a fé em Deus havia sido substituída pela fé na ciência e tecnologia como representantes do progresso, naquele momento a impressão era de que essa mesma ciência e tecnologia pareciam ameaçar seus criadores (Lukacs, 1970).

A cautela tornou-se aparente até nas obras posteriores de Wells. Em The Outline of History (1920), a "história humana torna-se cada vez mais uma corrida entre a educação e a catástrofe" e em seu último livro Mind at the End of Its Tether (1945), ele declarava que "o fim de tudo aquilo que chamamos de vida está perto e não pode ser evitado... Não existe alternativa, solução ou fuga de tal impasse.É o fim". O desenvolvimento de um gênero literário, o da distopia, parece ser resultado desse colapso na crença em relação ao progresso ${ }^{2}$. Paralelamente, todavia, essas visões de futuro negativo se justapuseram à outras visões positivistas, encontradas em previsões publicadas em veículos como Popular Science Monthly que em 1922, por exemplo, organizou um simpósio com um grupo de inventores que incluía Thomas Edison e Nicholas Tesla.

2 Uma amostra das obras desse gênero de relevância particular incluiria "We" de Eugene Zamiatin (1917); "Admirável Mundo Novo" de Aldous Huxley (1932); "1984", de George Orwell (1949); "Player Piano", de Kurt Vonnegut (1952); "Fahrenheit 451", de Ray Bradbury (1953) e "Laranja Mecânica", de Anthony Burgess (1962) 
Quando Herbert Hoover foi eleito presidente dos EUA em 1928, ele trouxe consigo a experiência em planejamento obtida em seu trabalho na elaboração dos relatórios Business Cycles and Unemployment (1923) e Regulation of Employment (1925). Tais trabalhos apontavam para a necessidade dos EUA desenvolverem e implementarem planos de 5 a 10 anos para garantir 0 desenvolvimento econômico.

Seu próximo passo foi a criação de um comitê de pesquisa sobre tendências sociais, liderado pelo sociólogo William F. Ogburn, o"Pai da Avaliação Tecnológica", denominação que ele recebeu depois que os trabalhos de seu comitê articularam os conceitos de impacto social e os custos da inovação em tecnologia, além de sugestões de um planejamento econômico e social abrangente para as taxas de crescimento populacional e de consumo desiguais (Cornish, p.74). Outra de suas participações relevantes deu-se na elaboração de um relatório de tendências tecnológicas e de implicações sociais de novas invenções em 1937 que, segundo Norris (1983, p.65), acabou se tornando "a primeira grande tentativa de mostrar quais tipos de novas invenções podem afetar as condições de vida e de trabalho nas América nos próximos 10 a 25 anos".

\subsection{DESENVOLVIMENTO DOS ESTUDOS DO FUTURO A PARTIR DE 1945}

Segundo Jones (1979, p.14), somente depois do término da Segunda Guerra Mundial é que o campo moderno dos estudos do futuro moderno surgiu. Uma renovação no interesse e maior sofisticação na abordagem dos estudos do futuro surgida na década de 60 baseou-se em parte no trabalho de futuristas como Harrison Brown e Herman Kahn (Norris, p. 71). 
O trabalho destes e de outros futuristas surgidos nos primeiros anos do pós-guerra indicam com clareza o impacto da bomba atômica e da crescente ameaça de guerra nuclear em suas idéias relacionadas ao futuro. Curiosamente, H.G. Wells previu a descoberta da radioatividade artificial e da criação da bomba atômica, além de uma guerra envolvendo a Inglaterra, a França, a América e a Alemanha em sua obra de 1913 The World Set Free. A exposição da equação que causaria a explosão da bomba foi feita pelo físico refugiado Leo Szilard em 1932 (dois anos após ler o livro de Wells), seguida pela criação do Projeto Manhattan e de sua conclusão bem sucedida em Alamagordo. Diversos cientistas envolvidos no projeto, no entanto, expressaram sua preocupação em relação à responsabilidade moral que acompanhava tal projeto num relatório, o Relatório Franck, onde foram empregadas diversas técnicas como a gerência de uma précrise, e planejamento normativo (hoje usadas em previsão e avaliação tecnológica) para prever as possíveis conseqüências de um bombardeio às cidades japonesas. A conclusão era de que o horror que tomaria conta do mundo destruiria as chances de criação de controle internacional efetivo no uso de energia atômica, que segundo Jungk (in Norris, p.81), resultariam, por fim, numa corrida acelerada por armas atômicas.

Não surpreendentemente, as imagens negativas continuavam a ser o foco predominante nas visões futuristas do período, geralmente construídas pela combinação do uso cada vez maior da tecnologia por parte de uma elite, na opressão de seres humanos, do funcionamento de organizações que tornassem os instintos humanos elementos controláveis pela inteligência, ou mesmo de condicionamento psicológico para "adequar" os membros de uma sociedade a seu espaço.3

Em contrapartida, outros pensadores ocidentais forneceram caminhos para o desenvolvimento de um pensamento futurista nesse período que se seguiu a Segunda Guerra Mundial, ao tentar responder a seguinte pergunta: podemos

3 Três obras desse período pós guerra destacam-se nesse sentido: Walden 2, de B. F. Skinner (1948); Post-historic man: an Inquiry de Roderick Seidenberg (1950) e The Technological Society, de Jacques Ellul (1954). 
conhecer o futuro? O existencialismo tornou-se, então, uma das maiores fontes de pensamento futurista. Para Jean Paul Sartre, cada ser humano cria seu próprio futuro e deve assumir sua responsabilidade nessa criação. Essa visão é uma diferença fundamental de percepções ocidentais anteriores sobre o futuro, uma vez que ela indica que o futuro é "algo a ser criado ou inventado e não apenas algo que se sucederá independente da vontade humana”.(Norris, p.83)

Em 1957, Gaston Berger cria na França o Centre International de Prospective em Paris e passa a publicar Prospective, publicação que aborda diferentes aspectos do futuro. Berger usa o termo prospecção como uma atitude mental que deve ser adotada ao se pensar nos problemas do futuro:

A prospecção não é nem uma doutrina nem um sistema. É uma reflexão do futuro que busca descrever sua estrutura geral com o objetivo de realçar elementos de um método que seja aplicável ao nosso mundo em aceleração.

Assim essa descrição revela que o futuro é bastante diferente da nossa percepção comum deste. Não é uma 'região' em particular da continuidade temporal. Não é simplesmente uma série de momentos que ainda estão por ocorrer. O tempo, em sua totalidade, não é um tipo de substância contínua ou fluida que se move em seqüência regular em torno da qual acontecimentos se associam. Para o homem, o passado e o futuro são heterogêneos. Não são momentos da mesma série. Não possuem significado concreto, nem significado humano, exceto quando os relacionamos à nossas ações: o passado é o que foi feito... Para nos voltarmos ao futuro, ao invés de olharmos para o passado, não basta simplesmente mudarmos de cenário, devemos mudar de "ver" para "fazer" (...) Usar ações de prospecção é nos prepararmos para agir.

( in Courman, A. e Levy, M. eds. 1973: 43)

Essa preocupação com a concretização das imagens do futuro também encontra eco no trabalho do sociólogo e filósofo holandês Fred Polak. Em sua obra The Image of the Future (1961), ele examina o relacionamento entre a prevalência das imagens positivas e negativas de futuro e a ascensão e queda de sociedades ocidentais e sugere que o colapso da sociedade ocidental estaria próximo, graças à falta de imagens positivas no período e de uma inédita, em termos históricos, atitude negativa em relação à construção destas visões mais positivas, que trouxessem um equilíbrio a essa perspectiva. Para contrabalançar 
tais efeitos, ele propunha a adoção de prognósticos ("prognostics") - termo de sua criação - como o termo representativo dos estudos do futuro. Ele o descreveu como "uma nova ciência possível a ser construída, que no momento encontra-se em estágios iniciais. Quando ela atingir a maturidade, nós poderemos chamá-la de ciência do futuro" (1973: p.14).

Bertrand de Jouvenel, outro futurista francês importante, rejeitou tanto os termos 'futurologia' como 'prognóstico", porque estes indicavam uma base científica nas previsões dos futuristas e, segundo ele, não existiria conhecimento do futuro já que conhecimento implica em certeza e o futuro, em princípio, é incerto. O que poderíamos fazer, segundo ele, era 'conjeturar". Os estudos do futuro não seriam, enfim uma ciência, mas sim uma 'arte', onde a visão é um ato de imaginação de um possível futuro derivado a partir de um estado presente, que conhecemos em vários níveis.

Tal posição era uma reação à defesa da 'futurologia' feita pelo cientista político alemão Ossip K. Flechtheim, que defendia que "nesse momento de crise não permite que tratemos a 'futurologia' como 'arte pela arte'. Nossa sobrevivência depende da solução de problemas básicos (...) somente poderiam ser resolvidos pela nova ciência da futurologia" (1966, p. 72). O que nos parece ser particularmente relevante aqui é a mudança do conceito de 'ciência'. Flechtheim busca entendê-la em sua definição mais ampla de "sistema de conhecimento organizado relacionado aos fatos de um assunto em particular", ao invés de seu sentido mais restrito de "ciência exata". Assim, tal ciência seria uma combinação de analise estatística em termos mais quantitativos, com um reconhecimento de fatores sócio-culturais únicos que estão na base das atividades de planejamento, resultando assim em uma afirmação crível de caráter qualitativo, uma vez que baseada tanto em raciocínio indutivo como dedutivo

Também, essa perspectiva era necessária para ultrapassar as quatro predominantes formas de reificação: a ideologia, a utopia, a anti-utopia e o "fim da ideologia". E ainda que o estudo do futuro devesse oferecer uma analise crítica radical do status quo, ele "não concebe o futuro nem como um paraíso 
utópico ou como o inferno anti-utópico". Flechtheim foi além da discussão ciência - ou - arte para defender a necessidade de um novo ramo de conhecimento, ainda que este fizesse uso de especulação e intuição.

Outras razões também contribuíram para um interesse renovado no futuro nos EUA após o fim da Segunda Guerra Mundial: as bases industriais americanas foram pouco afetadas pela guerra; a vitória na guerra fortificou uma atitude otimista na população americana; e a crescente ameaça nuclear soviética encorajou as atividades de previsão estruturadas em diversos níveis do governo e da indústria (Jones, p.16).

De fato, necessidades estratégicas levaram à criação de uma agência governamental em 1946, a RAND, inicialmente como um braço do projeto de previsão da força aérea americana, e voltada às questões de defesa nacional e guerra nuclear, especialmente no que se referia a sistemas armamentícios. A análise de sistemas teve um papel fundamental no desenvolvimento de uma metodologia do estudo do futuro e foi de influência especial no trabalho de Herman Kahn (Norris, p.91).

Depois de seu período trabalhando com a RAND, Kahn escreve On Thermonuclear War em 1961, já trabalhando para o Instituto Hudson. Nesse trabalho ele incorpora a análise de sistemas e técnicas de construção de cenários no desenvolvimento dos argumentos relacionados à estratégia nuclear americana, que acabariam por fazer com que o governo revisasse essa política. Enquanto Kahn foi um dos pioneiros no uso de construção de cenários, seus colegas do RAND Olaf Helmer e Norman Dalkey iniciaram o uso de técnicas Delphi no mesmo período. O uso dessas técnicas somado à introdução de simulações em computador e modelos de teoria de jogos acabou fazendo com que o trabalho desenvolvido na RAND fosse além da base político-militar desta e gerassem estudos abrangentes e de longo prazo (Jones, p.21).

Outros futuristas do período, como Harrison Brown abordaram a tarefa de forma mais ampla e incluíram considerações de natureza ecológica, social, 
internacional e aspectos imaginativos, assim como o foco tecnológico e científico mais tradicional. Assim, não apenas um, mas três alternativas prováveis de futuro eram sugeridas: um futuro mais provável, retratado em um retorno à sociedade agrária, caso a humanidade não conseguisse resolver os problemas relacionados à guerra, população e energia; um futuro um pouco menos provável, retratado por uma sociedade industrial completamente controlada e coletivizada e uma terceira alternativa, mais desejável, mas menos provável ainda, de uma sociedade industrial onde o homem vive em harmonia com seu meio ambiente.

Thomas Jones resume a importância formativa desse período entre 1945 e 1960 nestas palavras:

De um modo surpreendente e em grande escala, a história das origens do futurismo americano pode ser contada em termos das respostas da RAND e da Caltech durante os anos 50 para as mudanças de percepção em relação a um mundo nuclear e tecnológico. Destas instituições surgiram duas linhas distintas de pensamento voltado aos estudos do futuro. (...) A heterogeneidade do futurismo, ainda mais clara nas abordagens divergentes de seus fundadores europeus tornou-se inconfundível nas abordagens contrastantes do futurismo americano durante a década de 50.

Ao final da década de 50 , as bases para o futurismo haviam sido lançadas, O milieu sócio-cultural tornava-se cada vez mais receptivo ao pensamento voltado ao futuro. Embora seja possível argumentar que o futurismo começou essa decolagem gradual durante o meio e o final da década de 50, o salto repentino deu-se em 1962 e 1963. Deste então, o futurismo ganha cada vez mais ímpeto. (1979: 19)

Em 1967, Bertrand de Jouvenel cria o projeto Futuribles em Paris e dissemina as idéias do pensamento futurista através de diversos projetos de previsão e planejamento (que aplicavam as idéias de Gaston Berger relacionadas à 'prospecção'), que acabaram por solidificar a filosofia do futurismo europeu como movimento intelectual, principalmente através da publicação de $A$ Arte da Conjectura. No ano seguinte, o Clube de Roma é fundado pelo economista e empresário Aurolio Peccei, patrocinando quatro projetos voltados à solução da 'problemática mundial', resultando na publicação de diversos relatórios, entre eles Os Limites do Crescimento (1972, posteriormente atualizado em 2004); Objetivos 
para Humanidade, um Relatório do Clube de Roma Sobre os Novos Horizontes da Comunidade Global (1977); A Revolução Descalça (1988), Levando em Conta a Natureza: O Caminho de uma Renda Nacional Sustentável (1995); $A$ Sociedade da Informação e a Revolução Demográfica (2001) e A Hélice Dupla do Trabalho e do Aprendizado (2003).

Outra instituição importante é fundada em Washington em 1966 - a World Future Society, voltada à contribuição do conhecimento e consciência do futuro e de seu estudo; ao avanço das investigações sérias a respeito do futuro, à promoção do desenvolvimento de métodos para o estudo do futuro; ao aumento da compreensão dos estudos do futuro por parte do grande público e à disseminação e cooperação entre organizações e indivíduos que estudam ou planejam para o futuro. Assim, essa organização publica uma variedade de livros, revistas científicas e boletins. além de promover conferências e atividades nacionais e internacionais, contando atualmente com milhares de membros.

À medida que as preocupações dos futuristas dos anos 50 e 60 tornavamse mais tangíveis nas duas últimas décadas do século $X X$, outras instituições voltadas aos estudos do futuro começam a surgir em outras partes do planeta, como por exemplo, a World Future Studies Federation, criada em Paris, em 1973, que agrupa outras 20 instituições semelhantes ao redor do planeta. É em meados da década de 80 que organizações semelhantes começam a se formar no Brasil, a saber: o Programa de Estudos do Futuro da FIA - Fundação Instituto de Administração (Instituição conveniada com a FEA/USP), em 1989; a Escola do Futuro da Universidade de São Paulo em 1989; o Núcleo de Estudos do Futuro da PUC-SP e o Laboratório de Estudos do Futuro da Universidade de Brasília, em 1998. Segundo Litto:

É pouco quando consideramos a importância do país no cenário global e suas próprias necessidades internas. Afinal, se nós não tentarmos modelar o nosso próprio destino, outros o farão. (in Siqueira, 2004 pp.212218). 


\subsection{TERMOS UTILIZADOS E SEU SIGNIFICADO}

Um apanhado dos termos comumente usados nesse campo de estudo nos parece relevante pelo fato de que vários grupos e organizações voltados a esse tipo de trabalho do 'futuro' vêm usando diferentes termos em suas representações especiais do futuro e, dessa maneira, nem sempre facilitam uma compreensão mais precisa de seus objetos de estudo ou da natureza do trabalho envolvido. Conseqüentemente, trabalhos anteriores de investigação também procuraram (re) definir e organizar tais termos de formas diferentes. Segundo Kauffman:

O nome da profissão à qual estes futuristas pertencem não é ponto unânime de acordo. Entretanto, 'futurismo' parece muito com uma ideologia, enquanto que 'futurologia' - além de ser uma desajeitada mistura de latim e grego - parece semelhante demais à astrologia ou cientologia (associações as quais a maioria dos futuristas gostaria de evitar). Então "futurística" - literalmente, aquilo que um futurista faz tornou-se o termo automaticamente dominante, ainda que não universal. (1976, p.232)

Entretanto, em outro trabalho publicado no mesmo ano Kauffman refere-se a esse tipo de estudo como 'futurismo', o que evidencia aqui a dificuldade dos próprios praticantes na escolha de um termo comum.

Norris (pp: 9-11) sugere uma organização de termos que nos parece particularmente relevante, a de que tais palavras podem ser classificadas em três grandes grupos:

a- termos freqüentemente usadas por várias pessoas interessadas em vários aspectos do futuro como futurista, futurismo, futurística e estudos do futuro;

b- termos defendidos por alguns pensadores e de aceitação por alguns grupos de interesse ou regiões geográficas como futurologia, prognóstica e arte da conjectura; 
c- termos pouco usados ou de pouca aceitação como probabilística, futurografia e melontologia.

Para efeito de uniformidade e facilidade de compreensão, este trabalho vai utilizar termos do primeiro grupo acima, devido à sua maior popularidade e abrangência.

Futurista é aquele que tenta tornar o futuro mais real para os outros. Para conseguir isso, ele busca esclarecer as possibilidades futuras, comunicá-las aos outros e trabalhar para torná-las realidade. Alguém que "tenta prever o imprevisto ou inesperado e estudar possibilidades para a melhoria da condição humana". (Shane, 1973, p.12)

Futurismo é, essencialmente, uma orientação especulativa daqueles que se consideram futuristas, baseada em três princípios básicos: a unidade da realidade; a importância fundamental do tempo e a importância crucial das idéias, especialmente aquelas referentes ao futuro (Cornish, pp. 256-258).

Estudos do futuro é o termo usado para descrever o campo de estudo no qual o futurista opera. Assim, o campo procuraria "identificar, analisar e avaliar as possíveis mudanças no futuro e no mundo através de um conjunto de atividades especificas que dependem do futuro como principio organizador" (Cornish, pp. 256-258). Uma definição mais ampla descreve o campo como uma disciplina que busca especificamente um estudo sistemático de alternativas possíveis para 0 futuro ${ }^{4}$. Pelo fato de ser bastante ampla, ela retém a abrangência necessária para incorporar as diferentes visões do trabalho envolvido nessa área, sem necessariamente se ater à determinada evolução ou direcionamento deste tipo de trabalho. Ainda, a utilização do termo estudos do futuro dentro desta acepção nos parece particularmente relevante, uma vez que esta também sugere a

$4 \quad$ Uma consulta mais ampla nesse sentido incluiria os trabalhos de Kauffman, Jr. Draper L. (Futurism and Future Studies, 1976), e Guy, Cynthia B. (A Survey of Pre-High School Future Studies Programs, Ed. D 1978) e Future Studies in US High Schools in World Future Society Bulletin, (May-June 1987) 
possibilidade da combinação com o ensino do futuro, dentro desta perspectiva de disciplina com estudo sistemático, o que é, por fim, o objeto de estudo deste trabalho.

\subsection{ESTUDOS DO FUTURO E SEU OBJETO DE ESTUDO}

Considerando-se que existem fatos passados, opções presentes e possibilidades para o futuro e não possibilidades passadas e fatos futuros, os estudos do futuro precisam lidar com o paradoxo de que não existe conhecimento real sobre o futuro e que somente um outro tipo de conhecimento poderá permitir que façamos afirmações sobre o futuro.

Como resultado natural de um campo de estudo ainda em desenvolvimento, a diversidade de abordagens em si é um reflexo de como os estudos do futuro foram encarados à medida que experimentos e projetos eram realizados. A busca de uma maior sistematização desses estudos (o que, por si, permitiria o alçar desses estudos à condição de "ciência" ou "arte") acabou por gerar um número variado de modelos conceituais, dentro dos quais tais estudos pudessem ser realizados. Ainda que, até o presente momento, um modelo conceitual comum não tenha sido alcançado pelos futuristas praticantes, essas diversas abordagens, entretanto, nos informam claramente da diversidade de aplicações destes estudos do futuro.

A busca por uma tipologia funcional que servisse como modelo estrutural para o estudo do futuro tem sido motivo de discussão e análise por parte de vários futuristas. Três forças parecem agir concomitantemente no intuito de dificultar um consenso maior nesse sentido: o objeto de estudo em questão desse campo, a diversidade encontrada nas ferramentas utilizadas para estudar o futuro e, por fim, as próprias expectativas em relação ao futuro dos profissionais 
da área, que acabam por servir como parâmetro para tais estudos.

Como já discutido anteriormente, o significado do termo "futuro" pode abranger um espectro que vai desde a compreensão das conseqüências causais diretas do presente, até a visão de um sistema ou conjunto de fatos que ainda estão por vir, e que podem (ou não) estar ligados a estas causas. Enquanto o primeiro destes significados sugere uma visão de futuro mais "normativa" (ou seja, o futuro é de certa forma, o resultado "inevitável" do presente), o segundo parece sugerir uma visão de alternativas (ou seja, as causas apontam para diversas opções a serem tomadas).

Para abrirmos nosso caminho no mundo, o único conhecimento realmente útil é o conhecimento do futuro. Essa suposição nasce do fato que o passado não mais existe: está encerrado. Embora nós possamos aprender mais sobre o passado à medida que desencavamos mais fatos e embora possamos reinterpretá-lo e mudarmos nossos conceitos a seu respeito, não podemos mudar o passado em si. Mas o futuro é diferente, porque ele ainda não aconteceu. O futuro pode ainda se curvar à vontade humana. Podemos até mesmo nos adaptar com sucesso a acontecimento iminentes que estão além do controle humano, se estes forem antecipados. (Bell, 1996, p.9)

Conseqüentemente, estes estudos tratariam, a grosso modo, de um esforço contínuo de análise de imagens do futuro e este seria um ponto de partida epistemológico para os estudos do futuro. Assim, da mesma forma que estudos históricos procuram explicar os fatos passados e as causas destes, os estudos do futuro buscam discutir o potencial do presente para a construção de uma ou várias imagens do futuro. Para tanto, seriam necessárias a coleta de dados quantitativos e qualitativos, seguidas de observação e análise destes à luz de modelos teóricos provenientes de disciplinas como a economia, a sociologia, a geografia, a história, a engenharia, a matemática, a psicologia, a biologia e a teologia, por exemplo. Bell (1996, p.13) sugere que apesar de diversas suposições em comum com estas áreas do conhecimento, os estudos do futuro adotam uma perspectiva que, no conjunto, é distinta: 
1. O tempo move-se de maneira unidirecional e irreversível a partir do passado em relação ao futuro. Alguns princípios servem de base para esta suposição como a segunda lei da termodinâmica (a entropia sempre segue em uma direção), o desenvolvimento biológico (os seres envelhecem com o passar do tempo); movimentação de ondas (a recepção nunca ocorre antes da emissão): a história do universo (a radiação residual indica que o tempo tem início, seqüência, duração e direção); e marcas do passado ('pegadas' na areia são uma evidência presente do passado).

2. Nem tudo que irá existir existia antes ou existe agora. Assim, o futuro pode conter coisas que nunca existiram antes. Estas sugerem novas idéias, novas reações e uma nova compreensão.

3. Pensar sobre o futuro é essencial para a ação do homem. A reação é possível sem esse pensamento, mas não a ação, porque a ação requer antecipação. Portanto, imagens do futuro (objetivos, intenções, esperanças, medos e aspirações) são partes das causas das ações do presente.

4. O futuro não está totalmente pré-determinado. Tal suposição reconhece explicitamente que o futuro não existe ou está "em aberto".

5. Até certo ponto, os resultados futuros podem ser influenciados por ações individuais e coletivas e pelas escolhas feitas pelas pessoas.

6. A interdependência global sugere uma perspectiva holística e uma abordagem multidisciplinar. Os estudiosos do futuro enxergam o mundo de forma tão inter-relacionada que nenhum sistema ou unidade pode ser analisada como totalmente isolada. Cada unidade, afirmam, deve ser considerada um sistema em aberto . 
Dessa forma, apesar da freqüente e intermitente combinação destas diferentes disciplinas em sua realização, os estudos do futuro parecem diferir destas pelo fato de examinarem o futuro (e não apenas o possível, mas aquele provável,desejável ou improvável) através da obtenção de uma visão sistêmica ou holística baseada em princípios oriundos destas disciplinas. A finalidade é a de "manter ou melhorar o bem estar da humanidade e as capacidades do planeta Terra em sustentar a vida" (Bell, p. 14) através da utilização de pensamento prospectivo e da criação de novas imagens alternativas de futuro, explorações visionárias daquilo que é possível, investigação sistemática do que é provável e da avaliação moral do que é preferível.

Mesmo se considerarmos que "uma afirmação sobre o futuro não pode ser feita com a pretensão de que ela seja verdadeira; podemos sempre imaginar que o contrário irá acontecer e não temos garantia alguma que a experiência futura não irá nos apresentar como real aquilo que hoje é imaginação" (Reichenbach, 1951 p.241), podemos também considerar que o conhecimento conjetural é possível, uma vez que justificar crenças em relação ao passado e ao presente não é fundamentalmente diferente de justificar crenças em relação ao futuro. Tudo dependeria do processo de refutar proposições e de aceitar aquelas que não forem refutadas e por conseguinte, justificar racional e objetivamente nossa crença em determinada proposição, mesmo se não pudermos justificar a veracidade da proposição em si (Musgrave, 1993).

Portanto, os estudos do futuro têm objeto de estudo e objetivo específicos, utilizando-se de métodos e epistemologias já estabelecidos na busca de conhecimento conjetural (ou seja, o conhecimento baseado em uma proposição). O que poderia, a priori, parecer então um obstáculo à percepção dos estudos do futuro como uma disciplina em si, é, para Slaughter, razão para validação desta:

(...) os métodos de pesquisa e aplicações dos estudos do futuro são claros: investigação acadêmica, formulação de hipóteses, crítica e inovação social, argumentação e tentativa de renegociação de práticas culturais e significados estabelecidos. As formas de avaliação habituais aplicam-se a este tipo de trabalho: as relações entre as evidências, a qualidade da discussão, a utilidade, etc. Estas o localizam dentro das 
correntes da vida intelectual. O que é distinto no trabalho com os estudos do futuro é que estes buscam uma visão maior daquela que é geralmente obtida pelos outros campos e disciplinas mais restritos em seus focos, que estes possuem uma gama de métodos para investigar futuros em potencial (e seus impactos no presente) e que portanto eles ampliam e estendem nossa capacidade de efetuar julgamentos cuidadosos de longo prazo. Tais qualidades são de grande utilidade social. (Slaughter, art. 213.htm, 2005).

\subsection{ESTUDOS DO FUTURO: QUAL FUTURO?}

A seguir, procuraremos mostrar como os estudos do futuro, ao longo de sua evolução, incorporaram não somente as técnicas, mas também os modelos conceituais e epistemológicos de diferentes disciplinas. A falta de um consenso maior em determinado modelo conceitual poderá ser explicada pela evolução de sua trajetória como disciplina, à medida que os princípios de diferentes disciplinas passaram a ser incorporados e aplicados na realização destes estudos, estes acabaram por evidenciar as diferentes visões que permeavam a abordagem dos trabalhos.

A princípio, o tipo de trabalho realizado no período pós-guerra facilitou a disseminação de estudos do futuro científico-tecnológicos, tendência que permaneceu praticamente inalterada nas décadas de 60 e 70 (Jones). Tais estudos usam, na maior parte das vezes, abordagens criadas a partir de uma orientação de controle e administração. Os futuristas buscariam diminuir o estresse e o deslocamento gerados por uma situação presente pelo controle de eventos futuros e através do uso de sofisticadas técnicas de previsão, parte integral de uma teoria de sistemas cibernética abrangente. Ao mesmo tempo em que reconhecem que o uso dessas ferramentas tecnológicas teve efeitos perniciosos significativos, os futuristas da escola científico-tecnológica mantêmse fieis à visão de mundo prevalecente na cultura ocidental. Basicamente, a solução dos problemas virá através da criação de tecnologias mais poderosas. 
Com esse propósito de controle através da solução de problemas por parte de especialistas, tais abordagens parecem estar mais voltadas ao alívio de problemas atuais do que a criação de futuros alternativos genuínos. O inerente viés metodológico no uso de ferramentas e parâmetros quantitativos, oriundos de ciências usadas na criação de políticas sociais, freqüentemente negligencia conseqüências de caráter não-quantitativo, ou seja, os custos sociais das soluções propostas e questões fundamentais como guerra e violência. (Halley e Vatter, 1988, pp:53-82).

Partilhando dessa visão crítica dos estudos do futuro científicotecnológicos encontram-se os futuristas participativos. Estes temem o surgimento de uma elite meritocrática, responsável pelo controle ditatorial ou totalitário do comportamento, e enfatizam a participação em larga escala na seleção, ordem e implementação de planos de longo prazo para a humanidade. Ainda, notando que dentro do próprio campo de estudo existiam marcadas diferenças em relação ao resto da sociedade, Alvin Toffler (1972) chegou a comentar que os estudos do futuro eram dominados por homens brancos, de classe média-alta e de orientação marcadamente liberal. Segundo Slaughter:

A previsão tecnológica tornou-se uma ferramenta generalizada de uso tão amplo que ela pareceu entregar o domínio do futuro para outros contextos, especialmente o das finanças e da economia. Qual seriam os níveis de demanda para uma ponte, aeroporto ou usina?.Que tipo de retorno de investimentos poderia ser esperado? Tal iniciativa seria um bom investimento financeiro? (...) Em resumo, a previsão tecnológica floresceu nas últimas décadas porque ela tentou resolver tais problemas e oferecer a investidores, corporações, governos e outros indivíduos as ferramentas para a tomada de decisões. Contudo, ao mesmo tempo, ela perdeu parte de seu interesse. Isso aconteceu por algumas razões que incluem (a) a percepção desta era a de um exercício técnico, em grande parte; (b) era organizada por aqueles que detinham o poder (c) ela fracassou na tentativa de mudar o status quo. (2003, pp: 100-107)

Para contornar esse impasse, outros futuristas como Robert Ingersoll, John Byrne, Daniel Rich (1981) e Elise Boulding (1979) sugerem que o campo dos estudos do futuro pode ser dividido entre os futuristas que abordam o estudo 
do futuro de um modo mais científico e estrito e aqueles que o vêem dentro de uma perspectiva mais aberta, especulativa e visionária. Ingersoll e Rich afirmam que "a função destes estudos é a de dirigir e planejar os esforços dos homens e das sociedades através de um labirinto de futuros possíveis e prováveis" (p.32), em crítica direta aos estudos do futuro científico-tecnológicos que se baseavam numa visão científica restrita, na qual a extrapolação de tendências fornecia a base para o planejamento e as decisões a serem tomadas.

Dentro de uma visão exclusivamente científica-tecnológica, tais futuristas presumiriam a ordem e a continuidade históricas, em detrimento dos saltos imaginativos existentes no pensamento utópico. Assim, o futuro poderia ser compreendido através de referências ao passado e ao presente, de forma empírica e preditiva, tornando-se uma mera extrapolação dos fatos coletados e organizados dentro dos requisitos de um paradigma de conhecimento existente.

Naturalmente, trabalhos mais recentes como o de Bell (1996), explicitam a relação recíproca entre previsão e o poder nesse tipo de abordagem, uma vez que podemos nos preparar de maneira mais adequada se soubermos, por exemplo, que uma catástrofe natural está prestes a acontecer. Slaughter (2003), no entanto, argumenta que 'prever o futuro' em larga escala parece estar em conflito com a 'impossibilidade do conhecimento' ou o aspecto 'não-mensurável' de vários aspectos culturais e sociais, como também com uma visão das pessoas como agentes da história. Uma previsão exata do futuro nos tornaria meros observadores passivos dos acontecimentos e, portanto, sugere que previsões deste tipo geralmente funcionam em problemas de menor escala. Os estudos do futuro deveriam então, segundo ele, ser uma combinação entre os aspectos 'conhecidos' e' 'desconhecidos' do futuro.

Numa tentativa de lidar com esses aspectos 'desconhecidos' do futuro, o Instituto Hudson desenvolveu o uso formal de cenários, termo surgido no fim do século XIX na Itália. Inicialmente as preocupações militares e estratégicas fomentaram seu uso, mas este se disseminou rapidamente nas décadas de 80 e 90, já que a natureza do trabalho envolvido na construção de cenários permitia 
uma mudança de foco no trabalho de antecipação para uma nova direção. Até certo ponto, esta poria de lado qualquer esperança de uma previsão correta em favor de dois outros ganhos: a exploração das divergências e a preparação para as mudanças. Ao contrário também da previsão tecnológica e do rigoroso uso de ciências exatas, necessários para sua utilização, a criação de cenários começava a partir de uma simples exploração conceitual e da execução de processos envolvendo grupos de trabalho.(Slaughter, 2003)

Talvez um dos exemplos mais famosos de utilização de cenários seja o projeto Mont Fleur, desenvolvido na África do Sul e que ajudou o país a se preparar para a transição 'milagrosa' de um governo minoritário para um governo majoritário em 1994. (Kahane, 2002, p.33)

Esta e outras iniciativas semelhantes apontam para uma questão básica nos estudos do futuro: os aspectos relacionados à transição da situação sóciocultural. Estes são ocorrências raras de importância crítica e uma navegação bem sucedida destes períodos depende de uma re-estruturação fundamental de valores individuais e da sociedade dentro de um período de tempo relativamente curto. (Norris, p. 82)

Por outro lado, iniciativas desta natureza também colocam os estudos do futuro como 'parte' de um processo de planejamento e análise de políticas, e o crescimento dos estudos do futuro é também resultado do desejo de governos e outras formas de administração em descobrir informações que os ajudem a criar melhores políticas. Ao mesmo tempo em que os estudos do futuro podem fazer parte da segunda ou terceira escala de análises de políticas de longo prazo, Polak (1973, p.36) e Bell (1996) sugerem que estes não são apenas uma extensão desse trabalho, mas sim um campo em separado:

1- Ao contrário da análise de políticas, geralmente com uma orientação a curto prazo ( geralmente de 1 a 5 anos), as teorias e ações dos estudos do futuro têm orientação de longo prazo (de 5 a 50 anos); 
2- $\quad$ Oxame de uma gama de futuros possíveis é o foco dos estudos do futuro. Estes partilham com a análise de políticas os objetivos de criação de novas estruturas e o conhecimento melhor das estruturas atuais, mas não tanto a preocupação destes últimos em prever o futuro para melhor controle.

3- Os estudos do futuro preocupam-se mais com o questionamento de suposições básicas, buscando ir além do presente para criar a possibilidade novos futuros, em cenários os mais distintos entre si. Análise de políticas, por outro lado, partilham com 0 planejamento administrativo uma orientação técnica, voltada à viabilidade de determinadas políticas e não do questionamento destas.

4- $\quad$ objetivo dos estudos do futuro têm uma orientação mais voltada à visão do que aos objetivos (essenciais à análise de políticas e ao planejamento). Buscam alinhar visões individuais às institucionais mostrando o que é possível dentro de um processo o mais participativo possível.

5- Enquanto o planejamento e análise de políticas podem ser operacionalizados (ou instrumentalizados), o mesmo não ocorre com o poder de uma visão de futuro, sem a qual organizações, nações ou civilizações entrarão em declínio e que, portanto, é voltada mais à ação, a ponto de se tornar um movimento tanto intelectual como social.

6- Tal visão, portanto, não se insere necessariamente em determinada instituição ou faz uso de uma aplicação teórica exclusiva, e inclui dimensões de liderança, espirituais e materiais em um âmbito obviamente mais amplo do que um planejamento ou análise de políticas, mais baseadas em informações empíricas. 
7- $\quad$ objetivo dos estudos do futuro não é necessariamente o de oferecer controle sobre o futuro ou de buscar maior lucro e poder, como podem ser o do planejamento ou da análise. Estes podem verdadeiramente buscar mudanças não estabelecidas pela administração.

Portanto, podemos perceber que trabalhos atuais envolvendo os estudos do futuro, ainda que permeados por determinada abordagem ou visão, deveriam na verdade privilegiar o conceito defendido por Slaughter em várias de suas obras, que é o de "previdência" 5 (do original foresight), e que, ao envolver qualidades de preparação, capacidade de antever e conjeturar ou ver antecipadamente, nos parece particularmente adequado em mesclar diversas abordagens dos estudos do futuro, em especial dentro da proposta deste trabalho, que é voltada ao ensino de tais habilidades aos jovens. 6

\subsection{FERRAMENTAS PARA O ESTUDO DO FUTURO}

A parte final do capítulo procura mostrar de que maneira esses modelos conceituais sugeriram a criação e /ou utilização de ferramentas específicas para a realização destes estudos. Também fruto da evolução e escopo dos projetos e experimentos realizados nas últimas décadas, a descrição em si de tais ferramentas em constitui elemento importante na realização deste trabalho por três razões principais:

5 A escolha do termo em português reflete os significados da palavra, que combinam a "1. qualidade do que é previdente, 2. previsão do futuro; conjectura e 3. faculdade de ver antecipadamente; antevidência, presciência (Dicionário Houaiss)

Richard Slaughter coordena o Institute or Foresight é autor de diversos trabalhos nos útlimos anos que buscam retomar os estudos do futuro sob uma perspectiva mais ampla e menos segmentalizada, voltadas ao desenvolvimento do que ele chama de "competência futura". 
1- estas ferramentas se tornaram os instrumentos essenciais para a realização destes estudos, a despeito do modelo conceitual escolhido e, ainda que exista uma certa dificuldade em se decidir por determinada abordagem, devido à diversidade de modelos conceituais, determinadas ferramentas podem ser usadas tanto em um como em outro modelo, ou seja, produtos finais podem partir de uma visão especifica, mas são atingidos, mesmo assim, pelo uso de ferramentas comuns;

2- conseqüentemente, estas ferramentas, constituiriam o conjunto básico de conhecimentos a ser adquirido para que os estudantes do Ensino Médio possam fazer uso dos estudos do futuro dentro das atividades já existentes em seus currículos;

3- finalmente, pela possibilidade de que estas ferramentas sirvam também como complemento ao conhecimento oferecido aos estudantes do Ensino Médio, ainda que estas não sejam usadas explicitamente para estudos do futuro.

Nossa pesquisa irá oferecer uma descrição dessas ferramentas que procura combinar trabalhos anteriores, em particular as sistematizações propostas por Kauffman, Jr. (1976), Schultz (1998) e Inayatullah (2005).

I- Teoria de Sistemas: definindo-se um sistema como "um grupo de elementos tão interligados que funcionam como um todo" (Kauffman, p.149), a teoria de sistemas foi proposta em meados de 1950 pelo biólogo Ludwig von Bertalanffy (Bertalanffy,1975) e procurava explicar o funcionamento de sistemas naturais e sociais afirmando que estes são abertos e sofrem interações com o ambiente onde estão inseridos. Tal interação, por sua vez gera realimentações ("feedback") de natureza tanto positiva como 
negativa, resultando em uma auto-regulação regenerativa. Esta, por sua vez cria novas propriedades (benéficas ou maléficas) para o todo, independente das partes. No primeiro caso, as alterações favorecem a sobrevivência do sistema e, no segundo, o seu desaparecimento. A existência de realimentação no sistema o transforma necessariamente em um sistema dinâmico, já que deve haver uma causalidade implícita. Tal causalidade, nesse caso, ganha o termo de causalidade não-linear, já que na maior parte dos sistemas, por exemplo, existem diversos canais de realimentação que impedem que uma causa leve a determinado efeito, mas sim, na verdade, várias causas, lado a lado, como responsáveis pelo mesmo efeito. O trabalho com a teoria de sistemas é de natureza essencial para os estudos do futuro para a melhor compreensão não só de todas as causas e agentes atuando em determinado sistema ou situação, mas também para que alternativas sejam descobertas para tais sistemas, a partir do uso de simulações.

II- Análise de Tendências: normalmente compreendidas como "direções que indicam mudanças sobre uma variável ao longo do tempo de padrões observáveis no mundo social e físico ao nosso redor" (Kauffman, p.79). Muitas vezes, podemos muitas vezes conhecer tais padrões sem mesmo entender as razões por detrás destes. Freqüentemente usada por futuristas, a análise e extrapolação de tendências permitem que especulemos em termos dos extremos de mudança possíveis na variável em questão. O uso de tendências geralmente requer modelagem matemática a partir de algoritmos, usando-se dados quantitativos e os observando à luz de princípios como crescimento exponencial, por exemplo. As tendências costumam ocorrer em "famílias", básicas: a) as coisas permanecem inalteradas; b) as coisas aumentam; c) as coisas 
aumentam, e então atingem um pico ou diminuem; d) as coisas diminuem e; e) as coisas diminuem, e então atingem seu ponto mais baixo ou aumentam. A partir dessas premissas, o trabalho na análise de tendências pode se concentrar, por exemplo na identificação de mega- tendências (aquelas que irão se sobrepor à outras por determinado período); tendências em potencial (aquelas que mostram um crescimento perceptível em determinado período); diversificação de tendências (maneiras através das quais determinada tendência pode se "mesclar", ou subdividir-se em outras); e, talvez de modo mais importante em uma abordagem econômica, por exemplo, o ciclo de vida de determinada tendência, que permitiria a tomada de decisões apropriadas antes do fim de seu ciclo.

III- Identificação de Questões Emergentes: trata-se da percepção da relevância de determinada questão ou situação antes desta se tornar uma tendência. Seriam questões que apresentam pouca probabilidade de ocorrência, mas que, caso ocorressem, trariam um impacto dramático à sociedade. Na maior parte das vezes, são questões nascentes e que poucos reconhecem como tal. Muitas vezes, estes se mostram de natureza tão provocativa ou pouco usual no momento em que surgem que chegam até a parecer "ridículas". Foi o caso, por exemplo, do ambientalismo, termo surgido no fim dos anos 50 e que tornou-se uma tendência mais recentemente, ou mesmo as noções relacionadas ao uso de computadores pessoais ou realidade virtual.

IV- Eventos-surpresa ou "wild cards": representam "quebras" do sistema, ou mudanças cujas causas estão interligadas por diversas 
variáveis, que produzem pouca ou nenhuma mudança até que determinado patamar seja atingido, provocando desequilíbrio e uma reorganização do sistema (um exemplo comum nesse sentido seria a queda do muro de Berlim). Muitas vezes, a modelagem através do uso de computadores pode oferecer indicadores de eventos deste tipo. No entanto, a idéia básica por detrás do evento-surpresa reside na pergunta "E se...?", já que estas nos forçam a desenvolver as implicações prováveis a partir da ocorrência de determinado evento.

V- Previsão: geralmente conhecida como "previsão tecnológica" ou forecasting, tais previsões não pretendem afirmar qual será o futuro, mas sim oferecer uma compreensão de um futuro como possível (e não definitivo), baseando-se em três premissas: a primária, ou seja, aquilo que acontecerá caso as coisas continuem como estão; a secundária, que descreve uma possibilidade que mude o modo como as coisas podem acontecer e, por fim, uma terciária, que é uma afirmação sobre o curso mais provável dos acontecimentos. Tais previsões atendem três critérios básicos: ser clara, ou seja, é realizada com o mínimo de ambigüidade e sobre um período de tempo específico; plausível, no sentido de que sua consistência deve ser explicitada (mesmo que o evento previsto seja bastante improvável, ele deve ainda ser plausível); e, por último, justificada, através de uma argumentação o mais racional possível, de modo a constituir uma ferramenta de persuasão semelhante a outros modelos, teorias ou generalizações empíricas.

VI- "Pós-visão": freqüentemente descrito como backcasting ou "história do futuro", este é um processo de previsão "em reverso": parte-se de uma determinada situação em um determinado momento do 
futuro (por exemplo, a descoberta da cura da AIDS no ano de 2025). Usando-se as mesmas premissas e critérios da previsão, busca-se aqui descrever as maneiras através das quais chegou-se àquela determinada situação.

VII- Grupos de Opinião: uma das abordagens mais antigas do processo de previsão envolve a entrevista de (um) perito(s) em determinado campo de conhecimento e sondar aquilo que estes acreditam que irá acontecer em determinada área. Também conhecida como genius forecasting, tal abordagem na verdade agrupa um diverso número de formatos semelhantes em sua abordagem, dentre os quais os mais conhecidos são: Delphi, diversas rodadas de entrevistas e /ou questionários sobre um determinado futuro a ser investigado são aplicados para a criação de uma convergência de opiniões que levaria a um consenso do grupo de entrevistados; brainstorming ou discussões de grupos, voltadas à geração de diferentes idéias; comissões de peritos, voltadas à solução de determinado problema e, naturalmente, pesquisas de opinião tradicionais. $\mathrm{Na}$ realidade, tais abordagens são muitas vezes combinadas entre si, no intuito de aliar as vantagens de cada formato (pesquisas de opinião tendem a ser menos custosas e menos suscetíveis à questões de personalidade, como no caso de uma comissão, por exemplo).

VIII- Cenários: como uma ferramenta que permite prever o futuro e esclarecer alternativas, o uso de cenários é muitas vezes descrito como a ferramenta favorita dos estudos do futuro, caracterizando uma descrição de vários futuros, em um exercício de imaginação que se utiliza de problemáticas do presente. Tais cenários 
costumam ter quatro dimensões : a primeira é a do Status Quo, presumindo que o presente continuará no futuro (em outras palavras, "mais do mesmo"); a segunda dimensão é a de Colapso, onde o sistema não poderá manter o crescimento continuado ou quando as contradições do status quo levam a um colapso interno; a terceira dimensão é a de retorno ou equilíbrio, que se baseia em uma volta a determinado momento anterior (em outras palavras, "os velhos tempos"); e a quarta dimensão é a de transformação, onde mudanças fundamentais de caráter espiritual, tecnológico, político ou econômico podem ocorrer. Ao permitir que sejam feitas relações de caráter histórico interpretativo ( e não necessariamente objetivo), os cenários podem se tornar uma ferramenta visionária poderosa, já que aqueles que os utilizam podem ganhar uma compreensão daquilo que querem para o futuro e não somente de como ele poderá ser. Assim, não apenas prevêem o futuro, mas tornam-se mais capazes de criá-lo.

\subsection{CONCLUSÃO}

Pudemos verificar que a preocupação com os eventos futuros parece ser mais ou menos inerente à experiência humana. $\mathrm{Na}$ antiguidade, nossos ancestrais já buscavam formas de "antecipar" seu destino, levados a isso por questões de planejamento, segurança ou estabilidade. Em meio a um século marcado por mudanças profundas (e, no caso das grandes guerras, de caráter inesperado), a abordagem de caráter divinatória de outros tempos começou a ser substituída por outras abordagens, mais sistematizadas em epistemologias de outras ciências (também em desenvolvimento): surgem então os primeiros estudos do futuro de caráter mais sério, voltados a apontar possíveis caminhos 
ou alternativas para o desenvolvimento das sociedades no pós-guerra.

Em semelhança a essas outras ciências, porém, estes estudos enfrentaram (e ainda enfrentam) obstáculos no sentido de serem aceitos como "ciência" ou "arte", possivelmente derivados da própria visão almejada de futuro exibida pelos profissionais da área. O principal dos obstáculos enfrentados para sua aceitação diz respeito ao seu objeto de estudo, uma vez que o futuro ainda "não aconteceu". No entanto, profissionais do setor alegam que o estudo de fatos históricos do passado também é feito através da interpretação de registros, uma vez que o passado "já aconteceu" e não pode ser reproduzido, como outro fato científico, por exemplo.

Essa dicotomia aparentemente existente entre as abordagens parece mais obscurecer a qualidade dos trabalhos realizados do que realmente apontar para uma de suas vantagens inegáveis: a criação de uma consciência (ou discurso futuro, segundo Slaughter), que nos permita não só compreender o passado e o presente dentro de uma ótica voltada ao futuro, mas também conceber alternativas para este futuro e nos preparar para o desenvolvimento desta ou aquela alternativa e não conceber um futuro apenas, inevitável e inescrutável por definição. Nesse sentido, estudar o futuro iria além da proposição de políticas sociais ou da previsão tecnológica voltada a setores da economia, por exemplo. Os conceitos e ferramentas utilizados nessa tarefa, sejam eles grupos de opinião, análise de tendências, cenários, forecasting e backcasting, ou compreensão de como diferentes tipos de sistemas funcionariam para aumentar nossa compreensão de diversas forças que atuam para transformar o presente em futuro, no sentido de entendê-lo, moldá-lo e, acima de tudo,transformá-lo. 


\section{INOVAÇÃO CURRICULAR NA EDUCAÇÃO BRASILEIRA}

\subsection{INTRODUÇÃO}

Este capítulo serve dois propósitos principais. Em primeiro lugar, apresenta um breve panorama histórico das diferentes fases da educação brasileira, desde a fundação da nação, com um foco particular nos estágios correspondentes ao Ensino Médio atual. Em segundo lugar, colocaremos a questão da inserção dos estudos do futuro dentro desse mesmo nível, como parte de um processo de inovação curricular que, acreditamos, não é de todo incompatível com o sistema educacional brasileiro atual.

Dentro desta proposta de adoção do ensino do futuro nas escolas de Ensino Médio, uma observação precisa ser feita no que tange ao panorama histórico apresentado aqui: o escopo deste trabalho não ignora que tal análise possa carecer de detalhamento minucioso dos vários aspectos relacionados às mudanças na educação brasileira ao longo dos quinhentos anos de nossa história. Outrossim, o que nos interessa primeiramente é a dicotomia entre a percepção de "tradição pedagógica brasileira" (e os paradigmas decorrentes desta) e uma perspectiva de ruptura quase que constante, já que as mudanças observadas na história da educação brasileira foram geralmente causadas pela ruptura com determinado modelo administrativo adotado pelo país. Para isso, iniciaremos a discussão com uma breve exposição de alguns paradigmas pertinentes não só a educação brasileira, mas à atividade educacional em geral. Tal exposição se mostra relevante não só ao fornecer subsídios para a melhor compreensão dessas mudanças e rupturas na história da educação no Brasil, mas também para fundamentar a sugestão da inclusão dos estudos do futuro no Ensino Médio brasileiro, considerando-se tanto nossa tradição pedagógica quanto os paradigmas prevalecentes na educação atual.

Ainda, procuraremos mostrar que a educação no Brasil, como responsabilidade do estado, fica por vezes demasiado dependente de processos 
de reforma curricular, através de decretos e leis possuidores de um caráter 'vertical' e impositivo, o que muitas vezes pode ocasionar uma lacuna na percepção dos profissionais de ensino em relação à natureza e direcionamento de seu trabalho, percepção esta que, por conseqüência, pode acabar sendo transmitida aos aprendizes. Dessa forma, como 'pacientes' do processo tanto professores como aprendizes muitas vezes não conseguem 'transformar' a educação e os conteúdos aprendidos a partir de suas próprias necessidades e interesses. Tais transformações poderiam ocorrer através de processos de inovação curricular, o que, acreditamos, ofereceria um caminho não só mais rápido para mudanças na educação, mas também mais eficaz e individualizado, o que permitiria, em particular, a adoção dos estudos do futuro nas escolas brasileiras de Ensino Médio sem a necessidade de sua introdução a partir de uma nova reforma curricular (o que, por si só, talvez causasse ainda mais incerteza).

Esta transformação ou re-direcionamento de abordagem, por sua vez, não prescinde da estrutura atual e sim a complementa de forma a oferecer alternativas práticas para o trabalho educacional sugerido na última reforma curricular, por exemplo, que outorga relativa autonomia às instituições e estabelece parâmetros curriculares nacionais que sirvam de elemento de coesão dos conteúdos curriculares. A nosso ver, o trabalho com tais parâmetros proporciona um terreno fértil para 0 trabalho e desenvolvimento de práticas relacionados aos estudos do futuro.

\subsection{DA NATUREZA DA EDUCAÇÃO E SEUS PROCESSOS}

Os processos sócio-econômicos e políticos fazem com que os indivíduos sejam conduzidos a se comportarem de diversas maneiras no aspecto físico, afetivo, social, cognitivo e moral, ao estabelecermos relações com os outros 
membros de nossa sociedade. Contudo, juntamente com esse aprendizado informal ocorre aquele que é desenvolvido sistematicamente, a partir de planos, objetivos, conteúdos e meios previamente traçados: a escola é a agência por excelência da educação formal (Piletti, 2006, pp.9-10). Cabe aqui ressaltar, no entanto, que existe uma simultaneidade de aprendizados ocorridos no mundo "informal" e no "formal", representado pela escola, que não só permite dentro de si tanto um (via o relacionamento com os colegas e professores) como outro (via a transmissão direta de conteúdos).

A educação formal, por sua vez, pode ser dividida em duas abordagens distintas, processo e produto, respectivamente, e esta dicotomia tradicionalmente é motivo de discussão: de modo geral, a primeira privilegiaria a aplicação de conteúdos na resolução de problemas ou na compreensão de processos históricos, geográficos e científicos, por exemplo. A segunda favoreceria a assimilação de informações, sem necessariamente contemplar seu possível uso.

Naturalmente, seria simples concluir que a abordagem de processo na educação seria mais compatível com a pedagogia e didáticas modernas, mas mesmo assim, processos e produtos do conhecimento podem coexistir na educação, uma vez que não existe um sem o outro. Um equilíbrio entre os dois permitiria que o aprendiz não tratasse o aprendizado somente como um produto pronto e acabado que deve ser reproduzido da mesma forma e sim como uma mistura entre este produto e seu processo, para que o aprendiz possa também auto-educar-se. (Piletti, pp.10-11)

Essa aparente dicotomia entre processo e produto sugere ainda outra, a da educação como meio e da educação como fim. Mais uma vez, parece relevante ressaltar que ambas as direções podem e precisam co-existir em equilíbrio: determinados fins (teorias e práticas sociais determinadas) pressupõem o uso de determinados meios (métodos de ensino somados a recursos materiais e humanos) e ambas não podem prescindir uma da outra: de que adiantaria utilizar diversos meios para atingir objetivos educacionais sem uma visão maior? e, também, de que adiantaria uma visão maior sem a oferta de 
recursos que a viabilizem?

Assim, a superação dialética dessas oposições mostra-se de vital importância na manutenção do dinamismo do processo educacional. Não nos parece suficiente apenas reproduzir modelos e paradigmas, uma vez que a sociedade brasileira atual encontra-se em constante processo de mudança. Os processos de reprodução, crítica e criação parecem ser inerentes ao desenvolvimento pessoal e social e esta superação, ainda que provisória, exige a formulação de outras sínteses, outros focos de oposição, outras alternativas que orientem pensamentos e ações:

Trata-se, certamente, de uma atitude antieducativa aquela que se limita a reproduzir o passado, mas esta reprodução não deixa de ser a base da crítica e da criação (....) O processo educacional é dinâmico. Cabe-lhe estimular as novas gerações a construir um futuro melhor com base no conhecimento crítico da história.(Piletti, p.16)

\subsection{O BRASIL COLONIAL}

Proclamavam os europeus aqui chegarem para expandirem nestas plagas o cristianismo, mas na realidade, movia-os o propósito de exploração e fortuna. A história do período colonial é a história desses dois objetivos a se ajudarem mutuamente na tarefa real e não confessa da espoliação continental. A vida do recém-descoberto continente foi, assim, desde o começo, marcada por essa duplicidade fundamental: jesuítas e bandeirantes; 'fé e império'; religião e ouro. (...) Nascemos assim, divididos entre propósitos reais e propósitos proclamados. (Texeira, 1962, p.59)

Os jesuítas foram responsáveis por, praticamente, dois séculos da educação brasileira e assim, tiveram importância decisiva na formação de uma tradição pedagógica brasileira. Estes chegaram ao Brasil em 1549, e rapidamente espalharam-se pelas várias regiões brasileiras, primeiro ao sul e depois para o norte.

Parte da Companhia de Jesus, fundada por Inácio de Loiola em 1534, 
atuavam em reação ao movimento protestante na educação de novas gerações e na ação missionária, na conversão à fé católica dos povos das regiões em processo de colonização. No Brasil, a seu trabalho religioso era somado o trabalho educativo no ensino das primeiras letras e gramática latina, ensino este que perpetrava não só a doutrina católica como os costumes europeus.

O trabalho educacional e de catequese dos jesuítas incluía não só os índios mas também os filhos de senhores de engenho e de colonos, além dos negros escravos. Dotados de grande capacidade de adaptação, aprendiam e ensinavam linguagens indígenas nos colégios (por exemplo, José de Anchieta escreveu a primeira Arte da Gramática da Língua mais usada na costa do Brasil, o tupi), e por vezes, se valiam de órfãos portugueses para atrair mais facilmente as crianças indígenas e, por fim, chegarem a seus pais. A estrutura curricular da Companhia de Jesus era descrita em um plano chamado Ratio Statorum. Ao término dos cursos de nível secundário, os jovens que não se interessassem por uma carreira eclesiástica deveriam continuar seus estudos na Europa (por exemplo, em cursos de direito em Coimbra, Portugal). (Carvalho, 1978)

As reformas instituídas na administração da colônia pelo Marques de Pombal (primeiro-ministro de Portugal entre 1750 e 1777) voltadas à centralização da administração e maior controle da colônia (por exemplo, pondo um fim às capitanias hereditárias e elevando o Brasil à condição de vice-reinado com a mudança da capital de Salvador para o Rio de Janeiro) entraram em conflito com os jesuítas e deste conflito surge a primeira ruptura na história da educação brasileira: as escolas jesuíticas foram suprimidas e em seu lugar foram criadas aulas régias de Latim, Grego e Retórica, na criação de um sistema "que não mais servisse a fé mas sim ao Estado, e sem a mesma eficiência em sua organização". (Carvalho, p.116)

O ensino brasileiro passaria a ser administrado por uma Diretoria de Estudos (que a rigor, só começou a operar, após o afastamento de Pombal) e cada uma dessas aulas régias era uma unidade de ensino, com professor único, autônoma e isolada, sem pertencer a qualquer escola e sem tampouco exibir um 
currículo organizado e hierarquizado com duração prefixada ou seqüenciada, permitindo que os alunos se matriculassem em tantas quantas "aulas" desejassem. Em contraste com a excelência de formação dos professores jesuítas, os novos professores eram de baixo nível, resultado da baixa remuneração e da improvisação, nomeados sob concordância de bispos, tornando-se 'proprietários' de suas aulas régias, atribuídas a eles vitaliciamente, como um titulo de nobreza (Chagas, 1980).

Em 1772, após a criação de um imposto para o ensino (o "subsídio literário"), foi instituída, em vários pontos do país,uma nova estrutura curricular que, ao ignorar a estrutura estabelecida pelos jesuítas, pouco oferecia em termos de inovação, limitando-se à atribuição ou redistribuição de conteúdos (ver Tabela 1).

Dentro dos seminários, contudo, uma estrutura escolar propriamente dita semelhante a dos jesuítas foi mantida, em termos de seqüência lógica e duração determinada, formação de classes e planos de ensino, em marcado contraste com o novo sistema público, desmantelado e desorganizado.

\subsection{O BRASIL IMPERIAL}

Como resultado das diversas mudanças ocorridas na Europa ao final do século XVIII e durante o século $X X^{7}$, o Brasil colônia se viu palco de uma mudança que provocaria mudanças profundas em sua história. Ao escapar das guerras napoleônicas e se transferir para o Brasil com seus 15 mil funcionários, a Corte Portuguesa faz do Brasil o centro da coroa portuguesa e, por conseguinte,

\footnotetext{
$7 \quad$ Entre as quais podemos destacar: o processo de independência americano (1776); a tomada do poder pela burguesia na França (1789); o avanço da Revolução Industrial; o surgimento de grandes cidades e do proletário e o desenvolvimento das ciências humanas tais como História, Sociologia, Psicologia e Antropologia (Cronologia das Civilizações, Editora Abril, 1979 São Paulo)
} 
a educação no país recebe um novo direcionamento, sem no entanto, abandonar características existentes até então. Como resultado, ao final do século XIX, mostrávamos, por um lado, a extensão dos níveis de ensino oferecidos no país, e por outro, uma maior desorganização do sistema como um todo.

De certa forma, o objetivo das reformas pombalinas passou a ser concretizado, mas somente no que diz respeito ao ensino superior, uma vez que tal objetivo pareceu tornar mais explícito a formação de elites dirigentes. Assim, Dom João criou diversos cursos:

- Academia de Marinha (1808), Academia Real Militar (1810); cursos de Anatomia e Cirurgia (1808), laboratório de Química (1812), curso de Agricultura (1814), Escola Real de Ciências, Artes e Ofícios (1816), no Rio de Janeiro;

- curso de Cirurgia (1808), cadeira de Economia (1808), curso de Agricultura (1812), curso de Química (1817), curso de Desenho Técnico (1817). (Piletti, p.42)

Após a proclamação da Independência, dois cursos de Ciências Jurídicas e Sociais foram somados àqueles criados por Dom João, surgindo as primeiras Faculdades de Direito do Brasil, uma no Convento de São Francisco e outra no mosteiro de Olinda, ambas fundadas em 1828, aproximadamente um ano após o decreto que as criou, datado de 11 de agosto de 1827.

Por outro lado, o ensino das primeiras letras foi alvo de poucas iniciativas, sendo que somente em 1823 foi promulgado um decreto onde se estabelecia uma escola no Rio de Janeiro, com apenas um professor e, para cada decúria (grupo de dez alunos), haveria um decurião (aluno "assistente" ou mais competente) que ensinaria os demais, em uma réplica do conhecido método Lancaster, ou seja, "Aquele que ensina, aprende"8 (The Lancasterian Monitorial

$8 \quad$ Tal metodologia defendida em obras como Sistema Monitorial (1798) e Melhorias na Educação (1803) e promovida através de palestras dadas pelo autor não era particularmente original e sim uma adaptação das idéias de Andrew Bell em seu sistema Madras de educação, consistindo na transmissão de aprendizado recém adquirido de um aluno para outro, o que 
System of Education, 2007)

A primeira Constituição de 1824 estabelecia em seu artigo 179 que "a instrução primária é gratuita a todos os cidadãos" (Chagas, p.16). Três anos depois, outra lei determina a criação de escolas de primeiras letras em todas as cidades, vilas e vilarejos e escolas de meninas nas cidades mais populosas (dispositivos que nunca chegaram a ser cumpridos). Mais tarde, em 1854, o ensino primário é dividido em elementar e superior, com o ensino de instrução moral e religiosa, leitura e escrita, noções básicas de gramática, de aritmética e sistemas de pesos e medidas no primeiro nível e outras dez disciplinas desdobradas do nível elementar no segundo.

As aulas régias características do período pré-imperial disseminaram-se mais ainda e ganharam a função de preparar estudantes para o ingresso nos cursos superiores, cursos estes de formação profissional isolada. O Ato Adicional de 1834 confere às províncias o direito de legislar sobre a instrução pública e estabelecimentos próprios a promovê-la, excetuando as Faculdades de Medicina e os cursos jurídicos, fazendo com que o poder central atuasse somente em relação ao ensino superior, em detrimento do ensino secundário, (e, por extensão, do técnico-profissional) e do ensino normal. (Haidar, 1972, p.17)

Em relação a este último, fica evidente a pouca atenção dada à formação de professores. Até a década de 1830, com a criação das primeiras escolas normais no Rio de Janeiro e Bahia, os professores eram selecionados com base em sua maioridade, moralidade e, por fim, capacidade, esta às vezes objeto de concurso. Foi somente em 1875, segundo Piletti (2006, p.44) no entanto, graças ao aparente fracasso destas primeiras escolas, que duas escolas normais (uma para cada sexo) foram instituídas no Rio de Janeiro, sendo que após sua transformação em escola única, pode-se afirmar que as escolas normais reter as características de punição corporal e os baixos resultados típicos do período em que foi desenvolvido e que levaram o método a cair em desuso. 
começaram realmente a se desenvolver. A estrutura do ensino normal abrangia matérias relacionadas à função docente (além do ensino secundário característico), geralmente ligadas às áreas de Direito, Economia Doméstica, Agricultura e Pedagogia, incluindo também a Caligrafia, Desenho, Música Vocal, Costura (para as meninas), Ginástica e Prática Manual (para os meninos). Os ingressantes deveriam ter ao menos 16 anos de idade e passar o exame de admissão ao nível de escola primária elementar. A duração abrangia seis séries (1880), quatro séries (1881) e três (1888) e o curso, oferecido no período noturno (o que, naturalmente, invalidava a prática de ensino da cadeira de Agricultura). (Chagas, p.24)

Um dos efeitos do Ato Adicional também foi a criação, por parte das províncias, dos liceus provinciais, na realidade constituídos inicialmente mais pelo ajuntamento de aulas dispersas do que por uma estrutura organizada e hierárquica. Os primeiros datam de 1835 (o Ateneu do Rio Grande do Norte) e de 1836 (liceus da Bahia e Paraíba).

No Rio de Janeiro, em 1837, um decreto transforma o Seminário de São Joaquim no Colégio de Pedro II. Desta vez, os estudos mostram-se organizados de forma seriada e orgânica, e os estudantes que os concluíam ganhavam o titulo de bacharel em letras e direito a ingresso em cursos superiores sem necessidades de exames. Desde sua fundação, o Colégio de Pedro II sofreu oito reformas em seus estatutos (1841, 1855, 1857, 1862, 1870, 1876, 1878, 1881).

A duração do curso, no ano de seu último estatuto (1881) era de sete anos (ver Tabela 1). Analisando a carga horária das disciplinas, veremos uma ordenação média onde lideram a Comunicação e Expressão (60\%); seguidas por Matemáticas e Ciências (20\%) e Estudos Sociais (17\%) e outras atividades (3\%), mostrando uma predominância no estudo de Humanidades nos currículos do Império. (Piletti, p.47)

Uma das razões que poderiam explicar a falta de atenção aos níveis primário, secundário e normal no Brasil imperial era a ausência de necessidade 
de conclusão de quaisquer destes no ingresso ao ensino superior, cujas exigências limitavam-se à comprovação de determinada idade e à aprovação em seus exames específicos. Assim, o sistema organizado dos liceus provinciais e do Colégio de Pedro II coexistiu ao lado do sistema inorgânico de aulas e cursos preparatórios. A fragmentação do ensino secundário chegou a tal ponto de até mesmo uma escola 'modelo' como o Colégio de Pedro II acabar (vide o número de reformas em seus estatutos) adotando o sistema de aulas avulsas, já que seus alunos constituíam uma média de $10 \%$ em relação aos alunos de outros estabelecimentos mostrando que, para alcançar os estudos superiores, o caminho mais rápido não passava pelo Pedro II. Analisando as poucas informações estatísticas disponíveis em relação ao período Imperial, podemos concluir que dentro de uma população de quase 14 milhões de habitantes, apenas 300 mil (cerca de $15 \%$ ) estavam matriculados em escolas. (Piletti, p.47)

Ao final do Império, não existia ainda um sistema integrado de ensino: os cursos careciam de organização e hierarquização; o acesso a determinado nível prescindia da conclusão de outro; o ensino primário mostrava a pouca preparação dos professores primários em virtude da ausência de escolas normais; o ensino secundário era vítima da dualidade de sistemas existentes e, finalmente; possuíamos escolas isoladas de nível superior mas ainda não tínhamos uma universidade.

\subsection{DA PRIMEIRA REPÚBLICA AO ESTADO NOVO}

Além da óbvia importância para nossa história atual, a proclamação da República em 1889 marca também um momento particularmente interessante dentro da abordagem adotada neste trabalho, uma vez que, possivelmente pela primeira vez, são divulgadas em caráter nacional uma série de ideais, dentro da visão republicana de administração, que alimentam projetos para o futuro do 
Brasil: a promoção do progresso e independência cultural e a convivência social de todos os brasileiros sob a égide de uma federação democrática.

Em contrapartida a estes ideais, outros fatores ${ }^{9}$ acabaram por levar à Revolução de 1930, que, se por um lado mostraria diversas conquistas em termos sociais e democráticos, por outro abriria caminho também para o golpe que levou ao Estado Novo. Dessa forma, apesar das poucas mudanças em relação à herança educacional deixada pelo Império, a primeira República foi pródiga na discussão de vários princípios educacionais que acabariam por ser adotados no período seguinte, uma vez que vários dos educadores que participaram ativamente de sua discussão ao final da Primeira República passaram a fazer parte do governo após a Revolução de 30 e efetivaram tais princípios na Constituição de 1934:

i. gratuidade e obrigatoriedade do ensino de $1^{\circ}$ grau;

ii. direito de todos à educação, que aparece pela primeira vez na Constituição de 1934, artigo 149 "a educação é direito de todos";

iii. liberdade de ensino, seja ela compreendida como o "livre exercício de qualquer profissão moral, intelectual e industrial" (Constituição de 1891, art. 72 §24) ou a autonomia relativa das instituições educativas expressa na "liberdade de ensino em todos os graus e ramos, observadas as prescrições da legislação federal e estadual" (Constituição de 1934, art. 150), ou de modo mais genérico, na independência de opinião e livre manifestação do pensamento;

iv. obrigação do Estado e da família no tocante à educação, que condicionava a aplicação de recursos provenientes de impostos na organização e manutenção de sistemas educativos;

\footnotetext{
$9 \quad$ Entres estes podemos citar a centralização do poder ilustrada pelo coronelismo e pela "dieta do café com leite"; a corrupção dos processos eleitorais (e sua exclusividade aos homens maiores de 21 anos); a exploração econômica da classe média e do proletariado; a dependência econômica do café no mercados internacionais e a dependência cultural em relação aos modelos europeus, o que resultou na Semana de Arte Moderna de 1922, em uma tentativa de propor uma cultura brasileira autêntica. Nosso Século. Abril Cultural. São Paulo. 1980
} 
v. ensino religioso de caráter multiconfessional, indicando que, após a separação de Igreja e Estado observada na proclamação da República e efetivada através da instituição do ensino leigo na Constituição de 1891 (art 71 §6º), este é re-introduzido sendo de "freqüência facultativa e ministrado de acordo com os princípios de confissão religiosa do aluno, manifestada pelos pais ou responsáveis (Constituição de 1934, art. 153). (Piletti, p.55-60)

Tanto sistemas e competências educacionais continuaram a coexistir, já que as decisões do Ato Adicional de 1834 foram consagradas em 1891, com os Estados responsáveis pela instrução primária e a União responsável principalmente pelo superior. No caso do ensino secundário, sua atuação limitava-se basicamente ao Distrito Federal, ou seja, na manutenção do Colégio de Pedro II, não só não criando outros estabelecimentos em outros estados como também extinguindo aqueles mantidos pelo Governo Federal.

A dualidade dos sistemas secundários fica ainda evidente na divisão dos Poderes que o regulamentavam: o regime parcelado era "protelado" pelo Poder Legislativo (atendendo a interesses particulares) e o regime regular era regulamentado pelo Poder Executivo (explicado pelo fato do Congresso Nacional ter abdicado de sua responsabilidade de legislar sobre o ensino). Em ambas as modalidades, tal legislação mostrava-se importante porque o controle e regulamentação do acesso ao ensino superior efetuado pelo Governo Federal forçava a adequação dos cursos de ensino secundário e, ao equiparar-se às normas adotadas pelo Colégio de Pedro II, formandos de outros estabelecimentos teriam os mesmos direitos de acesso a cursos superiores sem prestação de novos exames.

Assim, listamos brevemente os objetivos das cinco reformas principais promovidas pelo Poder Executivo, que atingiram tanto o ensino secundário como o superior (já que o primeiro era visto como ferramenta de acesso ao segundo) e as diferentes durações dos cursos durante a Primeira República: 
i. instrução secundária e fundamental de jovens para ingresso nos cursos superiores e para o bom desempenho dos deveres do cidadão (curso de 7 anos, efetuada em 1890 por Benjamin Constant);

ii. proporcionar cultura intelectual necessária para a matricula nos cursos de ensino superior e obtenção do grau de bacharel em Ciências e Letras (curso de 6 anos, efetuada em 1901 por Epitácio Pessoa);

iii. proporcionar cultura geral de caráter essencialmente prático, difundir o ensino das ciências e das letras, libertar o ensino da preocupação subalterna do curso preparatório (Externato, 6 anos; Internato, 4 anos efetuada em 1911 por Rivadávia Correia);

iv. ministrar sólida instrução fundamental para habilitar estudantes a prestar exames vestibulares ( 5 anos efetuada em 1915 por Carlos Maximiliano);

v. fornecer base indispensável para a matrícula no ensino superior, preparo fundamental para a vida e a cultura média geral do país (certificado de aprovação em 5 anos; bacharelado em Ciências e Letras em 6 anos, efetuada em 1915 por Carlos Maximiliano). (Chagas, p. 27)

Em contraste com o período Imperial, houve uma redução na carga horária destinada às Humanidades (41,2 \%) e Estudos Sociais (13,3\%) em favorecimento de Matemática e Ciências (27,3\%) e outras atividades (18,2\%).

O ensino superior viu o surgimento, no Estado de São Paulo, da Escola Politécnica (1896), da Escola Superior de Agricultura de Piracicaba (1905) e da Faculdade de Medicina (1913). O ensino normal, voltado à formação de professores, ganhou o que poderia ser chamada de uma marcada separação em relação ao ensino secundário no período anterior a Revolução de 1930. Estes deveriam freqüentar o curso primário, seguido de um curso complementar, e depois freqüentar o curso normal. A abolição do curso complementar e sua 
unificação com o ginásio permitiram que o curso normal se tornasse um curso de segundo ciclo de caráter especificamente pedagógico (Antunha in Brejon, 1973, pp.54-57).

Os diversos ajustes e reformas ocorridos no sistema de ensino brasileiro mostram, por um lado, a dificuldade de integração dos esforços da nação como um todo em promover uma maior organização do ensino. Também evidenciam, por outro lado, a qualidade da discussão ocorrida nesse período, sobretudo na década de 20. À fundação da Associação Brasileira de Educação (ABE) em 1924, e ao inquérito sobre a educação promovido pelo jornal O Estado de São Paulo somaram-se outras reformas educacionais realizadas por outros Estados, já que a responsabilidade pelo ensino primário e para o ainda incipiente ensino técnico-profissional (destinado a cegos, surdo-mudos e menores abandonados do sexo masculino, segundo o art. 28 do Decreto no 16 782-A de 13-01-1925) era quase exclusivamente destes ${ }^{10}$.

Segundo Piletti (1982, p.112), a reforma de maior repercussão foi a de Fernando Azevedo no Distrito Federal em 1928, que defendia o uso de três princípios no processo:

i. estender a acessibilidade do ensino, reduzindo o ensino primário de 7 para 5 anos; redistribuindo os professores excedentes; criando um segundo turno caso o número de matriculados excedesse a lotação do prédio; construindo grandes grupos escolares;

ii. articular a educação pública dentro de um plano único e sistemático: - 5o ano primário tornou-se um ano de transição ao curso vocacional; cursos complementares passaram a funcionar anexos à escolas e institutos profissionais, o que ligaria o ensino primário ao técnico-profissional;

10 Destacam-se entre elas, a de Sampaio Dória, (São Paulo, 1920); a de Lourenço Filho (Ceará, 1923); a de Anísio Teixeira (Bahia, 1925); a de Francisco Campos e Mário Cassamanta (Minas Gerais, 1927) e a de Fernando Azevedo (Distrito Federal, 1928), ver Nelson Piletti, História da Educação no Brasil, Série Educação p:62-65 
iii.

a. adaptar o ensino ao meio através de oficinas e pequenas indústrias (urbano), de campos de experiências agrícolas (rural) e de museus e oficinas de aparelhos de pesca (marítimo);

b. adaptar a escola à "educação nova": em primeiro lugar oferecendo uma educação inicial uniforme; na formação para o trabalho e para vida em cooperação dentro da comunidade. (Lourenço Filho, s.d.)

O trabalho de educadores como Fernando de Azevedo, acabou por disseminar idéias para um sistema de ensino genuinamente brasileiro e, em 1931 levou o governo a convidar educadores a auxiliá-lo na elaboração de uma política nacional de educação, o que, por sua vez, resultou na criação do Ministério de Educação através do qual o Governo tentava ampliar sua faixa de participação no desenvolvimento da educação nacional e desenvolver instrumentos de unificação e disciplina para integrar sistemas estaduais isolados, através do estabelecimento de mecanismos de intervenção e atuação das Secretarias de Educação junto às escolas (Antunha in Brejon, pp.54-57). ${ }^{11}$

Esse esforço de construção de um sistema nacional de educação, por outro lado, marcou o início de um processo de centralização das competências, com redução da autonomia dos Estados e o surgimento de um caráter 'normativo' e burocrático.

O governo que assumiu o poder após a Revolução de 30 efetuou mudanças estruturais no ensino, começando a reforma pelos ensinos secundários e superior, e deixando o ensino primário, normal e técnico-científico para a década seguinte.

\footnotetext{
11 Um dos resultados da conferência de educação da Associação Brasileira de Educação de 1931 foi a redação do Manifesto A Reconstrução Educacional do Brasil- Manifesto dos Pioneiros da Educação Nova.
} 


\begin{tabular}{|c|c|c|c|}
\hline $\begin{array}{c}\text { ESTRUTURA CURRICULAR } \\
\text { JESUITTA }\end{array}$ & $\begin{array}{c}\text { REFORMA } \\
\text { POMBALINA (1772) }\end{array}$ & $\begin{array}{l}\text { ESTRUTURA CURRICULAR DO } \\
\text { COLÉGIO D. PEDRO II (1881) }\end{array}$ & ESTRUTURA APÓS A REVOLUÇÃO DE 1930 \\
\hline $\begin{array}{l}\text { 1. Ensino Primário: aulas elementares } \\
\text { de ler e escrever; } \\
\text { 2.Ensino Secundário: } \\
\text { a) cursos de Letras Humanas, } \\
\text { composto de três classes de ensino de } \\
\text { gramática: ínfima, média e suprema, } \\
\text { seguidos por estudos na área de } \\
\text { Humanidades, envolvendo História } \\
\text { Poesia e Retórica com duração média } \\
\text { de } 5 \text { ou } 6 \text { anos; } \\
\text { b) cursos de Filosofia e Ciências, } \\
\text { composto de estudos de Lógica, } \\
\text { Metafísica, Moral, Matemática, e } \\
\text { Ciências Físicas e Naturais com } \\
\text { duração que chegava a } 3 \text { anos. } \\
\text { 3. Ensino Superior: cursos de Teologia } \\
\text { e Ciências Sagradas: destinado à } \\
\text { formação de sacerdotes. }\end{array}$ & $\begin{array}{l}\text { iii. seis aulas de } \\
\text { Retórica; } \\
\text { iv. três aulas de } \\
\text { língua grega; } \\
\text { v. três aulas de } \\
\text { Filosofia. }\end{array}$ & $\begin{array}{l}\text { 1ํ ano: História Sagrada, Português, } \\
\text { Geografia, Aritmética e Geometria; } \\
\text { 2º ano: Português, Francês, Latim, } \\
\text { Geografia, Matemáticas Elementares; } \\
\text { 3o ano: Português, Francês, Latim, } \\
\text { Geografia, Matemáticas Elementares, } \\
\text { Aritmética e Álgebra; } \\
\text { 4o ano: Português, Francês, Latim, } \\
\text { Geografia, Cosmografia Matemáticas } \\
\text { Elementares; } \\
\text { 5o ano: Português, Inglês, Latim, História } \\
\text { Geral, Física e Química; } \\
\text { 6o ano: Alemão, Grego, História Natural e } \\
\text { Higiene, Retórica Poética e Literatura } \\
\text { Nacional, Filosofia; } \\
\text { 7o ano: Italiano, Alemão, Grego, Português } \\
\text { e História Literária, Filosofia, Corografia } \\
\text { (Cartografia) e História do Brasil. }\end{array}$ & $\begin{array}{l}\text { Curso fundamental de cinco anos, de formação geral; } \\
\text { Humanidades: Português, Francês, Inglês, Latim e Alemão; } \\
\text { Matemática e Ciências: Matemática, Ciências Físicas e } \\
\text { Naturais, Física, Química e História Natural; } \\
\text { Estudos Sociais: História da Civilização e Geografia; } \\
\text { Outras atividades: } \\
\text { Desenho e Música; } \\
\text { Curso complementar (ou pré-universitário) de dois anos } \\
\text { com ênfase nas matérias de: } \\
\text { Humanidades (para os cursos jurídicos); } \\
\text { Ciências Naturais e Biológicas (para os cursos de Medicina, } \\
\text { Farmácia e Odontologia); } \\
\text { Matemática (para os cursos de Engenharia e Arquitetura). }\end{array}$ \\
\hline
\end{tabular}

Tabela 1- Mudanças nas Estrutura Curricular do Ensino Brasileiro (1) 
Nessa nova estrutura, a formação geral do aluno ganhou maior importância, ao lado da preparação para o ensino superior nos novos objetivos do ensino secundário (ver Tabela 1). A divisão de tempo mostra uma redução da carga na área de Humanidades $(29,1 \%)$; um aumento desta nas áreas de Matemática e Ciências (33,3\%); outro aumento na área de Estudos Sociais $(20,8 \%)$; e por fim, outro aumento na oferta de outras atividades $(16,8 \%)$, na forma de Desenho e Música.

Outra importante herança desse período foi a criação da Universidade de São Paulo, em 25 de janeiro de 1934, uma vez que até aquele momento, Brasil e Paraguai ainda eram os dois únicos paises da América do Sul que ainda não possuíam uma ${ }^{12}$.

\subsection{O ESTADO NOVO E A REPÚBLICA POPULISTA}

Getúlio Vargas fecha a Câmara e Senado em 10 de novembro de 1937, tornando-se o ditador da nação, pondo fim a um processo de repressão dos movimentos comunistas do período (ainda que o mais famoso destes, o Plano Cohen, tenha sido elaborado pelos próprios integralistas para justificar o golpe). Com sua ascensão ao poder, Getúlio promulga nova Constituição atribuindo a ele poderes quase plenos. (Nosso Século, 1980)

Entre os aspectos mais destacados da nova Constituição de 1937 destacam-se a remoção da menção explícita do direito de todos à educação e somente uma garantia de que esta seria oferecido à infância e juventude que não possuíssem recursos para a educação em instituições particulares. A obrigatoriedade e gratuidade do ensino primário foram mantidas, mas contribuições mensais são sugeridas para aquele que tiverem recursos. O Estado

12 Em virtude da outorga de título de Doutor Honoris Causa ao Rei Alberto I da Bélgica, foi criada a Universidade do Rio de Janeiro em 7 de setembro de 1920. Contudo, sua existência era nominal, pois seus cursos continuavam com administrações isoladas. ver Heládio Antunha C.G. Universidade de São Paulo: Fundação e Reforma, São Paulo, CRPE., 1974 p. 53, nota 1.) 
vê como seu dever educacional maior o ensino pré-vocacional destinado às classes menos favorecidas, o que, se por um lado era um avanço democrático, por outro poderia pressupor dois tipos de educação, a destinada às classes populares e outra destinada às elites. (Piletti, 2006, pp.87-91)

No primeiro caso, a regulamentação veio em janeiro de 1946 pelo Decretolei oㅡ 8530 (após a queda de Vargas), mas sua elaboração é anterior. Ao ensino primário eram dadas as finalidades de proporcionar a iniciação cultural, formar e desenvolver a personalidade e elevar o nível de conhecimento necessário à vida em sociedade (em termos de família, saúde e trabalho). Uma mudança importante foi a divisão do ensino primário em duas categorias:

i. fundamental, para crianças de 7 a 12 anos, dividido em primário elementar (4 anos) e primário complementar (1 ano);

ii. supletivo, destinado a adolescentes e adultos.

Pelo mesmo decreto, o ensino normal tinha como objetivo formar professores para o ensino primário através da propagação de conhecimentos e técnicas sobre a educação da infância além de habilitar administradores para estas escolas. $\mathrm{O}$ ensino normal passou a ser articulado com o ensino primário e os primeiros anos do curso secundário e era organizado da seguinte forma:

i. primeiro ciclo (4 anos) para formação de regentes de ensino primário;

ii. segundo ciclo (3 anos) para a formação de professores de ensino primário. (Piletti, pp.87-91)

Com regulamentação anterior a 1946, mas ainda dentro do ensino destinado "às classes menos favorecidas" ( segundo o Decreto-lei № 4 073, de 30 de janeiro de 1943), o ensino técnico-profissional, passa a ter legislação nacional, apoiado também pela criação do SENAI (Serviço Nacional de Aprendizagem Industrial) e o SENAC (Serviço Nacional de Aprendizagem Comercial). Contudo, ele permaneceu em uma posição subalterna em relação ao ensino secundário, já 
que os cursos técnico-profissionais não permitiam o acesso à Universidade, obrigando seus alunos a freqüentarem o curso secundário integral se desejassem continuar seus estudos.

No segundo caso, o ensino secundário mais uma vez sofreu modificações em seus objetivos, explicitando a importância de educar os jovens dessa faixa etária para o futuro:

\begin{abstract}
É que o ensino secundário se destina à preparação das individualidades condutoras, isto é, dos homens que deverão assumir as responsabilidades maiores dentro da sociedade e da Nação (...) um ensino capaz de dar aos adolescentes a compreensão da continuidade histórica da Pátria, a compreensão dos problemas e das necessidades da missão e dos ideais da Nação. (...) Por outro lado, seria de todo impraticável introduzir na educação primária e insinuar no espírito das crianças o difícil problema da significação do homem, este problema crítico, do que depende o rumo de uma cultura e de uma civilização, o rumo das organizações políticas, o rumo da ordem em todos os terrenos da vida social. Tal problema só poderá ser considerado quanto a adolescência estiver adiantada, e é por isso que a formação da consciência humanística, isto é, a formação da compreensão do valor e do destino do homem é finalidade de natureza específica do ensino secundário. (Capanema in Piletti, 2006, p.95-96)
\end{abstract}

Em termos estruturais, os cursos foram subdivididos em ginasial (4 anos) e colegial (3 anos), dividido em dois ramos: clássico ou cientifico, este último mais popular, com praticamente $90 \%$ dos alunos de nível secundário. Com o resgate do Latim e a inclusão de História e Geografia do Brasil, a carga horária de Humanidades voltou a crescer (34,3\%) assim como a de Estudos Sociais $(22,8 \%)$, a área de Matemática e Ciências teve uma redução $(24,3 \%)$, juntamente com outras atividades (18,6\%) (Piletti, pp.87-91).

Os anos que se seguiram ao fim do Estado Novo foram um período fértil de discussões e reivindicações para a sociedade brasileira e a educação também foi testemunha de outra série de mudanças. Aqui cabe ressaltar que a melhor qualidade de discussão democrática no que tange à educação também ocasionou uma lentidão maior na instituição de mudanças. A mais importante destas, a Lei de Diretrizes e Bases da educação nacional, parece exemplificar bem tal fato. Seu projeto de lei chega ao Congresso Nacional em 1948, onde é discutido por 13 anos, antes de ser promulgada em 1961. 
Isso significa que, no período que precede sua promulgação, a educação brasileira manteve a legislação herdada da Constituição de 1946, que já havia reintroduzido princípios suprimidos pela Carta de 1937 (como, por exemplo, a educação como um direito de todos, escola primária obrigatória e gratuita). Em virtude desse fato, esse período de maior democratização viu surgirem diversas campanhas que visavam à ampliação e melhoria do ensino, fosse ele secundário, comercial, para erradicação do analfabetismo, para deficientes ou até mesmo na provisão de material escolar e alimentação aos estudantes (Chagas, p.57). Só para termos um exemplo o número de ginásios públicos no estado de São Paulo aumenta de 41 ( 3 na capital e 38 no interior) em 1940 para 561 (96 na capital e 465 no interior) até 1962. (Beisegel in Fausto, 1984, v.4, p.395).

Outra conquista gradual do período diz respeito à equivalência e integração dos níveis e tipos de ensino: primeiramente foi o ensino técnico a ser equiparado ao nível secundário (1950); depois os cursos técnico, secundário e normal foram equiparados em termos de admissão ao nível superior (1953). Em ambos os casos, a equiparação era obtida através de exames das disciplinas que o candidato não havia cursado, situação que, por fim, foi eliminada com a promulgação da Lei de Diretrizes e Bases (1961).

O tempo necessário para a discussão da Lei de Diretrizes e Bases da educação nacional, se por um lado, permitiu que a educação brasileira permanecesse quase uma década mantendo as mesmas características negativas verificadas ao longo de sua história (como a falta de articulação entre os diversos níveis e sistemas públicos e privados), por outro, acabou resultando em um documento de importância particular, não só para a Nação mas também para este trabalho, uma vez que ele traça objetivos para a educação em todos os seus níveis dentro da sociedade brasileira, objetivos estes que continuam em vigor até hoje, e mesmo na reforma sofrida sob o governo militar (1971), foram mantidos:

a) compreensão dos direitos e deveres da pessoa humana, do cidadão, do Estado, da família e dos demais grupos que compõem a comunidade;

b) o respeito à dignidade e às liberdades fundamentais do homem; 
c) o fortalecimento da unidade nacional e da solidariedade internacional;

d) o desenvolvimento integral da personalidade humana e sua participação na obra do bem comum;

e) o preparo do indivíduo e da sociedade para o domínio dos recursos científicos e tecnológicos que Ihes permitem utilizar as possibilidades e vencer as dificuldades do meio;

f) a preservação e a expansão do patrimônio cultural;

g) a condenação a qualquer tratamento desigual por motivo de convicção filosófica, política ou religiosa, bem como a quaisquer preconceitos de classe ou raça. ( Lei no 4 024/61, Art. 1ํ)

Podemos notar claramente, que, pela primeira vez, surge uma visão do que se deseja para a sociedade brasileira através do sistema de ensino. Nos diversos itens parecemos encontrar a sugestão de que a educação sirva de preparo para o enfrentamento de problemas sociais, tanto atuais como futuros, dentro de uma perspectiva humanística e de desenvolvimento. Em seu aspecto mais estrito, o documento especifica objetivos para cada um dos níveis de ensino, com o primário ficando voltado ao "desenvolvimento do raciocínio e das atividades de expressão da criança, e sua integração no meio físico social", o ensino secundário, ou de grau médio, "destina-se à formação do adolescente (...) em prosseguimento à educação ministrada na escola primária" e, por fim, o ensino superior, que "tem por objetivo a pesquisa, o desenvolvimento das ciências, letras e artes,e a formação de profissionais de nível universitário". (Lei no 4 024/61, Arts. 25, 33, 66)

Como seria de se esperar, a estrutura do ensino também sofreu mudanças que promoveram não só a integração dos diversos sistemas, mas também a articulação dos diferentes níveis (ver Tabela 2). Com a nova lei desaparece também a padronização rígida dos conteúdos curriculares, permitindo-se aos estabelecimentos um grau de variedade, principalmente no caso do $3^{\text {a }}$ série colegial, destinada a preparar alunos para o ingresso nos cursos superiores. A elaboração dos currículos então, passa a ter três diretrizes: 
i. nacional, indicada pelo Conselho Federal de Educação. Disciplinas obrigatórias:Português, História, Geografia, Matemática, Ciências e Educação Física;

ii. regional, indicada pelo Conselho de Educação dos Estados, com outras disciplinas obrigatórias;

iii. local: indicada pelo Conselho de Educação dos Estados, com disciplinas escolhidas pelos estabelecimentos a partir de uma lista. (Piletti, 2006, pp.100-105)

Entretanto, esse processo de mudança e as conquistas obtidas nesse período não tardariam a ser revertidos, com o novo direcionamento político tomado pelo país ao final desse período. Mais uma vez, o aspecto de ruptura na construção da tradição pedagógica brasileira ficaria evidente.

\subsection{O GOLPE MILITAR E OS ÚLTIMOS ANOS DO SÉCULO XX}

O golpe militar que desencadeou a Revolução de 1964 interrompeu o processo de democratização vivido pelo país na década anterior. Ao mesmo tempo em que poucas mudanças estruturais no âmbito da educação puderam ser verificadas no início desse período, as relações entre o Estado militar, escolas, profissionais do ensino e estudantes sofreram mudanças profundas, com uma interferência do primeiro no sentido de regulamentar e coibir a manifestação de estudantes ou a discussão de questões que pudessem comprometer a hegemonia do Estado. (Nosso Século, 1980). As preocupações de natureza política parecem ser predominantes no Decreto-Lei no 467/69, voltado a 
disciplinar e impedir a deflagração de movimentos escolares, organização de passeatas ou distribuição de material subversivo, por exemplo.

Como resultado da Reforma Universitária (Lei no 5540 de 28 de novembro de 1968) o ensino superior viu a organização da universidade em departamentos, a instituição do vestibular classificatório, o crescimento das escolas superiores particulares e, por outro lado, a criação de cursos de pósgraduação ao nível de mestrado e doutorado (Brejon, 1973, pp.67-68). Três anos depois, segue-se nova reforma para o ensino de $1^{\circ}$ e e $2^{\circ}$ graus (Lei no 5692 de 11 de agosto de 1971), onde, aparentemente, também se buscava um desvio do ensino superior através da profissionalização dos cursos de $2^{\circ}$ grau através de um diploma técnico. Ao contrário da Lei de Diretrizes e Bases de 1961, que passou por discussão durante 13 anos, esse novo projeto de lei foi aprovado dentro do prazo de apenas 40 dias exigido pela Constituição de 1969. No âmbito do ensino primário e secundário temos:

i. instituição dos níveis I ( $1^{\underline{a}}$ e 2 séries) e II ( $3^{\underline{a}}$ e $4^{\mathrm{a}}$ séries) dentro do ensino primário em uma tentativa de melhoria do processo de alfabetização além de uma simplificação dos programas ;

ii. unificação dos exames de admissão, fato que fez com que a população do curso ginasial duplicasse em menos de um ano (128 890 em 1967 para 244596 alunos em 1968);

iii. extinção dos ramos profissionais existentes tais como o industrial, comercial, agrícola e normal, através da habilitação de 200 áreas profissionais para a regulamentação do ensino técnico de $2^{0}$ grau em dois níveis: auxiliar técnico ( 3 anos, com o direito de acesso aos exames vestibulares do ensino superior) e técnico (4 anos);

iv. núcleo comum obrigatório de 10 conteúdos específicos dentro de 4 áreas: Comunicação e Expressão; Estudos Sociais; Ciências; Práticas Educativas. (Piletti, 2006, pp. 112-118)

A partir de 1983, nos últimos anos do governo militar, outra Lei liberou os estabelecimentos de ensino da oferta de habilitação profissional. Os objetivos da 
educação nacional permaneciam aqueles mesmos estabelecidos pela Lei de Diretrizes e Bases de 1961, com pequenas mudanças em sua redação, que, por exemplo, estipulava como objetivo do ensino de $1^{\circ}$ e $2^{\circ}$ graus "proporcionar ao educando a formação necessária ao desenvolvimento de suas potencialidades como elemento de auto-realização, preparação para o trabalho e para o exercício constante da cidadania". (Lei № 7 044/82, Art. 1ํ)

Esse processo de "abertura" política verificado na década de 80 parece ter sido o passo inicial da redemocratização da nação, com o advento da anistia política e de eleições diretas de prefeitos e governadores, culminando na primeira eleição presidencial em 1989. No âmbito legislativo, a Assembléia Nacional Constituinte, instalada em 1 - fevereiro de 1987 deu início ao processo de discussão que levaria à nova Constituição, promulgada em 5 de outubro de 1988. Com relação à educação brasileira, aos objetivos atribuídos ao ensino de $1^{\circ}$ e $2^{\circ}$ graus, foram integradas as idéias de educação como dever também da família, e algo que deve ser promovido e incentivado pela sociedade. O artigo 206 lista também uma série de princípios nos quais a educação deve se basear, entre os quais se destacam pelo ineditismo:

i. liberdade de aprender, ensinar, pesquisar e divulgar o pensamento, a arte e o saber;

ii. pluralismo de idéias e concepções pedagógicas;

iii. valorização dos profissionais do ensino;

iv. garantia de padrão de qualidade. (Piletti, pp:135-140)

Tendo por base essas e outras normas constitucionais, iniciou-se o processo de discussão da nova Lei de Diretrizes e Bases da Educação, cuja gestação levou oito anos no Congresso Nacional, sendo a lei finalmente sancionada em 20 de dezembro de 1996, exatamente 35 anos depois da primeira Lei de Diretrizes e Bases. Mais uma vez, o tempo gasto em sua discussão parece ter levado a importantes mudanças:

i. gestão democrática do ensino público de acordo com participação dos profissionais da educação na elaboração do projeto da escola 
e também da comunidade escolar e local em conselhos escolares;

ii. progressivos graus de autonomia pedagógica e administrativa;

iii. nova estrutura escolar: educação básica, Ensino Fundamental e Ensino Médio;

iv. educação superior

v. oportunidades educacionais gratuitas para jovens e adultos que não puderam efetuar seus estudos em idade regular;

vi. educação profissional oferecida em integração com o ensino regular ou educação continuada ou ainda em instituições especializadas e ambientes de trabalho;

vii. educação especial na rede regular para alunos portadores de necessidades especiais.

Ao consolidar e ampliar o dever do poder público para com a educação e, geral, essa lei, apesar de não estabelecer conteúdos curriculares de maneira rígida, pressupunha a formulação de diretrizes que norteassem os currículos e os conteúdos mínimos. Teve início então a elaboração dos Parâmetros Curriculares Nacionais, moldados de forma a oferecer:

(...) uma proposta educacional que tenha em vista a qualidade da formação a ser oferecida a todos os estudantes. O ensino de qualidade que a sociedade demanda atualmente expressa-se aqui como a possibilidade de o sistema educacional vir a propor uma prática educativa adequada às necessidades sociais, políticas, econômicas e culturais da realidade brasileira, que considere os interesses e as motivações dos alunos e garanta as aprendizagens essenciais para a formação de cidadãos autônomos, críticos e participativos, capazes de atuar com competência, dignidade e responsabilidade na sociedade em que vivem. (...)

Para tanto, é necessário que, no processo de ensino e aprendizagem, sejam exploradas: a aprendizagem de metodologias capazes de priorizar a construção de estratégias de verificação e comprovação de hipóteses na construção do conhecimento, a construção de argumentação capaz de controlar os resultados desse processo, o desenvolvimento do espírito crítico capaz de favorecer a criatividade, a compreensão dos limites e alcances lógicos das explicações propostas. Além disso, é necessário ter em conta uma dinâmica de ensino que favoreça não só o 
descobrimento das potencialidades do trabalho individual, mas também, e sobretudo, do trabalho coletivo. Isso implica o estímulo à autonomia do sujeito, desenvolvendo o sentimento de segurança em relação às suas próprias capacidades, interagindo de modo orgânico e integrado num trabalho de equipe e, portanto, sendo capaz de atuar em níveis de interlocução mais complexos e diferenciados. (Parâmetros Curriculares Nacionais, Livro 1, pp.27-28)

Os Parâmetros Curriculares para o Ensino Fundamental foram publicados em 1997, sendo que os Parâmetros Curriculares para o Ensino Médio surgiram em 2000. De particular relevância dentro do objetivo deste estudo estão as seguintes observações presentes no documento referente ao Ensino Médio:

Uma nova concepção curricular para o Ensino Médio, como apontamos anteriormente, deve expressar a contemporaneidade e, considerando a rapidez com que ocorrem as mudanças na área do conhecimento e da produção, ter a ousadia de se mostrar prospectiva. (...)

Mesmo considerando os obstáculos a superar, uma proposta curricular que se pretenda contemporânea deverá incorporar como um dos seus eixos as tendências apontadas para o século XXI (grifo nosso). A crescente presença da ciência e da tecnologia nas atividades produtivas e nas relações sociais, por exemplo, que, como conseqüência, estabelece um ciclo permanente de mudanças, provocando rupturas rápidas, precisa ser considerada. (Parâmetros Curriculares Nacionais, Bases Legais, p.12) 


\begin{tabular}{|c|c|c|c|}
\hline $\begin{array}{c}\text { ESTRUTURA APÓS A AO FINAL DO } \\
\text { GOVERNO VARGAS } \\
(1946)\end{array}$ & $\begin{array}{c}\text { LEI DE DIRETRIZES E BASES DE } \\
1961\end{array}$ & 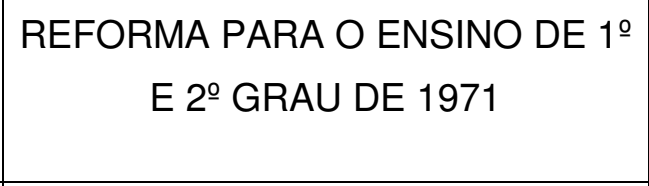 & $\begin{array}{c}\text { NOVA LEI DE DIRETRIZES } \\
\text { E BASES } \\
1996\end{array}$ \\
\hline $\begin{array}{l}\text { 1. Curso ginasial de } 4 \text { anos que agora também } \\
\text { incluía Latim em todos os anos; } \\
\text { 2. Curso colegial de } 3 \text { anos dividido em dois } \\
\text { ramos: } \\
\text { Matérias em comum: } \\
\text { Português, Francês, Inglês, Espanhol, } \\
\text { Matemática, História Geral; História do Brasil, } \\
\text { Geografia Geral e Geografia do Brasil } \\
\text { Curso clássico: } \\
\text { Grego e Latim nos } 3 \text { anos, Filosofia, Física e } \\
\text { Química nos dois últimos e Historia Natural } \\
\text { somente no último, (sem Desenho) } \\
\text { Curso cientifico: } \\
\text { Física e Química nos } 3 \text { anos, } \\
\text { História Natural nos dois últimos, Filosofia } \\
\text { somente no último, incluindo Desenho (sem } \\
\text { Grego ou Latim). }\end{array}$ & $\begin{array}{l}\text { 1- ensino pré-primário, para crianças até } 7 \\
\text { anos; } \\
\text { 2- ensino primário, com } 4 \text { séries anuais } \\
\text { (podendo chegar a 6); } \\
\text { 3-ensino médio: } \\
\text { ciclo ginasial, (4 anos) } \\
\text { ciclo colegial, (3 anos): Modalidades } \\
\text { curso secundário, } \\
\text { curso técnico } \\
\text { curso normal (formação de professores } \\
\text { para o primário e pré-primário); } \\
\text { 4-ensino superior (em universidades ou } \\
\text { faculdades isoladas): níveis de } \\
\text { graduação, pós-graduação e } \\
\text { especialização. }\end{array}$ & $\begin{array}{l}\text { 1-ensino primário de níveis I ( } 1^{a} \text { e } 2 \\
\text { séries) e II ( } 3^{\underline{a}} \text { e } 4^{a} \text { séries); } \\
\text { 2- habilitação de } 200 \text { áreas profissionais } \\
\text { para ensino técnico de } 2^{\circ} \text { grau nível: } \\
\text { auxiliar técnico ( } 3 \text { anos) e técnico ( } 4 \\
\text { anos) } \\
\text { 3- núcleo comum } 10 \text { conteúdos } \\
\text { específicos: Comunicação e Expressão } \\
\text { (Língua Portuguesa); } \\
\text { Estudos Sociais (Geografia, História e } \\
\text { Organização Social e Política do Brasil); } \\
\text { Ciências (Matemática e Ciências } \\
\text { Físicas e Biológicas); } \\
\text { Práticas Educativas (Educação Física, } \\
\text { Educação Artística, Educação Moral e } \\
\text { Cívica e Programas de Saúde). }\end{array}$ & $\begin{array}{l}\text { 1-educação infantil } \\
\text { (pré-escola), } \\
\text { 2- ensino fundamental (antigo } \\
\text { 10 grau) } \\
\text { 3- ensino médio } \\
\text { (antigo } 2^{\circ} \text { grau); }\end{array}$ \\
\hline
\end{tabular}

Tabela 2 Mudanças na Estrutura Curricular do Ensino Brasileiro (2) 


\subsection{O MOMENTO ATUAL E A QUESTÃO DA INOVAÇÃO CURRICULAR}

A alternativa por uma menor rigidez estrutural e de gestão parecia apontar para um período promissor em termos de iniciativas e desenvolvimento da educação no país. Por outro lado, o processo de ruptura constante caracterizado pela 'desconstrução - reconstrução' do sistema, nas indas e vindas administrativas da nação vem deixando uma forte herança : é possível notar, portanto, que diversos problemas já existentes na educação brasileira (entre os quais a alta seletividade, a evasão escolar e a falta de condições mínimas para a implementação de programas, por exemplo) permaneceram. Podemos concluir que as diferentes visões decorridas dos sistemas governamentais que existiram no Brasil acabaram por gerar uma situação onde, apesar da existência de regulamentação, existem marcadas discrepâncias no aproveitamento escolar e na abordagem dos conteúdos a serem transmitidos.

No entanto, as alternativas atuais possíveis de transformação e melhoria do ensino não parecem se encontrar apenas em decretos e leis de caráter vertical. A criação dos PCNs não só estabeleceu uma referência em relação à maneira como os conteúdos devem ser abordados, mas também reforçou a noção de interdisciplinaridade que deve nortear tal abordagem. Como observado no capítulo anterior, uma abordagem relacionada aos estudos do futuro nos parece particularmente adequada a esse processo de prospecção, investigação e aquisição de independência pessoal sugerido no documento dos PCNs do Ensino Médio. Como se caracterizaria esse processo de inovação, portanto? Quais seriam as etapas desse processo?

Para aprofundarmos a discussão cabe aqui diferenciar os termos reforma e inovação curricular. Até o presente momento, discutimos as mudanças efetuadas na educação brasileira sob uma ótica de reformas curriculares. Segundo o Diccionário de las Ciências de la Educación, estas são: 
(...) mudanças profundas na política de um país, que devem ser traçadas independentemente das crises políticas dos governos, devem ter sentido de continuidade e estar enquadradas dentro de uma visão prognóstica sobre o futuro da sociedade a que se referem. As reformas educativas não rompem bruscamente com o lastro cultural ou histórico, mas requerem uma grande dose de inovações, com vistas à melhoria da qualidade de ensino, sua extensão e generalização. Além disto, as reformas hão de ser antecipatórias de necessidades e situações socioeconômicas e culturais, incluindo os aspectos da educação e mercado de trabalho, cuja problemática é cada vez mais aguda. Por tudo isto, uma reforma educativa viável e ética, requer, como condição indispensável, uma ampla participação social da opinião pública e profissional, seja para acomodar a educação ao modelo de sociedade que se elegeu, separa para, através da educação, propiciar um novo modelo de sociedade. (Diccionario de las Ciências de la Educación, 1988, p.1223)

Como podemos perceber, tal definição se aplica claramente às recentes alterações feitas no sistema de ensino brasileiro: elas buscam uma maior continuidade no sistema; não romperam bruscamente com os lastros culturais e históricos de nossa educação; e, como seria de se esperar, buscam uma melhoria na qualidade do ensino além de sua expansão. Também foram resultado de um processo participativo da sociedade em sua gestação e apontam para a educação como ferramenta de adequação à vida em sociedade. De maneira mais genérica, no entanto, elas apenas sugerem uma visão prognóstica de futuro (principalmente na inclusão de idéias relacionadas à rapidez das mudanças ocorridas na sociedade atual), não oferecendo uma visão detalhada desse futuro almejado pela sociedade. Podemos concluir então, que, dentro dessa concepção, a implementação dos estudos do futuro através de uma reforma curricular exigiria um trabalho mais amplo ainda de discussão em sua criação, com a utilização de processos coerentes com os estudos no futuro em sua redação, de forma a incluir claramente não só a visão prognóstica almejada, mas também os conteúdos curriculares a serem trabalhados, assim como os conteúdos curriculares a serem transmitidos aos professores em sua formação para que estes pudessem abordar esse trabalho na escola.

Tal empreitada, apesar de ideal, nos parece ambiciosa demais dentro do panorama educacional brasileiro, o que sugere que uma mudança resultante 
dessa verticalização levaria muito tempo e portanto, não permitiria uma maior relevância aos jovens sendo educados nesse momento. A solução intermediária a essa questão parece estar na implementação de um processo de inovação curricular, ou seja, "a ação permanentemente realizada mediante investigação, para buscar novas soluções aos problemas do âmbito educativo" (Diccionario..., 1988, p.778), "a mudança das práticas existentes através de uma prática nova ou revista" (Bolívar, 2002, p.34). ou "uma idéia, prática ou objeto percebido como novidade pela unidade de adoção pertinente" (Rogers e Agarwala-Rogers, 1976, p.23). Esta seria representada por mudanças mais concretas e menor escala, com uma intervenção mais centrada na prática educativa que no sistema educativo.(Gonzalez e Escudero Muñoz, 1987).

Cabe aqui ressaltar que reformas e inovações não são processos isolados e sim concomitantes. A reforma de um sistema educativo implica em uma reflexão prévia sobre as finalidades da educação, seus objetivos e papel das instituições educativas, enquanto na inovação, os objetivos pretendidos se modificam ou, pelo menos, são questionados. Como conseqüência, a prática da inovação sempre parece ter existido no campo da educação, na medida em que não há desenvolvimento ou progresso sem mudanças e estas não existem sem inovação. Assim, o conceito de inovação parece supor uma visão de futuro em um ambiente modificado. A inovação verdadeira pressupõe sempre novos objetivos emanados de uma investigação com vistas ao futuro, sem desviar a atenção da essência da atividade ligada a um ensino com vistas à solução de problemas. (Hummel,1988)

Dentro de uma perspectiva educacional cabe aqui ressaltar algumas características da inovação educativa, segundo Escudero (in Jorge, 1996, p.86):

i. é um processo de definição, construção e participação social, resultante de deliberação e planejamento, de modo a considerar conteúdos e orientações dos processos educativos;

ii. deve oferecer uma tensão utópica no sistema educativo, que facilita o questionamento, a descoberta, a reflexão e a crítica e, por fim, a modificação; 
iii. um processo mais focado na capacitação e potencialização das pessoas e de instituições do que meramente a implementação de programas ou tecnologias;

iv. não se limita ao estabelecimento de princípios, mas envolve a definição de metas e estratégias metodológicas mais plausíveis aliadas a materiais e recursos.

Através da observação das características expostas acima, nos parece que a implementação de uma abordagem voltada ao estudo do futuro no Ensino Médio brasileiro poderia ser efetuada dentro dessa visão de inovação curricular, uma vez que, tal empreitada poderia ser compreendida dentro da abordagem geral organizadora do currículo para o Ensino Médio proposta pelos PCNs:

i. rever objetivos, conteúdos, formas de encaminhamento das atividades, expectativas de aprendizagem e maneiras de avaliar;

ii. refletir sobre a prática pedagógica, tendo em vista uma coerência com os objetivos propostos;

iii. preparar um planejamento que possa de fato orientar o trabalho em sala de aula;

iv. discutir com a equipe de trabalho as razões que levam os alunos a terem maior ou menor participação nas atividades escolares;

v. identificar, produzir ou solicitar novos materiais que possibilitem contextos mais significativos de aprendizagem;

vi. subsidiar as discussões de temas educacionais com os pais e responsáveis. (Parâmetros Curriculares Nacionais, Livro 1, 2007)

Dessa forma, ela poderia se constituir em uma prática intermediária centrada na prática educativa, e poderia mais facilmente fazer parte do sistema educativo sem requerer inicialmente mudanças de âmbito maior características de uma reforma curricular. Ao contrário de uma reforma curricular, no entanto, o processo não deveria ser 'verticalizado' ou 'coercitivo', mas sim levar em conta as 
diferentes personagens envolvidas no processo, que por fim, determinará o modelo de inovação a ser abordado.

\subsection{AGENTES E MODELOS DE INOVAÇÃO CURRICULAR}

O processo de inovação curricular, como um todo, irá depender inicialmente de diferentes agentes que devem ser considerados: o indivíduo, que adota a mudança, o grupo, como parâmetro fundamental e o quadro institucional e cultural (Huberman, 1973).Tais agentes, por conseqüência, passam a representar as seguintes variáveis: participantes (alunos, professores, diretores, funcionários); estrutura (departamentos, direção geral) e relações (normas, valores, papéis e redes de comunicação informal dentro da escola), com um destaque maior dado à figura do professor:

(...) A necessidade de que a inovação seja adotada e não imposta deve nos fazer considerar a figura e a participação do professor com muito cuidado. Na verdade, muito mais importante que as características pessoais ou o sistema de valores do professor (que influem na adoção da inovação) é a percepção que ele tem dos efeitos desta inovação sobre seus próprios interesses pessoais e as metas da instituição na qual ele trabalha. (Jorge, p.42)

(...) Propor uma mudança na educação escolar implica em reconhecer os educadores como atores-chave nessa mudança, pelo menos enquanto continuarmos pensando em um sistema escolar como um sistema organizado em torno de pessoas (e não de máquinas e tecnologias). Os educadores incorporam o currículo e a pedagogia: suas crenças, saberes, valores, competências e atuação definem mais o que se ensina (e se aprende) na aula do que o currículo prescrito (o currículo documento, o livro escolar). (Torres, 2003)

Dentro dos objetivos propostos por este trabalho, então, a adoção de uma abordagem voltada ao estudo do futuro para estudantes do Ensino Médio passaria obrigatoriamente pela adoção desta abordagem pelos professores, como uma opção de inovação válida para o trabalho que estes realizam. Tal proposta, portanto, deve contemplar as percepções dos professores em relação 
ao objeto de estudo em si, o futuro e aos modos utilizados para efetuar tal estudo.

Teríamos, assim, dois pontos de investigação distintos: como os professores entendem e percebem o papel das questões relacionadas ao futuro e como estes entendem e percebem a viabilidade e utilidade dos modos utilizados para o estudo de tais questões. No primeiro caso, a investigação abordaria de forma mais genérica os valores, conceitos e opiniões destes professores em relação ao futuro, de modo a compor um quadro de atitudes mais ou menos conducentes à adoção desta inovação curricular; no segundo caso, a compreensão e percepção da viabilidade dos estudos do futuro esbarrariam no conhecimento prévio que estes professores possam ter a respeito do assunto em si e iria requerer, conseqüentemente, uma familiarização maior destes professores com as técnicas e conceitos utilizados.

Essa familiarização mostra-se de importância preeminente dentro do conceito de inovação curricular, pois embora a "inovação possa ser feita por vias coercitivas, não será jamais adotada, o que a condena obviamente ao fracasso" (Jorge, pp.46-47). A este fato, Jorge soma a possível resistência do professor (e do ser humano em geral) com relação às mudanças:

Os professores resistem mais que outros profissionais às práticas novas. Seu medo fundamental é o fracasso (...) há um conjunto de forças e pressões para que o professor resista e tema o fracasso: tratam-se das expectativas que sempre circundaram a sua figura, como sendo aquele que deve saber, acompanhada de uma sólida formação intelectual e profissional e um conseqüente status social, que eram, antes, a realidade do professor. (Jorge, p.47).

Isso sugere que, uma vez observado o interesse pela inovação pelos participantes e estabelecida a disponibilidade pela estrutura, a familiarização, portanto, mostra-se essencial para minimizar os conflitos envolvendo as relações dentro da instituição que poderiam advir da adoção da inovação curricular sem maiores preparações nesse sentido. Tal pressuposto indica que o segundo ponto de investigação deste trabalho (a compreensão e percepção da viabilidade dos estudos do futuro no Ensino Médio por parte dos professores) só poderá ocorrer 
a partir do interesse demonstrado pelo conjunto de variáveis $\underline{e}$ após um processo de familiarização dos professores relacionado aos estudos do futuro, já que, de outra forma, ele não se caracterizaria como inovação curricular.

Portanto, a investigação que é objetivo deste trabalho poderá incluir de uma a três fases: uma, fundamental, que é a percepção dos professores do Ensino Médio com relação às questões do futuro; uma segunda, dependente do interesse demonstrado pelas variáveis, que é a percepção e compreensão destes professores com relação à viabilidade e aplicabilidade de técnicas para o estudo do futuro com seus alunos e, por fim, uma final, resultante da continuidade do interesse e disponibilidade das variáveis, que seria a implementação dos estudos do futuro em si, dentro do escopo definido pelas instituições abordadas.

Uma vez transpostas as duas fases iniciais com a demonstração de interesse e disponibilidade para implementação da inovação curricular proposta, teríamos então a questão do modelo de implementação a ser adotado. Huberman (1973) e Morrish (1978) sugerem três tipos principais de modelos de inovação. A adoção destes modelos propostos é baseada na característica comum a estes, que é a descrição do caminho através do qual as mudanças são implementadas, o que nos parece particularmente relevante dentro dos objetivos deste trabalho:

i. investigação e desenvolvimento: passa por quatro fases (investigação, desenvolvimento, difusão e adoção), dentro de um planejamento em larga escala, com divisão de trabalhos e custos iniciais elevados, pressupondo usuários claramente definidos e passivos, que, possivelmente auxiliados por um consultor, acabarão por difundir a inovação ao incorporá-la, em um processo de progressão lógica, claramente demarcado;

ii. interação social: centrado no aspecto da difusão, já que o processo geralmente é iniciado pelo conhecimento da inovação por um indivíduo (mesmo sem a necessidade desta) e o posterior interesse, avaliação, e decisão pela escolha da inovação através da comunicação pessoal com os colegas. A existência ou não de um grupo de "referência" entre estas pessoas pode facilitar ou 
não a adoção da inovação;

iii. solução de problemas: centrado na solução de problemas (propostos pelos usuários ou pelo agente de mudança) baseados nas necessidades ou circunstâncias reais dos adotantes, que desejam a inovação e participam do processo. A ajuda externa tende à orientação e formação, não subestimando as capacidades dos usuários, que por haverem iniciado as mudanças, tendem a adotá-las com maior confiança. ${ }^{13}$

Uma comparação breve entre os três modelos parece sugerir que dos três, o modelo de solução de problemas é o que mais se adaptaria à realidade e necessidade de diferentes estabelecimentos do Ensino Médio e aos objetivos deste estudo, pelas razões que exporemos a seguir.

O modelo de investigação e desenvolvimento, apesar de abrangente, ainda mostra um determinado caráter impositivo em relação aos agentes da mudança (uma vez que estes nem sempre se identificarão com a utilidade das idéias propostas ou participarão do processo de decisões que levaram às novas normas) . Ainda, por sua própria natureza e escala, ele tende a produzir resultados mais de longo prazo, com possíveis custos financeiros para a instituição.

O modelo de interação social, apesar de relevante na sua construção e difusão de redes sociais que poderiam apoiar a inovação, também se mostraria dependente em demasia de um membro "inovador" e "formador de opinião", capaz de não só buscar maiores informações a respeito da inovação em si, como também pela difusão e adoção desta por parte dos outros elementos do grupo. A natureza das relações aqui poderia até mesmo servir como entrave à inovação, já que não existiria garantia da permanência, utilidade ou prejuízo desta pela mera aceitação dos usuários, sem base em necessidades reais.

O modelo de solução de problemas, por fim, ao centrar no usuário as mudanças iniciadas sugeriria uma maior aceitação deste pela inovação, já que

13 O foco da abordagem destes dois autores foi fundamental para a discussão dos modelos e pela escolha de um destes dentro dos objetivos do trabalho. 
esta viria ao encontro de uma necessidade percebida. A figura do agente externo não seria necessariamente impositiva, pois o usuário participaria não só do processo de decisão relacionado à inovação assim como da preparação desta, o que provavelmente aumentaria sua motivação interna e sua participação no sistema como um todo, oferecendo maior solidez à introdução da inovação.

\subsection{CONCLUSÃO}

Verificamos que a educação brasileira sofreu uma série de mudanças em sua estrutura ao longo dos 500 anos de história da nação, mudanças estas nem sempre orientadas para a melhoria ou expansão dos sistemas de ensino. Já a partir dos primeiros anos da colonização, fica mais ou menos evidente a pouca preocupação com os graus de formação básica, sendo que os esforços ao longo dos séculos privilegiaram as formas de acesso ao ensino superior. Por conseguinte, nos parece que uma das principais funções do ensino, que seria a preparação para a vida adulta em sociedade, recebeu pouca atenção explícita nesse sentido nos graus elementares da educação: o ensino médio público "oficializado" surge somente na metade do século XIX e o ensino primário somente é estruturado de maneira a ser integrado com os outros níveis em meados do século XX.

Como parte intrínseca destas mudanças no sistema escolar, temos as diferentes mudanças de caráter administrativo na história do país. A combinação de ambas resultou em um processo de ruptura quase que constante em relação à formação de uma tradição pedagógica brasileira, no sentido de que os sistemas se redimensionam e reinventam após algumas décadas, ao contrário do ensino de outros países como a França, por exemplo. Se, por um lado, tal ruptura sugere uma renovação constante dos processos de ensino, por outro, ela dificulta o desenvolvimento de processos de longo prazo, com diferentes gerações tendo vivenciado diferentes sistemas de ensino e abordagens curriculares. Um dos resultados aparentes é a falta de agilidade e flexibilidade das instituições em 
implementar inovações curriculares concebidas por elas próprias, uma vez que o objetivo geral da educação brasileira (no caso, o acesso ao ensino superior) permanece o mesmo.

Com a criação do mecanismo dos Parâmetros Curriculares Nacionais, ao final do século XX, temos uma visão que busca "informar" a abordagem de conteúdos de modo que as diferentes áreas para a formação do jovem em cidadão operante em seu futuro como adulto, sejam trabalhadas transversalmente, de modo a também prepará-lo para as mudanças vividas por essa sociedade. Tais parâmetros explicitamente sugerem a pesquisa e adoção de "novas alternativas e abordagens pedagógicas". Portanto, uma abordagem mais explicita das questões relacionadas ao futuro parece não só uma abordagem pedagógica viável, mas também pertinente no atual momento.

No entanto, o padrão histórico de lentidão na implementação oficial de reformas assim como de constante ruptura ao longo desse processo, nos parece indicar que essa abordagem teria mais chances de sucesso, caso fosse parte de um processo de inovação curricular, iniciado pelos próprios agentes diretos da educação, coordenadores, professores e alunos, e não necessariamente parte de uma reforma "vertical" e impositiva. 


\section{ENSINANDO O FUTURO: UM PANORAMA DO ESTADO DA ARTE}

\subsection{INTRODUÇÃO}

De maneira geral, este capítulo introduz uma mudança de foco em relação à discussão apresentada até aqui: o que passa a nos interessar não é apenas o estudo do futuro em si, mas sim o ensino do futuro, dentro de um panorama escolar. Assim, este capítulo serve três propósitos principais. Em primeiro lugar, apresenta um breve panorama dos diferentes exemplos de introdução dos estudos do futuro em diferentes níveis educacionais ao redor do mundo, com um foco particular nos programas oferecidos em níveis secundários de educação, correspondentes ao do Ensino Médio brasileiro. Em segundo lugar, ele procura mostrar como a investigação de atitudes dos envolvidos (em particular aquela de professores e alunos) no processo é uma ferramenta fundamental para a implementação bem sucedida de tais programas. Em terceiro lugar, ele dá continuidade à descrição de conceitos e ferramentas iniciada no capítulo anterior, focando a relevância destas dentro dos programas apresentados de modo a facilitar sua escolha.

Dessa forma, a primeira parte do capítulo incluirá uma discussão dos princípios observados na introdução de programas de ensino do futuro em escolas, seguido de exemplos relevantes. Este foco permitirá o surgimento de um modelo conceitual que poderá servir como orientação na adoção de programas semelhantes dentro da educação brasileira, sem que necessariamente estes sejam "cópias" de outros programas adotados. Isso nos parece particularmente importante, uma vez que podem existir características específicas na educação brasileira que requeiram uma adaptação desses programas. A existência de tal pressuposto parte da necessidade, prevista na proposta deste trabalho, de que 0 processo de implementação não se dê de modo "vertical" ou impositivo e sim, 
atenda as necessidades dos alunos e professores envolvidos.

Conseqüentemente, a investigação e posterior discussão das atitudes dos envolvidos no processo merecerão atenção particular, uma vez que não nos parece provável que uma implementação bem sucedida poderá acontecer caso existam barreiras comportamentais de natureza individual ou coletiva que interfiram nessa adoção. Como seria de se esperar, a diversidade de projetos envolvendo a adoção do ensino do futuro em escolas levou a diferentes resultados. No entanto, algumas características parecem ser recorrentes, e estas se referem às questões de natureza psicológica observadas nesse processo, o que, mais uma vez, serviria como referência na adoção de programas voltados ao ensino do futuro dentro da educação brasileira de Ensino Médio. Por outro lado, tais implicações psicológicas do ensino do futuro começaram a ser investigadas só mais recentemente, portanto a discussão apresentada aqui irá se basear nas conclusões obtidas nesses trabalhos, sem pretender uma abordagem mais minuciosa característica de um trabalho primariamente voltado à psicologia.

Finalmente, a descrição de ferramentas e conceitos relacionados ao ensino do futuro mostra-se importante, pois não se trata apenas de escolher entre as diversas ferramentas existentes (e abordadas no primeiro capítulo), mas sim de compreender como essas ferramentas poderiam se mostrar cognitivamente adequadas para o trabalho com os jovens. Dentro desta abordagem, procuraremos mostrar como esta escolha (ou adaptação) das ferramentas poderá facilitar a introdução dos conceitos relacionados ao estudo do futuro de forma a proporcionar não necessariamente uma proficiência dos jovens no uso destas ferramentas, mas sim na adoção de um discurso voltado ao futuro. Tal discurso, seria em si, o objetivo principal a ser buscado através da adoção dessa inovação curricular, o que, acreditamos, por si só, serviria para dar início a processos de mudança de paradigma educacional. 


\subsection{A UNIVERSIDADE E O ENSINO DO FUTURO}

Se toda a educação é para o futuro, então quando e onde deve ser explorado o futuro dentro da educação? (Slaughter in Hicks e Slaughter, 1998, p.44)

Em termos gerais, poderíamos afirmar que muitas das preocupações que deram origem aos estudos do futuro também serviram de inspiração para o surgimento de programas voltados à preparação das novas gerações para enfrentar o futuro. Em uma palestra para a rádio BBC em 1932, o escritor H.G. Wells dava continuidade à suas reivindicações de uma "ciência do futuro" sugerindo, a criação de "faculdades inteiras e departamentos de presciência" que formariam "professores de presciência". (Wells, 1987, pp.89-91).

Apesar do sentido de urgência que ele deu a essas palavras, o decorrer do século XX não presenciou a ampla disseminação de cursos sobre o futuro ou da formação de professores para o trabalho nesta área. Isso talvez tenha se dado, por um lado, pelos paradigmas encontrados na educação tradicional e, por outro, pelo próprio fato dos estudos do futuro vivenciarem um processo de maturação nos meios acadêmicos, o que, naturalmente, fez com que escolas de nível superior em diversos países começassem a oferecer disciplinas específicas voltadas a estes estudos. O primeiro curso foi oferecido em 1966, nos EUA. Diversos outros projetos pilotos foram patrocinados pelo Departamento de Educação e levaram a criação de outros centros onde o futuro era (e continua sendo, como por exemplo, na Universidade de Houston, Clear Lake Campus) estudado e ensinado. No início dos anos 70, logo após o surgimento da World Future Society, sua divisão voltada à educação já contava com milhares de membros trabalhando de maneira direta ou indireta na implementação de programas educacionais voltados ao ensino do futuro. (Slaughter, 2002)

Em sua grande maioria, tais ofertas beneficiaram as disciplinas de foco 
quantitativo, voltadas à análise e extrapolação de tendências, seguidas de outras dedicadas à teoria de sistemas ou estudos de ciclos históricos ou econômicos.

De fato, no nível superior, segundo dados recentes da Acceleration Studies Foundation, um total de mais de 20 programas voltados aos estudos do futuro são oferecidos atualmente no mundo todo ${ }^{14}$. No Brasil, por exemplo, existem hoje quatro núcleos em universidades voltados a este tipo de trabalho : o Laboratório de Estudos do Futuro da Universidade de Brasília (voltado a "aprofundar a discussão e a reflexão acadêmicas, exercitando a expertise prática sobre os desafios nacionais e internacionais") (Laboratório de Estudos... 2007); o Núcleo de Estudos do Futuro da PUC-SP (voltado a "disseminar o pensamento prospectivo através de eventos, pesquisas e diversas outras vertentes do conhecimento") (NEF - PUC-SP, 2007); o Programa de Estudos do Futuro da FIA-USP (voltado a "auxiliar empresas e instituições públicas e privadas, a aprimorar seus processos de planejamento, para que possam prever e lidar com as transformações do seu ambiente de negócios, aproveitando as oportunidades para construir um futuro desejável") (PROFUTURO, 2007); e a Escola do Futuro da Universidade de São Paulo (voltada a "investigar como as novas tecnologias de comunicação podem melhorar o aprendizado em todos os seus níveis") (Escola do Futuro, 2007).

No entanto, assim como Wells, outros estudiosos do futuro sempre parecem ter demonstrado uma preocupação de que este tipo de trabalho fosse oferecido em outros graus de ensino:

Mudanças - constantes, aceleradas, ubíquas - são a característica mais marcante do mundo em que vivemos e nosso sistema educacional ainda não reconheceu tal fato. Propomos, além disso, que as habilidades e atitudes necessárias para lidar adequadamente com mudanças e estas são da mais alta prioridade e não está além nossa engenhosidade criar ambientes escolares que possam auxiliar os jovens a dominar os conceitos necessários para sobreviver em um mundo de rápidas mudanças. (Postman e Weingarter, 1969, pp. xxiii-xiv)

A educação vem fracassando em dar uma resposta adequada à uma

14 Para uma lista completa de países, universidades e programas, consultar http://www.accelerating.org/ Acesso em 16 jun 2007 
sociedade de rápidas mudanças, uma na qual novas idéias, novos temas, novas tecnologias e novos padrões de sociedade exigem novas prioridades e desempenhos daqueles que estão no centro do processo educacional, os professores. A conseqüência deste fracasso está na cisão cada vez maior entre o ambiente da escola e o ambiente dos jovens fora dela. (Farrell, 1972, p. 3)

Antes de abordar o ensino do futuro em outros graus de ensino, surge, contudo, um outro problema, que nos parece ainda não devidamente abordado pelas disciplinas envolvendo estudos do futuro que são oferecidas no nível superior: como formar professores para o trabalho com os estudos do futuro? Dos cursos superiores voltados aos estudos sobre o futuro, nos parece que o mais relevante destes para este trabalho é o curso oferecido por David Hicks na Universidade de Bath, Inglaterra. Tal relevância se explica por dois motivos: é um curso voltado para a formação de professores para o trabalho com o ensino do futuro e vem sendo oferecido de maneira consistente na última década, o que permitiu não só a formação mas também a disseminação dos saberes pertinentes junto às escolas britânicas. Através do trabalho em três áreas principais, pensar sobre o futuro, o futuro na educação e mudar o futuro, o curso aborda não só conceitos relacionados aos modos de estudar o futuro, mas também como as imagens e perspectivas de futuro podem se transformar em elementos essenciais na educação de jovens e crianças $^{15}$.

Tal formação seria, todavia, completamente estranha aos cursos superiores de formação de professores no Brasil? Provavelmente não, e poderíamos também presumir que vários aspectos da formação de professores, tanto no Brasil como no resto do mundo, abordem de maneira implícita a educação voltada ao futuro, uma vez que, segundo Alvin Toffler:

\footnotetext{
15 Os objetivos do curso são : 1.compreender a necessidade de uma perspective de estudo do futuro no currículo; 2.pensar criticamente e criativamente sobre assuntos relacionados ao futuro; 3.desenvolver atividades educacionais que encorajem o pensamento orientado ao futuro. Prospecto do módulo ED2013: Education for the Future Module Handbook 2006-07 Bath Spa University
} 
toda a educação nasce das imagens do futuro, e toda a educação cria imagens do futuro. Assim, toda a educação, quer desejemos ou não, é uma preparação para o futuro. A não ser que nós compreendamos o futuro para o qual estamos nos preparando, podemos causar grandes prejuízos àqueles que ensinamos. (Toffler, 1974, p.3)

Entretanto, ainda que este foco possa existir de maneira indireta em tais programas, tal foco não se mostraria o suficiente em virtude dos paradigmas da educação tradicional. John Saul (1997) sugere que a estrutura escolar tradicional seja permeada por uma ideologia poderosa, de caráter regressivo e corporativista, caracterizada assim:

1. São focadas em si mesmas, e, ao contrário de outros empreendimentos, tem poucas conexões sistêmicas com o mundo maior, ficando assim isoladas de processos de mudança que afetem o sistema global;

2. Têm orientação no passado e no presente, e portanto, pouca capacidade criativa e ou de ação relacionada ao futuro ${ }^{16}$.

3. Funcionam por decreto e resistem à tentativas de mudanças dos imperativos do sistema, isolando lideranças educacionais ou reduzindo inovações no sistema.

Poderíamos concluir que isso por vezes pode até afetar a legitimidade social delas (não seriam estas agentes do bem estar social?) e também as isolar de iniciativas bem vindas que poderiam ser adotadas na transformação da escola como instrumento de formação para as necessidades de um mundo em mudança e dos jovens que habitarão esse mundo no futuro. Isso , no entanto, não parece ter impedido que a educação tradicional tenha se apoderado do discurso "ensino

\footnotetext{
16 Saul aponta este como um dos grandes problemas estruturais da escola que requer correção urgente.
} 
para o futuro" ao longo dos anos e que venha se tornando cada vez mais comum, segundo Gough (1990), seja ele na forma de futuro tácito (onde as questões relativas ao passado e ao presente recém mais atenção, ainda que documentos e projetos sejam sobre o "futuro" na educação), futuro simbólico (onde a menção de conceitos relacionados ao futuro são principalmente retóricos ou parte de um processo de tomada de decisões que, podem ser, na verdade, baseadas em outros aspectos) e futuro inquestionável (onde não existem considerações de outras opções que não aquelas apresentadas pelo desenvolvimento científico e tecnológico).

Conseqüentemente, a apropriação do termo "futuro" na educação não significa que abordagens específicas relacionadas a esses estudos sejam, de fato, implementadas na prática, mesmo em países onde o termo "futuro" em si é parte explícita dos documentos oficiais relacionadas a mudanças ou projetos em educação, quer eles envolvam questões pertinentes ao futuro como sustentabilidade, cidadania e desenvolvimento ou não. $O$ que podemos certamente notar é que, apesar da semelhança entre projetos nacionais e estrangeiros voltados à educação para cidadania ou desenvolvimento sustentável, por exemplo, esta pesquisa não encontrou, até o presente momento, evidências de uma abordagem explícita dos estudos do futuro, voltada à educação em cursos superiores de formação de professores no Brasil, pelo simples fato de que tal abordagem não parece fazer parte da tradição pedagógica brasileira. O resultado aparente disso é que existem poucas propostas (Litto, 1997) e ainda menos evidências de uma abordagem explícita relacionada aos estudos do futuro nas escolas brasileiras de ensino fundamental e médio. Mais, pouco se sabe sobre o que tais professores "pensam sobre o futuro", o que nos sugere que responder à indagação: qual futuro? deveria, na verdade, preceder a indagação como pensar o futuro?

De acordo com as indagações acima, então, um determinado grau de formação de professores para esse tipo de trabalho com o ensino do futuro, naturalmente, não deveria ser negligenciado, mas seria preciso lembrar que, 
mesmo assim, não bastaria apenas uma familiarização dos professores com técnicas e abordagens a serem utilizadas, mas sim também investigar a própria visão dos professores em relação ao futuro, como sugeriu Toffler. Hicks afirma que um elemento não pode ser dissociado do outro, tornando a tarefa de identificar as atitudes e visões dos educadores um objetivo de importância fundamental na implementação de um programa deste tipo:

(...) imagens do futuro têm claramente um papel crucial na mudança social e cultural. Minhas próprias ações do presente, por exemplo, são influenciadas pelas imagens que eu tenho de meu "eus" passados e futuros. Se me sinto equilibrado, reconhecido e competente no meu presente, é porque esta imagem de mim mesmo foi refletida por amigos e colegas no passado. Dessa forma, projeto adiante uma imagem pessoal em meus compromissos pessoais e profissionais futuros. Existe um elemento de profecia auto-realizável aqui, que todos nós vivenciamos em relação à expectativas de nossos professores durante nossa educação. (Hicks, 2002, p.79)

Ao levarmos em conta os pontos anteriormente mencionados, que envolvem o sistema educacional como um todo, torna-se relativamente simples compreender a razão pela qual a questão da implementação do "futuro" na educação ainda não parece ter encontrado uma solução mais simples. No entanto, um dos principais expoentes atuais das questões do futuro na educação, Richard Slaughter, aponta para uma perspectiva ideal que, se ainda ambiciosa, pode indicar áreas de atuação e investigação que levem a resultados mais amplos a longo prazo. Dessa forma, a perspectiva ideal para a inclusão dos estudos do futuro na educação incluiria:

- a introdução de conceitos relacionados aos estudos do futuro por todo o currículo;

- a integração de abordagens relacionadas aos estudos do futuro no treinamento de professores e em cursos de desenvolvimento desses profissionais.

- relacionar estruturas curriculares à questões mais amplas e de longo prazo; 
- o uso de abordagens dos estudos do futuro no planejamento estratégico de escolas e de sistemas escolares;

- a revisão do conceito de liderança educacional de forma a incluir um elemento pró- ativo. (Slaughter, 1994, p.50)

Naturalmente, o escopo deste trabalho não poderia incluir cada um dos elementos presentes em tal perspectiva, uma vez que algumas dessas áreas, por sua natureza sistêmica, estejam além do porte de uma intervenção como a desta pesquisa. Contudo, este trabalho buscará combinar elementos dessa perspectiva com as condições já existentes no Ensino Médio brasileiro, de forma a investigar a viabilidade de tal implementação, de dentro para fora do sistema, como parte de um processo de inovação curricular, discutido no capítulo anterior.

\subsection{ENSINANDO O FUTURO PARA CRIANÇAS E JOVENS:}

\section{POR QUÊ?}

O ensino do futuro para crianças e jovens nos parece particularmente relevante, uma vez que tais crianças e jovens serão os verdadeiros "usuários" do futuro. E, de fato, experiências voltadas ao ensino do futuro não são um fenômeno novo em educação, ainda que diversos projetos nesse sentido não sejam bem documentados ou, com maior freqüência, não tenham continuidade a despeito do entusiasmo inicial.

$\mathrm{Na}$ verdade, no caso em particular da educação em escolas, tais empreitadas freqüentemente enfrentam uma série de obstáculos: em primeiro lugar, podemos mencionar a questão da formação dos professores para tal tarefa, como já mencionado anteriormente; em segundo, a diversidade de abordagens possíveis para tal tarefa multiplica o número de ferramentas, dificultando a criação de um "livro-texto", por exemplo; em terceiro lugar, a 
persistência dos paradigmas educacionais vigentes, que resultam em indagações do tipo "como ensinar algo que não existe?"ou "como encontrar espaço para isso em meio a programas por demais densos em conteúdos?"; por fim, a questão, também já levantada, que relaciona as visões de futuro dos professores às iniciativas nesse sentido. Como se tais obstáculos não fossem o bastante, alguns futuristas (Evenson, 2004) chegam até mesmo a sugerir que o desenvolvimento das habilidades relacionadas aos estudos do futuro requer, além de uma educação diversificada, um certo grau de experiência de vida, já esta que serviria como referencial para o teste de hipóteses e teorias relacionadas ao futuro. Como conseqüência, boa parte da cultura adolescente (e quase a totalidade da cultura infantil), focada em questões individuais e imediatistas, não propiciaria a habilidade de visualizar esses futuros ou ainda realizar perguntas relevantes sobre qual o caminho que leva a eles.

Entretanto, tais obstáculos aparentes não impediram a realização de projetos bem sucedidos nesse sentido: o programa criado e conduzido por Paul Torrence até sua morte, Future Problem Solving (FPS, 2007), por exemplo, é mantido até hoje, envolvendo anualmente mais de 250.000 estudantes da Austrália, Canadá, China (Hong Kong), Coréia, Malásia, Nova Zelândia e Rússia; o projeto de estudos do futuro on-line Images of the Future Project, conduzido por Cole Jackson (in Gidley e Inayatullah, eds, 2002) na Flórida atrai e envolve alunos de diferentes escolas nos EUA, o trabalho de Simon Nicholson e Ray Lorenzo (1980) na escola do futuro Montclair (Nova Jérsei, EUA) e o de David Hicks e Cathie Holden na Grã- Bretanha (1995) e Jane Page na Malásia (2000) apontam para a importância de tais abordagens na revisão de conteúdos e desenho de currículos de educação crianças e jovens. Na Austrália, algumas escolas da região de Queensland adotaram um projeto piloto para um programa de quatro semestres e vinte cinco módulos voltados aos estudos do futuro em nível secundário, com resultados encorajadores. (Board of Senior Secondary School Studies, 1999).

Suas cinco diretrizes curriculares incluíram: 
- uma exploração de realidades globais;

- a compreensão do desenvolvimento sustentável;

- uma perspectiva de estudos do futuro no currículo;

- a re-orientação da educação para um futuro sustentável;

- aceitar o desafio. (Fien, 2002)

De uma forma geral, outros programas tiveram diretrizes semelhantes, com as devidas adaptações em relação às capacidades cognitivas das diferentes faixas etárias onde foram aplicados. Podemos dizer que tais programas tiveram como objetivo:

- capacitar estudantes a entender os elos entre suas próprias vidas no presente e aquelas de outras pessoas no passado e no futuro;

- aumentar a compreensão das influências culturais, políticas, sociais e econômicas que moldam as percepções de futuro pessoais, locais e globais;

- desenvolver habilidades, atitudes e valores que encorajam a previdência e capacitam estudantes a identificar tanto futuros prováveis como desejáveis;

- trabalhar para alcançar um futuro mais justo e sustentável no qual tanto o bem estar das pessoas, como o do planeta, sejam de igual importância. (Hicks, 2001)

Uma das razões possíveis para explicar o sucesso de tais iniciativas seja porque talvez, e mais do que qualquer outra faixa etária, crianças e jovens parecem ter interesse profundo em tais questões ${ }^{17}$. Sua curiosidade natural e a observação do mundo "adulto" à suas voltas muitas vezes encorajam um certo grau de questionamento não só a respeito de seus futuros pessoais, mas

17 Freqüentemente, pesquisas mostram que é a falta de perspectivas em relação ao futuro que termina por criar desinteresse no assunto por parte de jovens e crianças. 
também da forma como viverão seus futuros em sociedade. Poderíamos portanto afirmar que, nessa fase, eles vivem um período onde a educação pode transformar sua visão de mundo. À medida que crescem, freqüentemente esse entusiasmo pode acabar sendo substituído por conformismo, cinismo e desesperança, já que, muitas vezes, o processo educacional não oferece chances ou viabiliza as ferramentas necessárias para o pensar e agir no futuro fazendo com que muitos deles percam o interesse no assunto:

\begin{abstract}
É pouco surpreendente que muitos jovens fujam de realidades pouco confortáveis através de um amplo uso de estratégias pelas quais eles as evitam. Estas incluem: o esporte, a TV, vídeo, drogas e uma cada vez mais rápida e freqüentemente antagônica cultura popular (....) Com o rápido desenvolvimento e jogos de computador e com o nascer das realidades virtuais, a tela tecnológica entre os jovens e o mundo se torna mais opaca, mais difícil de penetrar, entender ou controlar (...) podia-se esperar que educadores lidassem efetivamente com esse prognóstico sombrio e, até certo ponto, muitos tentaram. mas estes têm de enfrentar um sistema de imperativos poderoso que continua a trabalhar numa direção diferente (...) e eles pouco podem fazer para subverter as premissas básicas dessa estrutura, de sistemas educacionais guiados pelo passado, focados no presente de curto prazo e indiferentes ao futuro. Tal posição seria apropriada para períodos de estabilidade. As soluções do passado permanecem válidas para o presente. As estruturas do passado são adequadas às necessidades do presente. Mas em períodos de instabilidade, onde existem grandes riscos, o pensamento de curto prazo é decerto perigoso. (Slaughter, 1995, pp 117-118)
\end{abstract}

Dessa forma, não é surpreendente que uma boa parte das pesquisas iniciais sobre "ensino do futuro" voltou-se à, ou ao menos incluiu, uma exploração das visões dos jovens em relação ao futuro. Tanto pesquisas australianas das décadas de 80 e 90, como pesquisas européias e americanas no período pareciam apontar um grau de negatividade e desesperança em questões relativas ao meio ambiente, à economia, desemprego e saúde (Hicks, 2000). Outro estudo americano (Johnson, 1987) envolvendo 600.000 crianças em fase escolar encontrou resultados semelhantes no que tange às questões globais, contrastando com um visão menos negativa de futuro local ou nacional e uma visão otimista e um tanto conservadora de futuro pessoal. 
Apesar de resultados semelhantes também terem sido obtidos em uma pesquisa mais recente, realizada em 2005 (Mack, 2005), com crianças de escolas primárias australianas, o relatório final sugere que visões negativas sejam resultado também da influência da mídia e da ficção cientifica às quais as crianças estão expostas e não necessariamente da imaginação infantil, e sim do imaginário coletivo produzido pelos adultos e transmitido pela mídia. Tais conclusões parecem corroborar as de relatórios anteriores, que sugeriam que os jovens também encontravam dificuldades em imaginar 'futuros desejáveis' de modo tão fluente como conseguiam expressar seus medos e temores em relação ao futuro.

Os resultados de outra pesquisa realizada na Grã- Bretanha com 400 jovens com idades variando entre sete e dezoito anos em oito escolas diferentes (quatro primárias e quatro secundárias), servem também para ilustrar como essa "perda de inocência" se acentua em maior grau ao final da adolescência:

i Crianças com 7 anos de idade: mais otimistas na crença de que a vida será melhor para todos; ambivalentes em relação à diminuição da pobreza e poluição;

ii Crianças com 11 anos de idade: maior compromisso com questões globais e a melhoria do meio. Ainda crêem que a vida será melhor, mas de forma menos intensa que as crianças mais jovens, possuem por vezes uma crença quase ingênua na melhoria do planeta e querem fazer parte disso;

iii Jovens com 14 anos de idade: menos otimistas que o grupo anterior em relação à melhoria de condições e ambivalentes em relação a seu papel no processo;

iv Jovens com 18 anos de idade: menos positivos em relação à mudanças locais ou globais. Oferecem exemplos de ações de mudança por eles efetuadas, mas são céticos da influência destas. 
Percebem um "sistema" que influencia as pessoas, mas não se vêem como parte dele. (Hicks e Holden, 1995)

Em outras pesquisas semelhantes realizadas em países não ocidentais (Gildey e Inayatullah, 2002), a visão de um "sistema" do qual os jovens não fazem parte permanece, ainda que tingida de características especificas de suas culturas (por exemplo, no questionamento dos sistemas políticos ou de dogmas religiosos no caso do Paquistão, Singapura e Tailândia).

Os projetos e pesquisas acima sem dúvida apontam para a necessidade, que nos parece cada vez mais urgente, de que o trabalho dos professores ofereça aos jovens a possibilidade de criar aquilo que Slaughter denominou "discurso futuro" (1995, pp.65), ou seja, a habilidade através da qual seu pensamento sobre o futuro (e porventura, suas ações nesse sentido), sejam articulados. Essa urgência também encontra eco nas idéias do ensaísta Peter Garret, ex-líder da banda australiana Midnight Oil e recém-empossado Ministro do Meio Ambiente na eleição australiana de 2007:

Todo $o$ ato de ensinar e aprender ocorre primariamente para se atingir determinados fins no futuro: pessoais, profissionais e sociais. Toda a empreitada educacional é concebida para contribuir para o maior desenvolvimento da sociedade como um todo. Estes são verdadeiros interesses futuros. (Slaughter in Hicks e Slaughter, eds. p.58)

A tarefa para o professor nesse momento é a mesma que sempre foi, só que agora ela parece mais urgente, mais importante. Parecemos viver dias de ondas turbulentas e todos os problemas que nos maltratam e nos ameaçam foram compreendidos, mas não parecemos ser capazes de resolvê-los. Então a tarefa de nos ajudar a entender um pouco mais sobre nós mesmos é crítica. Precisamos vislumbrar como chegamos ao nosso estado atual. Precisamos mergulhar nas grandes perguntas sobre a natureza dos seres humanos e sua condição. E, mais importante, precisamos explorar o tipo de senso comum que podemos buscar juntos para cultivar e manter a criação. (...)

A geração "fast-forward" está sendo moldada por estímulos audiovisuais, não pela literatura. "Fast-forward" não significa apenas mover-se para frente com rapidez, mas também ignorar coisas que são complexas, deprimentes ou enfadonhas demais... Não proponho nada de novo, mas 
simplesmente que os professores exponham os mitos do progresso e prosperidade que mantém esse castelo de cartas de pé. Eles devem colocar em foco uma visão que não lide superficialmente com o pesadelo, mas que consiga criar entusiasmo em relação ao potencial do espírito humano, apesar das circunstancias terríveis. Nesse momento os jovens, em especial, não têm fé no futuro e portanto não se mostram interessados em lidar com o presente a não ser para torná-lo o mais tolerável possível. Precisamos de professores que nos lembrem de nosso potencial de exercício da razão, das escolhas e dos sacrifícios, mas, acima de tudo, do potencial para participar nessa grande luta de esperança, renovação e de um lar comum. (Garrett in Headon, 1990, p. 42)

\subsection{ENSINANDO O FUTURO PARA CRIANÇAS E JOVENS: COMO?}

Ao analisar os objetivos propostos em diferentes programas, o trabalho de Slaughter também apontou para os diferentes níveis de implementação dos estudos do futuro na educação:

-Na pré-escola : ênfase em treinamento de professores de desenvolvimento de currículos voltados à continuidade de uma abordagem do futuro desde os primeiros anos;

-Na escola primária: uma perspectiva no treinamento de professores e desenho curricular envolvendo conceitos, exercícios e ferramentas simples;

-No ensino secundário: uma perspectiva dos estudos do futuro como assunto e disciplina, discurso, métodos e aplicações sociais voltadas ao futuro

-No ensino superior: discurso avançado, pesquisa, estudo sobre a disciplina e implementação social. (Slaughter, 1994, p.50)

Naturalmente, qualquer pesquisa nestes níveis dentro do panorama da educação brasileira seria certamente relevante, dada a escassez de trabalhos nesse sentido. Contudo, já existem programas de nível superior voltados aos 
estudos do futuro no Brasil (um exemplo é o curso de Análise e Previsão Tecnólogica oferecido pela Faculdade de Economia e Administração da Universidade de São Paulo), onde se encontram os objetivos propostos por Slaughter. O trabalho com o ensino fundamental (que, no caso brasileiro, envolve tanto a pré-escola como a escola primária), por sua vez, encontra algumas limitações: no caso da pré-escola, as pesquisas existentes ainda nos parecem incipientes, mesmo fora do país e, no caso da escola primária, apesar do uso de ferramentas e conceitos simples parecer promissor, os objetivo propostos para ambos os níveis, que envolvem o desenvolvimento de currículos, estaria além dos limites dessa pesquisa (pois ela trata da inclusão dos estudos do futuro como uma ferramenta para inovação curricular sem alterar os conteúdos deste).

As razões que levaram esta pesquisa a optar pelas escolas de Ensino Médio (correspondente ao nível secundário descrito acima) estão ligadas em primeiro lugar, à maior capacitação e maturidade dos alunos deste nível para este tipo de trabalho; em segundo lugar, pela observação de que as visões dos jovens tendem a ser mais negativas em relação ao futuro justamente no período de suas vidas que antecede o ingresso na "vida adulta"; em terceiro lugar, pela maior flexibilidade de ferramentas e abordagens à disposição dessa faixa etária para este tipo de trabalho e, finalmente, por uma possível maior especialização dos professores desse nível no ensino brasileiro.

Também, como já mencionado anteriormente, diversos programas foram desenvolvidos e testados nos últimos anos nesse nível de ensino, existindo relatórios sobre a eficácia e relevância de tais programas (Didsbury in Hicks e Slaughter, 1998). Todavia, ao invés de descrevermos minuciosamente a estrutura destes, procuraremos optar por uma síntese de propósitos, abordagens e ferramentas. A partir dos objetivos, necessidades e interesses observados em cada situação específica nas escolas pesquisadas, seriam então escolhidas tais ferramentas e abordagens.

Tal decisão se justifica por duas razões: pelo fato de que, em virtude das características da educação brasileira (abordadas no capítulo 3) nos parece ideal 
a busca de soluções dentro do nosso sistema e a partir dos objetivos educacionais gerais por ele descritos. Acreditamos que isso poderia oferecer resultados em maior consonância com as necessidades de professores e alunos brasileiros e, assim, facilitar a disseminação desses programas, por exemplo. Por outro lado, não acreditamos ser ideal uma simples replicação de programas e conteúdos (apesar das abordagens e ferramentas a ser propostas serem flexíveis o bastante para atingir diferentes objetivos) devido às diferenças estruturais e culturais existentes nos sistemas escolares de diferentes países.

De fato, essa flexibilidade na abordagem não parece ser relevante somente no sentido de adaptar os objetivos às características da educação brasileira, mas também no sentido de fornecer flexibilidade no uso de ferramentas de modo a criar o 'discurso futuro' mencionado por Slaughter. Daí a importância do uso de diferentes metodologias, para que tal discurso possa englobar não só as imagens de futuro negativas dos jovens assim como capacitálos para criar imagens de futuro desejáveis e ainda, segundo ligar tais imagens do mundo a projetos voltados à ação. (Boulding, 1990, p.29)

Para tanto, utilizaremos como referência (ver Tabela 3) a tipologia sobre estudos do futuro encontrada no trabalho de Jennifer Gidley (2004), cujo objetivo era mapear diferentes abordagens, descrevendo a natureza do trabalho, os tipos de estudos do futuro associados a estas abordagens, os paradigmas encontrados típicos de cada tipo de estudo, seguido das ferramentas e dos objetivos educacionais para cada uma das abordagens. Tal tipologia nos parece particularmente relevante pois ela aborda diferentes dimensões dos estudos do futuro:

a- abordagem genérica:

Nesta categoria, o futuro é tratado sob a perspectiva de provável, possível, desejável e prospectivo. Estas "orientações" para o ensino do futuro aos jovens, sugeridas por Gaultung e Bjerstedt (in Gidley, 2004), permitem que o trabalho leve à preparação dos jovens para a ação, reduzindo a prevalência da idéia de 
"um futuro" e possibilitando a exploração de "futuros alternativos".

b- descrição:

Nesta categoria, são descritas as perspectivas do trabalho, sejam estas a análise global, o uso da imaginação, a discussão de valores ideológicos ou o fortalecimento da auto-confiança para ação.

c- estudos do futuro associados:

Nesta categoria, encontramos referência às diferentes abordagens encontradas ao longo do desenvolvimento dos estudos do futuro como disciplina, na maneira como estas atendiam as necessidades/ visões de futuro (como por exemplo, a descrição de uma tendência como evidência de "um futuro" ou a interpretação cultural para a criação de utopias ou "vários futuros").

d- paradigmas:

Nesta categoria, encontram-se os diferentes paradigmas educacionais que sustentam as diferentes orientações para este trabalho (como por exemplo, empírico, construtivista e ativista), o que facilitaria a escolha de um tipo de orientação por determinado professor/escola baseado ou no trabalho que é normalmente desenvolvido pelos alunos ou no trabalho que poderia complementar o trabalho que é desenvolvido.

e- métodos de pesquisa;

Nesta categoria encontram-se as ferramentas típicas utilizadas por futuristas para o tipo de trabalho sugerido nas categorias anteriores, tais como a análise de tendências de forma quantitativa, a construção de cenários baseados em visões, a analise textual, chegando até o planejamento de ações, sob uma orientação prospectiva.

f- objetivos

Por fim, esta categoria descreve os objetivos genéricos das diferentes abordagens, estabelecendo assim os diferentes tipos de 'discurso futuro' a serem exibidos pelos estudantes, tais como a extrapolação, a noção de possibilidades 
alternativas, a consciência crítica e sua capacidade de mudança. 
Tipologia dos Estudos do Futuro

\begin{tabular}{|c|c|c|c|c|}
\hline $\begin{array}{l}\text { Abordagem } \\
\text { Genérica }\end{array}$ & PROVÁVEL & POSSÍVEL & DESEJÁVEL & PROSPECTIVO \\
\hline DESCRIÇÃO & $\begin{array}{l}\text { Análise de tendência - } \\
\text { global, ecológica }\end{array}$ & $\begin{array}{l}\text { Imaginação, idéias } \\
\text { criativas, flexibilidade }\end{array}$ & $\begin{array}{l}\text { Valores } \\
\text { crítico } \\
\text { ideológico }\end{array}$ & $\begin{array}{l}\text { Ação } \\
\text { autoconfiança } \\
\text { fortalecimento }\end{array}$ \\
\hline $\begin{array}{l}\text { ESTUDOS DO } \\
\text { FUTURO } \\
\text { ASSOCIADOS }\end{array}$ & $\begin{array}{l}\text { Previsão, } \\
\text { Quantitativo } \\
\text { A tendência é o destino } \\
\text { ("um" futuro) }\end{array}$ & $\begin{array}{l}\text { Culturais } \\
\text { Interpretação, } \\
\text { utopias } \\
\text { (vários futuros) }\end{array}$ & $\begin{array}{l}\text { Crítico } \\
\text { Pós-moderno } \\
\text { ideológico } \\
\text { ("outro" futuro) }\end{array}$ & $\begin{array}{l}\text { Integração } \\
\text { Transformação } \\
\text { Fortalecimento } \\
\text { (“Futurizar") }\end{array}$ \\
\hline PARADIGMAS & $\begin{array}{l}\text { Positivista, empírico, } \\
\text { analítico }\end{array}$ & $\begin{array}{l}\text { Construtivista, } \\
\text { interpretativo, } \\
\text { hermenêutico }\end{array}$ & $\begin{array}{l}\text { Crítico } \\
\text { emancipação }\end{array}$ & $\begin{array}{l}\text { Mudança de paradigma } \\
\text { transformacional, } \\
\text { ativista }\end{array}$ \\
\hline $\begin{array}{l}\text { MÉTODOS DE } \\
\text { PESQUISA }\end{array}$ & $\begin{array}{l}\text { Quantitativos } \\
\text { previsão } \\
\text { pesquisas } \\
\text { cenários de tendências }\end{array}$ & $\begin{array}{l}\text { Qualitativo, } \\
\text { diálogo } \\
\text { colaborativo } \\
\text { visões criativas }\end{array}$ & $\begin{array}{l}\text { Analise textual, } \\
\text { analise de mídias, } \\
\text { artefatos culturais } \\
\text { projeção }\end{array}$ & $\begin{array}{l}\text { Integral } \\
\text { Projeção } \\
\text { planejamento de ação } \\
\text { pesquisa }\end{array}$ \\
\hline OBJETIVO & $\begin{array}{l}\text { Generalização, } \\
\text { extrapolação }\end{array}$ & $\begin{array}{l}\text { Abertura } \\
\text { possibilidades } \\
\text { alternativas }\end{array}$ & $\begin{array}{l}\text { Consciência crítica, } \\
\text { desconstrução }\end{array}$ & $\begin{array}{l}\text { Fortalecimento, } \\
\text { mudança } \\
\text { transformação }\end{array}$ \\
\hline
\end{tabular}

Tabela 3 - Quadro com a organização dos diferentes tipos de estudos do futuro sugerido por Gidley 


\subsection{ENSINANDO O FUTURO PARA JOVENS: FERRAMENTAS}

A tipologia proposta por Gidley revela-se funcional, uma vez conhecidos os objetivos do trabalho com o ensino do futuro a ser realizado. Para a implementação de tal trabalho resta ainda, então, descrever de que modo as ferramentas discutidas no capítulo 1 podem ser adaptadas para o trabalho com jovens e como o trabalho pode ser estruturado.

No caso das ferramentas em si, existe certamente a probabilidade de que os próprios professores não estejam familiarizados com o uso destas. Sugerimos, assim, a adaptação, da proposta dos diferentes autores (Kauffman, 1976; Inayatullah, 2005; Schultz 2005), dos princípios gerais encontrados nestas ferramentas, que visa a possibilitar o uso inicial destas por parte de professores e alunos além de permitir um posterior aprofundamento:

a- "Linhas do tempo": talvez a mais simples de todas as ferramentas para ajudar jovens a "visualizar" o futuro e discutir sua compreensão do tempo e de suas implicações em termos pessoais, locais e globais;

b- "Teias" ou "Redes" do futuro: também conhecidos como "mapas mentais" são instrumentos de visualização das conseqüências diretas e indiretas de uma mudança ou desenvolvimento em particular ${ }^{18}$

c- Visões e Crenças sobre o futuro: uma das ferramentas mais comuns, através, por exemplo, do uso de questionários ou da escolha de imagens ou "metáforas" sobre o futuro, ela permite a detecção de atitudes e a articulação de causas e efeitos em relação ao futuro;

d- Grupos de opinião: o trabalho com esta ferramenta (normalmente simbolizado pelo uso da técnica Delphi que, naturalmente, requer cuidadosa elaboração e análise) pode ser adaptado às necessidades de grupos de alunos, que podem assumir o papel de peritos ou comissões (ou até mesmo consultar outros grupos de peritos, sejam eles outros alunos mais velhos, pais, professores, profissionais, por

18 O conceito foi desenvolvido em 1971 por Jerome C. Glenn, diretor do Millenium Project e consultor da RAND Corporation. 
exemplo) para avaliar, combinar, ou então re-orientar diferentes visões de futuro ou planos de ação;

e- Construção de cenários: em termos simples, a produção de previsões ficcionais alternativas para uma determinada situação, em algum ponto do futuro. Tais previsões devem levar em consideração uma série de condições alternativas que levaram a tais cenários. A construção de cenários alternativos parece ser uma das ferramentas mais poderosas no trabalho com jovens, dissipando a visão de "um futuro"; (Slaughter, 1995, p. 17)

f- "História improvável" "história do futuro", narrativas incompletas: ferramentas extremamente flexíveis e de fácil implementação, esse tipo de narrativa pede que os participantes descrevam, no primeiro caso, como o futuro teria sido diferente caso determinado fato ocorresse de modo distinto (por exemplo, imaginar a questão do terrorismo nos dias de hoje sem os atentados de 11 de setembro); no segundo caso, como os fatos presentes levaram a um determinado futuro (que pode ser proposto pelos próprios participantes) ou, no último, como a compreensão dos fatos presentes leva a determinado futuro. Em todos os casos (assim como no uso de cenários) o que se desenvolve aqui é a habilidade de ligar processos em diferentes momentos do tempo e elementos de ação na mudança desses eventos;

g- "Comunidades", "ficção cientifica": outros exemplos de ferramentas voltadas ao desenvolvimento da imaginação, o uso de "comunidades" (facilitado hoje por ambientes virtuais) permite o uso da imaginação aliada à experimentação e observação de resultados (possibilitando ainda, o desenvolvimento de noções relacionadas à sistemas, por exemplo). O uso da "ficção científica", através da exposição a livros, filmes que "representem" algum tipo de futuro, permite também que os participantes identifiquem qual a orientação (provável, desejável, possivel.) desses futuros e analisem criticamente as características destes, despertando a consciência crítica e sugerindo planos de ação para atingir ou evitar tais futuros 
h- Análise de tendências/ ciclos de mudança: talvez a ferramenta mais compatível ao trabalho realizado em ciências exatas (equações matemáticas, gráficos, funções, por exemplo), ela permite compreender e visualizar questões pertinentes ao futuro (crescimento populacional, distribuição de alimentos, taxas de desemprego) baseado em noções de crescimento exponencial ou porcentagens, por exemplo, aliando esses dados a uma série de perguntas (ver Tabela 10) que podem explicar como a tendência se comporta;

i- teoria de sistemas: apesar da amplitude e complexidade do assunto, seria desejável despertar uma maior consciência nos jovens em relação à analise ou descrição de como um elementos de um sistema funcionam em conjunto para produzir determinado resultado, familiarizando-os com noções relacionadas à feedback positivo e negativo de sistemas, canais e casualidade, por exemplo, através de experiências simples em sala de aula.

A estrutura do trabalho, por outro lado, não parece diferir muito dos processos habituais de investigação e pesquisa (o que, mais uma vez, assemelha epistemologicamente o trabalho com os estudos do futuro do trabalho com outras disciplinas em ciências sociais, por exemplo). As duas estruturas propostas a seguir abordam o trabalho tanto em um sentido mais crítico (porque amplo e extenso), como em um sentido mais genérico e flexível, através das seguintes etapas:

Modelo de trabalho proposto por Schultz (in Inayatullah e Wildman, 1998)

i. Identificar e monitorar mudanças através da análise de questões emergentes (o que ele chama de "observação ambiental")

ii. Analisar criticamente o impacto de tais mudanças; 
iii. Imaginar futuros alternativos;

iv. Criar visões de futuros desejáveis;

v. Planejar e implementar ações que façam a ligação entre eventos nesse futuro possível e o presente;

vi. Identificar, analisar e monitorar mudanças que tenham ocorrido.

Modelo de trabalho proposto por Slaughter (2003, pp.59-62):

i. Detecção de objeto de estudo de importância;

ii. Investigação (pesquisa) deste tópico durante determinado período;

iii. Desenvolvimento de conclusões iniciais (análise e raciocínio);

iv. Discussão das conclusões com especialistas;

v. Construção de projeto e apresentação de proposta;

vi. Persistência, em face à indiferença ou oposição;

vii. Avaliação dos resultados.

Ambos os modelos sugerem uma combinação das ferramentas descritas anteriormente, dentro dos limites delineados pelo objeto de estudo escolhido e também, um elemento de orientação prospectiva nesses trabalhos. Dessa forma, os dois modelos reforçam a necessidade de transformar o trabalho com os estudos do futuro em ação para o futuro. Naturalmente, o âmbito de cada projeto dependerá de cada circunstância educacional (escola, professor, aluno, nível) e dessa forma, ele poderá ou não incluir todas as fases. No entanto, nos pareceu relevante a escolha desses modelos como forma de ressaltar a importância de um ciclo nesse tipo de projeto, de maneira que o despertar desse 'discurso futuro" seja, o mais freqüentemente possível, ligado à noção de uma ação voltada a esse futuro. Acreditamos que tal importância esteja justificada pelo possível caráter psicológico do trabalho com os estudos do futuro, que discutiremos a seguir. 


\subsection{POR UMA PSICOLOGIA DO FUTURO?}

Como vimos anteriormente, as visões de futuro dos jovens podem refletir aspectos positivos ou negativos destes. Baseados nisso e lembrando a afirmação de Hicks em relação à importância que a nossa auto-imagem pode vir a ter em relação ao nosso futuro (onde ele sugeria existir um elemento de uma "profecia auto-realizável" nesse sentido) poderíamos concluir que o trabalho com os estudos do futuro provoca conseqüências de natureza psicológica em seus participantes ou, nas palavras de Rogers “...parece bastante óbvio dizer que o primeiro passo que temos de reconhecer é que aprender sobre questões globais e futuros alternativos envolve emoções e reflexões pessoais" (1998, p.35).

Uma boa parte das discussões relacionadas aos aspectos psicológicos do trabalho com os estudos do futuro feita por Kauffmann (1976, pp.43-48) baseia-se na hierarquia de necessidades proposta por Maslow ${ }^{19}$. Ao defender a implementação dos estudos do futuro nas escolas, Kauffman sugere que tal abordagem pode produzir indivíduos mais aptos a vivenciar a auto-realização sugerida por Maslow, já que teriam confiança na imagem que fazem de si mesmos; seriam menos "absolutistas" e mais dados à experimentação. Tais indivíduos, assim, responderiam melhor ao alerta de Toffler em relação ao futuro: estariam prevenidos e preparados para ele.

Contudo, segundo Gidley (2004) poucas foram as investigações no sentido de explorar os efeitos psicológicos do trabalho com os estudos do futuro, além do trabalho realizado por Rogers e Tough (1998). Ainda que o trabalho de Gidley tampouco apresente uma investigação profunda dos aspectos psicológicos relacionados aos estudos do futuro, ele traz outra contribuição particularmente importante ao integrar o trabalho de natureza de análise de fatores culturais e em

19 Segundo Maslow, as necessidades humanas estão organizadas em uma hierarquia piramidal, indo das mais básicas, ou "animais" (porque fisiológicas) na base, subindo para as mais distintamente humanas (afeição, auto-estima) e culminando com as necessidades de autorealização no topo. 
diferentes camadas proposto por Sohail Inayatullah (2005) com o trabalho com um "modelo integralista de estudos do futuro" ${ }^{20}$ para propor uma estrutura de Todos os Quadrantes/ Todos os Níveis inspirada na estrutura semelhante proposta pelo psicólogo Ken Wilber. O modelo de Wilber baseia cada quadrante em uma escola de ciências sociais ${ }^{21}$, cuja discussão detalhada, naturalmente, vai além do escopo deste trabalho. Apesar do modelo de Wilber ainda ser alvo de debates, ele nos parece também funcional na representação das dimensões interiores e exteriores do individuo e da coletividade que podem orientar o trabalho em diferentes níveis com os estudos do futuro, e que, para efeito prático, resumiremos aqui:

i. Superior Esquerda - Aspectos interiores do indivíduo (intencionais, psicológicos)

ii. Superior Direito - Aspectos exteriores do indivíduo (comportamentais, físicos)

iii. Inferior Esquerdo - Aspectos interiores do coletivo (sistemas de significado, culturais)

iv. Inferior Direito - Aspectos exteriores do coletivo (sistemas sociais, sociedade)

Segundo esta ótica, podemos concluir que a maior parte das pesquisas sobre a implementação dos estudos do futuro em escolas realizadas até o momento parece apontar para os dois quadrantes superiores, ou seja, a introdução de conceitos e ferramentas que influenciarão o conhecimento do individuo (Superior Esquerdo) e seu comportamento (Superior Direito). Em menor número, estariam as pesquisas ligadas aos quadrantes do coletivo, culturais (Inferior Esquerdo) e Sociais (Inferior Direito).

Em um trabalho que inicialmente abordasse as visões de futuro dos professores antes de que estes possivelmente iniciassem o trabalho com alunos,

20 Tal modelo baseia-se no modelo proposto por Kieran Egan e Robert Kegan a partir da análise de obra de Wilber.

$21 \quad$ No caso específico, a teorias de Freud (Superior Esquerdo), Skinner (Superior Direito), Gadamer (Inferior Esquerdo) e Marx (Inferior Direito que ofereceriam perspectivas complementares e não contraditórias à existência humana, segundo Wilber. 
uma das probabilidades é que surgiriam dados ou indícios que apontassem para pesquisas posteriores de maior caráter psicológico. Além disso, caso o trabalho com alunos fosse realizado após a investigação de visões dos professores e de sua familiarização com as ferramentas dos estudos do futuro, teríamos então alguns elementos de todos os quadrantes, pois existiram informações sobre os indivíduos (tanto alunos como professores) como do coletivo (como as escolas e o sistema escolar em questão percebem a implementação dos estudos do futuro). A combinação desses quadrantes, portanto, nos parece ideal para atingir os objetivos da educação para o futuro propostos por McDaniel (1980,p.103):

1- lidar com as questões de sua sociedade;

2- entender a si mesmos;

3- entender seu compromisso com o futuro;

4- obter uma sensação de poder sobre seus futuros;

5- identificar-se com a sociedade que herdarão;

6- compreender a natureza das mudanças;

7- ver maneiras de afetar a direção das mudanças;

8- entender conceitos-chave relacionados à ciências sociais e suas relações com as mudanças;

9- identificar os papéis que podem assumir nesse processo de mudança;

10-evitar o etnocentrismo;

11-incorporar o ambiente da sala de aula aos ambientes de aprendizado dos ambientes ao seu redor;

12-transferir o aprendizado da sala de aula para responsabilidades futuras;

13-auxiliar indivíduos mais maduros a criar situações de aprendizado relevante;

14-compreender o papel desses indivíduos mais maduros no processo de mudança; 
15-desenvolver laços e uma conexão maior com indivíduos mais maduros;

16-transformar instituições imaturas.

\subsection{CONCLUSÃO}

As preocupações, por parte de vários educadores, relacionadas ao preparo das gerações futuras para lidar com as questões do futuro já encontraram eco em diversos experimentos voltados aos estudos do futuro, nas escolas de ensino fundamental e médio em diversos países. Em contrapartida, ainda são poucos os cursos voltados à formação de professores para o trabalho com os estudos do futuro (e, conseqüentemente, poucas informações sobre as atitudes destes em relação ao futuro). Em boa parte desses projetos verifica-se a intervenção governamental na introdução de reformas curriculares que explicitem um caráter de abordagem do "futuro" em seus conteúdos. Mesmo sem conhecer alguma abordagem explicita nesse sentido em escolas brasileiras para efeito de comparação, os estudos realizados em outros paises sugerem que o trabalho com diferentes perspectivas de futuro tende a ser fonte de grande motivação para os jovens e que estes, sem tal tipo de trabalho voltado à descoberta de alternativas, muitas vezes desenvolvem atitudes negativas ou de pouca esperança em relação ao futuro.

Vários desses estudos investigam as atitudes dos jovens em relação ao futuro, de forma a oferecer subsídios para a elaboração de programas educacionais. Outros estudos apresentam diferentes ferramentas para os estudos do futuro dentro de projetos de caráter multidisciplinar em escolas. As diferentes ferramentas são categorizadas por seu grau de complexidade e relevância, podendo assim ser relacionadas ao tipo de trabalho já realizado com os alunos. A preocupação principal da maioria de tais projetos não é a transmissão de conteúdos relacionados aos estudos do futuro para que estes jovens se transformem em estudiosos do futuro (denominação ainda típica do 
nível superior, ao que nos parece). Tais projetos desejam, na realidade, despertar uma consciência mais explícita entre fatos passados, presentes e futuros, e desenvolver uma competência ou discurso futuro por parte desses jovens. Assim, seu objetivo maior se torna a preparação para identificar possíveis alternativas para seus futuros, capacitando-os a direcionar seus esforços em relação a uma visão de futuro almejada e às ações de transformação do mundo ao seu redor nesse sentido. 


\section{ENSINANDO O FUTURO}

\subsection{METODOLOGIA DA INVESTIGAÇÃO}

Antes de iniciarmos a descrição das diferentes etapas envolvidas no projeto de pesquisa deste trabalho, é conveniente introduzi-las através de uma breve referência às informações obtidas e apresentadas nos capítulos anteriores.

Em primeiro lugar, foi possível observar evidências de que a preocupação com os eventos futuros parece ser mais ou menos inerente à experiência humana. Desde a antiguidade até os nossos dias, o homem procura "antecipar" seu destino, seja por questões de planejamento, segurança ou estabilidade. No entanto, a abordagem de caráter divinatória de outros tempos começou a ser substituída por outras abordagens, em meados do século XIX e depois, no século XX (um século possivelmente marcado por mudanças profundas e em grande quantidade, e até certo ponto, de caráter e intensidade e inesperado, como as duas grandes guerras). Beneficiados com 0 desenvolvimento em paralelo de outras ciências, surgem os primeiros estudos do futuro de caráter mais sério, voltados a apontar possíveis caminhos ou alternativas para o desenvolvimento das sociedades no pós-guerra. Apesar de emprestarem técnicas, conceitos e princípios epistemológicos de outras ciências sociais, tais estudos enfrentam ainda hoje uma certa dificuldade no sentido de serem aceitos como "ciência" ou "arte", possivelmente derivada da própria visão almejada de futuro exibida pelos profissionais da área. O principal obstáculo enfrentado para sua aceitação diz respeito ao seu objeto de estudo, uma vez que o futuro ainda "não aconteceu". Em contra partida, profissionais do setor alegam que o estudo de fatos históricos do passado é feito através da interpretação de registros, uma vez que o passado "já aconteceu" e não pode ser reproduzido, como outro fato científico, por exemplo. 
Essa dicotomia aparentemente existente entre as abordagens parece mais obscurecer a qualidade dos trabalhos realizados do que realmente apontar para uma de suas vantagens inegáveis: a criação de uma consciência (ou discurso futuro, segundo Slaughter), que nos permita não só compreender o passado e o presente dentro de uma ótica voltada ao futuro, mas também conceber alternativas para este futuro e nos preparar para o desenvolvimento desta ou aquela alternativa e não conceber um futuro apenas, inevitável e inescrutável por definição.

Em segundo lugar, verificamos que a educação brasileira sofreu uma série de mudanças em sua estrutura o longo dos 500 anos de história da nação. Desde os primeiros anos da colonização, fica mais ou menos evidente a pouca preocupação com os graus de formação básica, sendo que os esforços ao longo dos séculos privilegiaram as formas de acesso ao ensino superior. Dessa forma, nos parece que uma das principais funções do ensino, que seria a preparação para a vida adulta em sociedade, recebeu pouca atenção explícita nesse sentido nos graus elementares da educação: o ensino médio público "oficializado" surge somente na metade do século XIX e o ensino primário somente é estruturado de maneira a ser integrado com os outros níveis em meados do século XX. Juntando-se a estes fatores, as diferentes mudanças de caráter administrativo na história do país resultaram em um processo de ruptura quase que constante em relação à formação de uma tradição pedagógica brasileira, ao contrário do ensino de outros países, por exemplo. Se, por um lado, tal ruptura sugere uma renovação constante dos processos de ensino, por outro, ela dificulta o desenvolvimento de processos de longo prazo, com diferentes gerações tendo vivenciado diferentes sistemas de ensino e abordagens curriculares. Isso termina por refletir na agilidade e flexibilidade das instituições em implementar inovações curriculares concebidas pelas próprias instituições, uma vez que o objetivo geral da educação brasileira (no caso, o acesso ao ensino superior) permanece o mesmo.

As últimas reformas, no entanto, datadas do final do século $\mathrm{XX}$, criam o 
mecanismo dos Parâmetros Curriculares Nacionais, que visa a "informar" a abordagem de conteúdos de modo que as diferentes áreas sejam trabalhadas transversalmente, seguindo uma orientação voltada à formação do individuo para a vida em sociedade e à sua preparação com as mudanças vividas por essa sociedade. Tais parâmetros ainda sugerem a busca por "novas alternativas e abordagens pedagógicas", o que faz com que uma abordagem mais explicita das questões relacionadas ao futuro pareça não só uma abordagem pedagógica viável mas também pertinente no atual momento. No entanto, um processo de inovação curricular, iniciado pelos próprios agentes diretos da educação, coordenadores, professores e alunos nos parece indicar uma abordagem com mais chances de sucesso. Como parte desse processo de inovação curricular ele não teria um caráter "vertical" e de imposição, típico das reformas curriculares vividas ao longo da história da educação brasileira.

Em terceiro lugar, pudemos também verificar que experimentos voltados aos estudos do futuro nas escolas de ensino fundamental e médio não são uma novidade em diversos países. Apesar de existirem poucos cursos voltados à formação de professores para o trabalho com os estudos do futuro (e, conseqüentemente, poucas informações sobre as atitudes destes em relação ao futuro), projetos governamentais introduziram reformas curriculares explicitando um caráter de abordagem "futura" em seus conteúdos. Ainda que não conheçamos nenhuma abordagem explicita nesse sentido em escolas brasileiras para efeito de comparação, os estudos realizados em outros paises sugerem que o trabalho com diferentes perspectivas de futuro tende a ser fonte de grande motivação para os jovens e que estes, sem tal tipo de trabalho voltado à descoberta de alternativas, muitas vezes desenvolvem atitudes negativas ou de pouca esperança em relação ao futuro.

Uma boa parte desses estudos investiga as atitudes dos jovens em relação ao futuro, de forma a oferecer subsídios para a elaboração de programas educacionais. Uma outra parte desses estudos apresenta diferentes ferramentas para os estudos do futuro dentro de projetos de caráter multidisciplinar em 
escolas. As diferentes ferramentas são apresentadas em um grau de complexidade e relevância relacionado ao tipo de trabalho já realizado com os alunos e, na maior parte das vezes, não indicam uma preocupação em formar tais jovens como estudiosos do futuro (ainda aparentemente sob o domínio da universidade), e sim despertar uma consciência mais explícita entre fatos passados, presentes e futuros, de forma a desenvolver uma competência ou discurso futuro por parte desses jovens, preparando-os não só para identificar possíveis alternativas para seus futuros, mas também, dentro do possível, para direcionar seus esforços em relação a uma visão de futuro almejada.

Dessa maneira, nos parece que a realização de pesquisas semelhantes envolvendo alunos de ensino fundamental ou médio em escolas brasileiras já traria, por si só, um aspecto de ineditismo. Contudo, ao invés de simplesmente reproduzir a natureza das pesquisas já realizadas com os alunos desses níveis, nos pareceu particularmente relevante alterar a organização destas. O primeiro destes pólos, o sistema educacional brasileiro atual, no presente momento não favoreceria o desenho e implementação de um currículo voltado aos estudos do futuro de caráter oficial: tal empreitada iria além do escopo deste trabalho. Ainda, mesmo que levada a cabo, tal realização poderia se constituir em outro instrumento de caráter impositivo na atuação de professores e, pelo que já foi levantado, exigiria um grau de preparação formal dos professores para lidar com essas questões ainda não oferecido em seus cursos de formação.

Por outro lado, a estrutura educacional brasileira atual, dentro dos Parâmetros Curriculares Nacionais, favorece o uso de abordagens alternativas na formação dos futuros cidadãos através de projetos interdisciplinares que utilizam os chamados "temas transversais" (por exemplo, saúde, meio ambiente, diversidade). Como veremos adiante, tais áreas são também objeto de preocupação dos estudos do futuro, o que, dessa forma, permitiria uma união mais equilibrada do trabalho a ser realizado pelos professores com a nova abordagem proposta.

No entanto, o fato de que os professores provavelmente não possuem 
treinamento específico para lidar com uma abordagem ligada aos estudos do futuro sugere que uma investigação das atitudes destes em relação às questões do futuro seja de importância fundamental, já que, como agentes do processo de inovação curricular, serão eles os responsáveis pelo despertar e desenvolvimento da consciência dos jovens nesse sentido. Tal investigação das atitudes dos professores com relação às questões do futuro também se mostra relevante em relação às pesquisas internacionais já realizadas, pela escassez de trabalhos com esse objetivo específico. Desse modo, esta pesquisa poderia trazer um outro ângulo, o dos profissionais do ensino, e mostrar de que maneira estes se identificam e se preocupam com tais questões, ainda que um trabalho paralelo não seja realizado com os alunos de forma explícita.

Colocando a questão da inovação curricular e das condições necessárias para sua implementação ao lado das atitudes dos professores em relação às questões do futuro, podemos perceber que as etapas dessa pesquisa terão de ser organizadas de maneira progressiva, de forma que quaisquer experimentos ligados aos estudos do futuro com alunos, caso sejam efetivamente realizados, deverão obrigatoriamente passar pelo crivo e aceitação de professores e estabelecimentos de ensino. Assim, constituiriam exemplos mais genuínos de um processo de inovação curricular e forneceriam subsídios mais verdadeiros para futuras pesquisas. A pesquisa optará também por concentrar sua investigação nas escolas de Ensino Médio, devido ao maior número de ferramentas ligadas aos estudos do futuro disponíveis dentro das capacidades cognitivas dos alunos nessa faixa etária, e, em um paralelo com outras pesquisas internacionais já realizadas, pelo fato de que seria possivelmente nessa faixa etária, a mais próxima do ingresso na vida "adulta" e "profissional", que os jovens demonstrariam maior preocupação e consciência em relação às questões do futuro, ao mesmo tempo em que exibiriam menor interesse e capacidade de ação para lidar com os aspectos negativos dessas questões.

Levando em consideração, então, os pontos mencionados anteriormente, a pesquisa será organizada da seguinte forma: 
1- $\quad$ Contato inicial com diferentes estabelecimentos de Ensino Médio da cidade de São Paulo, tanto de natureza privada quanto pública, para apresentação do projeto. O contato será feito através da direção ou coordenadoria pedagógica de cada estabelecimento, seguido da apresentação do projeto como um todo e da requisição de permissão para realização de pesquisa de caráter quantitativo e qualitativo (questionários) a serem distribuídos e respondidos pelos professores do Ensino Médio de tais estabelecimentos. O objetivo dessa etapa inicial é a obtenção do maior número de respostas possíveis para que os resultados constituam uma amostragem relevante das atitudes dos professores em relação às questões do futuro;

2- Dentro do interesse e da disponibilidade demonstrados por diretores, coordenadores e professores de cada estabelecimento, oferecer sessões de familiarização sobre o que seriam os estudos do futuro e de quais maneiras estes poderiam ser introduzidos em atividades ou projetos já existentes em seus estabelecimentos. Um segundo questionário sobre sua compreensão e suas atitudes em relação à introdução dos estudos do futuro em sua prática pedagógica, de caráter tanto quantitativo como qualitativo, seria então distribuído aos participantes dessas sessões. O objetivo é identificar a relevância de tal trabalho com os alunos por parte dos professores, ao mesmo tempo em que as respostas obtidas serviriam para apontar as ferramentas e conceitos que exigiriam um grau maior de preparação dos professores nesse sentido;

3- $\quad$ Finalmente, junto aos estabelecimentos que decidissem pela 
implementação de um ou vários aspectos ligados aos estudos do futuro, acompanhar os professores nessa implementação para orientar suas atividades da maneira mais indireta possível, uma vez que o processo de inovação curricular dependeria sobretudo destes. Caso estes projetos ocorram, o objetivo é coletar o maior número de informações relacionadas à implementação destes para a formação de um referencial descritivo dos experimentos realizados.

Acreditamos ser importante dividir a pesquisa dessa forma pelos seguintes motivos:

i- ainda que a relevância das questões do futuro seja provavelmente percebida e o trabalho nesse sentido interesse aos professores participantes, poderão existir condições adversas à implementação de tal abordagem. Dessa forma o questionário inicial já ofereceria resultados estatísticos relevantes em relação a outros projetos dessa natureza a serem realizados;

ii- mesmo sendo possível a realização das sessões de familiarização sobre os estudos do futuro com os professores, isso também não garantiria a implementação de projetos junto aos alunos. No entanto, o segundo questionário forneceria dados estatísticos adicionais em relação ao objeto de estudo desta pesquisa sem si, a introdução dos estudos do futuro nas escolas de Ensino Médio e portanto, poderia apontar obstáculos e alternativas para sua implementação;

iii- $\quad$ por fim, em respeito à natureza dos processos de inovação curricular e da conseqüente livre escolha e implementação das ferramentas para os estudos do futuro (apresentadas nas sessões de familiarização), em projetos que porventura ocorram, 
os resultados dessas empreitadas constituiriam naturalmente um corpo de análise mais diverso em sua extensão, amplitude e foco, tornando-se assim de caráter mais qualitativo e ilustrativo, caracterizando uma espécie de apêndice aos resultados encontrados nas duas fases iniciais.

\subsection{ATITUDES DOS PROFESSORES EM RELAÇÃO ÀS QUESTÕES DO FUTURO: INSTRUMENTO DE PESQUISA}

A ferramenta escolhida para a investigação das atitudes dos professores em relação às questões do futuro foi um questionário com respostas de múltipla escolha. Tal questionário usou como modelo o questionário desenvolvido por Tonn, Conrad e Hemrick (2004) para avaliar as percepções envolvendo questões do futuro e de risco em uma pesquisa realizada via Internet. Eles tinham como pressupostos alguns conceitos que foram também considerados no desenho do questionário aplicado nessa pesquisa:

i. pessoas não envolvidas nos estudos do futuro podem também ter concepções ricas sobre o futuro que os profissionais da área ainda não compreendem ou consideram;

ii. a palavra 'futuro' seria interpretada por aqueles não envolvidos nos estudos do futuro como algo muito mais próximo ao presente do que aquilo presumido pelos profissionais da área;

iii. o futuro mais próximo do momento atual estaria mais presente nas idéias dos respondentes, assim como em suas preocupações;

iv. os respondentes seriam capazes de imaginar um futuro "sombrio" em determinado ponto cronológico; 
v. os respondentes seriam ou otimistas ou pessimistas por natureza;

vi. os respondentes apoiariam o planejamento de futuros mais próximos ao presente do que aqueles mais distantes cronologicamente;

vii. os respondentes confirmariam que a humanidade em geral não aborda as questões relacionadas ao futuro de modo responsável;

viii.incerteza relacionada ao número de respondentes que gostariam de viver no futuro ou que acreditam que a humanidade se extinguirá.

Foram também incluídos setores demográficos no questionário relacionados ao sexo, idade e afiliação religiosa. No entanto, como os respondentes de nossa pesquisa teriam a categoria profissional como elemento comum, foram incluídas categorias relacionadas à experiência como educadores e seu grau de formação nesse sentido. Discutiremos brevemente agora as categorias demográficas envolvidas na pesquisa:

\section{A-Sexo}

Em termos gerais, não existiram pressupostos relacionados ao sexo e atitudes em relação às questões do futuro. Em outras pesquisas, existe uma certa inferência de que as mulheres tenderiam a se preocupar mais e ser menos otimistas com relação ao futuro. Caso isso prove ser verdadeiro em nossa pesquisa, será possivelmente um achado relevante, uma vez que o magistério ainda tende a concentrar um número maior de mulheres.

\section{B- Idade}

Como já dito anteriormente, diversas pesquisas anteriores (Hicks, 1996; Gidley, 1998) concentram-se nas imagens dos jovens em relação ao futuro. Em geral, os mais jovens tendem a ser mais otimistas em relação aos seus futuros pessoais e mais pessimistas em relação ao futuro do planeta. Como nossa pesquisa envolverá pessoas de diversas faixas etárias, poderemos verificar se tal pressuposto também se aplica às diferentes gerações de profissionais. 


\section{$\underline{\text { C- Experiência como educador }}$}

Esta categoria foi incluída em nossa pesquisa com o intuito de verificar não só de que maneira os anos de experiência profissional no ensino de jovens podem afetar as atitudes em relação ao futuro, assim como verificar (através do cruzamento com outras respostas) de que maneira tais profissionais percebem a capacidade dos jovens e do sistema educacional como um todo para preparar as novas gerações para lidar com tais questões.

\section{D- Formação profissional}

Esta categoria também foi incluída em nossa pesquisa, de forma a obter maiores informações sobre a relevância ou não do grau de formação profissional nas atitudes ou interesse dos profissionais em relação às questões do futuro, já que, como mencionado anteriormente, uma formação específica dos profissionais para o trabalho com essas questões usando ferramentas e métodos utilizados nos estudos do futuro ainda é incipiente no país.

\section{E-Religião}

A questão religiosa foi abordada de modo genérico em nossa pesquisa. Os respondentes deverão apenas indicar quais são suas afiliações religiosas e não necessariamente o quão profundamente detém suas crenças ou praticam suas religiões. Ainda assim, o pressuposto aqui é de que aqueles que crêem que um ser ou uma força sobrenatural determina seus destinos estariam mais inclinados a pensar e a se preocupar menos com o futuro do que aqueles que não crêem (McFaul, 2006).

No caso das perguntas específicas da pesquisa em si, utilizamos as mesmas perguntas da pesquisa original, acrescidas de duas perguntas relacionadas à vivência dos respondentes como profissionais da educação e de suas percepções em relação à capacidade dos jovens para lidar com tais questões. Grande parte das perguntas oferecia a oportunidade de respostas 
numéricas que indicassem o grau de concordância ou discordância em relação às perguntas efetuadas. Discutiremos brevemente agora as diferentes perguntas existentes no questionário:

I- Noção de tempo relacionado à palavra "futuro": são oferecidas aqui três janelas de tempo aproximado (menos de 30, entre 30 e 50 e mais de 50 anos) com o intuito de verificar o quão próximo do momento presente os respondentes vêem seu futuro pessoal;

II- Freqüência de pensamento em relação a diferentes períodos futuros: são apresentados aqui seis momentos futuros e os respondentes devem indicar com que freqüência (muita, alguma, pouca, nenhuma) pensam neles;

II I- Grau de preocupação em relação a diferentes períodos futuros: os mesmos momentos do futuro da pergunta anterior são apresentados para que os respondentes indiquem seu grau de preocupação (muita, alguma, pouca, nenhuma) em relação a estes;

IV- $\quad$ Grau de clareza em relação a uma visão de futuro: dez diferentes períodos futuros são apresentados para que os respondentes indiquem o grau de clareza (muita, alguma, pouca, nenhuma) em sua percepção destes. O acréscimo de outros momentos futuros visa a estender o escopo das respostas para além dos períodos voltados ao futuro pessoal das perguntas anteriores, focando agora no futuro da humanidade;

V- $\quad$ Sentimentos em relação ao futuro: os mesmos dez diferentes períodos futuros são apresentados para que os respondentes indiquem seus sentimentos (muito, algum, pouco ou nenhum otimismo) em relação a estes;

VI- $\quad$ Grau de preparação ativa da humanidade para o futuro: mais uma vez os mesmos dez diferentes períodos futuros são 
apresentados para que os respondentes indiquem 0 que acreditam ser o grau de preparação necessário (alto, médio, baixo, nulo) da humanidade para tais períodos;

VII - Grau de responsabilidade da humanidade em relação às questões do futuro: são apresentadas dezesseis áreas de interesse para que os respondentes indiquem o que acreditam ser o grau de responsabilidade atual da humanidade (alto, médio, baixo, nulo) da humanidade em relação a cada um deles;

VIII- Grau de preparação dos jovens em idade escolar para lidar com tais questões do futuro: essa pergunta foi incluída no questionário com o intuito de estabelecer de que forma genérica os profissionais de ensino percebem a preparação atual dos jovens (alta, media, baixa, nula) em relação às áreas apresentadas na pergunta anterior;

IX - $\quad$ Freqüência de oportunidades no sistema escolar para preparar os jovens para lidar com tais questões do futuro: essa pergunta também foi incluída no questionário com o intuito de estabelecer de que forma genérica os profissionais de ensino percebem o espaço das questões do futuro e da preparação dos jovens (alta, média, baixa, nula) para estas dentro de sua prática atual no sistema escolar;

X- Opiniões sobre diversos aspectos do futuro: os respondentes devem indicar seu grau de concordância (concordância plena ou parcial, discordância parcial ou absoluta) em relação a afirmações sobre o futuro de cunho pessoal ou da humanidade como um todo;

XI- Escolha de um futuro para "viver": nove períodos distintos no futuro são apresentados para que os respondentes escolham um no qual gostariam de "nascer". A disparidade entre os diferentes 
períodos existe para verificar de que forma os respondentes vêem esses períodos futuros dentro de uma cronologia semelhante àquela que poderiam utilizar para períodos passados;

XII, XIII e XIV - Crença sobre a extinção da humanidade e seus fatores: os respondentes respondem aqui se acreditam que a humanidade, como a conhecemos, um dia será extinta e, na pergunta subseqüente, escolhem um dos períodos apresentados para a data de extinção desta. Na última pergunta, eles podem escolher um ou mais fatores que, em sua opinião, levarão ao fim da humanidade.

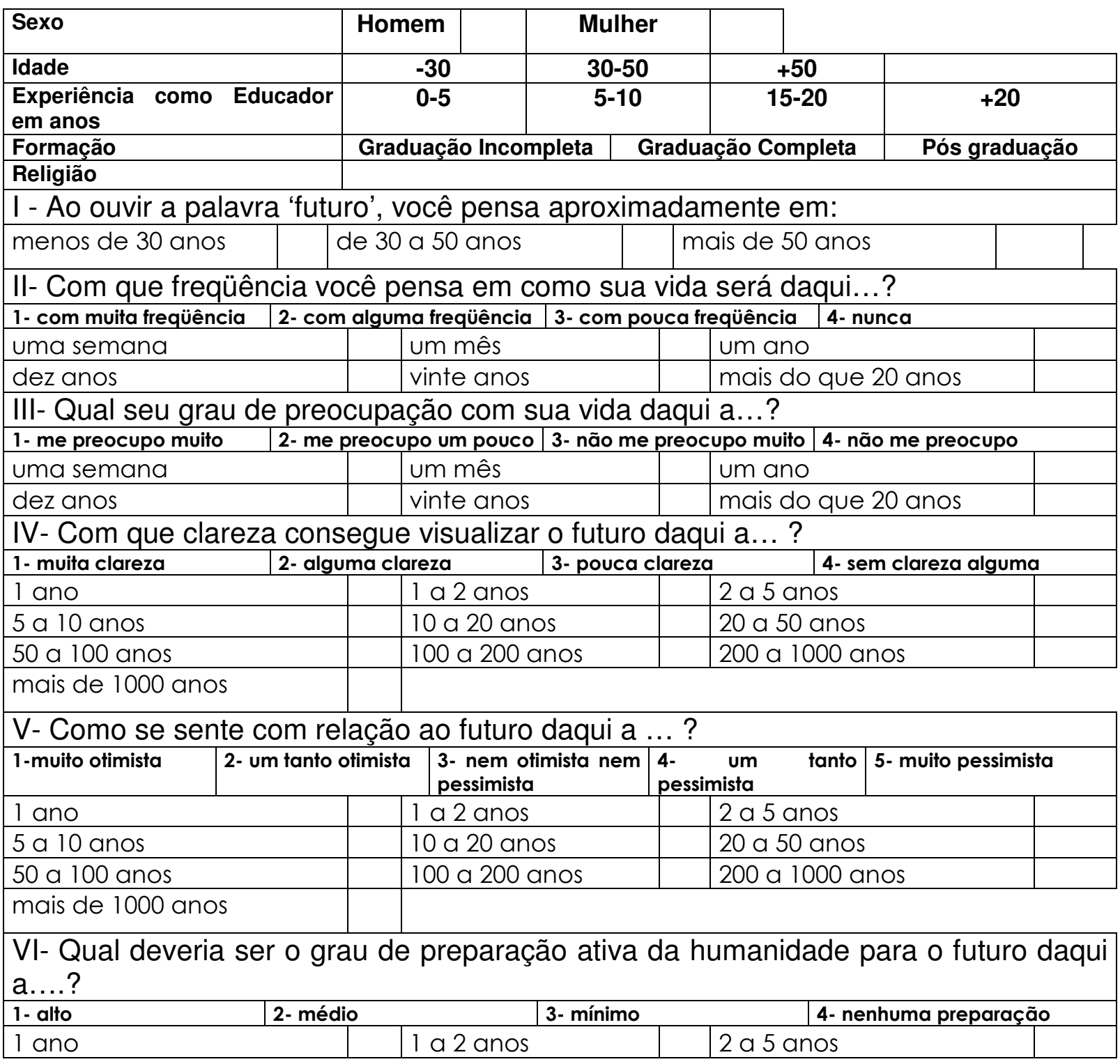




\begin{tabular}{|c|c|c|c|c|c|}
\hline \multirow{3}{*}{\begin{tabular}{|l|}
5 a 10 anos \\
50 a 100 anos \\
mais de 1000 anos \\
\end{tabular}} & 10 a 20 an & & \multicolumn{2}{|c|}{20 a 50 anos } & \\
\hline & 100 a $200 c$ & inos & \multicolumn{2}{|c|}{200 a 1000 anos } & \\
\hline & \multicolumn{4}{|c|}{ 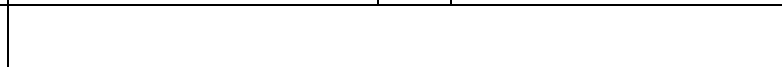 } & \\
\hline \multicolumn{6}{|c|}{$\begin{array}{l}\text { VII- Como julgaria o grau de responsabilidade atual da humanidade no que diz } \\
\text { respeito a questões futuras como...? }\end{array}$} \\
\hline 1- muito responsável & 2- um pouco responsável & \multicolumn{2}{|c|}{ 3- não muito responsável } & \multirow{2}{*}{$\begin{array}{l}\text { 4- nada responsável } \\
\text { lidade }\end{array}$} & \\
\hline Aquecimento Global & Biodiversid & & Espiritu & & \\
\hline Energia & Educação & & Econo & & \\
\hline Qualidade da Água & Qualidade & de Vida & Polítice & & \\
\hline Quantidade de Água & Paz e Segu & ança & Novas & ecnologias & \\
\hline
\end{tabular}

Tabela 4- Questionário usado na 1.a fase da investigação (página 1) VIII- Na sua opinião, qual o grau de preparação dos jovens em idade escolar para lidar com essas questões do futuro?

1- alto

2- médio

3- baixo

4preparação

sem

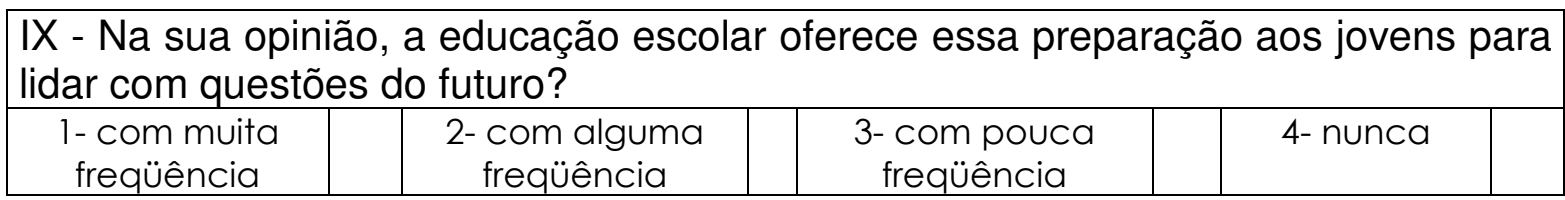

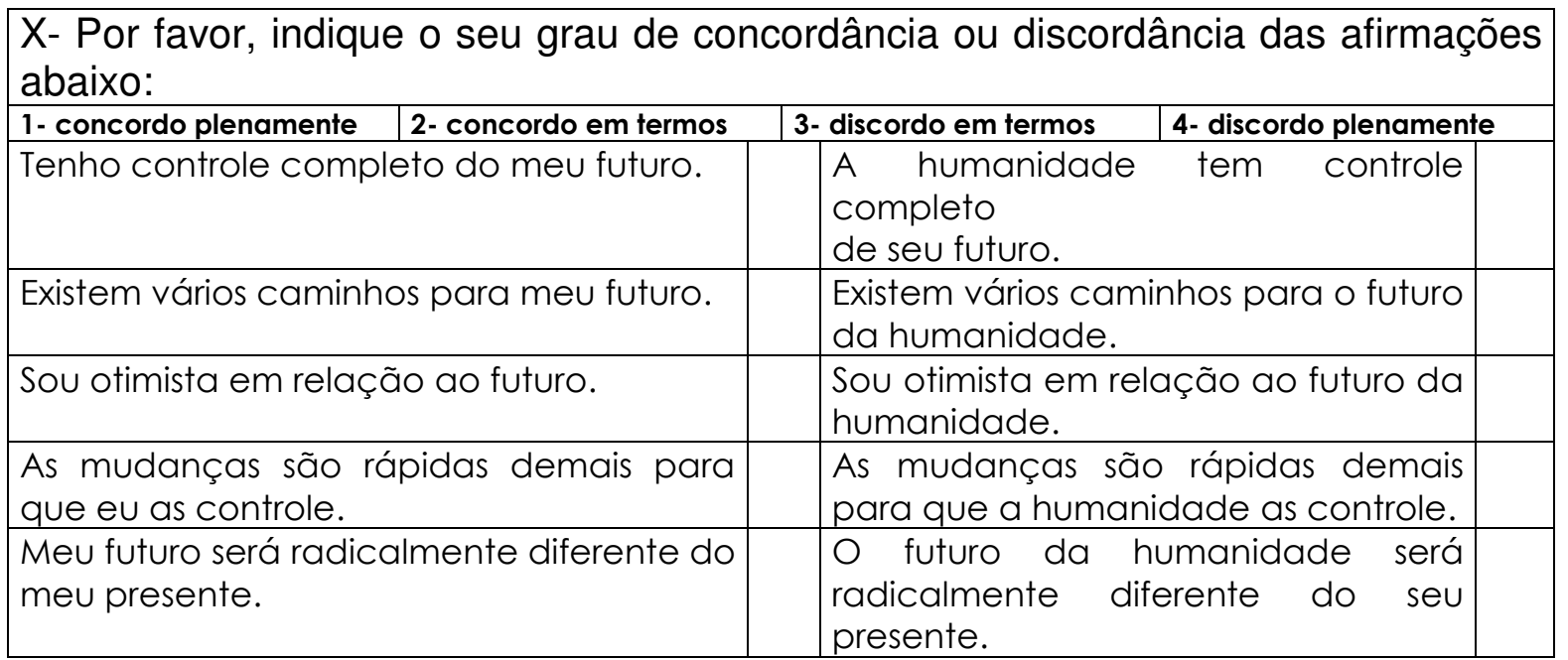

\begin{tabular}{|l|l|l|l|}
\hline IX-Caso pudesse nascer no futuro, indique quando gostaria de nascer: daqui a \\
\hline 1 ano & 10 anos & 50 anos \\
\hline 100 anos & 500 anos & & 1000 anos \\
\hline 5000 anos & 10.000 anos & 100.000 anos \\
\hline
\end{tabular}

\begin{tabular}{|l|l|l|l|l|}
\hline X- Acredita que a humanidade um dia se extinguirá? & Sim & & Não & \\
\hline
\end{tabular}




\begin{tabular}{|l|l|l|l|l|}
\hline XI- Quando a humanidade se extinguirá? & \\
\hline não sei & 10 anos & 50 anos & \\
\hline 100 anos & 500 anos & 1000 anos & \\
\hline 5000 anos & 10.000 anos & 100.000 anos ou mais & \\
\hline
\end{tabular}

\begin{tabular}{|l|l|l|l|l|}
\hline XII- Por que a humanidade se extinguirá? (Assinale uma ou mais respostas) \\
\hline Conflitos religiosos & $\begin{array}{l}\text { Degradação } \\
\text { ambiental }\end{array}$ & Extinção Natural & \\
\hline Evolução & & Guerras & Fim dos recursos naturais & \\
\hline Superpopulação & & Desastres Naturais & Doenças /epidemias & \\
\hline Mudança Climática & & Outros & Não sei & \\
\hline
\end{tabular}

Tabela 5- Questionário usado na 1.a fase da investigação (página 2)

\subsection{APRESENTANDO OS ESTUDOS DO FUTURO PARA OS PROFESSORES DO ENSINO MÉDIO}

A ferramenta escolhida usada para familiarizar os professores em relação aos estudos do futuro foi uma oficina ou "workshop" conduzida pelo pesquisador, a ser realizada em datas convenientes à direção/ coordenação das escolas e ao calendário dos professores. Apesar da vasta quantidade de informações disponíveis em relação ao que seriam os estudos do futuro e de que maneiras eles podem ser realizados, procuramos optar por um formato o mais breve possível que atendesse aos seguintes objetivos:

i. esclarecer a natureza e a importância dos estudos do futuro;

ii. apresentar conceitos-chave e uma tipologia funcional relacionados aos estudos do futuro;

iii. apresentar áreas de interesse voltadas ao trabalho com os estudos do futuro;

iv. apresentar ferramentas relacionadas aos estudos do futuro que poderiam ser aplicadas por jovens do Ensino Médio;

v. ressaltar a natureza de inovação curricular no uso dessas ferramentas 
como possibilidade de trabalho multidisciplinar;

vi. discutir a relevância de tal abordagem no trabalho com esses jovens.

Dessa forma, a oficina adotou um formato em sua apresentação que privilegiasse o diálogo entre apresentador e participantes e também levasse em conta, sempre que possível, a experiência desses educadores no trabalho com as questões do futuro (mesmo que este fosse realizado de maneira implícita por parte deles). Descreveremos agora brevemente como os objetivos mencionados acima serão atingidos durante a apresentação.

1- Para esclarecer a natureza e a importância dos estudos do futuro, os participantes irão inicialmente discutir suas crenças sobre aquilo que acreditam ser estes estudos do futuro. Em seguida, apresentaremos informações que expliquem o que são estes estudos de acordo com a literatura existente, ressaltando sua importância para a melhor compreensão das rápidas mudanças em nossas vidas.

2- A apresentação dos conceitos-chave se concentrará na exposição e ilustração (através de exemplos) de noções relacionadas à teoria de sistemas, análise de tendências, consulta a especialistas e ao uso de cenários. Tal exposição ressaltará as maneiras através das quais os estudos do futuro oferecem a possibilidade de uma mudança de visão passado-presente, normalmente encontrada na educação, para uma visão passado-presente-futuro. Esta parte da oficina será concluída com a apresentação da tipologia de estudos do futuro sugerida por Gidley (2004), onde poderemos demonstrar de que maneira os conceitos- chave apresentados se combinam com paradigmas específicos, exemplos de projetos e "visões" de futuro (por exemplo, um, vários ou outro futuro).

3- A exposição incluirá as diferentes áreas de interesse (por exemplo, ciência e tecnologia, economia) e as relacionará a determinados temas 
(uso de tecnologia, saúde,diversidade cultural, por exemplo), reforçando a compatibilidade dessa abordagem no tratamento de temas possivelmente já abordados pelos professores, ressaltando a relevância dessa combinação de abordagem-tema como forma inovadora de trabalho em sala.

4- Serão apresentados diversos exemplos de atividades práticas isoladas a ser usadas em sala de aula (e que podem exigir maior ou menor grau de preparação por parte dos professores) com o intuito de demonstrar o caráter experimental de muitas delas (como a redação da história do futuro, por exemplo) e ressaltar sua flexibilidade e relevância na criação de um discurso futuro por parte dos alunos.

5- Em seguida, será apresentado o modelo de projeto para o trabalho com os estudos do futuro sugerido por Slaughter. A estrutura de tal modelo, a despeito do uso de diferentes ferramentas, pouco difere de um modelo de pesquisa clássico (o que pode se tornar um fator de aceitação por parte dos professores), mas a exposição ressaltará o caráter multidisciplinar e transversal típico dos projetos envolvendo os estudos do futuro.

6- Por fim, a apresentação discutirá a relevância desse tipo de trabalho com os jovens, reforçando a noção de que um maior grau de preparação para diferentes situações poderá ser de grande valia para os jovens prestes a ingressar em sua vida adulta.

As Tabelas 6- 11 mostram o plano elaborado para a apresentação da oficina, seguido dos slides com o conteúdo das diversas fases da oficina. 


\begin{tabular}{|c|c|c|c|c|}
\hline $\mathbf{E}$ & D & Objetivo & Int & Procedimentos \\
\hline 1 & 3 & $\begin{array}{l}\text { Introdução da } \\
\text { oficina }\end{array}$ & A/ P-P & $\begin{array}{l}\text { Mostrar Slide } 1 \text { pedir que os professores discutam } \\
\text { as afirmações nele. }\end{array}$ \\
\hline 2 & 8 & Discussão & A & $\begin{array}{l}\text { Mostrar Slide } 2 \text { e comparar as idéias dos } \\
\text { professores com as informações do Slide. }\end{array}$ \\
\hline 3 & $5^{\prime}$ & $\begin{array}{l}\text { Introdução do } \\
\text { tema da oficina }\end{array}$ & A/ P-P & $\begin{array}{l}\text { Mostrar Slide } 3 \text { e mencionar a data das frases } \\
\text { originais e sua contemporaneidade. }\end{array}$ \\
\hline 4 & $5^{\prime}$ & Exposição & A & $\begin{array}{l}\text { Explicitar as competências envolvidas nos estudos } \\
\text { do futuro. }\end{array}$ \\
\hline 5 & $5^{\prime}$ & $\begin{array}{l}\text { Exposição e } \\
\text { discussão }\end{array}$ & A/ Ps & $\begin{array}{l}\text { Discutir definições e pedir exemplos de diferentes } \\
\text { tipos de sistema }\end{array}$ \\
\hline 6 & $8^{\prime}$ & Exposição & A & $\begin{array}{l}\text { Apresentar exemplos de equilíbrio e desequilíbrio } \\
\text { em sistemas e o fator do "feedback" }\end{array}$ \\
\hline 7 & $5^{\prime}$ & $\begin{array}{l}\text { Discussão } \\
\text { E Esclarecimento }\end{array}$ & P-P & $\begin{array}{l}\text { Antes de mostrar o Slide, perguntar quais seriam } \\
\text { as diferenças de um Sistema Humano e um Natural }\end{array}$ \\
\hline 8 & $12^{\prime}$ & Exposição & A & $\begin{array}{l}\text { llustrar as perguntas do slide com exemplos e com } \\
\text { a ajuda dos professores }\end{array}$ \\
\hline 9 & $8^{\prime}$ & Exposição & A & $\begin{array}{l}\text { Esclarecer os diferentes níveis de "especialista" ou } \\
\text { grupo de interesse (pais, alunos, professores) }\end{array}$ \\
\hline 10 & $8{ }^{\prime}$ & $\begin{array}{l}\text { Exposição } \\
\text { E Esclarecimento }\end{array}$ & A & $\begin{array}{l}\text { Através de perguntas e exemplos, ilustrar cada um } \\
\text { dos itens do Slide. Reforçar as justificativas finais. }\end{array}$ \\
\hline 11 & $12^{\prime}$ & Discussão & A & $\begin{array}{l}\text { Apontar as diferentes áreas da tipologia. Entregar } \\
\text { cópia da tipologia aos professores. }\end{array}$ \\
\hline 12 & $10^{\prime}$ & Exposição & A/ P-P & $\begin{array}{l}\text { Mostrar as áreas de interesse e pedir exemplos } \\
\text { de atividades já realizadas pelos professores. }\end{array}$ \\
\hline 13 & $15^{\prime}$ & Exposição & A/ P-P & $\begin{array}{l}\text { Apresentar atividades usadas nos estudos do } \\
\text { Futuro, com exemplos baseados no trabalho já } \\
\text { feito. }\end{array}$ \\
\hline 14 & $3^{\prime}$ & Exposição & A & $\begin{array}{l}\text { Mostrar a estrutura de um projeto típico ressaltando } \\
\text { a semelhança com projetos habituais. }\end{array}$ \\
\hline 15 & $3{ }^{\prime}$ & Discussão & P-P & $\begin{array}{l}\text { Perguntar aos professores quais seriam as } \\
\text { vantagens desse tipo de trabalho. }\end{array}$ \\
\hline 16 & $5^{\prime}$ & $\begin{array}{l}\text { Discussão e } \\
\text { Conclusão }\end{array}$ & A & $\begin{array}{l}\text { Mostrar o último Slide e comparar as respostas dos } \\
\text { professores com a informação deste. }\end{array}$ \\
\hline \multirow[t]{4}{*}{17} & 5 & $\begin{array}{l}\text { Esclarecimentos } \\
\text { adicionais }\end{array}$ & A & $\begin{array}{l}\text { Responder perguntas dos professores com relação } \\
\text { ao conteúdo apresentado. }\end{array}$ \\
\hline & Total & Siglas & $E$ & \\
\hline & $120^{\prime}$ & $\mathrm{A}=\mathrm{Apresentador}$ & $E=$ & Etapa \\
\hline & & $\mathrm{P}=$ Professores & $D=$ & Duração \\
\hline
\end{tabular}

Tabela 6- Plano de Apresentação da Oficina 
(Slide 1)

ENSINANDO O FUTURO

Estudar o futuro?

- O objetivo dos estudos do futuro é prever o futuro.

- A velocidade real das mudanças é menor do que imaginamos.

- A maioria das pessoas tem liberdade de escolha.

- Para tomar decisões sobre o futuro, precisamos saber o que irá acontecer.

(Slide 2)

Estudar o futuro?

- O objetivo dos estudos do futuro é melhorar nossa compreensão de uma gama de futuros alternativos.

- Mudanças rápidas são uma das poucas certezas que temos em relação ao presente.

- Liberdade de escolha existe quando compreendemos todas as opções disponíveis e as conseqüências possíveis de cada opção.

- O futuro é uma "zona de potencial": é o conhecimento daquilo é possível.

(Slide 3)

Por que ensinar o futuro?

- "A história humana torna-se cada vez mais uma corrida entre a educação e a catástrofe". H.G Wells

-A mudança é uma das leis da vida. E aqueles que se prendem somente ao passado e ao presente certamente perderão o futuro. John F. Kennedy

Tabela 7- Material utilizado na apresentação da oficina (1.a parte) 


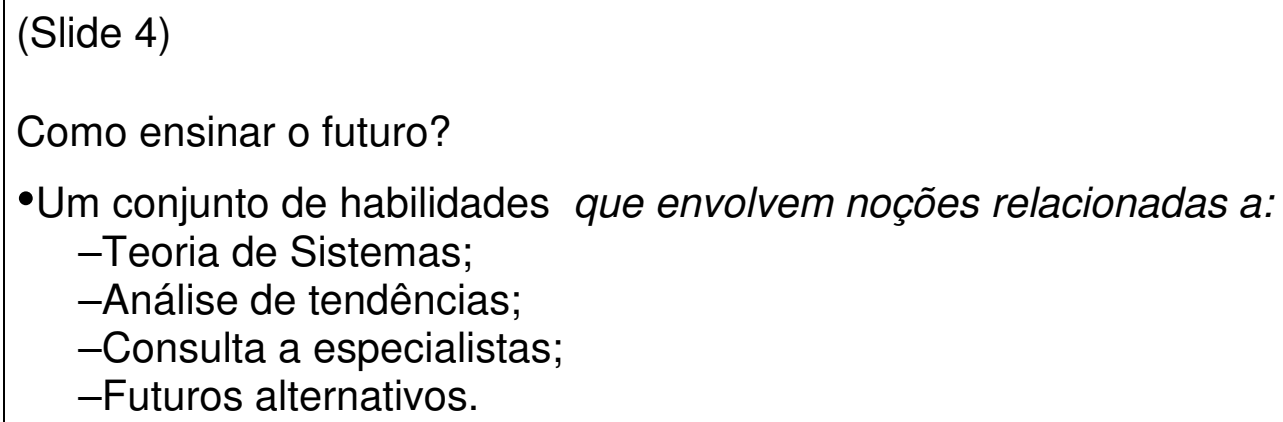

(Slide 5)

Teoria de Sistemas

- "uma coleção organizada de coisas que interagem uma com a outra para funcionar como uma unidade ou um todo"

- Organização $\rightarrow$ interação $\rightarrow$ "todo"

- Sistemas Simples e Complexos

-Simples - A - B

-Sistema complexo A - B- G- E -A

(Slide 6)

Feedback, Estabilidade e Mudança

- Positivo- reforço ou ampliação do comportamento

- Negativo - negação ou reversão do comportamento

-Mudança positiva - crescimento exponencial?

"A solução óbvia para um sistema controlado por feedback negativo raramente terá algum impacto, a não ser piorar o problema".

Tabela 8 - Material utilizado na apresentação da oficina (2.a parte) 
(Slide 7)

Sistemas Complexos

O Fator Humano

-Sistemas Naturais - "reagem"

- Sistemas Humanos:

-Ação $\rightarrow$ Prevenção- "feed-forward".

(Slide 8)

Análise de tendências

- Quais as causas da tendência no passado?

- Qual a probabilidade dessa tendência manter-se estável?

- Quais novos avanços são necessários para que a tendência se mantenha?

- Quais avanços podem alterar essa tendência?

- A tendência beneficia algum grupo (empresa, governo, público) que pode apoiá-la caso ela entre em declínio?

-A tendência tem conseqüências prejudiciais ou efeitos colaterais negativos?

-É provável que medidas sejam tomadas para impedir ou alterar essa tendência?

-A tendência tem conseqüências prejudiciais ou efeitos colaterais negativos?

(Slide 9)

Especialistas

-Referências bibliográficas

-"conservadora"

- Comissões

-"profissionais respeitados nas áreas investigadas"

-"grupos de interesse"

- Pesquisas e questionários

-variedade de opções e origens

Tabela 9 - Material utilizado na apresentação da oficina (3.a parte) 
(Slide 10) Futuros alternativos

- Criação de cenários alternativos

- Análise e combinação das informações

- Agrupamento dos cenários mais distintos entre si

- Redação da "história do futuro"

- Não à armadilha de um "futuro único"

- Possibilidade de testar os planos do presente

\section{(Slide 11)}

Abordagem
Genérica

DESCRIÇÃO

ESTUDOS DO

ASSOCIADOS

PARADIGMAS

MÉTODOS DE

PESQUISA

OBJETIVO
Tipologia dos Estudos do Futuro

PROVÁVEL POSSIVEL DESEJÁVEL

PROSPECTIVo

Análise de tendência - global, ecológica

Imaginação, idéias

Valores

flexibilidade $\quad$ ideológico

Previsão,

Quantitativo A tendência é futuro)

Culturais

Interpretação, Pós-moderno

$\begin{array}{ll}\text { utopias } & \text { ideológico } \\ \text { (vários futuros) } & \text { ("outro" futuro) }\end{array}$

Positivista empírico, analítico

Construtivista,

hermenêutico

Quantitativos

previsão

pesquisas

Qualitativo,

diálogo

colaborativo

visões criativas

Crítico

emancipação

Analise textual

analise de midias,

artefatos culturais

projeção

Abertura de ossibilidades

Consciência

Consitica,
criencia

desconstrução
Ação

autoconfiança

Integração

Transformação

Transformação

("Futurizar")

Mudança de paradigma

transformacional

ativista

Integral

Projeção

planejamento de ação

pesquis

Fortalecimento,

mudança

transformação 
(Slide 12)

\begin{tabular}{|c|c|c|c|}
\hline $\begin{array}{l}\text { QUESTÕES } \\
\text { GLOBAIS }\end{array}$ & ECONOMIA & $\begin{array}{l}\text { POLÍTICA E } \\
\text { GOVERNO }\end{array}$ & $\begin{array}{l}\text { CIÊNCIA E } \\
\text { TECNOLOGIA }\end{array}$ \\
\hline $\begin{array}{l}\text {-guerra e paz } \\
\text {-população e } \\
\text { disponibilidade } \\
\text { de alimentos } \\
\text {-meio ambiente }\end{array}$ & $\begin{array}{l}\text {-“miopia” } \\
\text {-ciclos } \\
\text {-obsolescência } \\
\text { profissional } \\
\text {-desemprego e } \\
\text { previdência } \\
\text {-crescimento }\end{array}$ & $\begin{array}{l}\text {-corrupção dos } \\
\text { canais de } \\
\text { feedback } \\
\text {-dinheiro e } \\
\text { política } \\
\text {-informação } \\
\text { pública } \\
\text {-centralização } \\
\text {-valores e } \\
\text { diversidade }\end{array}$ & $\begin{array}{l}\text {-prós e contras } \\
\text {-energia } \\
\text {-tecnologia- } \\
\text { ambiental } \\
\text {-computação } \\
\text {-engenharia } \\
\text { biológica }\end{array}$ \\
\hline
\end{tabular}

Tabela 10 - Material utilizado na apresentação da oficina (4.a parte)

(Slide 13)

Exemplos de Atividades

- Crenças sobre o futuro.

- Metáforas sobre o futuro

- História improvável

- Ficção-científica

- Criação de comunidades

- Sustentabilidade

(Slide 14)

Estudos do futuro: um projeto

- Detecção de objeto de estudo de importância;

- Investigação (pesquisa) deste tópico durante determinado período;

- Desenvolvimento de conclusões iniciais (análise e raciocínio);

- Discussão das conclusões com especialistas;

- Construção de projeto e apresentação de proposta;

- Persistência, em face à indiferença ou oposição;

- Avaliação dos resultados.

(Slide 15) 
"Psicologia do futuro"

o indivíduo adaptável

- Autonomia;

- Confiança na imagem que faz de si mesmo;

- Não-absolutista;

- "Prevenido e preparado"

- Experimentação (Maslow)

Tabela 11 - Material utilizado na apresentação da oficina (5.a parte) 


\subsection{IDENTIFICANDO AS PERCEPÇÕES DOS PROFESSORES DO ENSINO MÉDIO EM RELAÇÃO AOS ESTUDOS DO FUTURO: INSTRUMENTO DE PESQUISA}

Após a conclusão das duas etapas iniciais, temos então ainda a fase relacionada à coleta de informações relativas à percepção dos professores participantes da oficina de apresentação dos estudos do futuro. A ferramenta escolhida também foi um questionário, mas de caráter mais reduzido, focando os conteúdos apresentados na oficina. Tal questionário usou como modelo a estrutura do questionário utilizado na primeira fase de investigação, tanto por razões de simplicidade e similaridade. Assim como no primeiro questionário, alguns pressupostos guiaram a elaboração das perguntas:

i. os professores participantes teriam um grau de compreensão razoável sobre o que seriam os estudos do futuro e sobre sua relevância ao término da apresentação;

ii. os professores participantes não exibiriam o mesmo grau de compreensão em relação aos diferentes conceitos-chave apresentados e isso influenciaria suas respostas sobre a relevância do aprendizado de tais conceitos-chave por parte dos alunos;

iii. os professores participantes poderiam divergir sobre as habilidades que crêem relevantes para seus alunos e o interesse que estes mesmos alunos poderiam demonstrar em relação ao aprendizado destas;

iv. os professores participantes veriam de modo diverso tanto as questões relativas à introdução de atividades práticas voltadas à criação de um discurso futuro, como ao grau de preparação dos alunos do Ensino Médio em lidar com estas questões. 
No caso do segundo questionário, portanto, as perguntas relativas à vivência dos respondentes como profissionais da educação e suas percepções em relação à capacidade dos jovens para lidar com tais questões tornam-se mais especificas. Mais uma vez, grande parte das perguntas oferecia a oportunidade de respostas numéricas que indicassem o grau de concordância ou discordância em relação às perguntas efetuadas (ver Tabela 12). Discutiremos brevemente agora as diferentes perguntas existentes no questionário:

I- $\quad$ Compreensão da natureza dos estudos do futuro: são oferecidas aqui três opções (pouca, razoável ou boa compreensão) com o intuito de verificar de que maneira a oficina foi bem sucedida em esclarecer a natureza especifica dos estudos do futuro;

II- Relevância dos estudos do futuro: em três categorias diferentes (para o participante em $\mathrm{si}$, seus alunos e a sociedade como um todo) são oferecidas três opções (irrelevantes, pouco relevantes, relativamente relevantes e muito relevantes) com o intuito de verificar se existem discrepâncias nas visões de caráter pessoal, profissional ou coletivo;

III- Apresentação dos conceitos-chave relacionados aos estudos do futuro: mais uma vez são oferecidas aqui três opções (pouca, razoável ou boa compreensão) com o intuito de verificar de que maneira a oficina foi bem sucedida em apresentar os conceitoschave (análise de tendências, teoria de sistemas) planejados;

IV- Benefício do aprendizado destes conceitos-chave: aqui os participantes indicam qual o grau de benefício (alto, médio, baixo) que os jovens obteriam ao aprender os conceitos-chave apresentados;

v- Relevância do aprendizado de habilidades relacionadas aos estudos do futuro: diferentes habilidades mencionadas na tipologia 
apresentada são avaliadas em diferentes graus (irrelevantes, pouco relevantes, relativamente relevantes e muito relevantes) com o intuito de verificar se os professores percebem tais atividades como específicas dos estudos do futuro ou de relevância geral no aprendizado dos jovens;

VI- Interesse no aprendizado de habilidades relacionadas aos estudos do futuro por parte dos alunos: as mesmas habilidades mencionadas na pergunta anterior são avaliadas em termos do interesse que os professores acreditam que os jovens demonstrariam por elas (alto, médio, baixo, nulo) com o intuito de verificar se existem discrepâncias entre aquilo que os professores percebem como relevantes e aquilo que os jovens perceberiam como interessante;

VII- Grau de dificuldade na introdução de atividades práticas relacionadas aos estudos do futuro em sala de aula: são apresentados nove exemplos de atividades práticas (por exemplo, história improvável, ficção cientifica, pesquisa sobre sustentabilidade) para que os respondentes indiquem o que acreditam ser o grau de dificuldade de introdução destas (alto, médio, baixo, nulo) em relação a cada uma delas;

VIII- Grau de preparação dos jovens do Ensino Médio em relação às áreas de interesse relacionadas aos estudos do futuro: são apresentadas as quatro áreas de interesse (como questões globais e economia) para que os respondentes indiquem o que acreditam ser o grau de preparação dos jovens (alto, médio, baixo, nulo) para lidar com cada uma dessas áreas. 


\begin{tabular}{|c|c|c|c|c|}
\hline Sexo & Homem & Mulher & & \\
\hline Idade & -30 & $30-50$ & +50 & \\
\hline Experiência como Educador em anos & $0-5$ & $5-15$ & $15-20$ & +20 \\
\hline Formação & \multicolumn{2}{|c|}{ Graduação Incompleta } & ;ompleta & Pós-graduação \\
\hline
\end{tabular}

I - Em relação à natureza dos 'estudos do futuro', posso dizer que:

\begin{tabular}{|l|l|ll|}
\hline 1- não compreendi bem & 2- tenho uma compreensão razoável & $\begin{array}{l}\text { 3- tenho uma boa } \\
\text { compreensão }\end{array}$ & \\
\hline
\end{tabular}

II- Em relação à relevância dos ‘estudos do futuro' posso dizer que são:
1- irrelevantes
2- pouco relevantes
3- relevantes até certo ponto
4- muito relevantes

para mim para meus alunos para a sociedade como um todo

III- Baseado na apresentação, em relação aos conceitos envolvidos nos estudos do futuro, posso dizer que:

1- não compreendi bem

2- tenho uma compreensão razoável

3- tenho uma boa compreensão

\begin{tabular}{|l|l|l|l|}
\hline análise de tendências & & teoria de sistemas & \\
\hline criação de futuros alternativos & & consulta a especialistas & \\
\hline
\end{tabular}

IV - Baseado na apresentação, em relação ao aprendizado dos conceitos envolvidos nos estudos do futuro, posso dizer que meus alunos:

1- não se beneficiariam muito

2- teriam algum benefício

3- se beneficiariam muito

\begin{tabular}{|l|l|l|}
\hline análise de tendências & & teoria de sistemas \\
\hline criação de futuros alternativos & & consulta a especialistas \\
\hline
\end{tabular}

V- Como vê a relevância do aprendizado das seguintes habilidades por parte dos alunos do ensino médio?
1- muita relevância
2- alguma relevância
3- pouca relevância
4- sem relevância alguma

análise quantitativa de tendências análise textual e de mídia

uso da imaginação na elaboração de cenários planejamento de ações

VI- Como vê o interesse pelo aprendizado das seguintes habilidades por parte dos alunos do ensino médio?
1- muito interesse
2- algum interesse
3- pouco interesse
4- sem interesse algum

\begin{tabular}{|l|l|l|}
\hline análise quantitativa de tendências & & uso da imaginação na elaboração de cenários
\end{tabular}

análise textual e de mídia planejamento de ações

VII- Como julgaria o grau de dificuldade na introdução das seguintes atividades relacionadas aos estudos do futuro junto aos alunos do ensino médio?
1- muito difícil
2- um pouco difícil
3- não muito difícil
4- fácil

\begin{tabular}{|l|l|l|}
\hline crenças sobre o futuro & metáforas sobre o futuro & \\
\hline história improvável & ficção científica & \\
\hline criação de comunidade & pesquisas sobre sustentabilidade \\
\hline
\end{tabular}

VIII- Na sua opinião, qual o grau de preparação dos alunos do ensino médio para lidar com as seguintes áreas de interesse relacionadas aos estudos do futuro?
1- alto
2- médio
3- baixo
4- sem preparação

\begin{tabular}{|l|l|l|l|}
\hline questões globais & & política e governo & \\
\hline economia & & ciência e tecnologia & \\
\hline
\end{tabular}

Tabela 12- Questionário usado na 2.a fase da investigação 


\subsection{ACOMPANHANDO A IMPLEMENTAÇÃO DE PROJETOS ENVOLVENDO OS ESTUDOS DO FUTURO NAS ESCOLAS: COLETA DE DADOS}

A última fase sugerida como parte da pesquisa é também a mais difícil de ser avaliada com ferramentas específicas, devido à natureza diversificada dos experimentos que porventura venham a ser realizados. De fato, caso as escolas adotem a abordagem ou uso de algumas das ferramentas sugeridas na oficina, seus usos poderão ser muito diversos tanto em quantidade como no tempo em que foram empregadas. Ainda, a avaliação dos experimentos realizados deve considerar que um experimento no uso dessa abordagem, baseado em um processo de inovação curricular, não deveria necessariamente julgar somente a qualidade no uso da abordagem ou ferramenta em si, mas sim o grau de facilidade e eficácia em sua implementação.

Não poderíamos naturalmente esperar que após uma breve sessão de familiarização os professores se acreditassem plenamente capazes no uso da abordagem e das ferramentas. Assim, nos interessaria inicialmente o quão ágil foi a implementação de tais ferramentas e não necessariamente se elas foram usadas com a segurança e a cautela usada pelos profissionais da área. Em outras palavras, o bom ou mau uso da ferramenta teria inicialmente mais a dizer sobre as condições de quem as utiliza do que sobre a ferramenta em si e, no nosso caso, apontaria para áreas específicas de treinamento subseqüente no uso da ferramenta. Assim, o uso incipiente das ferramentas dos estudos do futuro não necessariamente as inviabiliza como ferramentas e sim indicam o tipo de trabalho a ser realizado para uma implementação bem sucedida.

Dada essa natureza diversificada de experimentação (e, certamente, das possíveis condições dos estabelecimentos para a execução de tais experimentos), optamos por oferecer uma série de alternativas para 0 acompanhamento dos projetos a ser implementados:

i. Encontros subseqüentes com os coordenadores das escolas para discussão de abordagens visando a implementação dos estudos do 
futuro nas escolas;

ii. Encontros subseqüentes com grupos de professores envolvidos nos projetos para melhor esclarecimento de determinadas ferramentas e ou planejamento de ações;

iii. Seleção de material de leitura relacionado aos estudos do futuro para ampliar o referencial teórico/ prático dos professores;

iv. Auxílio na adaptação de materiais a ser utilizados na implementação de projetos;

v. Auxílio na criação de materiais a ser usados para avaliar a implementação de projetos;

Acreditamos, dessa forma, atender à diferentes necessidades que poderão surgir durante a implementação de projetos. Naturalmente, para efeito de análise posterior, o processo de acompanhamento envolverá a coleta de informações relativas ao número de experimentos realizados em cada uma das instituições, o escopo dos experimentos realizados, exemplos de atividades utilizadas, opiniões e reflexões a respeito dos experimentos e atividades por parte dos educadores e dos jovens envolvidos. 


\section{DESCRIÇÃO DA INVESTIGAÇÃO E RESULTADOS}

\subsection{CONTATO COM DIFERENTES ESTABELECIMENTOS DE ENSINO MÉDIO DA CIDADE DE SÃO PAULO}

Para obtermos uma amostragem com uma composição demográfica relevante, considerando-se a população dos professores de Ensino Médio de São Paulo, foram contatadas quatro escolas da rede pública e três escolas da rede particular no município de São Paulo, de onde foram extraídas 200 respostas.

No caso do primeiro grupo, o contato inicial mostrou-se lento, e somente depois de diversas tentativas em todos os casos, foi possível obter maiores informações e organizar um encontro para a apresentação do projeto. Apesar do interesse inicial demonstrado após a apresentação do projeto, uma das escolas recusou a pesquisa sob a alegação de que outras pesquisas já estavam em realização na instituição e de que os professores já estariam sobrecarregados pelo excesso de atividades no ano letivo. As outras duas escolas aceitaram participar da pesquisa inicial, ressaltando que a realização das outras etapas seria, a princípio, difícil, devido também ao excesso de atividades dos professores. Estas escolas são a Escola de Ensino Fundamental e Médio Professor Derville Alegretti (com 3000 alunos e cerca de 100 professores) e a Escola Estadual de Segundo Grau Albino César (com 2600 alunos e 100 professores). Com o intuito de manter o equilíbrio da composição demográfica da amostra entre o número de grupos de profissionais atuantes nas diferentes redes de ensino, um terceiro grupo foi formado por cerca de 25 alunos do último ano do curso de Licenciatura em Letras da Universidade Bandeirante de São Paulo, que já atuam como professores eventuais ou efetivos de ensino fundamental e médio em escolas da rede pública de São Paulo ou em municípios da periferia de São Paulo. 
As comunicações e o interesse inicial pelo projeto mostraram-se mais ágeis nas escolas da rede particular contatadas para o projeto. Em todos os casos, a coordenação sugeriu que, caso a pesquisa inicial tivesse boa receptividade por parte dos professores, seria possível o agendamento da sessão de familiarização sobre os estudos do futuro, ainda que não houvesse garantia imediata de que algum projeto dessa natureza fosse colocado em prática. As escolas particulares que aceitaram participar da pesquisa foram o Colégio Bandeirantes (com cerca de 30 professores de Ensino Médio), o Colégio I. L. Peretz, (com cerca de 70 professores de Ensino Fundamental e Médio) e o Colégio Sidarta (com cerca de 30 professores de Ensino Médio).

A dificuldade de acesso a algumas das escolas, principalmente as da rede pública parece nos remeter às observações feitas anteriormente em relação à escola como "representante" de um sistema focado em si mesmo e com tendência ao isolamento e resistente a tentativas de mudança. Por outro lado, mostra também uma atitude de proteção em relação ao trabalho de seus profissionais, de modo a permitir que poucos elementos externos possam interferir em suas práticas educativas.

Fizemos uma opção consciente por um número relativamente maior de respondentes oriundos das escolas da rede pública na fase inicial da investigação por duas razões: a maior parte dos alunos freqüenta esses estabelecimentos e, devido às dificuldades encontradas nos contatos iniciais, nos pareceu que quanto maior o número de respondentes naquele setor, maiores seriam as chances de que pelo menos alguns destes adotassem a abordagem proposta. Além desse fato, quaisquer características de implementação de uma abordagem relacionada aos estudos do futuro que viessem a ocorrer nesse setor seriam de grande interesse para o pesquisador. Em contra partida, os diferentes projetos educacionais levados a cabo pelos estabelecimentos da rede particular por um lado poderiam propiciar uma maior agilidade na implementação de tal abordagem. Ainda que de grande interesse para esta pesquisa, seria importante ressaltar as diferentes condições de trabalho vivenciadas pelos profissionais 
dessas escolas. Mesmo que isso não se constitua um detrimento da qualidade dos projetos porventura a serem realizados em ambas as redes (uma vez que a flexibilidade no uso das ferramentas seria uma condição essencial para a realização dos projetos), fazia-se necessário uma distinção de forma a equiparar proporcionalmente as duas populações. De qualquer forma, a estratificação da amostra (professores atuantes no Ensino Médio) torna-se bastante evidente.

\subsection{DISTRIBUIÇÃO DE QUESTIONÁRIOS E COLETA DE DADOS}

Em seguida aos contatos iniciais para apresentação do projeto os questionários foram entregues de acordo com os números de respondentes possíveis sugerido pelas coordenadorias ou direções dessas escolas. Estas, por sua vez, se encarregariam da distribuição e coleta destes junto aos professores para que fossem retirados posteriormente. Mais uma vez, a premissa era a de que a pesquisa fosse realizada com o menor grau de interferência possível por parte do pesquisador. O processo de distribuição e coleta dos questionários da primeira fase ocorreu entre março e meados de junho de 2007.

Devido à extensão do questionário e da diversidade de respostas a serem analisadas, tomamos a decisão de considerar apenas os questionários respondidos por completo em nossa análise. No caso da Escola Albino César, os 60 questionários requisitados seriam, segundo a direção, provavelmente respondidos durante o período de hora-atividade e planejamento no qual os professores permanecem na escola. Desse total, 45 questionários foram devolvidos, sendo que 3 deles estavam com diversas respostas incompletas e portanto, foram desconsiderados. No caso da Escola Derville Alegretti, dos 70 questionários enviados apenas 52 foram devolvidos, sendo que dentre estes, somente 48 estavam respondidos por completo. Entre os alunos da UNIBAN o total de questionários preenchidos por completo chegou a 26. No caso das 
escolas particulares, estas mesmas se ofereceram para a reprodução e distribuição do questionário junto aos professores: a escola particular com 0 maior número de questionários considerados foi o colégio I. L. Peretz (51), tanto o Colégio Bandeirantes como o Colégio Sidarta devolveram um total de 17 questionários corretamente preenchidos cada, totalizando um número de 34 questionários (ver Tabela 13).

No caso das escolas da rede pública, o retorno de questionários (parcial ou completamente respondidos) inferior ao número requisitado pela própria coordenação ou direção já havia sido aventado, pelo fato de que a direção não poderia oferecer garantia alguma que os professores respondessem tal questionário, já que isso não era uma de suas atribuições. De qualquer forma, a coordenação das escolas, em sua grande maioria, demonstrou interesse nos resultados do questionário quando de sua coleta pelo pesquisador. Passemos agora a discussão do instrumento de pesquisa e metodologia e à apresentação dos resultados da primeira fase.

\subsubsection{RESULTADOS DO 1 QUESTIONÁRIO}

Como o modelo de questionário utilizado na primeira fase é baseado em um questionário já utilizado em outra pesquisa, procuramos adotar os mesmos princípios relativos à avaliação dos resultados, de forma que esta pesquisa apresentasse resultados que pudessem ser comparados aos de outras populações já analisadas.

A abordagem utilizada nesta investigação, ao mesmo tempo em que eficiente em termos de custo e tempo, merece algumas observações. Em primeiro lugar, a pesquisa limitou-se às escolas cuja coordenação ou direção aceitaram fazer parte da investigação. Dessa maneira, o acesso aos professores (no nosso caso, os agentes principais relacionados à implementação de 
inovações curriculares) foi ou facilitado ou encorajado por um "nível hierárquico" acima, apesar da proposta em momento algum sugerir a imposição das etapas usadas na investigação. Tal processo de filtragem (que também irá se aplicar aos questionários da segunda fase da investigação, por exemplo), indica uma amostragem de caráter reduzido em relação ao total da população de professores.

Devido a essas razões, utilizamos uma amostragem aleatória estratificada, de natureza não proporcional. Para um coeficiente de confiança de $95 \%$ na interpretação das médias relacionadas a respostas qualitativas, a margem de erro adotada foi de 0,13 . Para o mesmo coeficiente de confiança em respostas envolvendo porcentagens, o coeficiente de confiança adotado foi de $6 \% \mathrm{em}$ relação aos valores levantados. (Gil: 1999). Ainda assim, os dados serão interpretados primeiramente com base nas variações encontradas em cada um dos estratos e como essas variações demonstram semelhança ou diferença em relação às variações dos outros estratos e não necessariamente através da comparação de cada um dos sub-estratos.

Em segundo lugar, apesar da amostragem ser o mais randômica possível dentro dos estratos investigados, não podemos afirmar que $\mathrm{X} \%$ da população dos professores da cidade de São Paulo, por exemplo, tem uma determinada percepção da palavra "futuro". Mesmo que a composição de nossa amostra reflita a proporção encontrada no Censo de 2000 relativa ao número de profissionais do sexo masculino e feminino, por exemplo, podemos somente afirmar qual porcentagem de nossa amostra partilha de determinadas percepções (IBGE, 2007). Entretanto, acreditamos ser importante revelar a outros estudiosos do futuro quais seriam essas percepções, em primeiro lugar, para que existissem dados de natureza qualitativa que pudessem pelo menos orientar pesquisas futuras. 
Por fim, como a composição de nossa amostra concentra-se em professores da cidade de São Paulo, podemos também perceber que tais professores geralmente apresentam uma possibilidade maior de acesso a recursos do que professores de cidades de pequeno e médio porte do interior do estado, por exemplo. Esperamos que pesquisas futuras incluam uma maior variedade de perfis demográficos em suas respostas.

\subsubsection{RESPONDENTES}

Duzentos indivíduos completaram a primeira fase da pesquisa. A Tabela 13 apresenta a distribuição de respondentes de acordo com suas instituições de origem. O grupo predominante na amostra foi o dos professores que atuam em escolas da rede pública (58\%), com o restante $(42 \%)$ oriundo de estabelecimentos do setor privado.

A Tabela 14 apresenta as características demográficas dos respondentes. Como a metodologia de amostragem usada nesse estudo foi de natureza randômica e pelo fato deste estudo limitar-se a professores de Ensino Médio, esperávamos que os resultados fossem diversos em alguns aspectos e bastante semelhantes em outros. O resultado confirmou o pressuposto de que a maior parte dos profissionais nesse setor ainda é do sexo feminino (66\%). Como esperado também, a faixa etária dos 30-50 anos de idade tem maior representação nesse estudo (51\%), seguida pela faixa dos respondentes com menos de 30 anos de idade (31\%) e por fim, dos respondentes com mais de 50 anos de idade (18\%). Acreditamos, assim, que a amostra contém números significativos dos três grupos, no sentido de avaliar se diferentes idades apresentam diferentes percepções de "futuro". Outros aspectos da amostra podem não ser tão representativos da população de professores do Ensino Médio da cidade São Paulo: em nossa amostra a maior parte dos respondentes (38,5\%) está na fase inicial de suas carreiras ( 0 a 5 anos de experiência); os grupos que 
possuem entre 5 e 15 anos e entre 15 e 20 anos de experiência profissional encontram-se representados de maneira bastante semelhante $(21,5 \%$ e $21 \%$ respectivamente); e o menor grupo (19\%) concentra os profissionais com mais de 20 anos de experiência. 
Tabela 13. Distribuição por Instituição

\begin{tabular}{|l|c|c|}
\hline & Homens & Mulheres \\
\hline Colégio Albino César & 13 & 29 \\
\hline Colégio Bandeirantes & 4 & 13 \\
\hline Colégio Derville Alegreti & 19 & 29 \\
\hline Colégio L. Peretz & 15 & 36 \\
\hline Colégio Sidarta & 7 & 10 \\
\hline UNIBAN & 10 & 16 \\
\hline & $33 \%$ & $66 \%$ \\
\hline
\end{tabular}

(Número de Respondentes) 
Tabela 14 . Distribuição Demográfica

\begin{tabular}{|l|c|c|c|c|c|}
\hline Sexo & & & & & Totais \\
\hline Masculino & 68 & & & & 200 \\
\hline Feminino & 132 & & & & \\
\hline Idade & $<30$ & $30-50$ & $>50$ & & \\
\hline Homens & 20 & 40 & 8 & & 200 \\
\hline Mulheres & 42 & 62 & 28 & & \\
\hline $\begin{array}{l}\text { Experiência como } \\
\text { Educador em anos }\end{array}$ & $\mathbf{0 - 5}$ & $5-15$ & $15-20$ & +20 & \\
\hline Homens & 30 & 16 & 14 & 7 & 200 \\
\hline Mulheres & 47 & 27 & 28 & 31 & \\
\hline Formação & $\begin{array}{c}\text { Graduação } \\
\text { Incompleta }\end{array}$ & $\begin{array}{c}\text { Graduação } \\
\text { Completa }\end{array}$ & $\begin{array}{c}\text { gós- } \\
\text { graduação }\end{array}$ & & \\
\hline Homens & 21 & 32 & 15 & & 200 \\
\hline Mulheres & 42 & 60 & 30 & & \\
\hline Religião & Católica & Judaica & Evangélica & Outras & \\
\hline Homens & 32 & 20 & 12 & 4 & 200 \\
\hline Mulheres & 38 & 30 & 8 & \\
\hline
\end{tabular}

(Número de Respondentes) 
Apesar de incluídos no questionário, os dados referentes à experiência dos professores não serão comparados nessa primeira fase: eles foram coletados para que pudéssemos compará-los com os resultados da segunda fase da investigação, que é mais voltado à adoção de abordagens relacionadas ao ensino do futuro em sala de aula (e onde a questão da experiência profissional seria mais relevante na análise). Todavia, foram incluídos no primeiro questionário para indicar a diversidade de perfis dos respondentes da amostra original.

No entanto, analisaremos a variável relacionada à formação dos professores, no intuito de verificar de que forma um maior grau de formação pode influenciar percepções e atitudes. Nesse caso, a distribuição encontrada também já era de certa forma esperada: a maioria (46\%) é graduada. No caso de nossa amostra, no entanto, o segundo grupo mais relevante não é o de professores com pós-graduação (apenas $23,5 \%$ ), mas sim o de professores cuja graduação universitária é incompleta $(31,5 \%)$. Isso se explica pelo uso de um dos grupos da amostra (professores já atuantes que buscam certificação).

Os respondentes também indicaram uma diversidade de crenças religiosas, embora a maior parte deles afirma ser católica (44\%); seguida pelos professores de fé judaica (29\%) e os professores evangélicos (21\%), aqui reunindo membros de igrejas protestantes e batistas, por exemplo. Outras religiões (budismo, espiritismo, por exemplo) são pouco representadas na amostra (6\%). Os resultados a seguir foram analisados em relação aos estratos demográficos incluídas na amostra e suas variações. 


\subsubsection{DISCUSSÃO DOS RESULTADOS DO 1ํQUSTIONÁRIO}

Confirmando um dos pressupostos usados na elaboração do questionário, as interpretações dos professores da palavra "futuro" podem ser descritas como muito mais próximas do presente do que o contrário, apesar de não termos inicialmente expectativa alguma de quão próximas tais interpretações seriam. Mais da metade deles (61\%) pensa em futuro em termos de 30 anos ou menos. Menos da metade destes (23,5\%) pensam em futuro como algo entre 30-50 anos do presente e menos respondentes ainda (15,5\%) pensam em futuro como um período daqui a 50 anos ou mais.

A Tabela 15 indica que, na média, os professores respondentes interpretam o futuro como um ponto a aproximadamente 15 anos do presente, com uma mediana de apenas 10 anos desse presente. Não deixa de ser surpreendente como a média e a mediana estão próximas em relação ao presente, especialmente se considerarmos o papel de preparação de jovens para o futuro geralmente associado com as funções do professorado. Os profissionais dos estudos do futuro normalmente interpretariam a palavra futuro em um contexto de maior prazo, digamos de 50 a 100 anos, se não mais. Uma conclusão possível sugeriria que as pessoas interpretam tal palavra em relação às suas próprias vidas e experiências e não em respeito a questões públicas de maiores dimensões.

Há uma diferença significante entre como a palavra 'futuro' é interpretada por homens e mulheres. As mulheres tendem a interpretar a palavra como algo mais próximo ao presente do que os homens e mostram menos variação em sua interpretação da palavra. Existem também variações entre as diferentes faixas etárias e diferenças crenças, mas estas não foram estatisticamente significantes. Os mais jovens e os mais velhos tendem a também interpretar a palavra como mais perto do tempo presente do que aqueles de meia-idade, embora os mais jovens demonstrem maior variação em suas respostas especialmente se 
compararmos essas respostas à pouca variação destas entre os mais velhos. Os professores católicos, por fim, interpretam a palavra em seu menor período de tempo em relação a outras religiões. 
Tabela 15. "Ao ouvir a palavra 'futuro', você pensa aproximadamente em... ?"

\begin{tabular}{|l|c|c|c|}
\hline & Média & Mediana & Desvio Padrão. \\
\hline $\begin{array}{l}\text { Todos os } \\
\text { Respondentes }\end{array}$ & 14.79 & 10.0 & 21.3 \\
\hline Homens & 16.8 & 10.0 & 26.2 \\
\hline Mulheres & 13.0 & 10.0 & 14.4 \\
\hline & & & \\
\hline$<30$ Anos & 14.2 & 10.0 & 24.3 \\
\hline 30-50 Anos & 15.7 & 10.0 & 22.1 \\
\hline$>50$ Anos & 14.0 & 10.0 & 15.8 \\
\hline & & & \\
\hline Católica & 13.00 & 10.0 & 15.9 \\
\hline Judaica & 21.8 & 10.0 & 26.4 \\
\hline Evangélica & 22.0 & 10.0 & 43.6 \\
\hline Outras & 17.1 & 10.0 & 35.4 \\
\hline
\end{tabular}

(Número de Anos no Futuro) 
Dessa forma, também esperávamos que os professores pensassem com mais freqüência em períodos futuros mais próximos do que aqueles mais distantes do presente. Os resultados da Tabela 16 parecem corroborar nossas expectativas. De forma geral, os respondentes tendem a pensar com maior freqüência períodos futuros daqui uma semana, um mês e um ano. Tais reflexões sobre o futuro tendem a se degradar até o ponto dos respondentes afirmarem que não pensam freqüentemente em futuros em períodos de tempo de mais do que 20 anos. As médias das respostas é significantemente diferente considerando-se os seis períodos de tempo apresentados. Tais resultados são consistentes com os resultados da Tabela 15, no sentido de que metade da amostra não interpreta a palavra "futuro" como um tempo mais do que a 10 anos do presente.

Os respondentes do grupo de menor faixa etária, por sua vez, parecem pensar mais no futuro imediato do que os do grupo de maior faixa etária. Estes últimos, de forma já esperada, pensam menos em suas vidas em períodos futuros a mais de 20 anos do presente. Poucas diferenças foram notadas em termos de sexo e religião, embora os resultados sugiram que os professores católicos sejam o grupo com a percepção mais imediata de futuro em relação a outras religiões. Diferenças marcantes entre os respondentes de diferente formação tampouco foram notadas, com uma tendência daqueles com menor formação e com maior formação a pensarem mais freqüentemente no futuro, e em diferentes períodos de tempo. 
Tabela 16. "Com que freqüência você pensa em como sua vida será daqui...?"

\begin{tabular}{|c|c|c|c|c|c|c|}
\hline & $\begin{array}{c}\text { uma } \\
\text { semana }\end{array}$ & $\begin{array}{l}\text { um } \\
\text { mês }\end{array}$ & $\begin{array}{l}\text { um } \\
\text { ano }\end{array}$ & $\begin{array}{c}\text { dez } \\
\text { anos }\end{array}$ & $\begin{array}{l}\text { vinte } \\
\text { anos }\end{array}$ & $\begin{array}{c}\text { mais do } \\
\text { que } 20 \\
\text { anos }\end{array}$ \\
\hline $\begin{array}{l}\text { Média } \\
\text { Geral }\end{array}$ & 1,88 & 1,85 & 1,78 & 2,02 & 2,34 & 2,57 \\
\hline Homens & 1,76 & 1,82 & 1,97 & 2 & 2,31 & 2,56 \\
\hline Mulheres & 1,94 & 1,87 & 1,69 & 2,03 & 2,35 & 2,57 \\
\hline $\begin{array}{l}\text { Graduação } \\
\text { Completa }\end{array}$ & 1,89 & 1,80 & 1,89 & 2,11 & 2,39 & 2,64 \\
\hline $\begin{array}{l}\text { Graduação } \\
\text { Incompleta }\end{array}$ & 1,79 & 1,82 & 1,61 & 1,98 & 2,29 & 2,54 \\
\hline $\begin{array}{l}\text { Pós } \\
\text { Graduação }\end{array}$ & 1,95 & 1,95 & 1,77 & 1,84 & 2,26 & 2,44 \\
\hline$<30$ Anos & 1,81 & 1,8 & 1,77 & 1,98 & 2,31 & 2,55 \\
\hline $\begin{array}{l}30-50 \\
\text { Anos }\end{array}$ & 1,87 & 1,86 & 1,77 & 2,07 & 2,43 & 2,63 \\
\hline$>50$ Anos & 2,08 & 1,91 & 1,88 & 1,97 & 2,14 & 2,44 \\
\hline Católica & 1,91 & 1,88 & 1,57 & 1,91 & 2,33 & 2,53 \\
\hline Judaica & 2,09 & 1,91 & 1,73 & 2,15 & 2,36 & 2,58 \\
\hline Evangélica & 1,42 & 1,42 & 1,42 & 1,92 & 2,67 & 2,83 \\
\hline Outras & 1,84 & 1,78 & 1,82 & 2,02 & 2,31 & 1,84 \\
\hline
\end{tabular}

\begin{tabular}{|c|c|c|c|}
\hline $\begin{array}{c}\text { 1-com muita } \\
\text { freqüência }\end{array}$ & $\begin{array}{c}\text { 2- com alguma } \\
\text { freqüência }\end{array}$ & $\begin{array}{c}\text { 3-com pouca } \\
\text { freqüência }\end{array}$ & 4- nunca \\
\hline
\end{tabular}


Esperávamos que as pessoas se preocupassem com períodos futuros mais próximos ao presente do que aqueles mais distantes. Os resultados da Tabela 17 são de certa forma, contrários a estas expectativas. De forma geral, os professores são menos preocupados com o futuro daqui a uma semana ou mês do que com o futuro daqui a 1 ou 10 anos. Tais resultados parecem sugerir que as pessoas acreditam exercer algum tipo de controle sobre suas vidas a curto prazo e, portanto, se preocupem menos com o futuro mais próximo. À medida que 0 horizonte delas avista períodos mais distantes, parece existir mais incerteza, e dessa forma, mais preocupação. Também em termos gerais, a amostra demonstra um certo grau de preocupação permanente com o futuro, já que a média de nenhum dos resultados, mesmo para períodos futuros daqui a 20 anos ou mais nunca se aproxima da categoria "não me preocupo muito".

As mulheres parecem se preocupar mais com o futuro do que os homens, particularmente com os períodos onde a maioria das respostas já demonstrava um maior grau de preocupação. Os indivíduos mais jovens demonstram grau de preocupação semelhante. Mais uma vez, os professores católicos apresentam uma tendência a se preocuparem mais com o futuro do que os professores de outras religiões. Em termos de formação acadêmica, as diferenças encontradas na resposta anterior permaneceram, ou seja, as preocupações parecem ser maiores entre os mais jovens e os mais velhos. 
Tabela 17. "Qual seu grau de preocupação com sua vida daqui a...?"

\begin{tabular}{|l|c|c|c|c|c|c|}
\hline & $\begin{array}{c}\text { uma } \\
\text { semana }\end{array}$ & um mês & $\begin{array}{c}\text { um } \\
\text { ano }\end{array}$ & $\begin{array}{c}\text { dez } \\
\text { anos }\end{array}$ & $\begin{array}{c}\text { vinte } \\
\text { anos }\end{array}$ & $\begin{array}{c}\text { mais do } \\
\text { que 20 } \\
\text { anos }\end{array}$ \\
\hline Média Geral & 2,24 & 2,24 & 1,82 & 2,02 & 2,04 & 2,40 \\
\hline Homens & 2,54 & 2,54 & 2,00 & 2,21 & 2,25 & 2,43 \\
\hline Mulheres & 2,18 & 2,14 & 1,89 & 1,89 & 1,96 & 2,36 \\
\hline & & & & & & \\
\hline$<30$ Anos & 2,15 & 2,19 & 1,89 & 1,89 & 2,00 & 2,07 \\
\hline $30-50$ Anos & 2,29 & 2,12 & 1,82 & 1,94 & 1,94 & 2,35 \\
\hline$>50$ Anos & 2,29 & 2,15 & 2,12 & 1,97 & 2,00 & 2,26 \\
\hline & & & & & & \\
\hline $\begin{array}{l}\text { Graduação } \\
\text { Completa }\end{array}$ & 1,88 & 1,78 & 1,87 & 2,09 & 2,37 & 2,63 \\
\hline $\begin{array}{l}\text { Graduação } \\
\text { Incompleta }\end{array}$ & 1,77 & 1,80 & 1,65 & 1,94 & 2,27 & 2,53 \\
\hline $\begin{array}{l}\text { Pós } \\
\text { Graduação }\end{array}$ & 1,98 & 1,94 & 1,74 & 1,83 & 2,24 & 2,46 \\
\hline & 2,07 & 1,96 & 1,67 & 1,78 & 1,81 & 2,41 \\
\hline Católica & 2,07 & 2,21 & 2,09 & 1,91 & 2,26 & 2,21 \\
\hline Judaica & 2,32 & 2,21 & 1,90 & 2,00 & 2,06 & 2,29 \\
\hline Evangélica & 2,31 & 2,23 & 2,00 & 2,15 & 2,46 & 2,46 \\
\hline Outras & 2,24 & 2,22 & & & & \\
\hline
\end{tabular}

\begin{tabular}{|c|c|c|c|}
\hline $\begin{array}{c}\text { 1- me preocupo } \\
\text { muito }\end{array}$ & $\begin{array}{c}\text { 2- me preocupo } \\
\text { um pouco }\end{array}$ & $\begin{array}{c}\text { 3- não me preocupo } \\
\text { muito }\end{array}$ & $\begin{array}{c}\text { 4- não me } \\
\text { preocupo }\end{array}$ \\
\hline
\end{tabular}


Esperávamos também que a capacidade dos respondentes em visualizar o futuro com clareza iria diminuir perceptivelmente em determinado ponto no futuro, mas não desenvolvemos expectativas em relação a qual esse ponto seria. Os resultados da Tabela 18 sugerem realmente que a habilidade dos professores em visualizar o futuro diminui à medida que esse período de tempo avança. Existe uma contínua e representativa degradação dessa visão já a partir dos períodos relacionados a 1 ano e entre 1 a 2 anos a partir do presente (com as respostas se aproximando mais de "alguma clareza" do que "muita clareza"), que se acentua nos períodos de 2-5 anos ("alguma clareza"), 5-10 anos (indo de "alguma clareza" para "pouca clareza") e, a partir do período de 10-20 anos ("pouca clareza") acentuando-se cada vez mais. Os resultados sugerem que, para a maior parte dos professores, o futuro torna-se "obscuro" a partir de 20 anos do presente. É interessante notar que esse padrão não apresenta diferenças perceptíveis em quaisquer das categorias demográficas, embora as diferenças já percebidas em relação ao sexo e à religião permaneçam. 
Tabela 18. "Com que clareza consegue visualizar o futuro daqui a... ?"

\begin{tabular}{|c|c|c|c|c|c|c|c|c|c|c|}
\hline & 1 ano & $\begin{array}{c}1-2 \\
\text { Anos }\end{array}$ & $\begin{array}{c}2-5 \\
\text { Anos }\end{array}$ & $\begin{array}{l}5-10 \\
\text { Anos }\end{array}$ & $\begin{array}{l}10-20 \\
\text { Anos }\end{array}$ & $\begin{array}{c}20-50 \\
\text { Anos }\end{array}$ & $\begin{array}{c}50- \\
100 \\
\text { Anos }\end{array}$ & $\begin{array}{l}100- \\
200 \\
\text { Anos }\end{array}$ & $\begin{array}{l}200- \\
1000 \\
\text { Anos }\end{array}$ & $\begin{array}{c}\text { Mais } \\
\text { de } \\
1000 \\
\text { Anos }\end{array}$ \\
\hline Média Geral & 1,72 & 1,85 & 2,10 & 2,42 & 2,70 & 3,04 & 3,40 & 3,58 & 3,62 & 3,61 \\
\hline Homens & 1,70 & 1,81 & 2,07 & 2,45 & 2,82 & 3,12 & 3,54 & 3,64 & 3,66 & 3,63 \\
\hline Mulheres & 1,73 & 1,87 & 2,11 & 2,40 & 2,64 & 3,00 & 3,33 & 3,54 & 3,59 & 3,59 \\
\hline$<30$ Anos & 1,75 & 1,80 & 2,10 & 2,38 & 2,67 & 3,02 & 3,49 & 3,54 & 3,59 & 3,62 \\
\hline 30-50 Anos & 1,67 & 1,82 & 2,05 & 2,42 & 2,74 & 3,11 & 3,44 & 3,69 & 3,73 & 3,69 \\
\hline$>50$ Anos & 1,82 & 2,06 & 2,26 & 2,47 & 2,62 & 2,82 & 3,09 & 3,26 & 3,29 & 3,29 \\
\hline $\begin{array}{l}\text { Graduação } \\
\text { Completa }\end{array}$ & 1,71 & 1,87 & 2,13 & 2,42 & 2,69 & 3,07 & 3,36 & 3,58 & 3,62 & 3,60 \\
\hline $\begin{array}{l}\text { Graduação } \\
\text { Incompleta }\end{array}$ & 1,68 & 1,77 & 2,03 & 2,39 & 2,71 & 3,05 & 3,53 & 3,61 & 3,66 & 3,68 \\
\hline $\begin{array}{l}\text { Pós } \\
\text { Graduação }\end{array}$ & 1,80 & 1,93 & 2,16 & 2,47 & 2,73 & 3,02 & 3,33 & 3,56 & 3,58 & 3,56 \\
\hline Católica & 1,81 & 1,95 & 2,15 & 2,38 & 2,67 & 3,00 & 3,32 & 3,62 & 3,59 & 3,56 \\
\hline Judaica & 1,62 & 1,85 & 2,21 & 2,65 & 2,94 & 3,35 & 3,68 & 3,76 & 3,76 & 3,74 \\
\hline Evangélica & 1,54 & 1,77 & 1,92 & 2,38 & 2,69 & 3,08 & 3,38 & 3,54 & 3,62 & 3,62 \\
\hline Outras & 1,73 & 1,79 & 2,04 & 2,36 & 2,61 & 2,97 & 3,39 & 3,47 & 3,60 & 3,61 \\
\hline
\end{tabular}

\begin{tabular}{|c|c|c|c|}
\hline $\begin{array}{c}\text { 1- muita } \\
\text { clareza }\end{array}$ & $\begin{array}{c}\text { 2- alguma } \\
\text { clareza }\end{array}$ & $\begin{array}{c}\text { 3- pouca } \\
\text { clareza }\end{array}$ & $\begin{array}{c}\text { 4- sem clareza } \\
\text { alguma }\end{array}$ \\
\hline
\end{tabular}


Outra de nossas expectativas era relacionada à natureza ou otimista ou pessimista dos respondentes. A Tabela 19 sugere que, em geral, as pessoas são otimistas, principalmente nos períodos futuros de curto prazo. Tal otimismo parece, no entanto, gradualmente se dissipar à medida que os períodos de tempo aumentam. As mulheres, apesar de se preocuparem e pensarem com maior freqüência no futuro, tendem a ser mais otimistas que os homens, sendo que somente em termos de futuro distante (200 anos ou mais à frente) é que as percepções se assemelham. Os indivíduos mais velhos em geral são menos otimistas em relação ao futuro de médio prazo que os outros. confirmando nossas expectativas, os indivíduos com menos de 30 anos são geralmente otimistas em relação ao futuro. Aqueles com formação incompleta também parecem demonstrar um grau perceptivelmente maior de otimismo em relação aos indivíduos de maior formação, o que talvez indique maior esperança em termos de mudanças com o futuro a porvir para essa faixa. Em termos de religião, os resultados mostram que os professores evangélicos e membros de outras religiões tendem a ser mais otimistas em relação ao futuro do que os professores católicos e judeus, sugerindo que o grau de preocupação demonstrado anteriormente afete inversamente o grau de otimismo em relação ao futuro para estes grupos. 
Tabela 19. "Como se sente com relação ao futuro daqui a ... ?"

\begin{tabular}{|c|c|c|c|c|c|c|c|c|c|c|}
\hline & 1 ano & $\begin{array}{l}1-2 \\
\text { Anos }\end{array}$ & $\begin{array}{l}2-5 \\
\text { Anos }\end{array}$ & $\begin{array}{l}5-10 \\
\text { Anos } \\
\end{array}$ & $\begin{array}{l}10-20 \\
\text { Anos } \\
\end{array}$ & $\begin{array}{l}20-50 \\
\text { Anos }\end{array}$ & $\begin{array}{l}50- \\
100 \\
\text { Anos }\end{array}$ & $\begin{array}{l}100- \\
200 \\
\text { Anos }\end{array}$ & $\begin{array}{l}200- \\
1000 \\
\text { Anos } \\
\end{array}$ & $\begin{array}{l}\text { Mais } \\
\text { de } \\
1000 \\
\text { Anos } \\
\end{array}$ \\
\hline$\underset{* * *}{\text { Média Geral }}$ & 2,04 & 2,05 & 2,19 & 2,42 & 2,58 & 2,84 & 3,15 & 3,26 & 3,33 & 3,32 \\
\hline Homens & 2,12 & 2,15 & 2,21 & 2,48 & 2,69 & 2,91 & 3,24 & 3,37 & 3,31 & 3,31 \\
\hline Mulheres & 1,99 & 1,99 & 2,17 & 2,39 & 2,52 & 2,81 & 3,10 & 3,20 & 3,33 & 3,32 \\
\hline$<30$ Anos & 1,87 & 1,89 & 2,02 & 2,20 & 2,31 & 2,61 & 2,95 & 3,11 & 3,28 & 3,28 \\
\hline 30-50 Anos & 2,09 & 2,08 & 2,23 & 2,48 & 2,66 & 2,94 & 3,26 & 3,36 & 3,37 & 3,34 \\
\hline$>50$ Anos & 2,21 & 2,26 & 2,41 & 2,65 & 2,76 & 2,94 & 3,09 & 3,15 & 3,24 & 3,26 \\
\hline $\begin{array}{l}\text { Graduação } \\
\text { Completa }\end{array}$ & 2,16 & 2,21 & 2,35 & 2,57 & 2,70 & 2,88 & 3,10 & 3,14 & 3,15 & 3,19 \\
\hline $\begin{array}{l}\text { Graduação } \\
\text { Incompleta }\end{array}$ & 1,65 & 1,63 & 1,76 & 2,06 & 2,23 & 2,58 & 3,05 & 3,26 & 3,47 & 3,47 \\
\hline $\begin{array}{l}\text { Pós } \\
\text { Graduação }\end{array}$ & 2,33 & 2,31 & 2,47 & 2,64 & 2,84 & 3,18 & 3,40 & 3,51 & 3,51 & 3,40 \\
\hline Católica & 2,15 & 2,11 & 2,29 & 2,51 & 2,63 & 2,95 & 3,23 & 3,25 & 3,37 & 3,30 \\
\hline Judaica & 2,21 & 2,21 & 2,29 & 2,50 & 2,62 & 2,88 & 3,06 & 3,21 & 3,24 & 3,18 \\
\hline Evangélica & 1,85 & 2,00 & 2,15 & 2,38 & 2,77 & 3,00 & 3,15 & 3,31 & 3,38 & 3,46 \\
\hline Outras & 1,90 & 1,94 & 2,06 & 2,35 & 2,49 & 2,74 & 3,14 & 3,29 & 3,38 & 3,44 \\
\hline
\end{tabular}

\begin{tabular}{|c|c|c|c|c|}
\hline $\begin{array}{c}\text { 1-muito } \\
\text { otimista }\end{array}$ & $\begin{array}{c}\text { 2- um tanto } \\
\text { otimista }\end{array}$ & $\begin{array}{c}\text { 3- nem otimista nem } \\
\text { pessimista }\end{array}$ & $\begin{array}{c}\text { 4- um tanto } \\
\text { pessimista }\end{array}$ & $\begin{array}{c}\text { 5- muito } \\
\text { pessimista }\end{array}$ \\
\hline
\end{tabular}


De forma geral, os professores respondentes parecem acreditar que 0 futuro requer um alto grau de preparação ativa. A Tabela 20 sugere que, mesmo que o grau de planejamento tenda a diminuir à medida que os anos avancem, este ainda permaneça entre as categorias "alto" e "médio", mesmo para períodos onde anteriormente os respondentes afirmaram ter menos clareza ou preocupação com relação ao futuro (mais de 20 anos, por exemplo). As diferenças mais marcantes em termos demográficos referem-se aos períodos de tempo mais distantes (100 anos ou mais no futuro) e envolvem os professores evangélicos e os respondentes com graduação incompleta, cujas respostas aproximam-se mais do grau "médio" ou "mínimo" de preparação do que todos os outros respondentes. O padrão, no entanto, apresenta poucas nuances. A lógica aqui parece combinar a idéia de que, mesmo com uma tendência otimista em relação a este, o futuro é objeto de preocupação e preparação. Entretanto, como este é desconhecido, ele acaba por ser "deixado de lado" em termos da freqüência com a qual os respondentes pensam nele. De fato, mesmo o grau de preparação sugerido em relação ao futuro mais distante (mais de 1000 anos) é muito maior do que esperávamos e de certa forma, oferece um contraponto ao decrescente grau de preocupação demonstrado pelos respondentes para esse período.

Os homens, apesar de se preocuparem menos com o futuro, parecem apoiar um grau ligeiramente maior de preparação em relação a este do que as mulheres. O mesmo ocorre com os mais jovens com os respondentes mais velhos. Os professores de religião judaica apóiam um grau maior de preparação para o futuro, seguidos de perto pelos professores evangélicos e pelos professores de outras religiões, principalmente nos períodos futuros de curto e médio prazo. 
Tabela 20. "Qual deveria ser o grau de preparação ativa da humanidade para o futuro daqui a....?"

\begin{tabular}{|c|c|c|c|c|c|c|c|c|c|c|}
\hline & 1 ano & $\begin{array}{l}1-2 \\
\text { Anos }\end{array}$ & $\begin{array}{l}2-5 \\
\text { Anos }\end{array}$ & $\begin{array}{l}5-10 \\
\text { Anos }\end{array}$ & $\begin{array}{l}10-20 \\
\text { Anos }\end{array}$ & $\begin{array}{l}20-50 \\
\text { Anos }\end{array}$ & $\begin{array}{l}50- \\
100 \\
\text { Anos }\end{array}$ & $\begin{array}{l}100- \\
200 \\
\text { Anos }\end{array}$ & $\begin{array}{l}200- \\
1000 \\
\text { Anos }\end{array}$ & $\begin{array}{l}\text { Mais } \\
\text { de } \\
1000 \\
\text { Anos }\end{array}$ \\
\hline & 1,37 & 1,37 & 1,38 & 1,36 & 1,44 & 1,50 & 1,64 & 1,76 & 1,83 & 1,86 \\
\hline Homens & 1,34 & 1,32 & 1,28 & 1,26 & 1,40 & 1,46 & 1,62 & 1,74 & 1,82 & 1,86 \\
\hline Mulheres & 1,39 & 1,40 & 1,43 & 1,41 & 1,46 & 1,52 & 1,65 & 1,77 & 1,83 & 1,86 \\
\hline$<30$ Anos & 1,33 & 1,34 & 1,33 & 1,30 & 1,44 & 1,49 & 1,74 & 1,82 & 1,87 & 1,90 \\
\hline 30-50 Anos & 1,32 & 1,32 & 1,33 & 1,32 & 1,39 & 1,48 & 1,54 & 1,68 & 1,75 & 1,80 \\
\hline$>50$ Anos & 1,62 & 1,62 & 1,65 & 1,62 & 1,59 & 1,59 & 1,74 & 1,88 & 1,97 & 1,94 \\
\hline $\begin{array}{l}\text { Graduação } \\
\text { Completa }\end{array}$ & 1,41 & 1,41 & 1,43 & 1,41 & 1,44 & 1,48 & 1,58 & 1,67 & 1,74 & 1,80 \\
\hline $\begin{array}{l}\text { Graduação } \\
\text { Incompleta }\end{array}$ & 1,28 & 1,31 & 1,31 & 1,39 & 1,55 & 1,69 & 1,95 & 2,15 & 2,19 & 2,23 \\
\hline $\begin{array}{l}\text { Pós } \\
\text { Graduação }\end{array}$ & 1,42 & 1,40 & 1,38 & 1,22 & 1,29 & 1,29 & 1,36 & 1,44 & 1,51 & 1,49 \\
\hline Católica & 1,49 & 1,49 & 1,48 & 1,40 & 1,49 & 1,52 & 1,52 & 1,67 & 1,78 & 1,79 \\
\hline Judaica & 1,18 & 1,21 & 1,26 & 1,29 & 1,29 & 1,35 & 1,53 & 1,59 & 1,65 & 1,68 \\
\hline Evangélica & 1,31 & 1,38 & 1,54 & 1,54 & 1,77 & 1,85 & 2,15 & 2,46 & 2,54 & 2,58 \\
\hline Outras & 1,38 & 1,36 & 1,33 & 1,35 & 1,43 & 1,53 & 1,75 & 1,85 & 1,86 & 1,90 \\
\hline
\end{tabular}


Comparando as diferentes tabelas, podemos resumir as diferentes variáveis discutidas nas perguntas anteriores: pensar sobre o futuro, preocuparse com o futuro, imaginar o futuro, demonstrar otimismo ou pessimismo em relação ao futuro e planejar para o futuro. Podemos perceber que existe um relacionamento um tanto complexo entre os cinco aspectos em relação ao futuro apresentados e às variáveis demográficas: sexo, idade, formação e religião. Em determinadas situações, as diferenças são mais pronunciadas em termos de sexo (por exemplo, no planejamento para o futuro) ou por idade (por exemplo, pensar no futuro) ou por religião e formação (por exemplo, otimismo/ pessimismo em relação ao futuro).

Analisando-se esses cinco modos de "conceber" o futuro podemos concluir que os professores que pensam mais sobre o futuro são geralmente mais capazes de imaginá-lo. Como resultado, tendem também a se preocupar mais com o futuro e, portanto, apóiam de forma mais ativa o planejamento para este. Como poderia ser esperado, a preocupação e o otimismo têm uma co-relação negativa, ao contrário da capacidade de imaginar o futuro e o otimismo, que apresentam uma co-relação positiva. Tal achado, em relação à nossa amostra, aponta para a relevância da introdução de ferramentas para estudar o futuro, como a elaboração de cenários, por exemplo, para auxiliar as pessoas a melhor compreender e se preparar para o futuro. Poderíamos afirmar aqui que uma melhor compreensão leva a um melhor planejamento que, por sua vez, leva a um maior otimismo sobre o futuro. É de interesse também notar que as co-relações encontradas se apresentam de modo consistente através dos diferentes períodos de tempo no futuro, de forma menos acentuada no futuro a curto prazo, mas ainda assim mostrando essa relação positiva entre otimismo e planejamento.

Esperávamos também que os professores indicassem um alto grau de responsabilidade por parte da humanidade em diferentes questões que afetam nossas vidas. Os resultados, apresentados na Tabela 21 em geral correspondem à nossas expectativas. 
Tabela 21. "Como julgaria o grau de responsabilidade atual da humanidade no que diz respeito a questões futuras como...?"

\begin{tabular}{|l|c|c|c|c|}
\hline & $\begin{array}{c}\text { muito } \\
\text { responsável }\end{array}$ & $\begin{array}{c}\text { um pouco } \\
\text { responsável }\end{array}$ & $\begin{array}{c}\text { não muito } \\
\text { responsável }\end{array}$ & nada responsável \\
\hline $\begin{array}{l}\text { Aquecimento } \\
\text { Global }\end{array}$ & 43 & 20 & 21,5 & 15,5 \\
\hline Energia & 44,5 & 24 & 18,5 & 13 \\
\hline $\begin{array}{l}\text { Qualidade da } \\
\text { Água }\end{array}$ & 42 & 20 & 22,5 & 15,5 \\
\hline $\begin{array}{l}\text { Quantidade de } \\
\text { Água }\end{array}$ & 43,5 & 17,5 & 20 & 19 \\
\hline Biodiversidade & 37,5 & 22 & 26,5 & 14 \\
\hline Educação & 44,5 & 20,5 & 23 & 12 \\
\hline Qualidade de Vida & 41,5 & 26,5 & 22,5 & 9,5 \\
\hline Paz e Segurança & 42 & 15,5 & 23,5 & 19 \\
\hline Espiritualidade & 45,5 & 21 & 20,5 & 13 \\
\hline Economia & 38 & 24,5 & 24 & 13,5 \\
\hline Política & 38,5 & 22 & 23,5 & 16 \\
\hline $\begin{array}{l}\text { Novas } \\
\text { Tecnologias }\end{array}$ & 48,5 & 31,5 & 11 & 9 \\
\hline
\end{tabular}

(Porcentagem de Respondentes) 
Em 8 dos 12 temas, praticamente metade dos respondentes considera a humanidade "muito responsável" pela situação futura das questões apresentadas. A responsabilidade atribuída às outras questões também é relativamente alta. Entre as questões que inspiram maiores preocupações encontramos as novas tecnologias, a espiritualidade a energia e a educação. Tais resultados, apesar de serem aparentemente contraditórios em relação ao otimismo sugerido anteriormente, parecem mesclar aspectos de natureza pessoal e profissional dos respondentes e também, no caso da educação, parece apontar para um tipo de trabalho voltado ao futuro já realizado por estes junto aos alunos, provavelmente de natureza implícita. Não deixa de ser curioso notar os resultados atribuídos às novas tecnologias, uma vez que, ao mesmo tempo em que muitos atribuem a elas diversos problemas enfrentados pela humanidade, parece existir ainda a crença de que diversos desenvolvimentos tecnológicos em favor do meio ambiente ou do ser humano (como as experiências de natureza genética, por exemplo) tendam a serem mais benéficos à humanidade do que o contrário.

Os resultados da Tabela 22 são particularmente significantes para este trabalho. Ao responder qual seria o grau de preparação dos jovens em idade escolar para lidar com as questões propostas na pergunta anterior, os professores, em sua grande maioria, não acreditam que esse grau de preparação seja alto: a maioria das respostas (46\%) aponta um grau "baixo", seguido do "médio" (29,5\%) e, por fim, "sem preparação" (17,5\%). Curiosamente, as professoras tendem a uma visão mais negativa dos jovens do que os professores homens: $33 \%$ das professoras consideram esse grau baixo, contra apenas $13 \%$ dos homens. Aliás, os homens apresentam maior semelhança de respostas entre os graus "médio" e "baixo", ao contrário das professoras, por exemplo. A distribuição das respostas nas outras categorias segue um padrão mais equilibrado, semelhante ao dos homens, com exceção dos respondentes entre $30-50$ anos (26,5\%), daqueles com formação completa (24,5\%) e dos professores católicos $(21,5 \%)$, com uma proporção maior de respostas na categoria "baixo". 
Tabela 22. "Na sua opinião, qual o grau de preparação dos jovens em idade escolar para lidar com essas questões do futuro?"

\begin{tabular}{|l|c|c|c|c|}
\hline & 1 - alto & 2- médio & 3- baixo & 4- sem preparação \\
\hline Total & 7,00 & 29,50 & 46,00 & 17,50 \\
\hline Homens & & & & \\
\hline Mulheres & 7,35 & 32,35 & 38,24 & 22,06 \\
\hline & 6,82 & 28,03 & 50,00 & 15,15 \\
\hline$<30$ Anos & & & & \\
\hline $30-50$ Anos & 4,45 & 35,48 & 46,77 & 11,29 \\
\hline$>50$ Anos & 13,89 & 28,43 & 51,96 & 14,71 \\
\hline & & 22,22 & 27,78 & 36,11 \\
\hline Graduação & 4,35 & & & 13,04 \\
\hline Completa & & 29,35 & 53,26 & 28,57 \\
\hline Graduação & 3,17 & & & 24,44 \\
\hline Incompleta & 11,11 & 26,67 & 37,78 & \\
\hline Pós Graduação & & & & 33,33 \\
\hline & 8,62 & 34,48 & 74,14 & 34,48 \\
\hline & 9,52 & 64,29 & 45,24 & 19,05 \\
\hline Católica & 2,38 & 26,19 & 57,14 & \\
\hline Judaica & 8,33 & 8,33 & 50,00 & \\
\hline Evangélica & & & & \\
\hline Outras & & & & \\
\hline
\end{tabular}

(Porcentagem de Respondentes) 
Não seria de se estranhar, portanto, que os resultados da Tabela 23 estejam de acordo com as respostas dos professores que foram dadas à pergunta anterior. Em relação à oferta de algum tipo de preparação para lidar com as questões do futuro, dentro da escola, as respostas obtidas refletiram de maneira quase que uniforme os resultados da tabela anterior: os professores, em sua maior parte, indicam que a escola oferece esse trabalho com "pouca" (47\%) ou "alguma freqüência" (38\%). Somente $10 \%$ das respondentes acreditam que essa freqüência é alta. No entanto, ao contrário da resposta anterior, que até apontava para um grau nulo de preparação dos alunos nesse sentido, somente $5 \%$ dos professores acredita que a escola nunca oferece esse tipo de preparação. As outras categorias refletem a distribuição de respostas encontradas na tabela anterior, com uma predominância de repostas na categoria "pouca freqüência" nos mesmos grupos em destaque na tabela anterior: mulheres $(33,5 \%)$, respondentes na faixa entre $30-50$ anos $(23 \%)$, respondentes com formação completa $(22,5 \%)$ e professores católicos $(25,5 \%)$. Tais resultados parecem confirmar uma das premissas identificadas em relação à atividade escolar e aos estudos do futuro: existe uma preocupação nesse tipo de preparação por parte dos professores, que a vêem como parte de suas funções educacionais (daí a baixa ocorrência de respostas na categoria "nunca"). Por outro lado, como essa preparação parece ser feita de modo não freqüente e implícito, os professores vêem o grau de preparação dos alunos em relação a estas de maneira mais negativa. 
Tabela 23- "Na sua opinião, a educação escolar oferece essa preparação aos jovens para lidar com questões do futuro?"

\begin{tabular}{|c|c|c|c|c|}
\hline & 1-muita freqüência & $\begin{array}{l}\text { 2-alguma } \\
\text { freqüência }\end{array}$ & $\begin{array}{l}\text { 3-pouca } \\
\text { freqüência }\end{array}$ & 4-nunca \\
\hline Total & 10,00 & 38,00 & 47,00 & 5,00 \\
\hline Homens & 11,76 & 38,24 & 44,12 & 5,88 \\
\hline Mulheres & 6,82 & 37,88 & 50,76 & 4,55 \\
\hline$<30$ Anos & 12,90 & 35,48 & 46,77 & 4,84 \\
\hline 30-50 Anos & 7,84 & 43,14 & 45,10 & 3,92 \\
\hline$>50$ Anos & 11,11 & 27,78 & 52,78 & 8,33 \\
\hline $\begin{array}{l}\text { Graduação } \\
\text { Completa }\end{array}$ & 8,70 & 39,13 & 48,91 & 3,26 \\
\hline $\begin{array}{l}\text { Graduação } \\
\text { Incompleta }\end{array}$ & 12,70 & 30,16 & 49,21 & 6,35 \\
\hline Pós Graduação & 8,89 & 46,67 & 37,78 & 6,67 \\
\hline Católica & 11,36 & 43,10 & 87,93 & 3,45 \\
\hline Judaica & 6,90 & 57,14 & 66,67 & 4,76 \\
\hline Evangélica & 7,14 & 7,50 & 10,00 & 2,00 \\
\hline Outras & 8,33 & 33,33 & 50,00 & 8,33 \\
\hline
\end{tabular}


A tabela seguinte (24) apresenta perguntas adicionais relativas ao controle percebido pelos professores em relação ao seu próprio futuro e aquele da humanidade. A maior parte deles (54\%) "concorda em termos" com a idéia de um controle completo sobre seu futuro pessoal, ao mesmo tempo em que "concorda plenamente" $(47,5 \%)$ com a diversidade caminhos para esse futuro. otimismo em relação ao futuro identificado em perguntas anteriores é confirmado aqui (36\% "concordam plenamente" e $46 \%$ "concordam em termos" com essa afirmação, totalizando $81 \%$ da amostra). Tal otimismo é curioso, já que a maioria (46\%) "concorda em termos" com a rápida velocidade das mudanças e a dificuldade de controle sobre estas. Mais uma vez, poucos professores $(11,5 \%)$ acreditam que seus futuros serão radicalmente diferentes do presente e menos professores ainda (9\%) vêem seus futuros como iguais ao presente.

Ao contrário da visão de controle sobre seus futuros pessoais, uma grande proporção deles $(48,5 \%)$ "discorda plenamente" de que a humanidade possa ter controle completo sobre seu futuro, ao mesmo tempo em que "concordam plenamente" $(40 \%)$ que existam vários caminhos para ela. Tal contraste também está presente no grau de otimismo em relação ao futuro da humanidade, que é menor do que aquele mostrado com o futuro pessoal: a maior quantidade de respostas aqui ficando na categoria "concordam em termos" (45\%) ou "discordo em termos" (29\%). O menor otimismo verificado nesse padrão é refletido nas respostas em relação à velocidade de mudanças e o controle da humanidade sobre estas (42,5\% e $31,5 \%$ respectivamente), assim como na diferença entre o futuro da humanidade e seu presente ( $54 \%$ e $22 \%$, respectivamente). 
Tabela 24. Por favor, indique o seu grau de concordância ou discordância das afirmações abaixo:

\begin{tabular}{|l|c|c|c|c|}
\hline & $\begin{array}{c}\text { 1- concordo } \\
\text { plenamente }\end{array}$ & $\begin{array}{c}\text { 2- concordo } \\
\text { em termos }\end{array}$ & $\begin{array}{c}\text { 3- discordo } \\
\text { em termos }\end{array}$ & $\begin{array}{c}\text { 4- discordo } \\
\text { plenamente }\end{array}$ \\
\hline Tenho controle completo do meu futuro. & 9 & 54 & 22 & 15 \\
\hline Existem vários caminhos para meu futuro. & 47,5 & 42 & 9,5 & 1 \\
\hline Sou otimista em relação ao futuro. & 35 & 46 & 13,5 & 5,5 \\
\hline $\begin{array}{l}\text { As mudanças são rápidas demais para que eu as } \\
\text { controle. }\end{array}$ & 16 & 48 & 29,5 & 6,5 \\
\hline $\begin{array}{l}\text { Meu futuro será radicalmente diferente do meu } \\
\text { presente. }\end{array}$ & 11,5 & 40,5 & 38,5 & 9,5 \\
\hline $\begin{array}{l}\text { A humanidade tem controle completo } \\
\text { de seu futuro. }\end{array}$ & 3 & 19,5 & 29 & 48,5 \\
\hline $\begin{array}{l}\text { Existem vários caminhos para futuro da } \\
\text { humanidade. }\end{array}$ & 40 & 35 & 19 & 6 \\
\hline $\begin{array}{l}\text { Sou otimista em relação ao futuro da } \\
\text { humanidade. }\end{array}$ & 11,5 & 45 & 29 & 14,5 \\
\hline $\begin{array}{l}\text { As mudanças são rápidas demais para que a } \\
\text { humanidade as controle. }\end{array}$ & 19,5 & 42,5 & 31,5 & 6,5 \\
\hline $\begin{array}{l}\text { O futuro da humanidade será radicalmente } \\
\text { diferente do seu presente. }\end{array}$ & 9 & 54 & 22 & 15 \\
\hline
\end{tabular}


Em geral, podemos perceber que os professores tendem a discordar da idéia de que o mundo possa mudar de maneira imprevisível. Eles tendem a acreditar que têm algum controle sobre seu futuro e que existem diversos caminhos à sua frente, mesmo que esses os levem a uma vida radicalmente diferente daquela que têm no momento presente.

De forma interessante, os professores tendem a acreditar mais no controle de seu próprio futuro do no controle do futuro da humanidade. Considerando-se que cada individuo é parte de um sistema e que o sistema em um todo, deveria refletir esse comportamento de controle, nos parece que os professores responderam pensando em seus futuros como períodos mais limitados em termos de tempo do que os períodos que eles imaginaram para o futuro da humanidade.

A pergunta seguinte refere-se ao período de tempo no futuro no qual os respondentes gostariam de nascer. Como esse é naturalmente um exercício imaginativo que leva em consideração tanto as questões do futuro como as opiniões dos professores a respeito delas, não deixa de ser curioso notar que o grau de clareza com o qual os professores vêem o futuro encontra-se refletido nas respostas da Tabela 25, com apenas uma exceção: a curva de respostas encontra seus pontos mais altos ou no futuro imediato ( 1 ano) ou em um futuro muito distante (mais de 100.000 anos). A indicação mais próxima pode sugerir que estes estão satisfeitos com sua vida atual e que poderiam reiniciá-la em um futuro bem próximo, onde já seriam beneficiados pelos avanços esperados em qualidade do meio ambiente ou de um crescimento na expectativa de vida, por exemplo. As mulheres indicaram uma maior propensão a querer nascer em períodos futuros mais próximos do que os homens, entre 100 e 1000 anos. Em termos de religião, os professores judeus e católicos tendem a escolher os períodos futuros mais próximos do que as outras religiões. 
Tabela 25. "Caso pudesse nascer no futuro, indique quando gostaria de nascer: daqui a..."

\begin{tabular}{|l|c|c|c|c|c|c|c|c|c|}
\hline & $\begin{array}{c}1 \\
\text { Ano }\end{array}$ & $\begin{array}{c}10 \\
\text { Anos }\end{array}$ & $\begin{array}{c}50 \\
\text { Anos }\end{array}$ & $\begin{array}{c}100 \\
\text { Anos }\end{array}$ & $\begin{array}{c}500 \\
\text { Anos }\end{array}$ & $\begin{array}{c}1000 \\
\text { Anos }\end{array}$ & $\begin{array}{c}5000 \\
\text { Anos }\end{array}$ & $\begin{array}{c}10000 \\
\text { Anos }\end{array}$ & $\begin{array}{c}100000 \\
\text { Anos }\end{array}$ \\
\hline Total & 15,00 & 10,50 & 13,50 & 12,00 & 6,00 & 5,50 & 4,00 & 9,00 & 15,00 \\
\hline Homens & 7,35 & 5,88 & 10,29 & 17,65 & 5,88 & 4,41 & 5,88 & 13,24 & 7,35 \\
\hline Mulheres & 17,42 & 11,36 & 13,64 & 7,58 & 5,30 & 5,30 & 3,03 & 6,82 & 17,42 \\
\hline & & & & & & & & & \\
\hline$<30$ Anos & 22,58 & 9,68 & 8,06 & 11,29 & 4,84 & 6,45 & 3,23 & 8,06 & 22,58 \\
\hline 30-50 Anos & 7,84 & 10,78 & 16,67 & 13,73 & 6,86 & 6,86 & 3,92 & 8,82 & 7,84 \\
\hline$>50$ Anos & 0,00 & 5,56 & 11,11 & 16,67 & 0,00 & 0,00 & 15,43 & 30,86 & 46,30 \\
\hline & & & & & & & & & \\
\hline $\begin{array}{l}\text { Graduação } \\
\text { Completa }\end{array}$ & 17,39 & 8,70 & 18,48 & 9,78 & 5,43 & 6,52 & 3,26 & 7,61 & 17,39 \\
\hline $\begin{array}{l}\text { Graduação } \\
\text { Incompleta }\end{array}$ & 17,46 & 15,87 & 11,11 & 11,11 & 4,76 & 3,17 & 4,76 & 3,17 & 17,46 \\
\hline $\begin{array}{l}\text { Pós } \\
\text { Graduação }\end{array}$ & 6,67 & 6,67 & 6,67 & 17,78 & 8,89 & 6,67 & 4,44 & 17,78 & 6,67 \\
\hline & 16,67 & 0,00 & 16,67 & 25,00 & 8,33 & 0,00 & 25,00 & 8,33 & 16,67 \\
\hline & 11,36 & 7,95 & 13,64 & 7,95 & 5,68 & 7,95 & 1,14 & 5,68 & 11,36 \\
\hline Católica & 15,52 & 13,79 & 13,79 & 18,97 & 3,45 & 6,90 & 1,72 & 13,79 & 15,52 \\
\hline Judaica & & & & & & & & \\
\hline Evangélica & 21,43 & 14,29 & 9,52 & 4,76 & 9,52 & 0,00 & 7,14 & 4,76 & 21,43 \\
\hline Outras & & & & & & & & & \\
\hline
\end{tabular}


Contudo, em nossa amostra podemos perceber que a maior incidência de respostas escolhendo um nascimento em um futuro distante, em diversas categorias, parece sugerir que os respondentes vejam tais períodos como bem diversos do período atual, um tempo onde diversos problemas atuais já terão sido resolvidos ou o mundo será bastante distinto. Tais resultados não deixam de ser curiosos, principalmente se comparados com os resultados da pergunta seguinte.

As últimas perguntas do questionário abordam a extinção da humanidade. Após diversas perguntas sobre o futuro desta, foi relativamente surpreendente perceber que 55,5\% dos professores acreditam que ela terá fim (Tabela 26). Mais surpreendente foi perceber que o otimismo daqueles com menos de 30 anos identificado em perguntas anteriores se transforma aqui em quase que certeza sobre o fim da humanidade (80,6\%). Entre aqueles que também demonstraram mais crença no fim da humanidade também estão os homens $(64,7 \%)$, os professores de outras religiões (66,6\%), os professores judeus $(65,5 \%)$ e as pessoas com mais de 50 anos (63,8\%). A única categoria que demonstra uma crença menor na extinção da humanidade seria aquela dos professores com um pouco mais de experiência, na faixa dos 30-50 anos (apenas 36,2\%). Essa é uma questão de relevância para o trabalho com os estudos do futuro, pois de que adiantaria o apoio ao planejamento se, a longo prazo, todas as conquistas da humanidade serão inúteis? 
Tabela 26. "Acredita que a humanidade um dia se extinguirá?"

\begin{tabular}{|l|c|c|}
\hline & Sim & Não \\
\hline Geral & 55,5 & 44,5 \\
\hline Homens & & 35,3 \\
\hline Mulheres & 64,7 & 49,3 \\
\hline & 50,7 & \\
\hline$<30$ Anos & & 19,4 \\
\hline $30-50$ Anos & 80,6 & 63,8 \\
\hline$>50$ Anos & 36,2 & 36,2 \\
\hline & 63,8 & \\
\hline Graduação Completa & & 45,7 \\
\hline Graduação Incompleta & 54,3 & 41,3 \\
\hline Pós Graduação & 58,7 & 48,8 \\
\hline & 51,2 & \\
\hline Católica & & 48,9 \\
\hline Judaica & 51,1 & 34,5 \\
\hline Evangélica & 65,5 & 54,8 \\
\hline Outras & 45,2 & 33,4 \\
\hline
\end{tabular}


Para aqueles que acreditam na extinção da humanidade, perguntamos também quando (Tabela 27) e por que (Tabela 28) isso ocorreria. Os respondentes poderiam nesse caso, assinalar uma diversidade de causas. No caso da primeira pergunta, as respostas parecem sugerir, pelo padrão verificado, esse fim para os próximos 500 anos ou um período muito distante, daqui a mais de 100.000 anos,. Dos professores que responderam "sim" à pergunta sobre a extinção, apenas $6 \%$ afirmam não saber quando isso ocorrerá. Mais uma vez, as respostas parecem acompanhar o padrão de clareza com a qual os professores enxergam o futuro, escolhendo ou um futuro relativamente próximo (500 anos) onde a deterioração dos sistemas naturais causada pelo homem pode trazer o fim ou um futuro mais distante e "obscuro", caracterizado pelo desconhecido (no caso, o fim da humanidade).

No caso da segunda pergunta, as razões que levarão à extinção são, em um primeiro grupo, o fim dos recursos naturais e a degradação ambiental $(77 \%$ e $74 \%$ de ocorrências); em segundo lugar, desastres naturais e guerras $(63 \% \mathrm{e}$ $61 \%$, respectivamente); os problemas relativos ao crescimento desenfreado, causados por doenças e epidemias resultantes de mudanças climáticas e da superpopulação vêm em terceiro lugar (55\%, 51\% e 49\%). Poucos respondentes acreditam na extinção causada por conflitos religiosos (33\%) ou outros fatores $(27 \%)$ e menos deles ainda (5\%) afirmam desconhecer alguma causa para o fim da humanidade. 
Tabela 27. "Quando a humanidade se extinguirá?"

\begin{tabular}{|l|c|c|c|c|c|c|c|c|c|}
\hline & $\begin{array}{c}\text { Não } \\
\text { sei }\end{array}$ & $\begin{array}{c}10 \\
\text { Anos }\end{array}$ & $\begin{array}{c}50 \\
\text { Anos }\end{array}$ & $\begin{array}{c}100 \\
\text { Anos }\end{array}$ & $\begin{array}{c}500 \\
\text { Anos }\end{array}$ & $\begin{array}{c}1000 \\
\text { Anos }\end{array}$ & $\begin{array}{c}5000 \\
\text { Anos }\end{array}$ & $\begin{array}{c}10000 \\
\text { Anos }\end{array}$ & $\begin{array}{c}100000 \\
\text { Anos }\end{array}$ \\
\hline Total & 19,00 & 1,50 & 1,00 & 3,00 & 9,50 & 3,00 & 3,00 & 4,00 & 11,50 \\
\hline Homens & 16,18 & 1,47 & 1,47 & 2,94 & 10,29 & 4,41 & 2,94 & 5,88 & 19,12 \\
\hline Mulheres & 12,88 & 1,52 & 0,76 & 3,03 & 9,09 & 2,27 & 3,03 & 3,03 & 7,58 \\
\hline & & & & & & & & & \\
\hline$<30$ Anos & 40,32 & 0,00 & 1,61 & 1,61 & 11,29 & 3,23 & 6,45 & 3,23 & 12,90 \\
\hline 30-50 Anos & 3,92 & 0,98 & 0,00 & 2,94 & 8,82 & 1,96 & 1,96 & 4,90 & 10,78 \\
\hline$>50$ Anos & 5,56 & 0,00 & 2,78 & 11,11 & 0,00 & 15,43 & 0,00 & 7,72 & 30,86 \\
\hline & & & & & & & & & \\
\hline $\begin{array}{l}\text { Graduação } \\
\text { Completa }\end{array}$ & 18,48 & 1,09 & 1,09 & 2,17 & 8,70 & 3,26 & 2,17 & 4,35 & 13,04 \\
\hline $\begin{array}{l}\text { Graduação } \\
\text { Incompleta }\end{array}$ & 12,70 & 1,59 & 1,59 & 1,59 & 11,11 & 1,59 & 6,35 & 6,35 & 15,87 \\
\hline $\begin{array}{l}\text { Pós } \\
\text { Graduação }\end{array}$ & 26,67 & 2,22 & 0,00 & 6,67 & 8,89 & 4,44 & 0,00 & 0,00 & 2,22 \\
\hline & 13,79 & 0,00 & 0,00 & 1,72 & 6,90 & 1,72 & 0,00 & 1,72 & 6,90 \\
\hline Católica & 4,55 & 4,55 & 3,41 & 9,09 & 0,00 & 5,17 & 5,17 & 3,87 & 10,33 \\
\hline Judaica & 13,64 & 2,27 & 1,14 & 1,14 & 9,09 & 1,14 & 1,14 & 4,55 & 9,09 \\
\hline Evangélica & 1,76 & 0,00 & 0,00 & 2,38 & 2,38 & 0,00 & 2,38 & 0,00 & 7,14 \\
\hline Outras & & & & & & & & & \\
\hline
\end{tabular}

(Porcentagem de Respondentes) 
Tabela 28. "Por que a humanidade se extinguirá?" (Assinale uma ou mais respostas)

\begin{tabular}{|l|c|}
\hline Conflitos religiosos & 33 \\
\hline Evolução & 17 \\
\hline Superpopulação & 49 \\
\hline Mudança Climática & 51 \\
\hline Degradação ambiental & 74 \\
\hline Guerras & 61 \\
\hline Desastres Naturais & 63 \\
\hline Extinção Natural & 30 \\
\hline Fim dos recursos naturais & 77 \\
\hline Doenças /epidemias & 55 \\
\hline Outros & 27 \\
\hline Não sei & 5 \\
\hline
\end{tabular}

(Porcentagem de Ocorrência das Causas Sugeridas) 
Os resultados apontam para um grau de consciência dos diversos fatores que afetam a vida atual dos professores. Em conseqüência, nos parece que, à medida que estes se vêem menos capazes de agir, em termos de planejamento, menos esperançosos se tornam em relação ao futuro. Parece haver uma dicotomia marcada entre aquilo que eles esperam para o futuro e aquilo que acreditam que irá acontecer. Tal dicotomia parece também refletir o grau de otimismo somado ao grau de preocupação desses professores em relação ao futuro. A crença em planejamento ativo parece esbarrar na dificuldade de conceber como esse futuro pode se desenrolar, gerando visões de longo mais prazo mais negativas.

\subsection{REALIZAÇÃO DAS OFICINAS PARA APRESENTAÇÃO DOS ESTUDOS DO FUTURO NAS ESCOLAS: COLETA DE DADOS ADICIONAIS}

Novos contatos foram efetuados com as escolas participantes logo após a retirada dos questionários da primeira fase, com o intuito de verificar se a oficina de apresentação dos estudos do futuro poderia ser realizada. Como já haviam sugerido, as duas escolas da rede pública participantes da primeira fase não conseguiram combinar o interesse demonstrado pela pesquisa com a realização de uma oficina com seus professores. Entre as razões alegadas estavam o excesso de atividades dos professores e a falta de data útil para reunir os professores para tal atividade.

No caso do grupo de alunos da UNIBAN, o convite para a oficina após o horário das aulas foi aceito e a oficina foi realizada em dois dias consecutivos, com a distribuição do segundo questionário imediatamente após o término da segunda parte da oficina. Dos 26 respondentes do questionário na primeira fase, 
apenas um não compareceu às duas datas da oficina, razão pela qual sua resposta foi desconsiderada, perfazendo um total de 25 questionários.

As escolas particulares, na maior parte, mostraram interesse que a oficina fosse realizada o mais breve possível após a retirada dos questionários da primeira fase. Mais uma vez, nem todos os respondentes que participaram do primeiro questionário compareceram à oficina, a critério da coordenação e direção das escolas. No caso do Colégio Bandeirantes, 14 professores participaram da oficina, sendo que no Colégio I. L. Peretz o número de presentes foi de 40. A oficina do Colégio Sidarta contou com 25 professores. O segundo questionário foi distribuído também imediatamente após a segunda oficina, sendo que estes seriam coletados posteriormente pela coordenação. O número de questionários completamente preenchidos e devolvidos foi geralmente alto (todos os 14 no Bandeirantes, 28 no I.L. Peretz e 13 no Sidarta), sendo que mais uma vez, os questionários incompletos não foram considerados.

As oficinas, por sua vez, transcorreram como planejado e foram realizadas em um só dia (exceto no caso dos alunos da UNIBAN), durando cerca de 120 minutos cada, entre os meses de junho e meados de agosto de 2007. Durante a apresentação foi possível perceber um grau de interesse pelo assunto, e à medida que os professores esclareciam suas dúvidas sobre os a natureza e ferramentas dos estudos do futuro que poderiam usar com seus alunos, maior parecia ser a certeza destes de que tal abordagem oferecia uma ótica para o trabalho que muitos já realizavam com os alunos. Alguns professores buscaram o pesquisador ao final da oficina para confirmar se o tipo de pesquisa que realizavam se enquadrava em alguma das abordagens apresentadas. Mais uma vez, a coordenação das escolas indicou que, a partir do interesse demonstrado pelos professores nos resultados dos questionários da segunda fase, alguma atividade ou projeto poderia ser implementada. Passemos então agora à apresentação dos resultados do segundo questionário. 


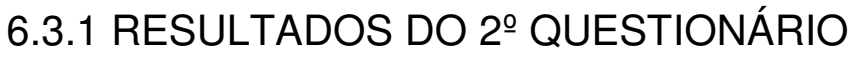

Na segunda fase da investigação, mantivemos a mesma abordagem de análise dos resultados da fase anterior. Apesar da maior especificidade deste em relação à oficina de apresentação dos estudos do futuro e seu conteúdo, a estrutura das questões foi semelhante àquela existente no primeiro questionário.

Desta vez, a pesquisa limitou-se às escolas cuja coordenação ou direção ofereceram a oportunidade da realização da oficina de familiarização com o ensino do futuro. Dessa maneira, o acesso aos professores (no nosso caso, os agentes principais relacionados à implementação de inovações curriculares) foi mais uma vez encorajado por um "nível hierárquico" acima, apesar da proposta do pesquisador não oferecer um caráter impositivo nesse sentido. Portanto, a seleção da amostra apresenta outro processo de filtragem e, mesmo se a amostragem é ainda mais reduzida relação ao total da população de professores, ela é, desta vez, de caráter bastante representativo em relação à amostragem original (Gil: 1999). Para um coeficiente de confiança de $95 \%$ na interpretação das médias relacionadas a respostas qualitativas, a margem de erro adotada foi também de 0,13. Para o mesmo coeficiente de confiança em respostas envolvendo porcentagens, o coeficiente de confiança adotado foi de $5 \% \mathrm{em}$ relação aos valores levantados. Ainda assim, os dados serão interpretados mais uma vez com base nas variações encontradas em cada um dos estratos e como essas variações demonstram semelhança ou diferença em relação às variações dos outros estratos e não necessariamente através da comparação de cada um dos sub-estratos.

Em segundo lugar, apesar da amostragem ser representativa em relação à primeira mostra, pelo fato de usar parte dos integrantes da amostra original e assim manter o padrão randômico anterior, não podemos tampouco afirmar que X\% da população dos professores da cidade de São Paulo, por exemplo, teriam uma determinada percepção do que envolveriam os "estudos do futuro" a partir 
da realização de apenas uma oficina de familiarização. Podemos somente afirmar qual porcentagem de nossa amostra partilha de determinadas percepções encontradas, e presumir uma possível semelhança de percepções. Acreditamos, porém, ser mais importante ainda revelar a outros estudiosos do futuro de quais maneiras tais abordagens são percebidas pelos professores que participaram da oficina. Outros trabalhos voltados à implementação destas abordagens poderão se utilizar destes dados para comparar as diferentes percepções de outros grupos de professores ou até mesmo para orientar a forma como estas abordagens podem ser realizadas.

Por fim, como a composição de nossa amostra concentra-se em professores cujas escolas demonstraram interesse em saber mais sobre tais abordagens, podemos também presumir que as respostas refletirão de maneira mais nítida ambientes onde a inovação curricular pode ocorrer de forma mais ágil, e não somente, imaginamos, inovações voltadas à introdução dos estudos do futuro. Esperamos que pesquisas futuras investiguem a natureza desses estabelecimentos em relação à questão de introdução de inovações curriculares de diferentes tipos, por exemplo.

\subsubsection{RESPONDENTES}

Oitenta indivíduos completaram a segunda fase da pesquisa. A Tabela 29 apresenta a distribuição de respondentes de acordo com suas instituições de origem. O grupo predominante na amostra foi o dos professores que atuam em escolas da rede particular (67\%), com o restante (33\%) formado pelo grupo de professores atuantes na rede pública que buscam certificação.

A Tabela 30 apresenta as características demográficas dos respondentes. A segunda amostra ainda mantém uma distribuição semelhante à da primeira. Mais uma vez, a maior parte dos respondentes é do sexo feminino (60\%). A distribuição de faixas etárias mostra uma preponderância da faixa entre 
$30-50$ anos de idade (57,5\%), seguida pela faixa dos com menos de $30(27,5 \%)$ e, por fim dos respondentes com mais de 50 anos de idade (15\%). Outros aspectos da amostra mostram uma distribuição mais equilibrada em comparação com a primeira amostra: a maior parte dos respondentes (32,5\%) possui entre 5 e 15 anos de experiência, desta vez seguida de perto (27,5\%) pelo grupo que está na fase inicial de suas carreiras ( 0 a 5 anos de experiência); os grupos que possuem entre 15 e 20 anos ou mais de experiência profissional encontram-se representados de maneira bastante semelhante $(17,5 \%$ e $22,5 \%$ respectivamente). Desta vez, os dados referentes à experiência dos professores serão comparados para que possamos analisá-los em relação aos outros estratos, no que diz respeito à adoção de abordagens voltadas ao ensino do futuro em sala de aula.

A distribuição encontrada em relação à formação também é semelhante: a maioria (40\%) é graduada. Houve, porém uma inversão que acreditamos ser relevante: o segundo grupo mais relevante agora é o de professores com pósgraduação (32,5 \%), ficando em último lugar o grupo de professores cuja graduação universitária é incompleta (31,5\%). Acreditamos que tal fato possa favorecer uma análise mais embasada das abordagens voltadas ao ensino de futuro (já que mais de $70 \%$ dos professores tem maior grau de formação).

Os respondentes também apresentam uma diversidade de crenças religiosas em proporção semelhante à da amostra original: a maior parte deles continua católica $(36,25 \%)$; seguida pelos de fé judaica $(32,5 \%)$ e os de fé evangélica (17,5\%). Outras religiões (budismo, espiritismo) continuam menos representadas na amostra, mas em maior proporção do que antes (13,75\%). 
Tabela 29. Distribuição por Instituição

\begin{tabular}{|l|c|c|}
\hline & Homens & Mulheres \\
\hline Colégio Bandeirantes & 4 & 10 \\
\hline Colégio L. Peretz & 13 & 15 \\
\hline Colégio Sidarta & 4 & 9 \\
\hline UNIBAN & 11 & 14 \\
\hline & $40 \%$ & $60 \%$ \\
\hline
\end{tabular}


Tabela 30 . Distribuição Demográfica da Amostra

\begin{tabular}{|c|c|c|c|c|c|}
\hline Sexo & Masculino & Feminino & & & Totais \\
\hline & 32 & 48 & & & 80 \\
\hline Idade & $<30$ & $30-50$ & $>50$ & & \\
\hline Homens & 10 & 18 & 4 & & 80 \\
\hline Mulheres & 12 & 28 & 8 & & \\
\hline $\begin{array}{l}\text { Experiência como } \\
\text { Educador em anos }\end{array}$ & $0-5$ & $5-15$ & $15-20$ & +20 & \\
\hline Homens & 9 & 12 & 5 & 6 & 80 \\
\hline Mulheres & 13 & 14 & 9 & 12 & \\
\hline Formação & $\begin{array}{l}\text { Graduação } \\
\text { Incompleta }\end{array}$ & $\begin{array}{c}\text { Graduação } \\
\text { Completa }\end{array}$ & $\begin{array}{c}\text { Pós- } \\
\text { graduação }\end{array}$ & & \\
\hline Homens & 10 & 13 & 9 & & 80 \\
\hline Mulheres & 12 & 19 & 17 & & \\
\hline Religião & Católica & Judaica & Evangélica & Outras & \\
\hline Homens & 7 & 16 & 4 & 5 & 80 \\
\hline Mulheres & 22 & 10 & 10 & 6 & \\
\hline
\end{tabular}

(Número de Respondentes) 
Apesar de incluídos no questionário, os dados referentes à religião dos professores não serão analisados nessa segunda fase: eles foram coletados para que os questionários indicassem o grau de diversidade demográfica da amostra em comparação com à primeira fase. Contudo, acreditamos que as categorias envolvendo experiência profissional e a formação acadêmica seriam mais relevantes em determinar a adoção de abordagens relacionadas ao ensino do futuro em sala de aula do que as crenças religiosas.

\subsubsection{DISCUSSÃO DOS RESULTADOS DO 2ํQ QUESTIONÁRIO}

Os resultados a seguir foram analisados em relação aos estratos demográficos incluídas na amostra e suas variações. Confirmando um dos pressupostos, a Tabela 31 mostra que os professores demonstraram um grau de compreensão razoável em relação à natureza dos estudos do futuro. As médias de todas as categorias são bastante próximas e os indicadores mais relevantes aqui apontam para uma possível melhor compreensão por parte dos professores com menos de 30 anos, em contraste com as médias apresentadas pelos com mais de 50 anos e aqueles com pós-graduação ou com mais de 20 anos de experiência, que apresentaram médias menores.

Um resultado curioso pode ser encontrado na Tabela 32: apesar das médias indicarem que os professores emprestam um grau relevância razoável aos estudos do futuro, os resultados mostram consistentemente que eles percebem, a priori, tais estudos como mais relevantes para eles próprios do que para seus alunos. Isso pode significar que não só eles gostariam de saber mais sobre o futuro para seus próprios interesses como também podem preferir aprender mais sobre tais estudos antes de utilizá-los com seus alunos. Apesar de pequenas variações entre os resultados, os respondentes colocam a relevância dos estudos para a sociedade como um todo em grau inferior ao que atribuem para si próprios ou para os alunos. Isso parece sugerir uma diversidade entre interesses pessoais, profissionais e pelo coletivo. 
Tabela 31. "Em relação à natureza dos 'estudos do futuro', posso dizer que... ?"

\begin{tabular}{|c|c|}
\hline & Nível de compreensão \\
\hline Média Geral & 2,45 \\
\hline Homens & 2,45 \\
\hline Mulhere & 2,45 \\
\hline$<30$ Anos & 2,62 \\
\hline 30-50 Anos & 2,40 \\
\hline$>50$ Anos & 2,34 \\
\hline Graduação Completa & 2,55 \\
\hline Graduação Incompleta & 2,50 \\
\hline Pós Graduação & 2,28 \\
\hline$<5$ anos de experiência & 2,50 \\
\hline 5 a 15 anos de experiência & 2,36 \\
\hline 15 a 20 anos de experiência & 2,69 \\
\hline Mais de 20 anos de experiência & 2,33 \\
\hline
\end{tabular}

\begin{tabular}{|c|c|c|}
\hline $\begin{array}{c}\text { 1- não compreendi } \\
\text { bem }\end{array}$ & $\begin{array}{c}\text { 2- tenho uma } \\
\text { compreensão } \\
\text { razoável }\end{array}$ & $\begin{array}{c}\text { 3- tenho uma boa } \\
\text { compreensão }\end{array}$ \\
\hline
\end{tabular}


Tabela 32. "Em relação à relevância dos estudos do futuro, posso dizer que são... ?"

\begin{tabular}{|l|c|c|c|}
\hline & $\begin{array}{c}\text { para } \\
\text { mim }\end{array}$ & $\begin{array}{c}\text { para meus } \\
\text { alunos }\end{array}$ & $\begin{array}{c}\text { para a } \\
\text { sociedade } \\
\text { como um todo }\end{array}$ \\
\hline $\begin{array}{l}\text { Todos os } \\
\text { Respondentes }\end{array}$ & 3,54 & 3,43 & 3,41 \\
\hline Homens & 3,58 & 3,39 & 3,45 \\
\hline Mulheres & 3,52 & 3,46 & 3,38 \\
\hline $\begin{array}{l}\text { <30 Anos } \\
\text { 30-50 Anos }\end{array}$ & 3,67 & 3,57 & 3,43 \\
\hline$>50$ Anos & 3,50 & 3,39 & 3,39 \\
\hline $\begin{array}{l}\text { <5 anos de } \\
\text { experiência }\end{array}$ & 3,59 & 3,33 & 3,42 \\
\hline $\begin{array}{l}5 \text { a 15 anos de } \\
\text { experiência }\end{array}$ & 3,46 & 3,36 & 3,27 \\
\hline $\begin{array}{l}15 \text { a 20 anos de } \\
\text { experiência }\end{array}$ & 3,47 & 3,46 & 3,38 \\
\hline $\begin{array}{l}\text { Mais de 20 anos } \\
\text { de experiência }\end{array}$ & 3,67 & 3,44 & 3,42 \\
\hline
\end{tabular}

\begin{tabular}{|c|c|c|c|}
\hline $\begin{array}{c}1- \\
\text { irrelevantes }\end{array}$ & $\begin{array}{c}\text { 2- pouco } \\
\text { relevantes }\end{array}$ & $\begin{array}{c}\text { 3- relevantes } \\
\text { até certo ponto }\end{array}$ & $\begin{array}{c}\text { 4- muito } \\
\text { relevantes }\end{array}$ \\
\hline
\end{tabular}


A Tabela 33 apresenta o grau de compreensão dos professores em relação a quatro conceitos essenciais usados no estudo do futuro, a análise de tendências, a criação de futuros alternativos, teoria de sistemas e a consulta a especialistas. Em todas estas categorias, os índices de compreensão mostraramse dentro da faixa "tenho uma compreensão razoável". O último destes itens, a consulta a especialistas, parece ser aquele de mais fácil compreensão e assim, foi o que obteve as maiores médias (indicando maior compreensão) na maior parte dos estratos analisados, principalmente entre as mulheres, os respondentes com menos de 30 anos e aqueles com mais de 20 anos de experiência.

Em segundo lugar, temos a criação de futuros alternativos: apesar de não existirem diferenças marcantes entre as categorias, o conceito pareceu mais atraente em particular para os professores com menos de 30 anos e de graduação incompleta.

Os outros dois conceitos foram os que tiveram as menores médias entre toda a amostragem, com pequenas variações entre as diferentes categorias, e com uma pequena vantagem a favor da análise de tendências. Curiosamente, as menores médias encontradas, indicando o menor nível de compreensão (ainda que dentro da faixa de compreensão razoável) foram encontradas no grupo com nível de pós-graduação ou com mais de 20 anos de experiência profissional. Talvez por seu aspecto de maior complexidade, a teoria de sistemas foi 0 conceito cujos resultados apresentam menor nível de compreensão em relação aos outros, particularmente para os maiores de 50 anos. Os resultados dessa tabela parecem refletir o grau de complexidade envolvido no uso de tais conceitos: os dois que apresentam maior grau de compreensão seriam também aqueles que podem envolver o uso de ferramentas talvez percebidas como mais simples e menos "científicas" ou "teóricas" na visão dos professores. 
Tabela 33. "Baseado na apresentação, em relação aos conceitos envolvidos nos estudos do futuro, posso dizer que... ?"

\begin{tabular}{|l|c|c|c|c|}
\hline & $\begin{array}{c}\text { análise de } \\
\text { tendências }\end{array}$ & $\begin{array}{c}\text { criação de } \\
\text { futuros } \\
\text { alternativos }\end{array}$ & $\begin{array}{c}\text { teoria de } \\
\text { sistemas }\end{array}$ & $\begin{array}{c}\text { consulta a } \\
\text { especialistas }\end{array}$ \\
\hline Média Geral & 2,41 & 2,51 & 2,41 & 2,54 \\
\hline Homens & 2,48 & 2,45 & 2,39 & 2,42 \\
\hline Mulheres & 2,35 & 2,54 & 2,42 & 2,63 \\
\hline $\begin{array}{l}\text { <30 Anos } \\
\text { 30-50 Anos }\end{array}$ & 2,52 & 2,62 & 2,62 & 2,67 \\
\hline$>50$ Anos & 2,42 & 2,46 & 2,37 & 2,41 \\
\hline $\begin{array}{l}\text { Graduação } \\
\text { Completa }\end{array}$ & 2,48 & 2,50 & 2,17 & 2,83 \\
\hline $\begin{array}{l}\text { Graduação } \\
\text { Incompleta }\end{array}$ & 2,40 & 2,65 & 2,50 & 2,58 \\
\hline Pós Graduação & 2,31 & 2,42 & 2,19 & 2,55 \\
\hline & 2,33 & 2,44 & 2,28 & 2,50 \\
\hline $\begin{array}{l}\text { <5 anos de } \\
\text { experiência }\end{array}$ & 2,36 & 2,55 & 2,50 & 2,31 \\
\hline $\begin{array}{l}5 \text { a 15 anos de } \\
\text { experiência }\end{array}$ & 2,54 & 2,58 & 2,42 & 2,64 \\
\hline $\begin{array}{l}15 \text { a 20 anos de } \\
\text { experiência }\end{array}$ & 2,31 & 2,38 & & \\
\hline $\begin{array}{l}\text { Mais de 20 anos } \\
\text { de experiência }\end{array}$ & 2,33 & & & \\
\hline & & & & \\
\hline
\end{tabular}

\begin{tabular}{|c|c|c|}
\hline $\begin{array}{c}\text { 1- não compreendi } \\
\text { bem }\end{array}$ & $\begin{array}{c}\text { 2- tenho uma compreensão } \\
\text { razoável }\end{array}$ & $\begin{array}{c}\text { 3- tenho uma boa } \\
\text { compreensão }\end{array}$ \\
\hline
\end{tabular}


Como conseqüência, os resultados exibidos na Tabela 34, que mostra quais conceitos seriam particularmente benéficos para o aprendizado dos alunos do Ensino Médio, apresentam algumas semelhanças (a teoria de sistemas permanece como o conceito concebido como de menor beneficio para o aprendizado dos alunos entre os quatro), mas aqui surgem algumas diferenças interessantes: a análise de tendências tende a se equiparar (e em algumas categorias a suplantar, como no caso dos professores com mais de 20 anos de experiência) ao benefício percebido no aprendizado dos conceitos relacionados à criação de futuros alternativos e à consulta a especialistas. Outro dado interessante é que os professores com nível de pós-graduação formam o grupo que apontou os maiores graus de benefício no aprendizado dos três conceitos. Vale ressaltar ainda que todas as médias em todas as categorias estão na faixa que representa algum benefício percebido em seu aprendizado. Tais resultados sugerem que a preocupação com a preparação para o futuro dos jovens parece ser uma questão permanente ainda que não articulada de forma explícita. 
Tabela 34. "Baseado na apresentação, em relação ao aprendizado dos conceitos envolvidos nos estudos do futuro, posso dizer que meus alunos... ?"

\begin{tabular}{|c|c|c|c|c|}
\hline & $\begin{array}{l}\text { análise de } \\
\text { tendências }\end{array}$ & $\begin{array}{l}\text { criação de } \\
\text { futuros } \\
\text { alternativos }\end{array}$ & $\begin{array}{l}\text { teoria de } \\
\text { sistemas }\end{array}$ & $\begin{array}{c}\text { consulta a } \\
\text { especialistas }\end{array}$ \\
\hline Média Geral & 2,41 & 2,51 & 2,41 & 2,54 \\
\hline Homens & 2,60 & 2,70 & 2,57 & 2,67 \\
\hline Mulheres & 2,67 & 2,73 & 2,52 & 2,60 \\
\hline$<30$ Anos & 2,57 & 2,62 & 2,62 & 2,67 \\
\hline 30-50 Anos & 2,62 & 2,73 & 2,56 & 2,58 \\
\hline$>50$ Anos & 2,83 & 2,83 & 2,33 & 2,75 \\
\hline $\begin{array}{l}\text { Graduação } \\
\text { Completa }\end{array}$ & 2,59 & 2,66 & 2,63 & 2,47 \\
\hline $\begin{array}{l}\text { Graduação } \\
\text { Incompleta }\end{array}$ & 2,55 & 2,75 & 2,45 & 2,60 \\
\hline Pós Graduação & 2,77 & 2,77 & 2,50 & 2,85 \\
\hline $\begin{array}{lc}<5 & \text { anos } \\
\text { experiência } & \text { de }\end{array}$ & 2,50 & 2,59 & 2,50 & 2,59 \\
\hline $\begin{array}{l}5 \text { a } 15 \text { anos de } \\
\text { experiência }\end{array}$ & 2,52 & 2,76 & 2,48 & 2,60 \\
\hline $\begin{array}{l}15 \text { a } 20 \text { anos de } \\
\text { experiência }\end{array}$ & 2,69 & 2,69 & 2,62 & 2,54 \\
\hline $\begin{array}{l}\text { Mais de } 20 \text { anos } \\
\text { de experiência }\end{array}$ & 2,94 & 2,83 & 2,61 & 2,78 \\
\hline
\end{tabular}

\begin{tabular}{|c|c|c|}
\hline $\begin{array}{c}\text { 1- não se beneficiariam } \\
\text { muito }\end{array}$ & 2- teriam algum benefício & 3- se beneficiariam muito \\
\hline
\end{tabular}


As respostas da Tabela 35 ilustram o grau de relevância em relação aos métodos de pesquisa envolvidos nos estudos do futuro, que foram descritos na tipologia apresentada aos professores. A análise textual e de mídia e o uso de imaginação na elaboração de cenários foram os métodos com as médias indicando os maiores graus de relevância em seu aprendizado, particularmente entre os professores com nível de pós-graduação. O planejamento de ações aparece a seguir como o método de pesquisa mais relevante, ficando a análise quantitativa de tendências como o método percebido como menos relevante para o aprendizado dos alunos do Ensino Médio. Mais uma vez, a questão da possível dificuldade teórica relativa ao conteúdo parece ter afetado as decisões dos professores, que pareceram favorecer métodos que eles percebem como menos complexos. Apesar do alto grau de relevância demonstrado pelas médias das diferentes categorias, alguns resultados apresentam diferenças de interesse entre as diversas categorias. $O$ indicador demográfico relacionado ao número de anos experiência por exemplo, mostra que a relevância percebida em relação ao aprendizado de tais métodos aumenta à medida que o número de anos de experiência também aumenta. 
Tabela 35. "Como vê a relevância do aprendizado das seguintes habilidades por parte dos alunos do ensino médio?"

\begin{tabular}{|c|c|c|c|c|}
\hline & $\begin{array}{c}\text { análise } \\
\text { quantitativa de } \\
\text { tendências }\end{array}$ & $\begin{array}{c}\text { análise } \\
\text { textual e de } \\
\text { mídia }\end{array}$ & $\begin{array}{c}\text { uso da } \\
\text { imaginação } \\
\text { na } \\
\text { elaboração } \\
\text { de cenários } \\
\end{array}$ & planejamento de ações \\
\hline Média Geral & 1,72 & 1,49 & 1,47 & 1,53 \\
\hline Homens & 1,74 & 1,61 & 1,45 & 1,52 \\
\hline Mulheres & 1,71 & 1,42 & 1,48 & 1,54 \\
\hline$<30$ Anos & 1,57 & 1,57 & 1,52 & 1,52 \\
\hline 30-50 Anos & 1,78 & 1,43 & 1,43 & 1,50 \\
\hline$>50$ Anos & 1,75 & 1,58 & 1,50 & 1,67 \\
\hline $\begin{array}{l}\text { Graduação } \\
\text { Completa }\end{array}$ & 1,79 & 1,70 & 1,58 & 1,64 \\
\hline $\begin{array}{l}\text { Graduação } \\
\text { Incompleta }\end{array}$ & 1,85 & 1,50 & 1,55 & 1,60 \\
\hline Pós Graduação & 1,54 & 1,23 & 1,27 & 1,35 \\
\hline $\begin{array}{l}<5 \text { anos de } \\
\text { experiência }\end{array}$ & 1,59 & 1,36 & 1,55 & 1,50 \\
\hline $\begin{array}{l}5 \text { a } 15 \text { anos de } \\
\text { experiência }\end{array}$ & 1,96 & 1,69 & 1,65 & 1,77 \\
\hline $\begin{array}{l}15 \text { a } 20 \text { anos de } \\
\text { experiência }\end{array}$ & 1,54 & 1,46 & 1,31 & 1,38 \\
\hline $\begin{array}{l}\text { Mais de } 20 \text { anos } \\
\text { de experiência }\end{array}$ & 1,67 & 1,39 & 1,22 & 1,33 \\
\hline
\end{tabular}

\section{1- muita relevância}

2- alguma relevância
3- pouca relevância

4- sem relevância alguma 
A Tabela 36 também mostra que a análise textual e de mídia e o uso da imaginação na elaboração de cenários seriam, na visão dos professores pesquisados, os métodos pelos quais os alunos mais se interessariam, seguidos mais uma vez pelo planejamento de ações e por fim, pela análise quantitativa de tendências. Os grupos de professores mais experientes e aqueles com maior grau de formação são também aqueles que atribuíram as menores médias, aqui indicando o grau de interesse (entre "muito" e "algum" interesse, no caso) aos dois métodos preferidos, em contraste com as médias encontradas junto aos professores com nível de graduação incompleto e os professores mais jovens, que estão situadas na faixa "algum" e "pouco" interesse. Teríamos aqui talvez o caso da experiência como educador como fator preponderante, já que, à medida que o número de anos de experiência aumenta, também cresce o nível de interesse percebido (ou promovido) pelos professores em seus alunos pelo aprendizado das habilidades apresentadas. 
Tabela 36. "Como vê o interesse pelo aprendizado das seguintes habilidades por parte dos alunos do ensino médio?"

\begin{tabular}{|c|c|c|c|c|}
\hline & $\begin{array}{c}\text { análise } \\
\text { quantitativa } \\
\text { de } \\
\text { tendências }\end{array}$ & $\begin{array}{l}\text { análise } \\
\text { textual e } \\
\text { de mídia }\end{array}$ & $\begin{array}{c}\text { uso da } \\
\text { imaginação } \\
\text { na } \\
\text { elaboração } \\
\text { de cenários }\end{array}$ & $\begin{array}{c}\text { planejamento de } \\
\text { ações }\end{array}$ \\
\hline Média Geral & 2,25 & 1,96 & 1,94 & 2,22 \\
\hline Homens & 2,19 & 1,97 & 1,87 & 2,23 \\
\hline Mulheres & 2,29 & 1,96 & 1,98 & 2,21 \\
\hline$<30$ Anos & 2,33 & 2,29 & 2,10 & 2,43 \\
\hline 30-50 Anos & 2,24 & 1,93 & 1,91 & 2,13 \\
\hline$>50$ Anos & 2,17 & 1,50 & 1,75 & 2,17 \\
\hline $\begin{array}{l}\text { Graduação } \\
\text { Completa }\end{array}$ & 1,94 & 1,73 & 1,73 & 2,12 \\
\hline $\begin{array}{l}\text { Graduação } \\
\text { Incompleta }\end{array}$ & 2,75 & 2,40 & 2,35 & 2,70 \\
\hline Pós Graduação & 2,27 & 1,92 & 1,88 & 1,96 \\
\hline $\begin{array}{lr}<5 & \text { anos } \\
\text { experiência }\end{array}$ & 2,55 & 2,36 & 2,27 & 2,59 \\
\hline $\begin{array}{l}5 \text { a } 15 \text { anos de } \\
\text { experiência }\end{array}$ & 2,35 & 1,92 & 2,04 & 2,31 \\
\hline $\begin{array}{l}15 \text { a } 20 \text { anos de } \\
\text { experiência }\end{array}$ & 1,92 & 1,92 & 1,85 & 2,08 \\
\hline $\begin{array}{l}\text { Mais de } 20 \text { anos } \\
\text { de experiência }\end{array}$ & 2,00 & 1,56 & 1,44 & 1,72 \\
\hline
\end{tabular}


Os resultados da próxima tabela são de interesse particular para a pesquisa pois eles mostram o grau de dificuldade de introdução das diferentes atividades de sala de aula (crenças sobre o futuro, história improvável, criação de comunidades, metáforas sobre o futuro, ficção científica e pesquisas sobre sustentabilidade) envolvendo os estudos do futuro junto aos alunos do Ensino Médio. A Tabela 37 mostra que os professores do sexo masculino tendem a encarar o grau de dificuldade de introdução dessas atividades como maior do que as professoras respondentes. Não existiram variações muito grandes no que diz respeito à idade, mas sim, mais uma vez, no número de anos de experiência dos professores: quanto mais experientes, menos difícil para eles parece ser a introdução de tais atividades, a despeito de seu grau de formação. As atividades mais populares foram, nessa ordem, a ficção científica, a criação de comunidades e a história improvável. Mais uma vez, tais atividades podem parecer mais simples de serem introduzidas junto aos alunos devido à semelhança com outras atividades já realizadas pelos professores (ainda que estas não possuam necessariamente uma ótica explícita sobre o futuro). As atividades envolvendo metáforas e crenças sobre o futuro obtiveram resultados semelhantes em termos do grau de dificuldade de introdução, ficando atrás das três mencionadas. Por fim, as pesquisas sobre sustentabilidade são as atividades que os professores perceberam como mais difíceis de serem introduzidas em sala de aula, talvez por envolverem aspectos relacionados à análise de tendências e à teoria de sistemas (conceito já identificado anteriormente como "mais complexo" ou de "menor relevância"). 
Tabela 37. "Como julgaria o grau de dificuldade na introdução das seguintes atividades relacionadas aos estudos do futuro junto aos alunos do ensino médio?"

\begin{tabular}{|c|c|c|c|c|c|c|}
\hline & $\begin{array}{c}\text { crenças } \\
\text { sobre o } \\
\text { futuro }\end{array}$ & $\begin{array}{l}\text { história } \\
\text { improvável }\end{array}$ & $\begin{array}{l}\text { criação de } \\
\text { comunidade }\end{array}$ & $\begin{array}{c}\text { metáforas } \\
\text { sobre o } \\
\text { futuro }\end{array}$ & $\begin{array}{c}\text { ficção } \\
\text { científica }\end{array}$ & $\begin{array}{l}\text { pesquisas sobre } \\
\text { sustentabilidade }\end{array}$ \\
\hline Média Geral & 2,46 & 2,56 & 2,78 & 2,49 & 2,91 & 2,29 \\
\hline Homens & 2,29 & 2,48 & 2,71 & 2,32 & 2,87 & 2,45 \\
\hline Mulheres & 2,56 & 2,60 & 2,83 & 2,60 & 2,94 & 2,19 \\
\hline$<30$ Anos & 2,67 & 2,76 & 2,76 & 2,57 & 2,95 & 2,43 \\
\hline 30-50 Anos & 2,35 & 2,48 & 2,83 & 2,43 & 2,83 & 2,22 \\
\hline$>50$ Anos & 2,50 & 2,50 & 2,67 & 2,58 & 3,17 & 2,33 \\
\hline $\begin{array}{l}\text { Graduação } \\
\text { Completa }\end{array}$ & 2,47 & 2,55 & 2,74 & 2,51 & 2,89 & 2,30 \\
\hline $\begin{array}{l}\text { Graduação } \\
\text { Incompleta }\end{array}$ & 2,35 & 2,55 & 2,70 & 2,35 & 2,95 & 1,95 \\
\hline $\begin{array}{l}\text { Pós } \\
\text { Graduação }\end{array}$ & 2,35 & 2,38 & 2,69 & 2,31 & 2,81 & 2,27 \\
\hline $\begin{array}{l}<5 \text { anos de } \\
\text { experiência }\end{array}$ & 2,41 & 2,64 & 2,77 & 2,50 & 2,86 & 2,18 \\
\hline $\begin{array}{l}5 \text { a } 15 \text { anos } \\
\text { de } \\
\text { experiência }\end{array}$ & 2,54 & 2,58 & 2,73 & 2,46 & 2,81 & 2,35 \\
\hline $\begin{array}{l}15 \text { a } 20 \\
\text { anos de } \\
\text { experiência }\end{array}$ & 2,31 & 2,23 & 2,54 & 2,54 & 2,77 & 2,08 \\
\hline $\begin{array}{l}\text { Mais de } 20 \\
\text { anos de } \\
\text { experiência }\end{array}$ & 2,50 & 2,67 & 3,06 & 2,50 & 3,22 & 2,50 \\
\hline
\end{tabular}


As respostas da última pergunta do questionário (Tabela 38) usado nesta fase da investigação referem-se ao grau de preparação dos alunos do Ensino Médio para lidar com áreas de interesse particular para os estudos do futuro (questões globais, economia, política e governo, ciência e tecnologia), de acordo com a opinião dos professores. Segundo a opinião dos professores, os alunos do Ensino Médio parecem estar mais preparados para lidar com as questões e problemas encontradas na área envolvendo questões globais, particularmente na visão das mulheres e, mais uma vez, dos professores com maior número de anos de experiência. Tal área no entanto, apresenta resultados muito próximos nas outras categorias à área de ciência e tecnologia, sendo que esta última é vista como aquela para a qual os alunos estão mais preparados pelos professores com idade entre 30-50 anos e aqueles com graduação incompleta ou menos de 5 anos de experiência.

A preparação desses alunos para lidar com questões relacionadas á economia e à política e governo apresentam resultados bem inferiores em relação às duas mencionadas anteriormente. De acordo com as respostas, os alunos estariam ainda menos preparados para lidar com questões relativas à política e governo do que questões relacionadas à economia. Tal resultado poderia refletir mais uma visão de pouco compromisso por parte dos jovens em relação às questões políticas e governamentais do que um maior interesse ou conhecimento dos alunos de questões econômicas. De qualquer maneira, as questões globais e aquelas envolvendo ciência e tecnologia estão mais próximas à faixa de preparação "média" em contraste com a política e governo e a economia, que estão mais próximas à faixa de preparação "baixa". 
Tabela 38. "Na sua opinião, qual o grau de preparação dos alunos do ensino médio para lidar com as seguintes áreas de interesse relacionadas aos estudos do futuro?"

\begin{tabular}{|c|c|c|c|c|}
\hline & $\begin{array}{c}\text { QUESTÕES } \\
\text { GLOBAIS }\end{array}$ & ECONOMIA & $\begin{array}{l}\text { POLÍTICA E } \\
\text { GOVERNO }\end{array}$ & $\begin{array}{c}\text { CIÊNCIA E } \\
\text { TECNOLOGIA }\end{array}$ \\
\hline Média Geral & 2,22 & 2,55 & 2,69 & 2,23 \\
\hline Homens & 2,37 & 2,57 & 2,67 & 2,43 \\
\hline Mulheres & 2,13 & 2,53 & 2,70 & 2,11 \\
\hline$<30$ Anos & 2,25 & 2,60 & 2,75 & 2,35 \\
\hline 30-50 Anos & 2,31 & 2,60 & 2,73 & 2,20 \\
\hline$>50$ Anos & 1,83 & 2,25 & 2,42 & 2,17 \\
\hline $\begin{array}{l}\text { Graduação } \\
\text { Completa }\end{array}$ & 2,24 & 2,53 & 2,65 & 2,24 \\
\hline $\begin{array}{l}\text { Graduação } \\
\text { Incompleta }\end{array}$ & 2,25 & 2,70 & 2,75 & 2,15 \\
\hline Pós Graduação & 2,17 & 2,46 & 2,67 & 2,33 \\
\hline $\begin{array}{l}<5 \text { anos de } \\
\text { experiência }\end{array}$ & 2,27 & 2,59 & 2,73 & 2,18 \\
\hline $\begin{array}{l}5 \text { a } 15 \text { anos de } \\
\text { experiência }\end{array}$ & 2,50 & 2,67 & 2,83 & 2,42 \\
\hline $\begin{array}{l}15 \text { a } 20 \text { anos de } \\
\text { experiência }\end{array}$ & 2,00 & 2,46 & 2,54 & 2,00 \\
\hline $\begin{array}{l}\text { Mais de } 20 \text { anos } \\
\text { de experiência }\end{array}$ & 1,94 & 2,39 & 2,56 & 2,22 \\
\hline
\end{tabular}

\begin{tabular}{|l|l|l|l|}
\hline 1- alto & 2- médio & 3- baixo & 4- sem preparação \\
\hline
\end{tabular}




\subsection{ACOMPANHANDO A IMPLEMENTAÇÃO DE PROJETOS ENVOLVENDO OS ESTUDOS DO FUTURO NAS ESCOLAS- DISCUSSÃO DOS RESULTADOS}

Como já mencionado no início deste estudo, a pesquisa das atitudes de percepções dos professores em relação ao futuro e à implementação dos estudos do futuro junto a alunos do Ensino Médio não levaria necessariamente à implementação prática imediata de projetos ou abordagens dessa natureza nas escolas pesquisadas. Esperávamos, na verdade, que o interesse despertado pelo assunto levasse a algum tipo de implementação. Contudo, não poderíamos considerar a realização de tais atividades como condição essencial para a verificação das hipóteses levantadas, já que um processo de inovação curricular gerado pela apresentação da oficina ainda poderia percorrer diversos caminhos que estariam além do escopo deste trabalho.

No entanto, a oficina inspirou algumas iniciativas ainda no segundo semestre de 2007. A natureza de tais iniciativas reflete tanto as condições de trabalho dos diferentes professores como a estrutura curricular que adotam em suas escolas. Em alguns casos, elas tomaram a forma de atividades isoladas explorando as percepções dos alunos em relação à palavra "futuro". Em outros, representaram uma tentativa de inovação curricular mais estruturada, de forma a incluir diferentes atividades relacionadas aos estudos do futuro ao longo de diferentes anos anteriores ao Ensino Médio, sem, todavia deixar de incluir o trabalho com os alunos nesse nível. Um dos projetos, em particular, adotou a abordagem dos estudos do futuro a um projeto de natureza multidisciplinar já existente na escola e o estendeu através de outras atividades. Da forma planejada, simplesmente oferecemos ajuda aos professores e escolas nesse sentido, sem qualquer tipo de intervenção direta ou contato específico com os alunos envolvidos em tais projetos. Solicitamos apenas que os professores nos enviassem um relato do que foi feito, juntamente com quaisquer materiais utilizados, suas opiniões e outros documentos que acreditassem ser relevantes. 
Não nos cabe aqui, portanto, julgar a qualidade dos projetos em si ou mesmo se estes fizeram um uso ideal dos estudos do futuro e de suas ferramentas. O que nos parece relevante é que alguns dos professores, mesmo após uma única oficina de familiarização com tais ferramentas, foram motivados à experimentação com a nova abordagem ou, pelo menos à reflexão sobre a questão do futuro como um, talvez para alguns deles, novo paradigma no tratamento dos conteúdos. Naturalmente, uma perspectiva ideal de implementação exigiria uma familiarização maior dos profissionais de ensino envolvidos e uma estruturação da escola no sentido de criar as condições para tal processo. As iniciativas relatadas parecem mostrar que isso é possível. Esperamos que outras pesquisas explorem tais caminhos.

De qualquer forma, acreditamos que uma descrição dos projetos e atividades realizadas seria de interesse para futuras pesquisas, pois talvez apontaria caminhos para quais ferramentas podem se transformar em instrumentos de introdução dos estudos do futuro a curto prazo, ou mesmo até para oferecer uma referência na implementação de projetos semelhantes, através da seqüência de atividades, do tipo de reação dos professores e, naturalmente, no tipo de reação dos alunos. O relato das diferentes atividades e projetos, juntamente com opiniões colhidas junto aos alunos e professores sobre sua utilização compõe o conteúdo dos Anexos deste trabalho. 


\section{CONCLUSÕES E RECOMENDAÇÕES}

Os resultados das duas pesquisas revelam aspectos interessantes das concepções dos professores em relação ao futuro e, no caso da segunda pesquisa, à introdução de conceitos e abordagens relacionados ao ensino do futuro. Tais concepções podem não ter influência direta em sua atividade profissional, mas devem certamente afetar o modo como abordam sua prática profissional ou suas crenças como educadores.

Em geral, percebemos que os professores mostram uma rica diversidade em suas percepções e atitudes em relação ao futuro. Mais especificamente, os respondentes, tanto no caso do futuro em geral como do estudo do futuro, parecem interpretar a palavra "futuro" sobretudo dentro do contexto de suas próprias vidas e não da escola ou da sociedade.

O lugar desse futuro é, para a maioria, daqui a aproximadamente 10 ou 15 anos. Este é, sem dúvida, um período bem mais próximo daquele ao qual os estudiosos do futuro se referem. Além desse fato, os professores mostram que sua imagem do futuro vai perdendo a clareza daqui a 15 ou 20 anos, e os eles passam a pensar com pouca freqüência no futuro a partir desse ponto. Ao mesmo tempo em que tendem a exibir um alto grau de preocupação em relação ao futuro que desconhecem, os professores que responderam a pesquisa tendem a ser otimistas em sua maior parte, ainda que tal otimismo diminua à medida que os horizontes de tempo avancem.

De interesse particular para este trabalho, as respostas sugerem a crença em um alto grau de preparação para o futuro, mesmo para os períodos que não conseguem visualizar com clareza ou aqueles em que não parecem pensar muito a respeito (100 anos ou mais no futuro). Parece existir uma relação entre pensar mais sobre o futuro e a capacidade de imaginar o futuro e, portanto, tornar-se mais otimista em relação a ele. De um modo bastante semelhante à pesquisas 
realizadas com adolescentes em outros países mencionadas neste trabalho, tais resultados sugerem que a capacidade de explorar visões (através da criação de cenários, por exemplo), pode ser de valia para ajudar os professores a pensarem de modo mais positivo sobre o futuro e levá-los a iniciar um processo de ação nesse sentido (por exemplo, apoiando atividades de planejamento para períodos de tempo muito mais distantes do que aqueles normalmente usados pelos responsáveis por planejamento ou políticas nesse sentido).

Os resultados também sugerem que as representações de futuro dos indivíduos são também de natureza complexa e dependente do contexto onde estão inseridos. As implicações disto estão no fato de que estas representações diferem em termos de sexo, idade, formação acadêmica e religião. O grupo dos professores católicos tende a adotar um maior grau de preocupação do que os membros de outras religiões, por exemplo, assim como os professores mais jovens tendem a exibir maior otimismo (e também um maior grau de preocupação) com relação ao futuro. Cada uma destas diferenças merece exploração mais profunda em outras pesquisas.

Podemos concluir que mesmo em se tratando de um grupo com uma determinada característica em comum, professores de Ensino Médio, não deveríamos presumir que suas noções de futuro sejam semelhantes. Naturalmente, a pesquisa não foi desenhada para identificar falhas lógicas dos respondentes em suas idéias sobre o futuro ou mesmo sugerir que esses professores pensem de forma diversa dos profissionais dos estudos do futuro. Entretanto, é interessante notar que os professores acreditem ter maior controle sobre seus futuros individuais do que acreditam que a humanidade tenha sobre 0 destino dela, quando na verdade até mesmo o comportamento dos sistemas mais caóticos tende a ser mais previsível em larga escala do que ele o é por parte dos agentes que compõem o sistema.

O fato de que um pouco mais da metade da amostra acredita na extinção da humanidade, dentro de 500 anos ou mais, é, de certa forma, fonte de preocupação para os estudos do futuro. Tal fato se dá porque, na ausência de 
uma crença de que existirá um futuro, então poderíamos ver, conseqüentemente, uma menor inclinação para apoiar esforços para a proteção desse futuro, tanto para as gerações futuras como para um trabalho nesse sentido. Essa crença na extinção da humanidade sugere que mesmo o alto grau de preparação ativa para o futuro defendido pelos professores não seja suficiente para afastar esse destino. Estariam eles através dessas respostas expressando sua própria dificuldade em se preparar para o futuro e, nessa impotência, acreditando que o fim é inevitável? Pesquisas futuras deveriam certamente explorar essa contradição em maior detalhe.

No caso da segunda fase da pesquisa, podemos concluir que as ferramentas para o estudo do futuro que foram apresentadas durante a oficina podem, em certo grau, preencher esse "vazio" identificado na primeira fase. Corroborando essa afirmação estão as respostas indicando que os estudos do futuro são percebidos como de maior beneficio para os próprios professores e não necessariamente para seus alunos. Tal tendência pode tanto explicar que os professores desejam saber mais sobre seus futuros em particular (no que, talvez, não seriam diferentes de respondentes com outras profissões) antes de transmitirem seus conhecimentos nesse sentido. Isso pode revelar também um interesse de caráter pessoal, mas também de natureza profissional: para serem capazes de ensinar o futuro, os professores parecem antes querer aprender sobre ele. Isso sugere que a formação dos professores deva realmente conter elementos explícitos de preparação para estudar do futuro, caso tal abordagem realmente se torne um objetivo ativo da educação escolar.

Temos então a questão das diferentes ferramentas: aparentemente, quanto maior grau de preparação teórica necessária para o uso dessa ferramenta, menor parece ser a relevância ou o interesse da mesma ferramenta, segundo os professores, para os alunos por eles ensinados: estariam eles simplesmente expressando sua própria dificuldade na compreensão da ferramenta em si (e, portanto, sendo cautelosos em querer utilizá-la) ou seriam essa relevância e interesse baseados em seu conhecimento pessoal das 
capacidades dos alunos? Naturalmente, essas perguntas também merecem um aprofundamento maior em outras pesquisas.

Um dos elos de ligação entre as duas pesquisas é a maneira com a qual os professores vêem o papel do futuro na educação. Na primeira fase da pesquisa, a tendência apontada era de uma preparação pouco freqüente para o futuro, aliada a um baixo grau de preparação dos alunos nesse sentido. $\mathrm{Na}$ segunda fase, podemos notar que os professores afirmam abordar questões relacionadas ao futuro com uma freqüência um pouco maior do que na primeira fase. Estariam então os professores não enxergando o aspecto futuro das questões propostas ou simplesmente indicando que seu trabalho não inclui aspectos explícitos de uma abordagem voltada ao futuro?

Poderíamos então concluir que um desconhecimento dos aspectos mais formais dos estudos do futuro leve muitos dos professores a presumir que seu trabalho aborde tais questões. Enquanto a resposta parece ser verdadeira, a falta de uma ótica explícita parece na verdade impedir a criação do discurso futuro sugerido por Slaughter. Em outras palavras, mesmo o conhecimento sobre o futuro adquirido parece ainda ser expresso pelo paradigma passado-presente. $\mathrm{Na}$ verdade, uma das preocupações levantadas nas discussões com uma coordenadora, após a realização das duas fases da pesquisas, apontava exatamente para esse fato: segundo ela, seus alunos conseguiam identificar a problemática de uma situação, mas não exibiam o mesmo desembaraço em propor alternativas para o problema.

Voltamos aqui à questão das ferramentas, então: à maior parte das atividades sugeridas foi atribuído um grau de dificuldade médio ou baixo em termos de seu uso em sala de aula. Enquanto tais respostas poderiam sugerir uma rápida adoção destas em sala, tais ferramentas parecem também requerer uma mudança de paradigma por parte dos professores em sua utilização. Isso parece significar que o problema não está nas atividades em si, mas na familiaridade com o uso dela por parte do professor, que aqui se estenderia aos modos como ele interpreta o desenvolvimento desse discurso futuro. De fato, em 
um dos projetos realizados em uma das escolas, uma das dúvidas levantadas em relação ao uso de atividades envolvendo metáforas sobre o futuro criadas pelos alunos residia no fato dos professores desejarem saber qual seria a interpretação certa de cada uma dessas metáforas (ou mesmo se existiria uma metáfora ideal), e não necessariamente no processo de articulação e justificação da metáfora por parte do aluno e de como tal metáfora representaria a imagem criada pelo aluno para seu próprio futuro, que, na verdade, constituem o desenvolvimento desse discurso.

De qualquer forma, podemos concluir que a percepção dos professores em relação à introdução dos estudos do futuro junto a alunos do Ensino Médio tem mais aspectos positivos e negativos e que estes parecem conseguir identificar as ferramentas mais adequadas à sua prática educativa. Prova disso foi não só o número de experimentos realizados a partir de uma única oficina mas também a variedade de ferramentas utilizadas pelos professores em seus experimentos. Tal fato mostra que, de acordo com os preceitos sugeridos pelos PCNs, os professores parecem querer buscar novas abordagens em sala de aula e o estudo do futuro mostrou ser, nos experimentos relatados, uma alternativa viável de inovação curricular. Seriam então necessárias outras pesquisas que analisassem detalhadamente o processo de introdução de uma ou várias ferramentas em particular.

$\mathrm{Na}$ verdade, à medida que essa pesquisa se desenvolvia, seu caráter exploratório foi ficando ainda mais delineado. Conhecendo a escassez de pesquisas envolvendo o ensino do futuro no Brasil, nossa pesquisa buscou abordar o assunto de forma a propor o início de uma jornada nesse sentido. Porém, sabíamos desde o princípio que o território de exploração era vasto. Ainda assim, nos parecia necessário um mapeamento inicial que pudesse guiar essa exploração. Dessa forma, nosso trabalho procurou identificar e sintetizar os elementos principais que orientaram a construção desta pesquisa em particular: a importância histórica que o homem atribui a conhecer o futuro e que fez com que a disciplina tomasse forma no último século; as características do nosso sistema 
educacional (e em particular, do ensino secundário no país) em termos de mudanças de estrutura curricular; a natureza e os processos que podem levar às inovações do currículo; e as diferentes maneiras através das quais o futuro é ensinado em programas escolares. No entanto, o levantamento bibliográfico feito para cada uma das áreas principais, os estudos do futuro, a educação brasileira e a inovação curricular e o ensino do futuro, mostra que há diversas hipóteses a serem levantadas e exploradas por pesquisas em cada uma dessas áreas, isoladamente.

De uma forma condizente então com os conceitos relacionados aos estudos do futuro discutidos neste trabalho e, em particular, com o conceito de elaboração de cenários apresentado aqui, apontamos agora algumas alternativas para pesquisas futuras nessa área.

Em um cenário provável, poderíamos sugerir pesquisas que abordassem individualmente e em maior profundidade as grandes áreas acima mencionadas, como por exemplo, uma discussão mais extensa da natureza dos estudos do futuro, dentro de uma perspectiva particularmente brasileira. Ainda, abordar a educação brasileira, de modo a identificar as razões pelas quais as recomendações dos $\mathrm{PCNs}$ e seu trabalho multidisciplinar com temas transversais ainda parecem se encontrar em seus primeiros estágios nas escolas. Por fim, utilizar outras amostragens ou outros instrumentos para explorar mais profundamente as percepções de futuro dos professores brasileiros, e de que maneira estas afetam a adoção de novas abordagens em sala de aula.

Em um cenário possível, efetuar outros experimentos e o acompanhamento de uma proposta curricular com abordagem voltada ao futuro criada junto a uma escola, de maneira a obter um melhor controle sobre as variáveis envolvidas na introdução de tal abordagem. Em escala maior, analisar de que forma os sistemas escolares mostram-se mais ou menos resistentes às inovações propostas pelos PCNs, por exemplo, e quais seriam as alternativas para efetuar as mudanças desejadas para vencer tais resistências. E, por extensão, realizar pesquisas sobre as percepções de futuro dos jovens 
brasileiros, para que também disponhamos de dados nesse sentido e para que estas possam orientar mudanças e inovações na educação brasileira.

Em um cenário desejável, utilizar os estudos do futuro para propor cenários distintos para a educação brasileira e a partir daí, planejar ações que levem à concretização de uma visão coletiva para a melhoria da educação e da sociedade brasileira. Acreditamos que se esta perspectiva futura for utilizada como elemento de análise e reflexão da educação brasileira, as opções apresentadas poderão realmente contemplar não só o futuro da educação, mas também a educação para o futuro. 


\section{REFERÊNCIAS BIBLIOGRÁFICAS}

ANTUNHA, Heládio C. G. A Educação Brasileira no Período Republicano. in BREJON, Moyses (org.). Estrutura e Funcionamento do Ensino de $1^{\circ}$ e $2^{\circ}$ graus. São Paulo. Pioneira. 1973

ANTUNHA, Heládio C.G. Universidade de São Paulo: Fundação e Reforma. São Paulo. CRPE. 1974. p.53, nota 1

ARON, Raymond . The Dawn of Universal History. New York. Praeger . 1961

BEISEGEL, Celso de Rui. Educação e sociedade no Brasil após 1930. in: FAUSTO, B. (org.). História Geral da Civilização Brasileira. DIFEL. 1984. tomo III, v.4. p.395.

BELL, Wendell. An Overview of Future Studies, Knowledge Base of Future Studies/ art113.htm. CD-ROM. 2005

BELL, Wendell . Foundations of Futures Studies: Human Science for a New Era. vol. 1, 'History, purposes and knowledge' and vol. 2, 'Values, objectivity and the good society'. Transaction Pubs. New Brunswick. NJ. 1996

BERTALANFFY, Ludwig Von. Teoria Geral dos Sistemas. Ed. Vozes. 1975. 
BOARD OF SENIOR SECONDARY SCHOOL STUDIES, Pre-Pilot Senior Syllabus in Futures, Brisbane. 1999.

BOLIVAR, A. Cómo mejorar los centros educativos. Madrid. España. Síntesis Educación. 2002

BOULDING, Elise, Reflections On The Work Of Fred Polak, Alternative Futures 2 (Summer 1979)

BOULDING, E.. Building a Global Civic Culture: Education for an Interdependent World, Syracuse University Press. 1990

BREJON, Moyses (org.). Estrutura e Funcionamento do Ensino de $1^{\circ}$ e $2^{\circ}$ graus. São Paulo. Pioneira. 1973

BYRNE, John; INGERSOLL, David e RICH, Daniel. Governing Utopia: The Challenge to Political Visions Alternative Futures 4 (Winter 1981),

CAPANEMA, Gustavo . Exposição de motivos da lei orgânica do ensino secundário. s.d. in PILETTI, Nelson. História da Educação no Brasil. Série Educação. Editora Ática. 7 ed. 2006 pp.95-96

CARVALHO, Laerte Ramos de. As reformas pombalinas da instrução pública. São Paulo. Saraiva/Edusp. 1978. 
CHAGAS, Valnir. Educação Brasileira: o ensino de $1^{\circ}$ e $2^{\circ}$ graus. 2 ed. São Paulo. Saraiva. 1980

CORNISH, Edward et al. The Study of the Future: An Introduction to the Art and Science of Understanding and Shaping Tomorrow's World. Washington. D.C. World Future Society, 1977, Appendix B

COURMAN, Andre e LEVY, Maurice (eds.), Shaping the Future. New York: Gordon \& Breach, 1973

Indução em CRONOLOGIA DAS CIVILIZAÇÕES, Editora Abril, 1979 São Paulo

DICCIONARIO DE LAS CIÊNCIAS DE LA EDUCACIÓN. Madrid. Santillana. 1988. p.1223

DICIONÁRIO HOUAISS. Editora Objetiva .Rio de Janeiro. 2001. 1ª ed.

DIDSBURY, Howard Prep 21 Course Guide (Washington: World Future Society, 1986). In HICKS, David e SLAUGHTER, Richard A. (eds). Futures Education. World Yearbook of Education 1998. London: Kogan Page, 1998

ESCOLA DO FUTURO, http://www.futuro.usp.br/ Acesso em 12 jun 2007

ESCUDERO Muñoz J. M. La innovacón y la organización escolar .... In JORGE, Leila. Inovação Curricular. Além da Mudança dos Conteúdos. São Paulo. UNIMEP. 1996. p. 86 
EVENSON, Simon. How to see the future. Focus. Nov./2004. pp. 22-28.

FARRELL, Edmund J. Deciding the future: A forecast of the responsibilities of secondary school teachers of English, 1970-2000 A.D. Urbana, III: National Council of Teachers of English, NCTE \#12 , 1972

FAUSTO, B. (org.), História Geral da Civilização Brasileira.DIFEL, tomo III, 1984.

FIEN, J.. Teaching and Learning for a Sustainable Future, UNESCO. 2002.

FLECHTHEIM, Ossip. History and futurology. Veriag Anton Haim, 1966.

FUTURE PROBLEM SOLVING, http://www.fpspi.org/, Acesso em 2 ago 2007

GALTUNG, J. (1982). Schooling, Education and the Future. Malmo, Sweden, Department of Education and Psychology Research, Lund University. BJERSTEDT, A. (1982). Future Consciousness and the School. Malmo, School of Education, University of Lund, Sweden. In GIDLEY, Jennifer Futures/Foresight in Education at Primary and Secondary Levels: A Literature Review and Research Task Analysis. Monograph Series 2004. No. 5. Australian Foresight Institute Swinburne University

GARRETT, Peter. Toppling the House of Cards. In: HEADON, D. Editor, Looking Beyond Yesterday, Oxford University Press, Melbourne 1990, pp. 39-43. 
GIDLEY, Jennifer. Prospective youth visions through imaginative education. Futures 30 (5) 1998 pp.395-408

GIDLEY, Jennifer \& INAYATULLAH, Sohail. eds. Youth Futures: Comparative Research and Transformative Visions, Westport CT: Praeger. 2002

GIDLEY, Jennifer Futures/Foresight in Education at Primary and Secondary Levels: A Literature Review and Research Task Analysis. Monograph Series 2004. No. 5. Australian Foresight Institute Swinburne University

GIL, Antonio Carlos. Métodos e técnicas de pesquisa social / Antonio Carlos Gil. - 5.ed. - São Paulo : Atlas, 1999

GONZALEZ, M. T. e ESCUDERO MUÑOZ, J. M. Innovación educativa: teoria y processos de desarrollo. Barcelona. Humanitas. 1987

GOUGH, N. 'Futures in Australian Education: Tacit, Token and Taken for Granted Futures.' Futures April, 1990. pp298-310

HAIDAR, Maria de L.M. O Ensino Secundário no Império Brasileiro. São Paulo. Grijalbo. 1972.

HALLEY, Richard B. e VATTER, Harold G. Technology and the Future as History: A critical review of futurism, Technology and Culture 19. (January 1988). pp.53-82 
HEADON, D. Editor, Looking Beyond Yesterday, Oxford University Press, Melbourne 1990

HICKS, David e HOLDEN, Cathy . Visions of the Future: Why we Need to Teach for Tomorrow, London: Trentham Books, 1995.

HICKS, David. A lesson for the future: Young people's hopes and fears for tomorrow. Futures 28 (1). 1996

HICKS, David e SLAUGHTER, Richard A. (eds). Futures Education. World Yearbook of Education 1998. London: Kogan Page, 1998

HICKS, David. Envisioning the Future: The challenge for environmental educators, Futures, 28 (1) 2000. pp1-13

HICKS, David. Citizenship for the Future: A Practical Classroom Guide. Godalming, World Wide Fund for Nature UK, 2001

HICKS, David. Lessons for the future: the Missing Dimension in Education. Victoria, Routledge Farmer. 2002

HUBERMAN, A. M. Como se realizam as mudanças em educação: subsídios para o estudo do problema da inovação. Tradução de Jamir Martins. São Paulo: Cultrix, 1976. (publicado pela Unesco em 1973) 
HUMMEL, C. La educación hoy frente el mundo del mañana. Caracas. Voluntad. 1988

IBGE. (Instituto Brasileiro de Geografia e Estatística) ,www.ibge.gov.br, Acesso em Novembro de 2007

INAYATULLAH, Sohail. Methods and Epistemologies in Futures Studies. Knowledge Base of Future Studies/ art. 142.htm. CD-ROM. 2005

INAYATULLAH, S e WILDMAN, P. Futures Studies: Methods, Emerging Issues and Civilizational Visions. A Multi-Media CD ROM. 1998

JACKSON, Cole. Learning with an active voice: children and youth creating preferred futures, Cap, 16 in: GIDLEY, J \& INAYATULLAH, S. eds. Youth Futures: Comparative Research and Transformative Visions, Westport CT: Praeger. 2002

JOHNSON, L. Children's visions of the future. The Futurist: 1987, pp.36-40

JONES, Thomas. E. The Futurist Movement: A Brief History. World Future Society Bullettin 13 (July-August,1979). pp.13-26

JORGE, Leila. Inovação Curricular. Além da Mudança dos Conteúdos. São Paulo. UNIMEP. 1996 
JUNGK, Robert. Brighter than a Thousand Suns. New York. Harcourt, Brace \& World. 1958 in NORRIS, Neal A. Educating Toward Tomorrow: A Rationale for Introducing Futurism into the Secondary School Social Studies Curriculum. PhD Dissertation. University of Massachusetts, 1983

KAHANE, Adam. Civic Scenarios as a Tool for Societal Change. Journal of Strategy \& Leadership (Vol. 30 Issue. 1). pp: 32 - 37, MCB UP Ltd. 2002

KAUFFMAN, Jr. Draper L. Teaching the future: A Guide to Future Oriented Education. ETC. Palm Springs.1976

KAUFFMAN, Jr. Draper L. Futurism and Future Studies. National education Association. Washington. 1976

THE LANCASTERIAN MONITORIAL SYSTEM OF EDUCATION:

http://www.constitution.org/lanc/monitorial.htm, Acesso em 23 ago 2007.

LEI DE DIRETRIZES E BASES DA EDUCAÇÃO NACIONAL, № 9394, DE 20/12/96 in PILETTI, Nelson. Estrutura e funcionamento do ensino fundamental. Ed. Ática. São Paulo. 2004.

LABORATÓRIO DE ESTUDOS DO FUTURO.

http://www.unb.br/administracao/reitoria/lef.php, 2007 Acesso em 12 ago 2007

LITTO, Fredric. Para que serve a escola. Pátio, São Paulo, n.3, nov. 1997 
LITTO, Fredric M. A Universidade e o Futuro do Planeta, in A Universidade em Questão. Ethevaldo SIQUEIRA, (org.) 2015-Como Viveremos. São Paulo: TeleQuest, 2004, pp. 212-218.

LOURENÇO FILHO, Manuel B. Introdução ao Estudo da Escola Nova. 7.ed. São Paulo. Melhoramentos. s.d.

LUKACS, John. The Passing of the Modern Age. New York. Harper \& Row. 1970

MACK, Tim (ed) Hopes and visions for the $21^{\text {st }}$ century. World Future Society Bethesda EUA 2005.

MARIEN, Michael. Who Coined the Post-Industrial Society? The Futurist 7, 1973, pp. 268-69

MCDANIEL, Michael. Leaning for tomorrow. Tomorrow Curriculum Today. 1980

MCFAUL, Thomas R. Religion in the Future Global Civilization. The Futurist. September- October 2006

MORRISH, I. Cambio e innovación en la enseñanza. Salamanca. España. Anaya. 1978

MORROW, Rowena. Images of a Sustainable Primary School, in: MACK, Tim (ed) Hopes and visions for the $21^{\text {st }}$ century. World Future Society Bethesda EUA, 
2005. pp.307-320

MUSGRAVE, Alan. Common Sense, Science and Scepticism. Cambridge University Press. Cambridge. 1993

NICHOLSON, Simon e LORENZO, Ray. "Future Perfect", Undercurrents 36 (1979): 12-14. Montclair Public School Brochure, Montclair, New Jersey (1980).

NORRIS, Neal A. Educating Toward Tomorrow: A Rationale for Introducing Futurism into the Secondary School Social Studies Curriculum. PhD Dissertation. University of Massachusetts. 1983

Indução: In: NOSSO SÉCULO. Abril Cultural. São Paulo. 1980

NÚCLEO DE ESTUDOS DO FUTURO PUC-SP http://www.nef.org.br/index.cfm, Acesso em 13 jun 2007

PAGE, Jane Reframing the Early Childhood Curriculum - Educational Imperatives for the Future, London: Routlege/Falmer, 2000.

PARÂMETROS CURRICULARES NACIONAIS.

http://portal.mec.gov.br/seb/arquivos/pdf/livro01.pdf. Acesso em 11 nov 2007

PILETTI, Nelson. A reforma Fernando de Azevedo, 1927-1930. São Paulo. Feusp. 1982

PILETTI, Nelson. História da Educação no Brasil. Série Educação. Editora Ática. 
7 ed. 2006

POLAK, Fred L. Prognostics: A Science in the Making Surveys the Future. Amsterdam, The Netherlands Elsevier Publishing Co. 1971

POLAK, Fred. L. The image of the future. Elise Boulding (trad). San Francisco. Josey Bass. 1973

POSTMAN, Neil e WEINGARTER, Charles. Teaching as a subversive activity, New York, Dell Publishing Co, 1969 pp. xxiii-xiv

PROGRAMA DE ESTUDOS DO FUTURO- FIA- USP.

http://www.fundacaofia.com.br/profuturo/. Acesso em 13 jun 2007

REICHENBACH, Hans. The Rise of Scientific Philosophy. University of California Press. Berkeley, CA. p.241. 1951

ROGERS, M. (1998). Student Responses to Learning about the Future. World Yearbook of Education 1998: Futures Education. D. Hicks and R. Slaughter. London, Kogan Page.

ROGERS, E.M. e AGARWALA-ROGERS, R. Communication in Organizations. The Free Press. USA. 1976

SAUL, John. The Unconscious Civilisation. London, Penguin, 1997 
SCHULTZ, W. Defining Futures Fluency. In INAYATULLAH, S e WILDMAN, P. Futures Studies: Methods, Emerging Issues and Civilizational Visions. A MultiMedia CD ROM. Brisbane, Prosperity Press. 1998

SHANE, Harold. The Educational Significance of the Future. The Futurist 7. June 1973

SLAUGHTER, Richard A. From Fatalism to Foresight - Educating for the Early $21^{\text {st }}$ Century: A framework for considering young people's needs and responsibilities over the next 20 years. Melbourne. Australian Council for Educational Administration. 1994.

SLAUGHTER, Richard A. Futures Tools and Techniques. Melbourne. Futures Studies Centre. 1995

SLAUGHTER, Richard A. The Foresight Principle. New York. Routledge Falmer. 1995

SLAUGHTER, Richard A. The Knowledge Base of Futures Studies. 1998 p.51-60. In HICKS, David e SLAUGHTER, Richard A. (eds). Futures Education. World Yearbook of Education 1998. London. Kogan Page. 1998

SLAUGHTER, Richard A. From Rhetoric to Reality: The Emergence of Futures into the Educational Mainstream. 2002 
SLAUGHTER, Richard A. Futures Beyond Dystopia. New York. Routledge Falmer. 2003

SLAUGHTER, Richard A. Futures Concepts. Vol. 1, art. 213.htm.Knowledge Base of Future Studies/. CD-ROM. 2005

TEIXEIRA, Anísio. Valores proclamados e valores reais nas instituições escolares brasileiras. Revista Brasileira de Estudos Pedagógicos, v 37. n.86. abr/jun. 1962. p.59

TOFFLER, Alvin. The Futurists. Random House. 1972

TOFFLER, Alvin. Learning for Tomorrow: the Role of the Future in Education. Vintage Books USA. 1974

TONN, Bruce; CONRAD,Fred; HEMRICK, Angela. Cognitive Representations Of The Future: Survey Results. Paper. 10/21/04 University of Tennessee, Knoxville, University of Michigan

TORRES, Rosa María. Sistema escolar y cambio educativo: repasando la agenda y los actores. 2003. www.fronesis.org. Acesso em 23 jun 2007

WELLS, H.G. The Discovery of the Future, Nature 65 (February 6, 1902). pp.327329 
WELLS, H.G. The Outline of History, Doubleday 1949

WELLS, H.G. "Wanted: Professors of Foresight!", Futures Research Quarterly, $3: 1,89-91,1987$

WELLS, H.G. The Last Books of H.G. Wells: The Happy Turning \& Mind at the End of Its Tether. Monkfish, 2006 


\section{BIBLIOGRAFIA ADICIONAL}

AMARA, Roy. What we have learned about forecasting and planning. Futures. August 1988.

APPLE, M. W. What reform talk does: creating new inequalities in education. Educational Administration Quartely, 24(3), pp. 272-81. 1988.

BABIN, Pierre, KOULOUMJJIAN, Marie-France. Os novos modos de compreender. São Paulo. Paulinas. 1989.

BELL, W e MAU, J. A. (eds.). The Sociology of the Future. Russell Sage Foundation. New York. 1971.

BORTONINI, Armando \& SOUSA, Valdemarina (org). Mediação Tecnológica. Porto Alegre. EDIPOUCRS. 2004

BOULDING, Elise. BOULDING, Kenneth E. The Future: Images and Processes. Sage Publications. 1994

BOWER, J. L. and CHRISTENSEN, C.M. Como pegar a onda do futuro. Revista Exame. 10 de maio de 1995.

BRAGA, José Luiz e CALAZANS, Regina. Comunicação \& Educação. Questões delicadas na interface. São Paulo. Hacker editors. 2001. 14-70 CENECA. 
BROWN, H. Douglas. Teaching by Principles. Prentice Hall.1994.

BRUNER, J. O processo da educação. São Paulo. Nacional. 1968.

CANDLIN, C. Towards task-based learning. OUP.1987.

CARBONELL, Jaume. A aventura de inovar: a mudança na escola. Tradução de Fátima Murad. Porto Alegre. Artmed. 2002.

CARDOSO, Fernando Henrique. Mudanças sociais na América Latina. São Paulo. Difusão Européia do Livro. 1969.

CASTRO, Cláudio de Moura. Ponto de vista. Veja, São Paulo. Ed. Abril, № 1697. abril /2001.

CITELLI, Adilson. Aprender e ensinar com textos não escolares. São Paulo. Cortez. 1997.

COATES, Joseph F. Technology Assessment: The Benefits, the Costs, the Consequences. The Futurist. December. 1991.

CORNISH, Edward (Ed.). Exploring your future. Living, learning, and working in the information age. World Future Society. Bethesda, Maryland, USA. 1998. 
DALIN, P. Stratégies d'innovation dans l'enseignement. In: Organization de Coopérationet de Développement Économiques. Centre Pour La Recherche Et L'Innovation Dans L'Esnseignement. Études de cas d'innovation dans l'enseigement. v. IV. Paris. 1973.

DREYFUS, Hubert L. On the Internet. New York. Roudledge. 2001.

DUBIN, F and OLSHTAIN, E. Course Design. CUP 1994.

EISENSTADT, S.N. Modernização: protesto e mudança de sociedades tradicionais Tradução de José Gurjão Neto. Rio de Janeiro. Zahar. 1969.

FERNANDES, Florestan. Mudanças sociais no Brasil: aspectos do desenvolvimento da sociedade brasileira. São Paulo. Difusão Européia do Livro. 1960.

FERRETTI, C. J. A inovação na perspectiva pedagógica. In: GARCIA, W. E. (Coord.). Inovação educacional no Brasil: problemas e perspectivas. São Paulo. Cortez. Autores Associados. 1980

FREIRE, Paulo. Educação e mudança. 26. ed. Rio de Janeiro. Paz e Terra. 1979.

FREIRE, Paulo. Pedagogia do oprimido. $2^{\mathrm{a}}$ ed. Rio de Janeiro. Paz e Terra. 1975. 54 
FULLAN, M. G., STIEGELBAUER, S. The new meaning of educational change. 2. ed. Londres. Cassell. 1992. p. 401.

GARCIA, Edson Gabriel. Comunicação e Educação: Campos e relações interdisciplinares. http://www.eca.usp.br/nucleos/nce/perfil edson.html . Acessado em 25.05.2007.

GARCIA, P. B. Educação: modernização ou dependência? Rio de Janeiro. Francisco Alves. 1977.

GARCIA, W. E. (Coord.). Inovação educacional no Brasil: problemas e perspectivas. São Paulo. Cortez. Autores Associados. 1980.

GARDNER, Howard. Inteligência: um conceito reformulado. São Paulo. Objetiva. 2000.

GERSHENFELD, Neil. When things start to think. New york. Hernry Holt and Company. 1999.

GIDDENS, Anthony. As conseqüências da modernidade. Tradução de Raul Fiker. São Paulo. Unesp. 1991.

GODET, Michel. Scenarios and Strategic Management. Butterworths Scientific Ltd. 1987. 
GOLDBERG, M. A. Inovação educacional: a saga de sua definição. In: GARCIA, W. E. (Coord.). Inovação educacional no Brasil: problemas e perspectivas. São Paulo. Cortez. Autores Associados. 1980. pp. 183-194.

GOLDBERG, M. A. Inovação educacional: grandezas e misérias da ideologia. In: GARCIA, W. E. (Coord.). Inovação educacional no Brasil: problemas e perspectivas. São Paulo. Cortez. Autores Associados. 1980. pp. 235-243.

GUTIERREZ, Francisco \& PRIETO, Daniel. A Mediação Pedagógica. SP. Papirus. 1994.

HALLES, N. Katherine. How we became posthuman. Chicago. The University of Chicago Press. 1999.

HAVELOCK, R. G., HUBERMAN, A. AM. Innovation et problèmes de l'education: théorie et réalité dans lês pays em éveloppement. Paris. Unesco. 1980.

HENCLEY, Stephen P., YATES, James R. Futurism in education: Methodologies. McCutchan Publishing Corporation. 2526 Grove Street, Berkeley, California 94704. 1974.

JOHNSON, B.B., MARCOVITCH, Jacques. Uses and Applications of Technology Futures in National Development: the Brazilian Experience. Technological Forecasting and Social Change n45 pp.1-30.1994. 
KILPATRICK, William Heard. Educação para uma civilização em mudança. $4^{\underline{a}}$ ed. Tradução de Noemy S. Rudolfer. São Paulo. Melhoramentos. 1964. [1 $1^{a}$ ed. de 1932].

LITTO, F. M. A nova ecologia do conhecimento: conteúdo aberto, aprendizagem e desenvolvimento. Inclusão Social, v.01 pp. 73-78. 2006.

LITTO, F. M. Aprendizagem a toda hora e em todo lugar. In: Ethevaldo Siqueira. (Org.). Perspectivas da Sociedade da Informação no Brasil. 1ํㅡ ed. São Paulo. Telefônica. 2006. v. 01, pp. 182-199.

LITTO, F. M. Formação Específica Não Prepara o Estudante. Folha de São Paulo. São Paulo. 27 Abr. 1986.

LITTO, F. M. O Trabalho Colaborativo e o Futuro da Sociedade Brasileira. In: Mauricio Garcia. (Org.). Gestão Profissional em Instituições Privadas de Ensino Superior. $1^{a}$ ed. Vila Velha . ES. Hoper. 2006. v. 01, pp. 181-186.

LITTO, F. M. Perspectivas da Educação a Distância no Brasil: Três Cenários a Ponderar [1997-2002]. Revista Brasileira de Aprendizagem Aberta e a Distância. São Paulo. v. 2, nº 3. 2003.

LITTO, F. M. Repensando a educação em função de mudanças sociais e tecnologias recentes. In: OLIVEIRA, Vera Barros. (Org.). Informática em psicopedagogia. São Paulo. Senac. 1996. pp. 85-110. 
LITTO, F. M. Um modelo para prioridades educacionais numa sociedade de informação. Revista Pátio. Revista Pedagógica. Porto Alegre. v. 1, oo 3, pp. 1421. 1998.

MARTINO, Joseph P. Technological Forecasting for Decision Making. McGrawHill. 1993.

MINISTÉRIO DA EDUCAÇÃO E CULTURA. DEPARTAMENTO DE ENSINO MÉDIO \& FUNDAÇÃO CARLOS CHAGAS. DEPARTAMENTO DE PESQUISAS EDUCACIONAIS. Inovação educacional: mapeamento bibliográfico. São Paulo. 1978.

MOREIRA, J. Roberto. Hipóteses e diretrizes para o estudo das resistências à mudança social, tendo em vista a educação e a instrução pública como condições ou fatores. Curitiba. Associação de Estudos Pedagógicos. 1959.

MORRISON, James L., RENFRO, William L., BOUCHER, Wayne I. (Eds.). Applying Methods and Techniques of Futures Research. New Directions for Institutional Research, no 39, Volume X. number 3. San Francisco. Jossey Bass. 1983.

NOT, Louis. Ensinando a aprender: elementos de psicodidática geral. São Paulo. Summus. 1993.

NUNAN, David. Syllabus Design. OUP. 1991. 
PILETTI, Claudino. Filosofia da educação. Ed. Ática. São Paulo. 2005.

PORTER, Michael E. Vantagem Competitiva. Cap. 13 - Cenários Industriais e Estratégia Competitiva sob Incerteza. Editora Campus. 1989.

ROSSETTI, Fernando. Projetos de Educação, Comunicação \& Participação Perspectivas para Políticas Públicas. (http://rossetti.sites.uol.com.br). Acessado em 26.05.2007

SAVIANI, D. A filosofia da educação e o problema da inovação em educação. In: GARCIA, W. E. (Coord.). Inovação educacional no Brasil: problemas e perspectivas. São Paulo. Cortez. Autores Associados. 1980. pp. 15-29.

SCHWARTZ, Peter. The Art of the Long View. Doubleday. 1991.

SEVERINO, Antônio Joaquim (1941). Metodologia do trabalho científico. $22^{a}$ ed. rev. e ampl. de acordo com a ABNT. São Paulo. Cortez. 2002.

SOARES, Ismar de Oliveira. A 'Era da Informação: tecnologias da comunicação criam novas relações culturais e desafiam antigos e novos educadores. In Tecnologia Educacional. ABT. Rio de Janeiro, 22 (113-114): 11-19. Jul./Out. 1993.

SOARES, Ismar de Oliveira. Manifiesto de la Educación para la comunicación en los paises en vias de Desarrollo. La Coruña. Espanha. 1955. 
TEDESCO, Juán Carlos, TORRES, Rosa María. A modo de síntesis del foro. In: TORRES, Rosa María (Org.). Gestión de la transformación educativa: requerimientos de aprendizaje para las instituciones. Buenos Aires. IIPE-Unesco. 1999. pp. 8-10.

THOMAS, Charles W. Learning from Imagining the Years Ahead. Planning Review. May/June 1994

TORRES, Rosa María (Org.). Gestión de la transformación educativa: requerimientos de aprendizaje para las instituciones. Buenos Aires. IIPE-Unesco. 1999.

WANDERLEY, L. E. W. Parâmetros sociológicos da inovação. In: GARCIA, W. E. (Coord.). Inovação educacional no Brasil: problemas e perspectivas. São Paulo. Cortez. Autores Associados. 1980. pp. 30-54.

WARDE, M. J., RIBEIRO, M. L. S. O contexto histórico da inovação educacional no Brasil. In: GARCIA, W. E. (Coord.). Inovação educacional no Brasil: problemas e perspectivas. São Paulo. Cortez. Autores Associados. 1980. pp. 195-204.

WILLS, G. Technological Forecasting. Pelican Library of Business and Management. Penguin Books. 1972. 